Pétervári Máté

A járások kialakítása Magyarországon

az 1870: XLII. tc. alapján 



\section{Pétervári Máté}

\section{A járások kialakitása Magyarországon az 1870:XLII. tc. alapján}

Szegedi Tudományegyetem, Állam- és Jogtudományi Kar Szeged, 2021 
A monográfia a szerző 2018. november 7-én megvédett A járások kialakítása Magyarországon az 1870:XLII. tc. alapján címü doktori értekezésén alapul.

Lektor:

(....Homoki-Nagy Mária??)

Szabó István

A kézirat lezárva:

2021. március 10.

A jelen könyv kiadása az Igazságügyi Minisztérium jogászképzés színvonalának emelését célzó programjai keretében valósult meg.

A kiadó számára minden jog fenntartva. A jelen könyvet, illetve annak részleteit tilos a kiadó írásbeli engedélye nélkül reprodukálni, adatrendszerben tárolni, sokszorozni, bármely formában vagy eszközzel közölni illetve terjeszteni.

Felelős szerkesztő: Dr. Blutman László

Tipográfia és műszaki szerkesztés: Kovács Ildikó

A Szegedi Tudományegyetem Állam- és Jogtudományi Kar kiadása

Felelős kiadó: a kar dékánja

Készült az Innovariant Kft.-ben

Felelös vezető: Drágán György

ISBN 978-963-306-799-4 


\section{TARTALOM}

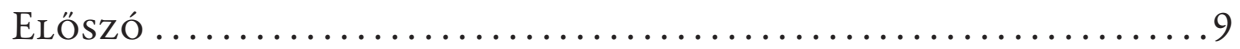

1. Bevezetés ........................................

2. A VÁRMegye egYetLen tiSZTVISELŐJe - A SZOLgabírói TISZTSÉG MEGJELENÉSE ÉS KIFEJLŐDÉSE ................... 17

2.1. A szolgabíró elnevezés eredete ....................... 17

2.2. Szolgabírák a nemesi vármegye első két évszázadában............ 18

2.3. Bírótársból a vármegyei feladatok betöltője................. 22

2.4. A járások mint a szolgabíráktól független adószedési körzetek...... 25

2.5. Az esküdtek megjelenése a vármegye életében ............... 26

2.6. A szolgabírói tisztség kialakulásának középkori gyökerei .......... 27

3. A JÁRÁS MINDENESE - A SZOLGABÍRÓi TISZTSÉG TÖRTÉNETE AZ ÁPRILISI TÖRVÉNYEK MEgSZÜLETÉSÉIG .................29

3.1. A Mohács utáni korszak közigazgatása..................... 29

3.2. A szolgabíró mint a vármegyei tisztviselők egyike ............. 29

3.3. A szolgabírói hatáskörök átalakulása .................... 32

3.4. A szolgabírák segítői a járási feladatok ellátásában............... 35

3.5. A járások és a szolgabírák összekapcsolódása ................. 36

3.6. A rendi kori szolgabírák jellegzetességei és a vármegyei közigazgatás modernizálása................................... 37

4. A neoabszolutizmus SZolgabírói hivatala ................39

4.1. A közigazgatási szervezet átalakulása a szabadságharc leverését

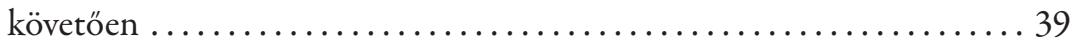

4.2. A birodalmi, egységes közigazgatási szervezet kiépítése.......... 40

4.3. A definitívum szolgabírói hivatala .................... 42

4.4. A közigazgatási szervezet visszarendeződése $\ldots \ldots \ldots \ldots \ldots \ldots \ldots . \ldots 5$

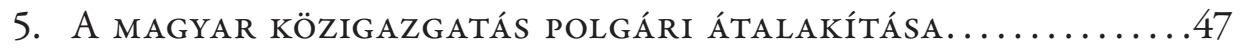

5.1. A köztörvényhatóságokról szóló 1870:XLII. tc. és az elfogadásához vezető okok ................................. 47

5.2. Centralizáció-decentralizáció a dualizmus rendszerében ........... 51

5.3. A közigazgatás modernizálásának követelményei a 19. században .... 53

5.4. A közigazgatás és az igazságszolgáltatás elválasztása............. 54

5.5. A közigazgatási szervezet törvényhatóságok általi kiépítése ......... 55

5.6. Az 1870:XLII. tc. végrehajtása ........................ 58

5.7. A törvényhatósági tervezetek kidolgozása a küldöttségek által......60 
6. A JÁRÁSOK TERÜlETI BEOSZTÁSA A TÖRVÉNyHATÓSÁGOK SZERVEZÉSI MUNKÁLATAIBAN ........................63

6.1. A ,járás” elnevezés partikuláris fogalomhasználatának egységesítése . 63

6.2. Egyszintü járási beosztás ...........................6 65

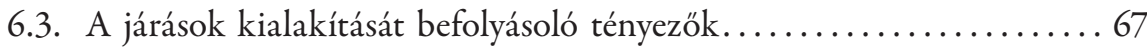

6.4. A járási szervezet a korábbi területi beosztás és a lakosságszám tükrében ........................................... 75

6.5. A járások elnevezése .................................. 77

6.6. A járási székhelyek...................................... 79

6.7. A törvényhatósági jogú és a rendezett tanácsú városok kapcsolata az alsó középszintű területi beosztással.................... 84

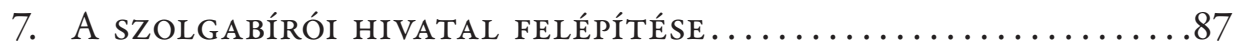

7.1. Az átalakításra váró járási szervezet..................... 87

7.2. A járás élén álló szolgabíró .......................... 88

7.3. Alszolgabíró vagy segédszolgabíró?...................... 92

7.4. Az esküdti pozíció kiiktatása a polgári közigazgatás szervezetéből .. 97

7.5. A szolgabírói írnok szerepe........................... 99

7.6. A közbiztonsági feladatokat ellátó járási személyzet............. 100

7.7. A polgári kor szolgabírói hivatala........................ 101

8. A SZOLGABÍRÁK JOGÁlLÁSA A KIEGYEZÉST KÖVETŐEN.........105

8.1. A szolgabírói tisztség elnyerésének szabályai .................. 105

8.2. A szolgabírák javadalmazása az 1870: XLII. tc. alapján ............ 108

8.3. A szolgabírák felelősségi kérdései ....................... 120

8.4. A törvényhatósági tisztviselők összeférhetetlensége az országgyűlési képviselöi megbízatással ........................... 124

8.5. A szolgabírói életpálya bemutatása ........................ 129

9. A sZolgabírÁK HATÁsKÖre ...............................

9.1. A szolgabírák katonasággal kapcsolatos teendői............... 132

9.2. A járási lakosság közmunka-kötelezettsége.................. 133

9.3. A községek és a szolgabírák kapcsolata...................... 134

9.4. A szolgabíró szerepe az adók beszedésében .................. 136

9.5. A közbiztonság fenntartása a járásokban .................. 137

9.6. A nem országos jelleggel előforduló szolgabírói hatáskörök........ 140

9.7. A szolgabírák szerepe a törvényhatóságok életében............. 142

10. A KÖZIGAZGATÁS ÉS AZ IGAZSÁGSZOLGÁLTATÁS ELVÁlASZTÁ-

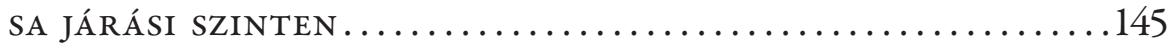

10.1. A hatalmi ágak elválasztásának megkérdőjelezése ............. 145

10.2. Vármegyei reakciók a hatalmi ágak elválasztása kapcsán ......... 146 
10.3. A törvénykezési feladatokat ellátó vármegyei segédszemélyzet „sorsa" ........................................ 148

10.4. A békebírói tisztség koncepciója ........................ 149

10.5. A két hatalmi ág elválasztásának lezárulta................... 150

11. A BELÜGYMINISZTÉRIUM BEFOLYÁSA A VÁRMEgYei AUTONÓ-

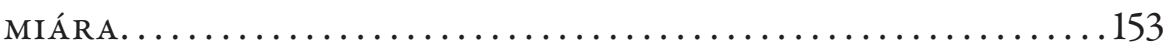

11.1. A tervezetek beérkezésének és minisztériumi megerősítésének időpontjai ...................................... 153

11.2. A belügyminisztérium megerősítési jogának tartalma .......... 155

11.3. A vármegyék közigazgatási költségeinek fedezési módja .......... 160

11.4. A tervezetek megerősítését végző belügyminisztériumi tanácsosok.. 164

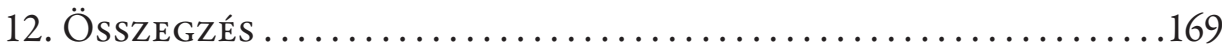

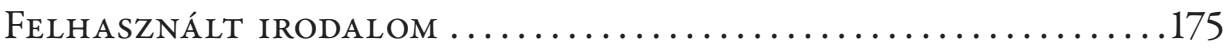

Melléklet: A vizsgált vármegyék JÁrási Beosztása .........213 



\section{ELőszó}

A Szegedi Tudományegyetem Állam- és Jogtudományi Doktori Iskolájának országosan is figyelemre méltó vállalkozása, hogy közzéteszi a kiemelkedő színvonalon megvédett PhD-értekezéseket. Pétervári Máté most megjelenő disszertációja is ezek közé tartozik.

Az értekezés tárgykörében levéltári forrásokra épülő szakirodalmi mű eddig nem született. A tárgyválasztás ezen túl is körültekintő volt, hiszen a közigazgatási járás hazánk történetének önálló jelentőségü és feldolgozható nagyságrendü intézménye, amely egy $\mathrm{PhD}$-disszertáció keretében az eredeti alkotás esélyét, egyben a monografikus összegzés lehetőségét kínálta.

Az értekezés nem csupán a közigazgatástörténet jelentős, de eddig kevés figyelmet kapott intézményét vizsgálta, hanem új közelítéseket kínált egy jogági részterület, a közigazgatási jog történetének elemzéséhez is. A közigazgatás hazai történeti folyamatait, más társadalmi szférákhoz való viszonyát, társadalmi beágyazódását ma már a köztörténet, a szociológia és az államtudomány képviselői is tudományáguk vizsgálati tárgyaként tekintik. A hazai közigazgatási jog történetének művelése azonban hosszú ideig háttérbe szorult, hiszen ennek tudományos közelítéséhez jogászi-jogtörténeti szaktudás és erre épülő módszertani ismeretek szükségesek. A közigazgatási jogi normarendszer elemzése, hatásvizsgálata, nemzetközi horizontú analízise nem végezhető el csupán az egykori szabályok nyelvtani értelmezése alapján. Pétervári Máté $\mathrm{PhD}$-értekezése ezen a téren tudománytörténeti jelentőségű, hiszen a járások polgári kori kialakítására, hatáskörükre, működésük rendjére és közigazgatási rendszerben elfoglalt közjogi helyzetükre irányadó jogi normák dogmatikáját és érvényesülésük folyamatát elsőként tárta fel.

A könyv igazolja a szerző alapos módszertani jártasságát is. A bevezető fejezetben rögzíti és a mű egészében érvényesíti a kutatás és feldolgozás tudományos módszertanának részleteit. A történeti (kronologikus) feldolgozás mellett nagy hangsúlyt fektet a dogmatikai elemzésre, a vonatkozó jogi normák valós tartalmának értelmezésére és a törvényhozói szándék feltárására. A szerző az archivált források feldolgozásának olyan metódusát választotta, amely alkalmas a törvényi rendelkezések gyakorlati érvényesülésének nyomon követésére. A feldolgozás során tudatosan és eredményesen alkalmazta a rendszertani értelmezést is.

A doktori mü - álláspontom szerint - legértékesebb része a levéltári források alapos feltárása és értő feldolgozása, amely lehetővé tette a reformáló központi szándék és a vármegyék korabeli álláspontjának részletes bemutatását. A disszertáció a Magyar Nemzeti Levéltár Országos Levéltárában elfekvő iratanyag, a belügyminisztériumhoz felterjesztett 30 törvényhatóság küldöttségi projektuma segítségével mutatja be a járások átalakítására irányuló helyi elképzeléseket. Ezek ismerete nélkül rejtve maradna előttünk a dualizmus-kori törvényi szabályozás háttere és a vonatkozó normák valós tartalma is.

A tudományos munka minden esetben az adott vizsgálati tárgy szakirodalmának hiánytalan feltárásával, a korábbi tudományos eredmények megismerésével kezdődik. 
Az értekezés szerzője mintaszerűen tisztázta a status quaestionis-t, alaposan feldolgozta a tárgykörével kapcsolatos egykori és a ma is alkotó szerzők müveit. A feldolgozások között alapművek, szakmai folyóiratok tanulmányai és publicisztikai munkák találhatóak. Az utóbbi idők tapasztalata alapján pozitív hangsúllyal kell említeni, hogy Pétervári Máté mellözte a tankönyvi irodalmat és a tudományos tartalmat nélkülöző feldolgozásokat. Az értekezés tárgyköréből folyamatosan publikált, így lehetővé vált számára a témakörrel foglalkozók szakmai reflexióinak megismerése és hasznosítása.

A szerző doktori felkészülését igényes szakmai műhely támogatta. Személyesen is tapasztaltam, hogy a disszertáns követte a tudományos vezetője, a tanszékvezetője és tapasztaltabb munkatársai tanácsait. Nem vitatható azonban, hogy a nyomtatásban megjelent mű szuverén alkotás, egy elhivatott, eredeti gondolkodású, kiváló tudományos érzékkel és felkészültséggel rendelkező fiatal tudós valódi értelemben vett monográfiája.

A Szegedi Tudományegyetem Állam- és Jogtudományi Doktori Iskolája az értekezés megjelentetésével egy magas színvonalú tudományos mü közzétételét tette lehetővé. A könyvvé formált disszertáció hasznos olvasmánya lesz a közjogi múltunk iránt érdeklődőknek, a közigazgatási jog művelőinek és a jogászképzésben részt vevő igényes hallgatóknak.

Budapest, 2021. március 9.

Stipta István 


\section{BeveZETÉS}

Az alsó középszintű közigazgatás intézménytörténete végigkíséri a magyar alkotmánytörténeti fejlődést, mivel a nemesi vármegye létrejöttével már a 13. században feltűntek a szolgabírák. A tisztség a társadalmi igényekhez igazodva egészen a 20. század közepéig fennmaradt. Az illetékességi területüket a 15. századtól meghatározó járások pedig 1984. január 1-jéig alkották a magyar közigazgatás megyék alatti szintjét. 1972-ben a politikai döntéshozatal előbb a járási tanácsok megszüntetésével, az önkormányzatiságot vonta el ettől a területi szinttől, majd 1983-ban az államigazgatási hatáskörök elvételével a járások közigazgatási szerepét is megszüntette, így Magyarország alsó középszintű területi beosztás nélkül maradt.

Az Alaptörvény rendelkezéseinek megfelelően a történeti hagyományokra támaszkodó jogalkotó azonban 2013. január 1-jével ismételten a magyar közigazgatási rendszer részévé tette a járásokat, amelyről a 2012. évi XCIII. törvény és a 218/2012. (VIII. 13.) kormányrendelet intézkedett. A kormányzat ezáltal az államigazgatási feladatok jelentős részét az önkormányzatoktól a járásokhoz telepítette, amely különleges aktualitását adja a járások történeti kutatásának. ${ }^{1}$ A monográfia célja így egy jelenkori jogtörténeti téma feldolgozása, amely alatt olyan hatályos jogi jogintézmény történeti gyökereinek feltárását érti Stipta István, amelynek több évszázadra visszanyúló elözményei vannak. ${ }^{2}$

Az alsó középszintủ közigazgatási egység nem tartozik a történészek vagy az alkotmánytörténettel foglalkozó kutatók népszerű témái közé. Az államszervezeti szinttel részben vagy egészben foglalkozó tanulmányok és könyvfejezetek mellett mindössze négy járásokkal foglalkozó szakirodalmi mủ jelent meg Magyarországon. Az első már igen korán napvilágot látott, 1842-ben Zsoldos Ignác kétkötetes munkával jelentkezett, amelyben a szolgabírói hivatallal kapcsolatos kérdéseket tárgyalta. ${ }^{3}$ Zsoldos az első olyan gyakorlati közigazgatási joggal foglalkozó jogtudós volt, aki a Magyar Tudományos Akadémia tagjai közé emelkedett. Monográfiája - rövid történeti bevezetőt követően - a szolgabírák hatáskörével foglalkozott. Az első kötet a korabeli igazságszolgáltatási feladatokat vázolta, míg a második a közigazgatási feladatköröket részletezte. Zsoldos a szolgabíróként eltöltött évei alatt szerzett tapasztalatait összegezte a kötetekben, így elsősorban kézikönyvként alkalmazható munkával segítette a korabeli közigazgatási tisztviselőket.

Kassay Adolf 1865-ben szintén a szolgabírák és az esküdtek munkájához támpontot nyújtó könyvet jelentetett meg, ${ }^{4}$ amely a Zsoldosnál található történeti bevezetőt is elhagyva kizárólag a hatásköri kérdéseket tárgyalta. A szolgabírákkal tudományos igénnyel foglalkozó monográfia 2008-ban jelent meg Béli Gábor tollából, aki e tisztség 13. századi

\footnotetext{
BARTA 2012, 28.

STIPTA 2016, 39.

ZsOLdos 1842a; Zsoldos 1842b.

KASSAY 1865.
} 
feltủnését és müködését vizsgálta. ${ }^{5}$ Takács Imre pedig 1963-ban kiadott munkájában a szocialista államszervezet önkormányzati szerveit, a járási tanácsokat mutatta be. ${ }^{6}$

A középkori vármegyék kapcsán igen élénk kutatásokat folytatnak a történészek, amelynek köszönhetően a szolgabírákkal és az esküdtekkel számos tanulmány foglalkozott. A járásokkal kapcsolatos kérdések részletes vizsgálata a többi korszakban és a dualizmus időszakában viszont hiányzik. Kizárólag a szolgabírákat középpontba állító munka Bató Szilvia írása, amelyben az 1848 előtti járást vezető tisztviselők igazságszolgáltatási hatáskörét elemezte. ${ }^{7}$ Pap József pedig a dualizmus kori szolgabírói tisztséggel szociológiai szempontból foglalkozott. ${ }^{8}$ A területrendezési koncepciókat Magyarország történetében vizsgáló Hencz Aurél a járások 1870:XLII. tc. alapján történő újjászervezését szintén nem elemezte. Monográfiájában ugyan utalt a járási szervezet átalakulására, de arról bővebben nem értekezett. ${ }^{9}$

A legátfogóbb járástörténeti összeállítást a Hétfa Elemző Központ készítette 2011ben a Nemzeti Közigazgatási Intézet megbízásából. A históriai áttekintést Dominkovits Péter és Horváth Gergely Krisztián készítette el. ${ }^{10} \mathrm{Ez}$ a munka a célhoz kötöttségének megfelelően a legfontosabb szekunder forrásokra támaszkodva készült el. A neoabszolutizmusra és a dualizmusra vonatkozó részei pedig a források hiányából is fakadóan alapvetően hézagosak. Emellett Marjanucz László készített áttekintő tanulmányt a járások történetéről a legfontosabb szekunder irodalomra támaszkodva, amelyben a szolgabírói hivatal polgári kori átalakítása kapcsán csupán a törvény rendelkezéseire hagyatkozott. ${ }^{11}$

Jelen munka első felében így indokoltnak tartom szekunder források felhasználásával a szolgabírói tisztség és a hozzá kapcsolódó hivatalnokok, jogintézmények kialakulását és változásait bemutatni az évszázadok sodrásában. A munka gerincét azonban a rendi kori járási szervezet polgári átszervezését megvalósító 1870:XLII. tc. vonatkozó rendelkezéseinek és végrehajtásának elemzése képezi. E jogszabály végezte el az alsó középszintű közigazgatás modernizálását így vizsgálata okszerü. A kapott információk jól kiegészítik a köztörvényhatósági törvény kapcsán született számos kutatási eredményt, amelyek az 1870:XLII. tc. megalkotását, ${ }^{12}$ a vármegyei törvényhatóságok ${ }^{13}$ és a törvényhatósági jogú városok müködését elemezték. ${ }^{14}$

A történeti áttekintés célja nem csupán a központi témának, a járási szervezet elemzésének előkészítése. A jogalkotó ugyanis a köztörvényhatósági törvényt deklaráltan a rendi hagyományokra építve alkotta meg, így a járások és a szolgabírák vizsgálatához

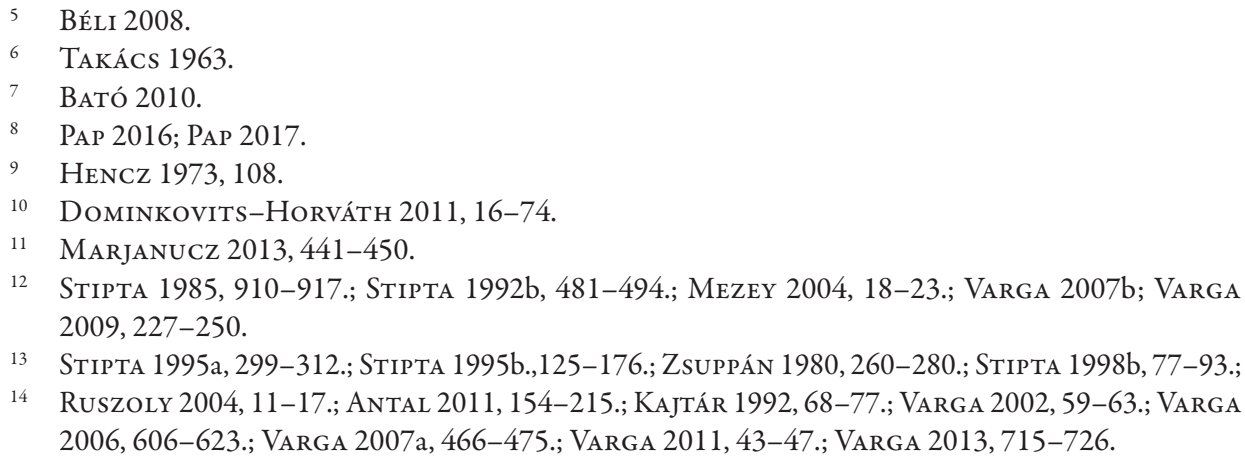


szükséges az egyes jellemzők (szolgabírák választása, a hivatal felépítése, járások elnevezése, stb.) történeti hátterére is rávilágítani. Jelen munka 2. és 3. fejezetében a szekunder történeti és alkotmánytörténeti szakirodalomból kívánok egységes képet kialakítani az 1848 előtti korszak alsó középszintű közigazgatásáról. A 2. és 3. fejezetet elkülönítem egymástól, mert a mohácsi csata a vármegye és a szolgabírói tisztség fejlődéstörténetében is fontos határvonalat képez. A 3. fejezetben már nem csak történeti munkákra tudtam alapozni a 19. század első felében megélénkülö jogtudománynak köszönhetően megjelent közjogról és közigazgatási jogról szóló szakirodalmi munkák miatt. A neoabszolutizmus korszakát tárgyaló 4. fejezetben az osztrák és a magyar szakirodalmi és történeti munkák mellett primer, levéltári forrásokat is elemzek. A neoabszolutizmus korszakában megtörtént a magyar közigazgatás modernizálása a birodalmi adminisztráció egységesítésének köszönhetően, az októberi diploma és az Ideiglenes Törvénykezési Szabályok azonban visszaállították a rendi kori közigazgatási és törvénykezési szervezetet. ${ }^{15}$

A járási szervezetet is a vármegyékhez hasonlóan a polgári kor követelményeinek megfelelően kellett átszervezni a kiegyezést követően, mivel az 1869:IV. tc.-ben megtörtént az igazságszolgáltatás és a közigazgatás elválasztása, valamint a kiegyezés közjogi konstrukciójának megfelelően alakították át a végrehajtási szervezetet. Erre vonatkozóan azonban csak két szakaszában $(61 . \S ; 91 . \S)$ található rendelkezés a köztörvényhatóságokról szóló 1870:XLII. tc.-nek. Ezek azonban a szolgabírói hivatalokról részletes szabályozást nem nyújtanak. A törvény e két szakasza kapcsán felmerül, hogy mi volt a háttere a szabályozásnak. A kérdés megválaszolásához elsőként a törvény indokolását és országgyülési vitáját vizsgáltam. Az indokolás nem érintette a járási szervezet szabályozását, ${ }^{16}$ míg a hosszú parlamenti vitában a képviselők nem foglalkoztak a járásokkal kapcsolatos kérdésekkel. A belügyminiszter, Rajner Pál a vita első napján csupán a szolgabírák választási módjára adott magyarázatot, ${ }^{17}$ ezt követően a járások kérdéséhez nem szóltak hozzá a képviselők. ${ }^{18}$ Ezt indokolhatta volna az, hogy a jogszabály csupán a fennálló állapotokat konzerválta. A rendi korszakból ismert járási szervezettel azonban nem vágtak tökéletesen egybe a köztörvényhatósági törvény szolgabírói hivatalai.

Ennek megfelelően primer források segítségével tárom fel a járási szervezet kiépítésének részleteit, ugyanis maradtak erre vonatkozóan vitás kérdések, ha ezt a jogalkotás során nem is tárgyalták. A fejezetek elején a kapcsolódó törvényi szabályozást mutatom be normatív-leíró módszerrel, amelynek ismeretében elemzem ezek végrehajtását, gyakorlati megvalósulását. Az egyes vármegyék megoldásait hasonlítom össze, amelyből egységes kép rajzolódik ki a törvényhatóságok álláspontjaiból. A belügyminisztériumi reflexiókból pedig az ezzel kapcsolatos kormányzati szándék válik felvázolhatóvá. A járási szervezet egyes kérdéseit tehát közigazgatási jogi, dogmatikai szempontból kívánom vizsgálni a levéltári forrásokra támaszkodva. Az egyes vármegyék tervezetei kapcsán a komparatisztika módszerét alkalmazom. Emellett a korabeli és a kurrens szakirodalmat is feldolgozom a

15 VON Stubenrauch 1856, 25-32.

16 KI 1869. V. k. 188-200. - 485. Indokolás a köztörvényhatóságok, és a községek rendezéséről szóló törvényjavaslatokhoz.

17 KN 1869. IX. k. 46.

18 KN 1869.X.k. 282. 
polgári kori szolgabírói hivatalra vonatkozóan, amelyet kiegészítek az országgyủlési naplókban és irományokban megjelenő kormányzati és ellenzéki álláspontokkal. A korabeli jogi szaksajtó a közigazgatási szervezeti változások kapcsán a járásokkal érdemben nem foglalkozott, így erre nem támaszkodhattam.

Ezzel módszerként mintegy „fordított” szubjektív teleologikus módszert alkalmazok, ugyanis a törvény szövege és annak végrehajtása alapján igyekszem felfejteni a jogalkotó célját, és nem a jogalkotási folyamat dokumentumai alapján értelmezem a jogszabályt. ${ }^{19}$ Erre azért van szükség, mivel a törvény indokolásában vagy országgyủlési vitájában nem találunk erre vonatkozó iránymutatást. A belügyminisztériumi munkálatok alapján ez azonban felderíthető, mivel a törvényjavaslatot a belügyminisztériumi tanácsosok dolgozták ki és az országgyủlési vita során nem módosítottak az alsó középszintű közigazgatásra vonatkozó szakaszokon.

A szabályozás „mozgatórugóinak” feltárása amiatt is indokolt, mert a korszak közigazgatási jogtudósai „nem produkáltak közigazgatási jogtudományi vizsgálatokat,” így a közigazgatási jogismereti irányzatba sorolhatók. ${ }^{20}$ Emiatt e tankönyvekben nem található iránymutatás arra nézve, hogy az 1870:XLII. tc. járásokra vonatkozó rendelkezései maguk után vontak-e valamilyen változást.

Jelen munkában a Magyar Nemzeti Levéltár Országos Levéltárában megtalálható iratanyagot vizsgálom. A belügyminisztériumnak felterjesztett küldöttségi projektumok közül 30 törvényhatóságét dolgozom fel. ${ }^{21}$ Véleményem szerint ez már olyan nagyságú minta, amely reprezentatívnak tekinthető. Különösen, mivel az ország eltérő részeinek vármegyéit vizsgálom, amelyek között kisebb és nagyobb lakosságszámmal rendelkező törvényhatóságok is találhatók, sőt erdélyi vármegyék, kiváltságos kerületek és székely székek is felfedezhetők. Az erdélyi vármegyék a kiegyezést követő visszacsatolásnak köszönhetően ugyanis szintén a kutatás tárgyát képezik az anyaország vármegyéihez hasonlóan. A horvát-magyar kiegyezés miatt kialakuló önálló belügyi igazgatás következtében a horvát területeken kiépített járási szervezettel nem foglalkozom, ahogyan a Határőrvidékkel sem. Az általam vizsgált tervezetek alapján így megfelelő elvi következtetéseket lehet levonni az 1870:XLII. tc. nyomán Magyarországon kialakított járási rendszerre nézve. Érdemes megjegyezni, hogy a járási beosztással kapcsolatos szervezési munkálatok színvonala igen egyenetlen volt, így a vizsgált kérdések egy része nem volt megválaszolható a vármegyei tervezetek alapján. Különösen igaz ez a megállapítás a hatásköri szabályzatok vonatkozásában, mivel a vármegyék egy része ennek elkészítését elmulasztotta, vagy csupán a belügyminisztériumi iratanyagból vesztek el e dokumentumok némely esetben.

19 ЈАКАв 2011, 89-90.

20 Szamel 1976, 390.

21 A vizsgált törvényhatóságok: Alsó-Fehér vármegye; Arad vármegye; Aranyosszék; Bars vármegye; Békés vármegye; Bereg vármegye; Csanád vármegye; Csongrád vármegye; Doboka vármegye; Fejér vármegye; Felső-Fehér vármegye; Fogaras vidék; Gömör és Kis-Hont vármegye; Hajdú kerület; Hont vármegye; Krassó vármegye; Komárom vármegye; Kővár vidék; Küküllő vármegye; Nagy-Kikinda kerület; Nógrád vármegye; Pozsony vármegye; Sáros vármegye; Szabolcs vármegye; Szepes vármegye; Temes vármegye; Trencsén vármegye; Veszprém vármegye; Zala vármegye; Zaránd vármegye. 
Jelen müben fontosnak tartom a járási szervezetet kizárólag az 1870:XLII. tc. tükrében vizsgálni, mivel több szakirodalmi munka azonosnak tekinti azt az 1886:XXI. tc. által létrejött struktúrával. ${ }^{22} \mathrm{~A}$ két törvényhatósági törvény a járások tekintetében azonban több elemében is eltérő volt. A munkának viszont nem célja az alsó középszintű közigazgatás kapcsán az európai kitekintés, mivel sem az országgyưlési vitában, sem a vármegyék tervezeteiben nem találtam utalást arra, hogy a magyar szabályozást valamely külföldi minta befolyásolta volna. A neoabszolutizmus korszaka viszont befolyást gyakorolt a magyar közigazgatási szervezetre, így annak bemutatása alkalmával utalok az osztrák államszervezet megoldásaira.

Az 5. fejezetben az 1870:XLII. tc. megalkotásához vezető okokat, valamint a korszak közigazgatásának legfontosabb alapelveit veszem számba. Ezt követően pedig a törvény vármegyék általi végrehajtását mutatom be. Ennek alapja, hogy a törvényhatóságok kötelesek voltak tervezeteiket a belügyminisztériumnak megerősítés végett megküldeni. A belügyminisztériumi tanácsosok a tervezetek jogszabállyal való összhangját alaposan ellenőrizték. Ha ennek eredményeképpen kifogást emeltek valamely tervezett rendelkezés ellen, akkor módosítás céljából visszaküldték azokat a vármegye közgyülésének.

A 6. és 7. fejezetek tehát a minisztérium és a törvényhatóságok együttes munkája alapján mutatják be a járások és a szolgabírói hivatalok kapcsán felmerült dilemmákat. A 8. fejezetben a szolgabírák jogállását a tervezetek és a minisztériumi reakciók mellett a törvényhatósági törvény 1870 . évi végrehajtásától függetlenül a belügyminisztériumhoz felterjesztett ügyekkel illusztrálom. A következő fejezetben pedig a járások szervezeti jellemzését egészítem ki a hatásköri szabályozásuk jellemzésével. A 10. fejezet az igazságszolgáltatási és közigazgatási hatalmi ág elválasztását mutatja be, amely kérdés szoros kapcsolatban van a járási szintre telepített hatáskörökkel. A 11. fejezet pedig a korábbiaktól némiképp eltér, mivel nem konkrétan a járásokkal foglalkozó törvényi szabályozást elemzi, viszont a járások kialakításához szorosan kapcsolódó kérdéseket (a tervezetek beérkezésének időpontja, a belügyminisztérium megerősítési jogának tartalma, a közigazgatási költségek fedezésének módja, a tervezetek kapcsán intézkedő belügyminiszteri tanácsosok) mutat be.

Az egyes kérdések bemutatása során arra keresem a választ, hogy valóban csupán a rendi hagyományokra építkezve szabályozták-e a járási szervezetet, így csupán a fennálló állapotokat konzerválták-e. Emellett vizsgálom, hogy mi volt a jogalkotás célja az alsó középszintű közigazgatásra vonatkozó rendelkezések kapcsán. Csupán a centralizáció erősítésére törekedett-e a jogalkotó, vagy más rendeltetése is volt az új szabályozásnak? Kérdésként merül fel, hogy az 1870:XLII. tc. hatályba lépését követően a központi kormányzat korlátozta-e már a vármegyék önkormányzati jogosultságait.

A levéltári források feldolgozása alkalmával a következő hivatkozási elvet követem. A több vármegyei forrásra való hivatkozás alkalmával a fondot, amelyben a dokumentumok találhatók, csak az első alkalommal jelölöm meg, majd utána felsorolom az oda tartozó ügyszámokat. A belügyminisztériumi munkálatok során a beérkezö tervezetekre

22 Csizmadia 1972, 434-435.; Máthé 1990, 75.; Föglein-Horváth-Mezey 2001, 354-355.; FöGLEIN et. al. 2003, 416.; TAKÁCS 1963, 28-30. 
vonatkozóan küldték meg a leiratokat a tanácsosok, amelyre ismételten reagálhattak a vármegyék. A vármegyei iratokat, ha erre lehetőség nyílt, a hozzá kötődő belügyminisztériumi ügyszámmal azonosítottam, mivel e dokumentumokon nem mindig található meg a határozat száma, és ezek feltüntetése kaotikus képet mutatott volna. A rendezetlen iratok esetén a dokumentum kelte alapján kapcsoltam a belügyminisztériumi ügyszámhoz az adott vármegyei tervezetet.

Az egyes törvényhatóságok neveit a kiadványok különbözőképpen tüntették fel, így az egységesség érdekében a vármegyék esetében a Szapáry-féle javaslat 101-102. oldalán fellelhető írásmódot alkalmazom, mivel ez az összes törvényhatóság nevét tartalmazta. ${ }^{23}$ Ezt az indokolja, hogy több törvényhatóságot a hamarosan bekövetkező reformok megszüntettek, így ezek neveinek modernebb helyesírása nem vált általánosan elfogadottá. Ezzel szemben a városi törvényhatóságok neveit a napjainkban használt alakban tüntetem fel, mert ezek elnevezése jelenleg is használatban van, így a régi helyesírás alkalmazása archaizáló megoldás lenne. A községek nevei már nem minden esetben azonosíthatóak a mai településnevekkel, így ezekben az esetekben a tervezetekben feltüntetettekhez igazodom.

Köszönetemet szeretném kifejezni a jelen munka megszületéséhez nyújtott segítségükért és ösztönzésükért tanszékvezetőmnek, Prof. Dr. Homoki-Nagy Máriának és témavezetőmnek, Dr. Varga Norbertnek. Emellett hálás vagyok a mű elkészítése során kapott szakmai iránymutatásért Prof. Dr. Deák Ágnesnek, Prof. Dr. Stipta Istvánnak, Dr. Antal Tamásnak, Dr. Béli Gábornak és Dr. Legeza Dénesnek. A Bécsben végzett kutatásaimhoz pedig elengedhetetlen volt Dr. Christian Neschwara támogatása, amelyért őt külön köszönet illeti. A doktori értekezés könyvvé formálásához emellett rendkívüli módon hozzájárultak Prof. Dr. Mezey Barna és Prof. Dr. Szabó István opponensi munkájuk során megfogalmazott észrevételei, amelyért ezúton szintén hálámat fejezem ki. 


\section{A VÁRMEgYe EGYETLEN TISZTViselője - A SZOLGABÍRÓI TISZTSÉG MEGJELENÉSE ÉS KIFEJLŐDÉSE}

\subsection{A szolgabíró elnevezés eredete}

A szolgabírák eredetét kutatva érdemes elöször az elnevezés etimológiai hátterét megvizsgálni. A szolgabíró latin megfelelője a iudex nobilium, vagy annak összevont változata a judlium, amely a kora újkorban terjedt el..$^{24}$ Béli Gábor megállapítása alapján a tisztség magyar nevének eredetét már 1722-ben Bencsik Mihály arra vezette vissza, hogy a judlium a szerviensek, a királyi szolgák bírája volt. ${ }^{25} \mathrm{~A}$ témával foglalkozó kutatók szintén e feltevésből eredeztették a kifejezést. ${ }^{26} \mathrm{~A}$ királyi szolgák megnevezés társadalmi rangként való megjelenését Béli Gábor a 13. század elejére teszi, amely időszakban a csak a királynak szolgálattal tartozó, módosabb közszabadokat illették ezzel a névvel. ${ }^{27} \mathrm{~A}$ kifejezést minden bizonnyal a köznyelv még a 14. században is használta, így a szolgabíró megjelölés 13 . századi eredetét nem igazolja az, hogy a királyi szolgák megjelenése ezzel az időszakkal azonosítható. ${ }^{28} \mathrm{~A}$ szolgabíró név latin tükörfordítása egy 1332-ben kelt idézésben tűnt fel elsőként. ${ }^{29}$ A szóalak magyar változatának első nyomát Iványi Béla pedig egy 1404ben kelt oklevélben találta meg. ${ }^{30}$

A szolgabíró elnevezés eredetét a királyi szolgákra visszavezető egyértelmü álláspontot Zsoldos Attila kérdőjelezte meg arra hivatkozva, hogy az a már említett, egyetlen oklevélben megjelenő latin elnevezésre építve alakult ki. ${ }^{31} \mathrm{~A}$ források segítségével arra a következtetésre jutott, hogy mivel a nemesek magukat nem a király szolgáinak titulálták, így nem valószínű, hogy ez alapján nevezték volna meg bírájukat. A korábbi elnevezéssel kapcsolatos ellenérvként vetette fel: mivel a nádori vagy a megyei bírósági közgyülés nem csupán a nemesek ügyeiben járt el, így a szolgabíró nem csak a királyi szerviensek bírája volt. Ezen okokból Zsoldos egy 17. századi nyelvészeti példát visszavetítve azt állapította meg, hogy az elnevezés a bíráskodásban betöltött szerepre utalhat, mert a szolgabírák a fóispán mellé beosztott társbírákként, önálló joghatóság nélkül segédkeztek az ítélkezés során. ${ }^{32}$

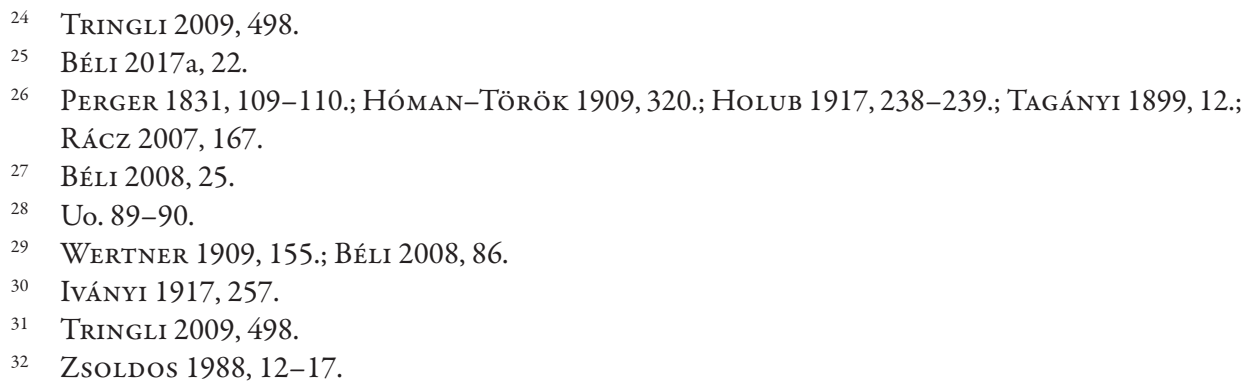


A korszakkal foglalkozó számos újabb munka elfogadja Zsoldos álláspontját. ${ }^{33} \mathrm{~A}$ feltevést azonban gyengíti, hogy Béli Gábor azóta az említett 18. század elején kelt forrással igazolta az elnevezés eredetét, amely esetben Bencsik Mihály minden bizonnyal nem a Zsoldos által megkérdőjelezett egyetlen oklevélből indult ki. ${ }^{34}$

A tisztség latin megfelelője a iudex nobilium terminus abból az időszakból származik, amikor a királyi szerviensek már nemesként nevezték meg magukat. A királyi szerviensi és a nemesi megnevezés azonosulásának deklarálása IV. Béla 1267. évi dekrétumának tulajdonítható. ${ }^{35}$ Ennek megfelelően Béli Gábor a 13. század hetvenes éveinek végére teszi a latin terminus technicus állandósulását. ${ }^{36}$

\subsection{Szolgabírák a nemesi vármegye első két évszázadában}

Szent István az államépítés keretében hozta létre a királyi vármegyéket, amelyek területalapú, központokba helyezett hadszervezetként funkcionáltak. ${ }^{37} \mathrm{~A}$ vármegyék élén az uralkodó nevében és parancsa alapján eljáró megyésispán állt, aki a központi vár irányítását is ellátta, amelyhez tartozó vártisztek munkáját igénybe vehette feladatai ellátása során. Az ispán segítői között azonban nem található a királyi vármegye időszakában olyan közreműködő, aki a szolgabírói tisztség jellegzetességeit magán viselné. ${ }^{38}$ Mivel a várszervezet tisztjei látták el az ispán által rájuk bízott feladatokat, így elkülönült hivatali tisztikar sem jött még létre. ${ }^{39}$

A vármegyeszervezet nemesivé alakulásának legfontosabb mérföldköve a szolgabírák 13. század utolsó harmadára tehető feltűnése volt az igazságszolgáltatás vidéki szerveiben. ${ }^{40} \mathrm{Az}$ újabb kutatások ugyanis cáfolták azt az álláspontot, hogy a kehidai oklevélben eljáró bírák ennek a tisztségnek az előzményeiként lennének azonosíthatóak, ugyanis az ügyben eljáró bírák nem valamiféle szervezeti tagolódásnak köszönhetően nyerték el a tisztségüket, hanem ún. fogott bírákként jelentek meg. ${ }^{41}$

Az álláspontok eltérőek abban a kérdésben is, hogy mikor jelentek meg a vármegye életében ezek az új tisztviselők. Béli Gábor hasonlóan Szűcs Jenőhöz az 1267. évi dekrétum 5. cikke alapján a király által a jogtalanul elfoglalt földekkel kapcsolatos eljárásra kiküldött bíróságok tagjaiként azonosította a szolgabírákat az 1268-ban kelt ítéletlevelekben. Szűcs azonban a iudex nobilium gyökereit 1260 tájára teszi, míg Béli szerint az 1268-as oklevél az első alkalom, amikor a szolgabírák feltűnnek a vármegyék müködésé-

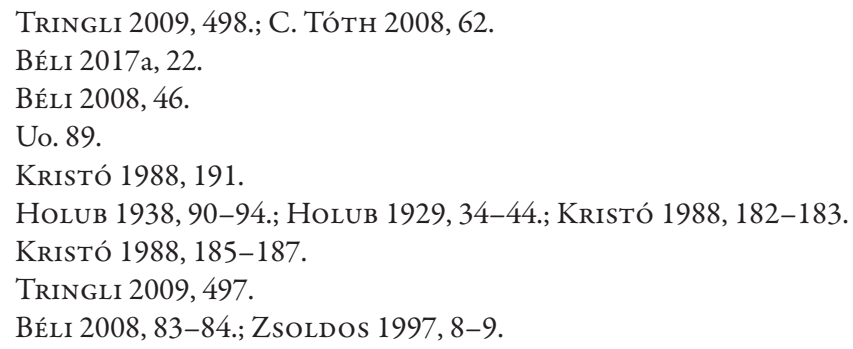


ben. ${ }^{42}$ Zsoldos ezzel szemben arra az álláspontra helyezkedik, hogy a földek visszavételére kiküldött személyek nem tekinthetők a szolgabírák előképének, hanem Csák Máté 1273. évben a szlavóniai gyülésen kelt rendelkezéseiben a föispán mellé rendelt négy nemesi bíró azonosítható a jogintézmény történeti gyökereként. ${ }^{43}$ Béli ehhez hasonlóan úgy véli, hogy a szolgabírák részvétele a vármegyei ítélkezésben az 1270-es években rögzült. ${ }^{44} \mathrm{~A}$ szolgabírák első feltűnése az egyes vármegyékben eltérő időpontokra tehető, de egységesen a 13. század végére és a 14 . század első felére adatolható. ${ }^{45}$

A szakirodalom egységesen elutasítja, hogy a szolgabírák elödjeinek tekinthető négy nemesi bíró a nemesi önszerveződés eredményeképpen létrejövő választott tisztségviselő lett volna a 13. században. A szolgabírák vármegyei ítélkezésben való szerepvállalása ugyanis felülről jövő kezdeményezésként a királyi udvar hatására gyökeresedett meg a hazai joggyakorlatban. Arra egyértelmü adatok mutatnak, hogy az első iudex nobiliumokat a 13. század második felében a király nevezte ki és királyi parancs alapján kiküldött bírákként jártak el. ${ }^{46}$ Zsoldos véleménye szerint a nemesi bírák a sedria müködésébe való bevonásának országos elterjedéséhez Erzsébet özvegy királyné 1273-as régensi müködése járult hozzá, amelyre IV. (Kun) László kiskorúsága miatt volt szükség. ${ }^{47}$

Béli Gábor szerint a iudex nobilium a 14. század harmadik évtizedétől vált egyértelműen választott tisztségviselővé, ezáltal a vármegyei autonómia egyik első megjelenése a szolgabírák nemesek általi választása volt. ${ }^{48} \mathrm{Az} 1435$. évi dekrétum már a nemesek által választott tisztségként jelölte meg a szolgabírák státuszát. A iudex nobilium volt az első olyan tisztség, amely pozícióját a nemesség szavazatainak eredményeképpen nyerte el, mivel a korszakban a föispán még maga nevezte ki alispánját. ${ }^{49}$

Egyértelműnek tünhet, hogy a vármegye teljes nemesi közössége választhatta meg a szolgabírákat. Ennek azonban ellentmond egy 1464-ben Pozsony vármegyében kelt oklevél, amely szerint a szolgabírák csak az adott járás nemességének akaratából nyerhették el tisztségüket. ${ }^{50}$ Egyetlen forrásból azonban nem vonható le az a következtetés, hogy ez minden vármegyében így történhetett, sőt C. Tóth Norbert már a 16. századból származó Szabolcs vármegyei jegyzőkönyvvel arra hozott példát, hogy a teljes vármegye nemessége választotta a szolgabírákat. ${ }^{51}$ Okleveles források hiányában nem állapítható meg, hogy melyik szerv keretei között választhatta a vármegye nemessége a szolgabírákat. A téma legtöbb kutatója úgy véli, hogy ez a középkori vármegyékben a sedria jogosultsága volt, mivel ez volt az egyetlen olyan fórum, amelyen meghatározott időközönként köteles volt megjelenni a vármegye nemessége. ${ }^{52}$ Ezt a megállapítást kétségessé teszi azonban,

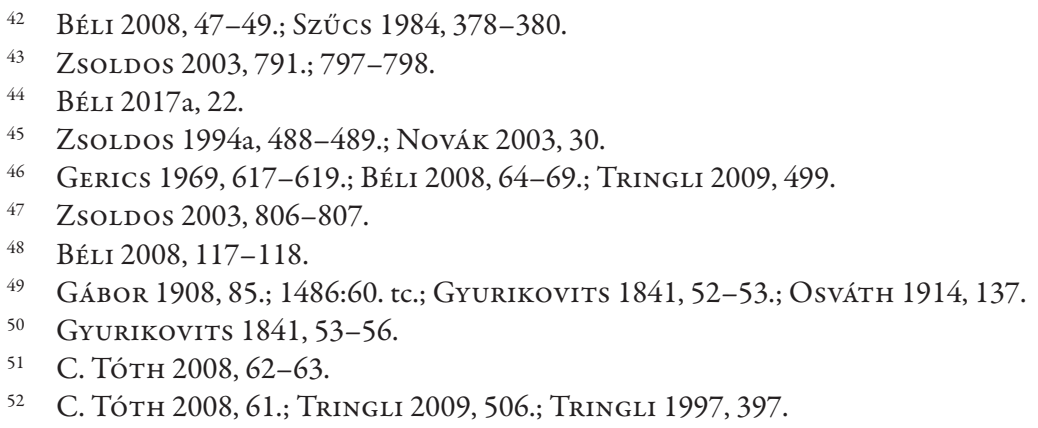


hogy Béli Gábor szerint a bírói szerveken kívül a közügyek tárgyalására is hívhatott össze a vármegye hatósága gyűlést, így nem feltétlenül a sedria volt a választás megtartására egyedül alkalmas vármegyei fórum..$^{53}$

A tisztséggel járó feladatokat a hivatal megjelenésétől jellemzően négy szolgabíró látta el az egyes vármegyékben. Ezt igazolja az 1290. évi dekrétum 3. és 8. fejezete is. ${ }^{54}$ Az erdélyi vármegyék mellett azonban Árva, Bács, Bodrog, Kraszna, Krassó, Moson, Pilis, Pozsega, Szerém, Külső-Szolnok, Torna, Trencsén, Verőce és Zólyom vármegyében is csupán két szolgabíró alkotta a főispánnal a vármegye hatóságát. ${ }^{55} \mathrm{C}$. Tóth Norbert szerint a két iudex nobiliummal rendelkező vármegyék amiatt térhettek el az általános gyakorlattól, mert a vármegye területén csekélyebb számú nemes élt.. ${ }^{56}$

A szolgabírák a 13. század második felétől a 14. század közepéig az előkelőbb, nagyobb vagyonnal rendelkező nemesek közül kerültek ki, akiknek azonban a bárók közé emelkedésére kevés esély mutatkozott. ${ }^{57} \mathrm{~A} 15$. századi példák viszont már arra mutatnak, hogy a nemesség közepesen vagy kevéssé tehetős rétegéhez tartozó családjaiból kerültek ki a vármegye e tisztviselői. ${ }^{58} \mathrm{Az}$ azonban az egész országra kiterjedően nem jelenthető ki, hogy csupán az egytelkes nemesek jövedelemforrásává vált volna a szolgabírói tisztség viselése. ${ }^{59} \mathrm{~A}$ hivatalviselők szegényebb társadalmi rétegből való kikerülését Engel Pál a vármegye ítélkezési hatáskörének csorbításával magyarázta, ugyanis a megye joghatósága alól a bírósági exemptiók segítségével bizonyos privilegizált személyek birtokait kivonták, valamint egyre gyakoribbá vált a földesurak számára a „pallosjog” adományozása. ${ }^{60} \mathrm{~A}$ tisztségnek tehát fö jellegzetessége volt, hogy csupán nemesek tölthették be. ${ }^{61}$

A tisztség betöltésére vállalkozók társadalmi rangjának visszaesését mutatják a 15 . századi törvényeink is. Az 1415/1417. évi „Javaslatok” 18. cikkelye a szolgabírói hivatal tekintélyét ugyan még nem a jelöltek megfelelő vagyoni hátterének biztosításával kívánta megörizni, ${ }^{62}$ hanem úgy rendelkezett, hogy a derék és lelkiismeretes férfiak közül kerüljenek ki a szolgabírák. ${ }^{63}$ Luxemburgi Zsigmond a vármegyék megerősítésére hozott törvényei között az 1435. évi második dekrétum azonban már azt mondta ki, hogy a szolgabírák a tehetösebb és jómódú nemesek közül választandók. ${ }^{64} \mathrm{Ez}$ célszerűnek

53 BÉLI 2017a, 23-24.

54 Béli 2008, 53.; Gábor 1908, 85-86., DRMH I. 44-45.; Holub 1929, 153.; C. Tóth 2008, 54.; Gyurikovits 1841, 55-56.; BaKÁcs 1971, 22.; C. Tóth 2008, 58-59.; Havassy 1986, 45.; IuszTin 2013, 254.

55 Gábor 1908, 180.; W. Kovács 2010, 36.; Csukovits 1997, 379.; C. Tóth 2007, 397.; RüszFogarasi 2009, 3.; C. Tóth 2010a, 321-323.

56 C. Tóth 2010a, 324.

57 BÉli 2008, 179.; Zsoldos 2003, 803-804.; ENGEL 1998, 108.

58 KÁDAs 2014a, 108.; KÁDAS 2015a, 28-30.

59 C. Tóth 2008, 67.; Kádas 2014b, 127.; Engel 1998, 108.

60 ENGEL 2001, 154-155.

61 GÁBOr 1908, 85.

62 Ez a jogi dokumentum nem dekrétum volt, csupán egy Zsigmond király által készíttetett dekrétum-tervezet, amely néhány fontos reformgondolatot tartalmazott. - DRH I. 397-398.

63 C. Tóth 2008, 61.

64 ENGEL 2001, 186-188. 
mutatkozott amiatt, mert ebben az időszakban még nem kaptak fizetést a vármegyétől a tisztviselők, valamint azért is, mert a megfelelö anyagi háttér tekintélyt biztosított a feladat ellátóinak a vármegye lakosai körében.

A tehetősek háttérbe szorulását vagy inkább háttérbe vonulását a hivatalviselés terén az is igazolja, hogy I. Mátyás 1486. évi dekrétumában megismétli, hogy a szolgabírákat a vármegyében lakó birtokos nemesség köréből a jómódúak és érdemesek közül válasszák a nemesek. A 15-16. századi Tolna megyei példák arra utalnak, hogy azok a törekvések, amelyek a szolgabírói tisztségbe igyekeztek a jómódú és tekintélyes személyeket juttatni, sikertelenek maradtak. Inkább a kisnemesi réteg jövedelemkiegészítő tevékenységeként funkcionált e vármegyei tisztség betöltése ${ }^{65} \mathrm{Ez}$ a megállapítás azonban nem érvényesült az egész országban, mivel Heves vármegyében főként éppen a jómódú nemesek jutottak a tisztségbe. ${ }^{66}$

A nemesi cím megléte mellett a tisztségre való megválasztás másik feltétele az volt, hogy a jelölt az adott vármegye birtokosai közül kerüljön ki. A szabály érvényesülését igazolják Magyarország és Erdély eddig vizsgált vármegyéi. ${ }^{67}$

A iudex nobilium mandátumának időtartama a 13-15. századi oklevelek alapján egyértelműen nem mutatható ki. ${ }^{68}$ Holub és Béli is egy évre tette a megbízatásuk hosszát azzal a kikötéssel, hogy minden bizonnyal az alkalmas egyének újraválaszthatók voltak. ${ }^{69} \mathrm{Az}$ 1435. évi második dekrétum 2. cikkelye ezt a nézetet egyértelműen nem erősíti meg, mivel csupán azt határozta meg, hogy a szolgabírák kötelesek egy évig viselni a tisztséget. C. Tóth úgy véli, hogy új iudex nobilium választására nem minden évben, hanem csak lemondásuk, felmentésük vagy haláluk esetén került sor. Ezzel indokolja azt, hogy a 15. században több vármegyében is hosszabb ideig töltötték be a szolgabírák tisztségüket. ${ }^{70}$ Kádas István újabb kutatásai is megerősítik a több évig tartó hivatalvállalást. ${ }^{71} \mathrm{~A}$ Béli Gábor által a 14. századból citált adatok is egybevágnak e feltevéssel, ugyanis arra mutatnak, hogy legalább egy évig tartott egy-egy megválasztott mandátuma, de többen is hosszabb ideig töltötték be a tisztséget. ${ }^{72}$

A hivataluk betöltésekor a nemesi bírák esküt tettek..$^{73} \mathrm{Az}$ eskütételi kötelezettséget és annak szövegét az 1435. évi második dekrétum foglalta törvénybe, amelyet Mátyás nagyobb dekrétumának 73. cikkelye erősített meg azzal a kikötéssel, hogy az esküt a vármegyében szükséges letenniük a szolgabíráknak.

Az 1435. évi második dekrétum 2. cikkelye már arról is rendelkezett, hogy a megválasztott egyének kötelesek voltak elvállalni a szolgabírói tisztséget, ellenkező esetben

SZAKÁLY 1997, 421.

Havassy 1986, 45.

67 C. Tóth 2008, 65.; W. Kovács 2010, 33-35.; SZAKÁLy 1997, 418.; KádAs 2015a, 27-28.; KÁdAS 2020, 34 .

68 BÉLI 2008, 118.

69 Béli 2008, 118.; Holub 1929, 152.

70 C. Tóth 2008, 64-65.; SzakÁly 1997, 417.; Rüsz-Fogarasi 2009, 4-5.

71 KÁdAs 2020, 22-28.

72 BÉLI 2008, 118-120.

73 BéLi 2008, 47-48.; C. Tóth 2008, 67.; GÁBOR 1908, 85. 
25 márka büntetés terhelte a vármegyei nemesség akaratát visszautasító személyt. Ez a rendelkezés arra utal, hogy a nemesek között már kevésbé volt népszerű a hivatal viselése, amely magyarázható az ezzel járó feladatok szaporodásával, fóként a népszerütlen adóbehajtás terén. A mandátumuk lejártával azonban öt évig nem terhelte őket a hivatalviselési kötelezettség. Ezt a rendelkezést I. Mátyás is megerősítette 1486. évi nagyobb dekrétumában, ami azt mutatja, hogy a Zsigmond uralkodása alatt felmerült problémákat nem sikerült orvosolni a század végére sem.

\subsection{Bírótársból a vármegyei feladatok betöltője}

A tisztség elnevezése is azt jelzi, hogy kezdetben a szolgabírák feladatainak jelentős hányadát az igazságszolgáltatási teendők tették ki. A nemesek bírái az 1290. évi dekrétum 8. cikkelyének rendelkezései alapján a nádort a nádori közgyűlésen, a 3. cikkely szerint a főispánt pedig a vármegye bírói fórumán törvénykezési feladataiban segítő bírótársak voltak, akiknek kötelező volt részt venniük az ítélkezési tevékenységben. ${ }^{74} \mathrm{Az} 1268$ után kelt oklevelek szintén a vármegyei törvényszéken történő társasbíráskodásban való szerepvállalásra utalnak. ${ }^{75} \mathrm{Az} 1290$. évi dekrétum így nem új bírói fórumokat hozott létre, hanem a már müködő szervek eljárását szabályozta.

A nádori közgyűlés feladata a nyilvános gonosztevők felkutatása és megbüntetése volt, de emellett a királyi birtokokkal és a rendi állással kapcsolatos vitás kérdésekben is eljárt. ${ }^{76} \mathrm{~A}$ bírói közgyűlések tartása a 13. századot követően nem kizárólagosan a nádorhoz kötődött. Ezen keretek között a király parancsára az ország más nagybírája, más báró vagy éppen a föispán is intézhette egy vagy több vármegye peres ügyeit, amelyen az érintett vármegyék nemesei számára kötelező volt a megjelenés. ${ }^{77}$ A nyilvános gonosztettek elkövetőivel szembeni eljárás az úgynevezett levelesítés volt, amely során a megye alispánjai, szolgabírái és a közgyűlésre választott esküdtek egy listát állítottak össze a vármegye ismert gonosztevőiről. Az így elkészített jegyzéket adták át a közgyưlés vezetőjének, aki az összeállítók segítségével meghozta a végső ítéletet. ${ }^{78}$

A megyei törvényszék, a sedria hatásköre szintén kiterjedt a nyilvános gonosztevőkkel szembeni eljárásra, emellett ítéletet hozhatott hatalmaskodási ügyekben és az ingatlan tulajdonjogát érintő perek kivételével magánjogi vitás kérdésekben. ${ }^{79}$

A 14. században a közgyűlések voltak a vidéki bíráskodás meghatározó fórumai. ${ }^{80}$ Jelentőségük azonban olyan módon lecsökkent a 15. században, hogy I. Mátyás 1486-

\footnotetext{
74 Béli 2008, 47.; 80.; Stipta 1998a, 37.; Holub 1929, 167.; 193.; BÉLi 2017b, 121.

75 BÉLI 2008, 90.

76 Stipta 1998a, 36.; Holub 1929, 178.; Tringli 1997, 398.

77 TRINGLi $1997,387$.

78 TRINGLi 1998, 3.; 10-11.

79 BÉLi 2008, 140; C. Tóth 2008, 105-107.; 1454:15. tc.

80 GÁBOr 1908, 95.
} 
ban nagyobb dekrétumában megszüntette a nádori közgyűlés működését. ${ }^{81} \mathrm{~A}$ nádor vidéki igazságszolgáltatási tevékenységének visszaszorulásával párhuzamosan erősödhetett meg a vármegyei törvényszékek és a föispán által összehívott megyei törvénykezési gyűlések müködése. ${ }^{82} \mathrm{~A}$ szolgabírák mindkét szerv müködésében társbírákként vállaltak szerepet. ${ }^{83}$

A középkorban tehát a szolgabírák nem rendelkeztek önálló bírói fórummal. ${ }^{84} \mathrm{Az}$ 1290. évi dekrétum azonban hatékonyan korlátozta a nádor és a föispán törvénykezési hatáskörét azáltal, hogy nem bíráskodhattak a szolgabírák részvétele nélkül. ${ }^{85} \mathrm{~A}$ négy szolgabíró a föispánnal és a helyettes ispánnal képviselte a megyei hatóságot, ${ }^{86}$ így a iudex nobiliumok a vármegye legbefolyásosabb tisztségviselői közé tartoztak. ${ }^{87} \mathrm{~A}$ szolgabírák és a föispán együttes eljárási kötelezettsége alól kivételt képezett Pest és Pilis vármegye, mivel főispán hiányában Pest vármegyében 1342-től, Pilis vármegyében pedig a 15. századtól a szolgabírák látták el a vármegyei feladatokat. ${ }^{88} \mathrm{E}$ kivételes megyei szokásokat erősítette meg az 1495:20. tc. akképpen, hogy a szolgabírák a jobb módú nemesekkel kiegészülve ítélkezzenek. A források azonban nem igazolják, hogy az esküdtek valóban részt vettek volna az igazságszolgáltatásban. ${ }^{89}$

A 14. század második feléből már találhatóak arra is adatok, hogy a vármegye képviselőjeként általában a szolgabírák vettek részt az úriszéki jogszolgáltatás munkájában a földesúr bíráskodási tevékenységének ellenőrzése céljából. A iudex nobilium az e bírói fórumon történtekről a megyének jelentést tett a legközelebbi sedrián..$^{90}$

A szolgabírák hatásköre a 13. század végére és a 14. század elejére már nemcsak az igazságszolgáltatásban bírótársként való közreműködésben merült ki, hanem hiteleshelyi tevékenységet is folytattak mind a vármegyei törvényszék keretében, mind a négy bíró önállóan eljárva. E tevékenység során a feladataik közé tartozott a határjárás, a tudományvételek foganatosítása és a birtokfoglalások hitelesítése. ${ }^{91} \mathrm{~A}$ teendőik közé tartozott még a kamarahasznának és Luxemburgi Zsigmond korától az új adónemnek, a hadiadónak a kirovásában és a beszedésében való részvétel.${ }^{92} \mathrm{~A}$ kamarahasznával kapcsolatos eljárást Róbert Károly 1342 . évi dekrétumának 3.\$-a és 21 .\$-a részletezte, amely szerint a pénzváltás öt személy, köztük egy szolgabíró jelenlétében történt. Már Nagy Lajos korától

\footnotetext{
81 STIPTA 1998a, 36.

82 Stipta 1998a, 37-38.; BÉli 1987, 69.

83 GÁBOR 1908, 150-152.

84 EMBER 1946, 41.

85 Holub 1929, 154.; BÉLI 2008, 104.

86 Mezey 2018, 135.; Bónis 1996, 18.

87 GÁBOR 1908, 86.; 98.; TRINGLI 2009, 510-511.; BÉLI 2017a, 21.

88 TRINGLI 2001, 155.; 169-170.

89 TRINGLi 2010, 394-395.

90 GÁBor 1908, 35-36.; Holub 1929, 155.; 229.; TRingli 2009, 502.; Liktor 2017, 222-223.; HajNik 1899, 98.; С. То́тн 2010b, 406.

91 BéLi 2008, 104.; 147-149.; 178.; GÁBor 1908, 87.; 96.; Holub 1929, 154.

92 BÉLI 2005, 104-105.; BÉLI 2008, 146-147.; GÁBOR 1908, 115-117.; HOLUB 1929, 154.; 279-289.; Lengyel 1965, 223-224.; Tringli 2009, 504-505.; Neumann 2009, 183.
} 
az adószedő és a szolgabírák feleltek a kamarahaszna beszedéséért, ${ }^{93}$ amelyet az 1435 . évi második dekrétum 7. cikkelye is megerősített. Az adó meg nem fizetése esetén a büntetés beszedését szintén a föispán és a szolgabírák feladataként deklarálta. Az adók behajtásának feladata más esetben is a szolgabírákat terhelte. ${ }^{94}$

A szolgabírák vármegyei hatóságként más bírák vagyoni büntetéseit és egyéb bírságokat is végrehajtottak. ${ }^{95}$ Emellett igazgatási jellegü tevékenységek is megjelentek a hatáskörükben a 15. század elejére, amelynek bizonyítéka az 1435. évi második dekrétum 7. cikkelye és az 1458:15. tc., amelyek alapján a szolgabírák a föispánnal járnak el a földesúr és a szabad költözködési joguk gyakorlásában erőszakkal gátolt jobbágyok ügyeiben. ${ }^{96}$ Luxemburgi Zsigmond a szolgabírák feladatai közé utalta még az 1435. évi első dekrétum 6. cikkelye szerint a katonaállítási kötelezettség meghatározásához szükséges lajstromok összeállítását, amelyek az egyes bárókhoz és nemesekhez tartozó jobbágyok számát tartalmazta. Ezzel a telekkatonaság intézményét megvalósító törvények végrehajtását bízta az uralkodó a vármegye e tisztviselőire. ${ }^{97}$

A szolgabírák javadalmazását biztosította, hogy az ítélkezési tevékenység során kiszabott bírságok $2 / 3$ része a szolgabírákat és a föispánt illette, a már említett vagyoni büntetések végrehajtása esetében pedig a behajtott pénzösszeg 1/3-án osztoztak a szolgabírák a főispánnal. ${ }^{98} \mathrm{Az} 1435$. évi második dekrétum 3. cikkelye meghatározza azt is, hogy a föispán és a szolgabírák egyenlő részben osztoznak a vármegyei törvényszéken kiszabott büntetéseken. A szolgabírák emellett az adószedéssel kapcsolatos feladataikért is kaptak némi díjazást. ${ }^{99}$

A megyei hatóság által elkövetett visszaélések esetében a király és a király nevében az országbíró rendelkezett hatáskörrel, hogy felelösségre vonhassa a vármegye képviseletében eljáró tisztviselóket. Gábor Gyula kutatásai nyomán váltak ismertté olyan oklevelek, amelyek szerint a hatósági felelősség egyetemlegessége okán a szolgabírákkal szemben is indultak eljárások. ${ }^{100}$

Annak ellenére, hogy a föispán vagy az alispán és a négy szolgabíró a vármegye nevében jártak el az általuk kiállított okleveleket nem a vármegye pecsétjével látták el, hanem a saját családi pecsétjeikkel hitelesítették. E megoldáson az 1435. évi második dekrétum 2. cikkelye sem változtatott, csupán a pecsét könnyủ felismerhetőségét követelte meg. Ennek oka, hogy a megyei pecsétek a 14. és 15 . században még ismeretlenek voltak. II. Ulászló 1498-ban jogosította fel elöször Somogy vármegye nemességét az általuk készített okiratok közhitelüségének vármegyei pecséttel történő igazolására, amelyet követően más vármegyékben is megjelentek a hivatali pecsétek. ${ }^{101}$ Ezt a gyakorlatot terjesztette

C. Tóth 2008, 138-139.; Tringli 2001, 179.

MÁlyusz 1957, 69.; 118.; 121.; KÁdAs 2020, 48-53.

BÉli 2005, 90-91.; BÉli 2008, 143-146.; GÁBOR 1908, 172-177.

Liktor 2016, 343.; C. Tóth 2008, 63.

Mályusz 1984, 108.; ENGel 2005, 146.

BÉli 2008, 145.; GÁbor 1908, 86.; Holub 1929, 155.

KÁdAs 2020, 54.

GÁbOR 1908, 98-102.; C. Tóth 2008, 111.

KÁDAs 2017, 653. 
ki minden bizonnyal a király az 1550:62. tc.-ben, ${ }^{102}$ amely szerint a vármegyék önálló pecséthasználati jogot nyertek. ${ }^{103}$

A szolgabírák jellemzőn nem önállóan jártak el, hanem több szolgabíró együttesen hitelesítette a cselekményt, ${ }^{104}$ vagy a megyei emberek kísérték el a szolgabírákat, akik tanúsították az elvégzett feladatokat. ${ }^{105}$

\subsection{A járások mint a szolgabíráktól független adószedési körzetek}

A szolgabírák között a középkorban még nem alakult ki a terület szerinti munkamegosztás, így járásokra osztott eljárási területről az esetükben nem beszélhetünk. Gábor Gyula korabeli oklevelek segítségével cáfolta azokat az állításokat, amelyek szerint a szolgabírói tisztség létrejötte az Árpád-korban egyúttal a járások kialakítását is indukálta. Zsigmond király 1399-ben kiadott rendeletével bizonyította, hogy ebben az időszakban még biztosan nem beszélhetünk járásokról, mivel a szolgabírákra rótt hadkötelesek összeírásánál nincs utalás arra, hogy a vármegyét bármilyen eljárási területre osztották volna. Véleménye szerint a járások kialakulása a szolgabírákkal az élükön a 15. század első évtizedére tehető, amely következtetését arra alapozta, hogy az 1427-ből fennmaradt adóösszeírási lajstromot az egyes szolgabírák már csupán a vármegye meghatározott területére nézve készítették el. ${ }^{106}$

Engel Pál és C. Tóth Norbert is az 1427. évi lajstromok segítségével igazolta a járások létét, amelyek a megyében állandósult központokhoz kötődő adószedési körzetekként jöttek létre. C. Tóth azonban kétségbe vonta, hogy ez a területi egység első megjelenése lenne, mert Ung vármegye esetében arra a megállapításra jutott, hogy a 14. század végi jobbágyokat összeíró lajstrom már a járások nyomait mutatja. ${ }^{107}$ Mivel a járások eredete az adóigazgatáshoz köthető, emiatt vetette fel azt is, hogy a járások létrejötte az I. Károly által 1336-ban bevezetett kamarahaszna beszedésével hozható összefüggésbe. ${ }^{108}$ A 14 . századi eredet irányába mutatnak az újabb kutatások is. ${ }^{109}$

Holub József a járások gyökereit arra vezette vissza, hogy Zala vármegyében több megyei törvényszék is müködött és ezek személyi illetékességének meghatározása eredményezte a vármegye területének felosztását. Következtetésének alapjául az szolgált, hogy egy 15. századi oklevél a districtus, a járás latin megfelelőjét használja a megyei törvényszékek kerületeként. A szolgabírákat pedig az egyes törvényszékekhez osztották

BORSA $1984,60-62$.

GÁBOR 1908, 110-111.; Holub 1929, 317-319.; C. Tóth 2008, 109-110.; LengYel 1965, 218. FöGLEIN 1924, 481.

104 BÉLI 2008, 171.; TÖRÖK 1907, 31.

105 Neumann 2005, 268.; Kádas 2016, 128.; Kádas 2015b, 121-122.

106 GÁBOR 1908, 42-44.

107 C. Tóth 2007, 399.; 402; 409-410.; C. Tóth 2008, 26.; Engel 1989, 12.

108 С. Тóth 2010a, 320.

109 KÁdas 2020, 36.
} 
be, amely alapjául szolgált az egyes tisztviselők megjelölésének. ${ }^{110} \mathrm{C}$. Tóth Norbert szerint viszont a vármegyei ítélöszék illetékességi területe és a járások között nem mutatható ki közvetlen kapcsolat. A jelenkori kutatások arra utalnak, hogy a középkorban a szolgabírák eljárása nem volt szoros kapcsolatban a járásokkal, eljárási területük nem igazodott a járási felosztáshoz. ${ }^{111}$ A kutatási eredményekből arra a megállapításra juthatunk, hogy a nemesi vármegye működését nem befolyásolta a járási beosztás, az csupán a pénzügyigazgatás adminisztrációjának területi kereteit biztosította. ${ }^{112}$

A járási beosztás szerkezete kapcsán érdemes megemlíteni C. Tóth Norbert azon következtetését, hogy több vármegye esetében a járások területét a vármegye központjából kiindulva alakították ki, ugyanis a járások kapcsolódtak a vármegye székhelyéhez. ${ }^{113} \mathrm{~A}$ járásokat a középkori néhány adat szerint leggyakrabban csupán sorszámmal jelölték az adó-összeírásokban, de már ekkor megjelent a tájnévvel való azonosításuk. ${ }^{114} \mathrm{~A}$ járások területét befolyásoló tényező a domborzat és a vízrajz mellett a nemesség létszáma volt. ${ }^{115}$

\subsection{Az esküdtek megjelenése a vármegye életében}

Az esküdtek már a 14. század elején megjelentek bírótársakként a törvénykezési eljárás során, ám még nem az egyes szolgabírákhoz rendelt bizonyságtevőként, hanem csak az egyes közgyülésekre választva, így nem is nevezhetők tisztviselőknek. ${ }^{116} \mathrm{Az}$ 1444:10. tc. rendelte el, hogy a vármegyékben a törvénykezési és oklevélkiadási feladatokban való segédkezés céljából a nemesek közössége négy becsületes személyt válasszon, akik a fóispán és a négy szolgabíró társaiként járjanak el a vármegyékben. ${ }^{117} \mathrm{~A}$ megválasztott személyek ezáltal az egyes közgyűlésekre választott esküdtek és a megyei emberek szerepét vették át, ugyanis a vármegyei hatóság vizsgálatok lefolytatására is kiküldte őket. ${ }^{118} \mathrm{Az}$ okleveles források tanúsága szerint a tisztség ismeretlen okból kérészéletűnek bizonyult, mivel 1445 után már nem találhatók adatok a tisztség betöltőiről. ${ }^{119}$ A középkor jogi gondolkodásában nem számított ez kivételes jelenségnek, ugyanis az érvényesülő jogot elsősorban az oklevelekből kiolvasható szokásjog határozta meg és nem volt ritka, hogy a törvények a mindennapokra nézve hatástalanok maradtak. ${ }^{120}$

I. Mátyás nagyobb dekrétuma ismételten úgy rendelkezett, hogy olyan tisztviselők választandók a vármegyékben a tehetősebb és helyben lakó nemesek közül, akik a hite-

110 Holub 1929, 214-215.

111 C. Tóth 2008, 25-26.; Lengyel 1965, 223-224.; Tringli 2009, 505.

112 C. Tóth 2010b, 412-413. Kádas 2020, 34.

113 C. Tóth 2005, 180.; Neumann 2009, 186.

114 C. Tóth-Tringli-Draskóczy 2005, 519.

115 C. То́тн 2010b, 413.

116 BÉli 2008, 161.; GÁBor 1908, 90.; Tringli 2009, 507.

117 DRMH II. 101.; BÉLI 2017a, 27.

118 KÁDAS 2015c, 47.

119 Holub 1929, 159-160.; C. Tóth 2010b, 410.; KÁdas 2015c, 46-47.; NovÁK 2003, 30.

120 ECKHART 1931, 285-286. 
leshelyek küldöttjeivel ellátják a törvénykezéssel kapcsolatos feladatokat. ${ }^{121} \mathrm{~A}$ vármegyék egy évre választottak igényük szerint nyolc és tizenkét fö közötti létszámú esküdtet, akik bírság terhe mellett kötelesek voltak elfogadni a tisztséget. ${ }^{122}$ Emellett eskütételi kötelezettség is terhelte őket. ${ }^{123} \mathrm{Ez}$ az újonnan megjelent választott vármegyei tisztség a megyei hatóság részévé vált és az alkalomszerűen választott királyi ember feladatait vette át. ${ }^{124} \mathrm{~A}$ királyi emberek ugyanis a 13 . századtól vizsgálatokat, birtokba iktatásokat, idézéseket és megintéseket végeztek, ${ }^{125}$ akiket az egyes eljárások elvégzésére esetileg az ügy kezdeményezője választhatott ki az oklevél kiadója által megjelölt személyek közül. ${ }^{126}$ Az uralkodó az egyes eljárási cselekményekre megbízott királyi emberek helyébe így egy állandó tisztségviselőt állított.

Mátyás nagyobb dekrétuma egyértelműen az 1444:10. tc.-ben megjelenő esküdti tisztségnél bővebb hatásköröket szabott számukra. ${ }^{127} \mathrm{~A}$ megyei feladatok elvégzése során jellemzően a szolgabíróval együttesen jártak el, így a törvényszéki eljáráshoz szükséges vizsgálatokat végezték, valamint az állami és egyházi adó beszedése során az adószedők munkáját a szolgabírák és az esküdtek közösen segítették. ${ }^{128}$

Annak ellenére, hogy a törvény szövege az ítélkezésben való részvételt nem nevesítette az esküdtek esetében, az oklevelek szerint megjelentek bírótársakként a sedrián. ${ }^{129}$ Ezt alátámasztja az is, hogy az 1492:53. tc. kifejezetten megtiltotta, hogy a vármegyei törvénykezésben a föispán és a szolgabírák mellett esküdtek is szerepet vállaljanak. II. Ulászló dekrétumában a túlzott anyagi terhekre hivatkozva az esküdti tisztség megszüntetése mellett döntöttek, így az igazságszolgáltatáshoz járuló teendők elvégzését ismételten csupán a királyi és káptalani emberekre bízták. Neumann Tibor véleménye szerint azonban ezek a magas költségek inkább az esküdtekre, sem mint az országlakosokra hárulhattak. ${ }^{130} \mathrm{Az}$ 1492:53. tc. rendelkezései ellenére a vármegyei gyakorlat azt mutatja, hogy az esküdtek közremüködése továbbra is kimutatható a törvénykezésben és a vármegyei feladatok ellátásában. ${ }^{131}$

\subsection{A szolgabírói tisztség kialakulásának középkori gyökerei}

Összegzésképpen leszögezhető, hogy az Árpád-kor utolsó évtizedeiben kialakult szolgabírói tisztséget a középkor jogi gondolkodásának megfelelően a hagyományos szo-

21 1486:8. tc.

122 BÉLI 2014, 249.

123 Neumann 2005, 264.

124 LiKTOR 2016, 337.

125 ENGel 2003, 578.; 585.

126 ZsOLDOS 1994b, 354.

127 KÁdAs 2015c, 54.

128 Neumann 2005, 269-270.

129 Holub 1929, 160-161.; Neumann 2005, 267-268.

130 Neumann 2005, 286-287.

131 Holub 1929, 161-162.; Neumann 2005, 287-288.; Novák 2003, 30.; C. Tóth 2010b, 410-411. 
kásjog őrizte meg. ${ }^{132} \mathrm{Az} 1435$. évi dekrétum és I. Mátyás nagyobb dekrétuma csupán a tisztség kapcsán felmerülő problémákat kívánta orvosolni azzal, hogy az arra alkalmas személyeket juttatta hivatalba. A iudex nobilium egyéves mandátummal rendelkező a nemesek által, a nemesek közül választott megyei tisztviselő volt, akinek javadalmazását a főispánnal való eljárásukból befolyó büntetések és bírságok fedezték. A főispán mellett a szolgabírák a vármegye egyetlen tisztségviselöjeként, annak legfontosabb alakjai voltak. ${ }^{133}$ Hatáskörüket az Árpád-korban az ítélkezési tevékenység határozta meg, de a vegyesházi királyok időszakában az uralkodók közhatalmi tevékenységének bővülésével a nemesi bírák feladatai is szaporodtak. Mohács előtt még hiányzik a judlium és az esküdt közötti szoros együttmüködés a hivatali tevékenység során és a vármegyék meghatározott területére, a járásokra korlátozódó eljárási terület sem hangsúlyos. A tisztség középkori gyökerei, amelyek egybeesnek a nemesi rend létrejöttével a reformkorig nagy tekintélyt biztosítottak a szolgabírák számára. 


\section{A JÁrÁs MINDENESE - A SZOLGabírói TISZTSÉG TÖRTÉNETE AZ ÁPRILISI TÖRVÉNYEK MEGSZÜLETÉSÉIG}

\subsection{A Mohács utáni korszak közigazgatása}

Az I. Mátyás uralkodása alatt létrejött nagyobb dekrétum jelentős mértékben hozzájárult a rendek megerősödéséhez. ${ }^{134}$ Ennek köszönhetően a vármegyei nemesség képes volt maga kialakítani az új közigazgatási és bíráskodási eljárásokat, amikor az ország három részre szakadása miatt Magyarország erős központi hatalom nélkül maradt. ${ }^{135}$ Ezen átalakítás következtében fejlődhetett ki az a vármegyei közgyűlés, amely már elsősorban a közigazgatási feladatok ellátását végezte és szervezte. ${ }^{136} \mathrm{~A} 16$. század elejére alakult ki a megyei szervezet önkormányzati jellege a közgyűlésnek a megerősödésével. ${ }^{137} \mathrm{E}$ változás gyökeresen átalakította a vármegye működését, emiatt érdemes új korszakként vizsgálni a tisztviselők működését a Mohács utáni Magyarország vármegyéiben. ${ }^{138}$

A rendi korban a vármegyéket ügyeik vitelének, a lakosság igazgatásának és a törvények végrehajtásának vonatkozásban széleskörű döntési jogosultságok illették meg, így egységes szerkezetủ vármegyei apparátus nem jöhetett létre. Ennek köszönhetően összefüggő kép a közigazgatás 16-17. századi vidéki szerveiről csak az egyes vármegyék közigazgatását feldolgozó munkákból kapható, a megyei szintű levéltári források országos feldolgozásával azonban napjainkig adós maradt a magyar jogtörténetírás. ${ }^{139} \mathrm{~A}$ 19. században a megélénkülő jogirodalomnak köszönhetően már több információval rendelkezünk a vármegyei közigazgatás működéséről.

\subsection{A szolgabíró mint a vármegyei tisztviselők egyike}

A társadalmi fejlődés következtében a 16. századtól fokozatosan bővült a vármegyei tisztikar, így a szolgabíráknak megszűnt a Mohács előtti időszakban meglévő kiemelt helyzete. Egyenrangúvá váltak a többi választott tisztviselővel, akiket az önkormányzati jogosultságokkal megerősített vármegyei közgyủlés választott. ${ }^{140} \mathrm{~A}$ szolgabírák

134 Liktor 2016, 344-345.

135 DEGRÉ 2004a, 163.

136 BÉLI 1987, 70.

137 Degré 2004a, 163.

138 TRINGLi 1997, 397.

139 ECKhart 1931, 277.

140 BÉLI 1988, 39. 
megválasztásának szabályait a vármegyei közgyűlésen megjelenő nemesek határozták meg. A tisztújító közgyülést a legtöbb megye évente tartotta, azonban voltak olyan törvényhatóságok, amelyek csupán három-négyévente hirdették meg azt. ${ }^{141}$ Ennek megfelelően a szolgabírák hivatalviselésének időtartama is igen eltérő volt az egyes vármegyékben, általában egy évre szólt, de ezt nem lehetett általános szabályként értelmezni. ${ }^{142}$ A hivatal betöltői újraválaszthatók voltak, így a munkájukat jól végző szolgabírák az esetek többségében hivatalukban maradhattak. ${ }^{143} \mathrm{~A}$ gyakorlati példák azt mutatják, hogy nem volt ritka a hosszú, akár évtizedes hivatalviselés sem. ${ }^{144} \mathrm{Az}$ 1723:56. tc. tette csupán három évente kötelezővé a tisztújítást. E törvény megszületésétől a szolgabírák mandátuma megválasztásuktól három évig terjedt, amelyet a 19. századi kodifikációs munkálatok során hat évre kívántak növelni. Ezt azzal indokolták, hogy a hosszabb ideig betöltött hivatal biztosítani tudja a megfelelő szakértelmet a tisztséget betöltő számára. A Zala megyei véleményezők azonban ezt az érvelést nem támogatták, mivel véleményük szerint az alkalmas tisztviselőt leggyakrabban újraválasztják a közgyülésen, viszont az alkalmatlan egyéneket semmiképpen sem szabad hat évig tisztségükben meghagyni. ${ }^{145}$

Az alispánt és a főszolgabírákat a török hódoltság korától a 18. század elejéig a vármegyei közgyűlés résztvevői közfelkiáltással a főispán által jelölt három vagy négy személy közül választhatták. ${ }^{146}$ A 18 . század második felében már előfordult, hogy a föszolgabírák némely esetben fejenkénti szavazás útján nyerték el a tisztségüket. Degré Alajos kutatásai alapján a Helytartótanács azonban 1819-ben már határozottan elrendelte, hogy a tisztújítás alkalmával közfelkiáltás útján ne történhessen választás, ehelyett kötelezte a vármegyéket a fejenkénti szavazásra. Mivel nem minden vármegye követte a rendelkezést, a Helytartótanács 1821-ben ismételten megerősítette ezt az eljárási szabályt. 1827-ben végül enyhítettek a rendelkezésen, és abban az esetben, ha a nemesség egyértelmű akarata kitűnt, akkor engedélyezték a közfelkiáltás útján történő választást. Ennek köszönhetően a legtöbb esetben közfelkiáltással történt a tisztújítás, és csak ritkán került sor fejenkénti szavazásra. ${ }^{147}$ Erdélyben ezzel szemben a megyei tisztviselőket a főispán nevezte ki és vonta felelősségre, a közgyülés csupán hozzájárult ehhez. ${ }^{148}$

A szolgabírákat a vármegye nemessége a vármegye birtokos nemesei közül választotta, amely szokást az 1723:56. tc. erősített meg. A jelöltek bírság terhe mellett megválasztásuk esetén kötelesek voltak elvállalni a tisztséget, ${ }^{149}$ amely 15 . századi törvényi rendelkezést az 1559:54. tc. megismételt. A megválasztottak az ünnepélyes beiktatásuk alkalmával a megyei közgyủlés elött esküt tettek. A szolgabírák a középkor végén ki-

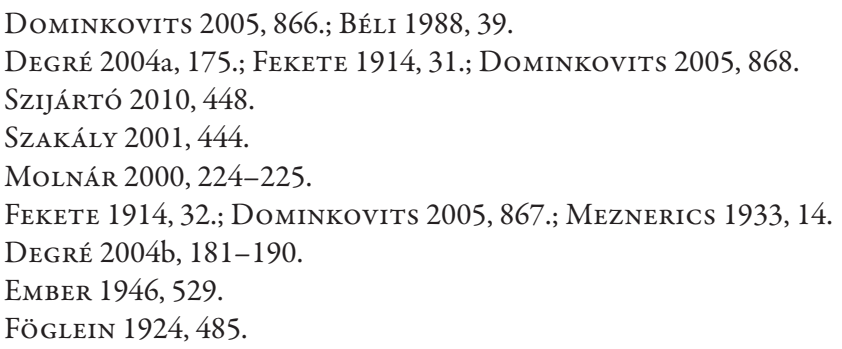


alakult gyakorlatnak megfelelően jellemzően a kis- és középbirtokos nemesek közül kerültek ki. ${ }^{150}$

A teljes apparátus fizetését és napidíját a vármegyei közgyülés határozta meg. ${ }^{151} \mathrm{Ha}$ misnak bizonyult az a nézet, hogy a vármegye tisztikara ingyenesen látta el feladatait, és csupán a bírságokból részesült és napidíjat kapott, ${ }^{152}$ ugyanis vármegyénként és tisztségenként eltérő nagyságú fizetést nyújtott számukra a vármegye a 16 . századtól. ${ }^{153} \mathrm{~A}$ csekélyebb mértékủ fizetést azonban a napidíjakból, a bírságokból és a perköltségből befolyó pénzösszeg valóban jelentősen kiegészítette. ${ }^{154} \mathrm{~A}$ vármegyei tisztségek nobile officiumként való megjelölése Meznerics szerint nem az ingyenes hivatalviselési kötelezettséget jelentette a nemesek számára, hanem azt, hogy a hivatal elnyerését csupán bírság terhe mellett utasíthatták vissza. ${ }^{155}$

Az ország nagybíráinak megmaradt a jogosultsága a vármegyei tisztviselők felelősségre vonására, amellyel azonban ritkán éltek, így a hivatalnokok ellenőrzését és a velük szembeni eljárások lefolytatását a közgyülés végezte. ${ }^{156} \mathrm{~A} 19$. században így már magától értetődőnek vette a közigazgatási kérdéseket tárgyaló közjogi-politikai kodifikációs bizottság, hogy a vármegyei közgyülés jogosult a tisztviselők felelösségre vonására. ${ }^{157}$ Ahogyan említettük, a 16. századra már megjelentek a vármegyei pecsétek, de még a 17. században is fennmaradt az a gyakorlat, hogy a vármegyei tisztviselők saját pecsétjeiket használták hivatalos eljárásuk során. ${ }^{158}$

A vizsgált korszakra esik a török hódoltság időszaka, amikor az ország egyes területein a korábbi közigazgatási berendezkedést részben felváltotta a török adminisztráció, ${ }^{159}$ azonban ezeken a területeken sem szakadt meg a vármegye és a szolgabírák működése. ${ }^{160} \mathrm{~A}$ tisztviselők nem ritkán a szomszédos vármegyéből intézték a török megszállás alatt álló vármegyék ügyeit. ${ }^{161}$ A 17. század első felére az a gyakorlat alakult ki, hogy a vármegyék hódoltsági tisztviselőkkel bővítették a vármegyei

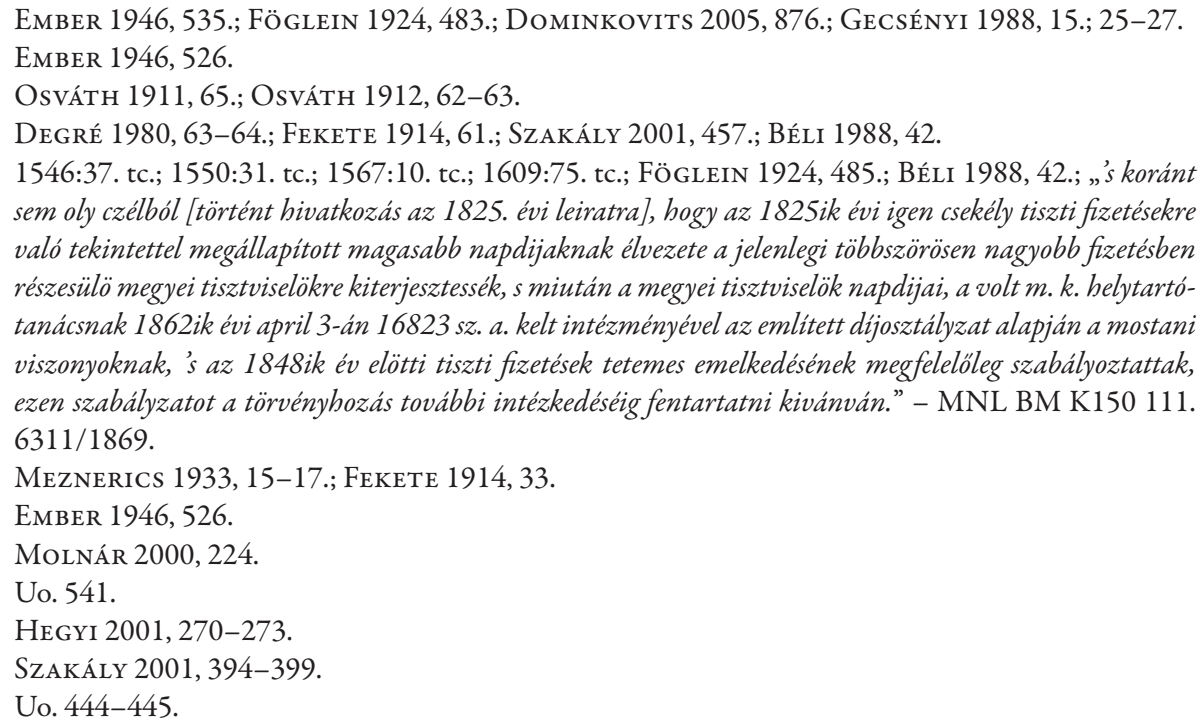
sem oly czélból [történt hivatkozás az 1825. évi leiratra], hogy az 1825ik évi igen csekély tiszti fizetésekre való tekintettel megállapitott magasabb napdijaknak élvezete a jelenlegi többszörösen nagyobb fizetésben részesülö megyei tisztviselökre kiterjesztessék, smiután a megyei tisztviselök napdijai, a volt m. $k$. helytartótanácsnak 1862ik évi april 3-án $16823 \mathrm{sz}$. a. kelt intézményével az emlitett dijosztályzat alapján a mostani viszonyoknak, 's az 1848ik év elötti tiszti fizetések tetemes emelkedésének megfelelöleg szabályoztattak, ezen szabályzatot a törvényhozás további intézkedéséig fentartatni kivánván." - MNL BM K150 111. $6311 / 1869$. 
tisztikart, akik ellátták a török uralom alatt álló területeken is a vármegyei kötelezettségeket. ${ }^{162}$

\subsection{A szolgabírói hatáskörök átalakulása}

A 16. századtól a sedria vált a vidéki igazságszolgáltatás legfontosabb fórumává a központi bíróságok és a vándorbíráskodás megbízhatatlansága miatt, ${ }^{163}$ amelyhez hozzájárult, hogy az 1495:15. tc. kivételesen a vármegyei törvényszékeknek is lehetőséget biztosított a fópapok és bárók ügyeinek elbírálására. A vármegye ítélkezési fóruma nem állandó bíróságként müködött. A vármegyei törvényszékek tagjai a Mohács utáni időszakban is a szolgabírák és a már tisztviselőként rendszeresített esküdtek maradtak az alispán mellett. A korszak kutatói szerint a 16-17. században a négy szolgabíró és az esküdtek megjelenése kötelező a sedrián. ${ }^{164}$

A szolgabírák és az esküdtek feladatainak megnövekedésével azonban szükségessé vált tehermentesítésük, amelyet az 1613:24. tc. orvosolt. Ez a jogszabály kimondta, hogy a rendes esküdtek mellett a közgyülés által a vagyonosabb nemesek közül választott rendkívüli esküdtek (törvényszéki ülnökök) is részt vehetnek a vármegyei törvényszéken. ${ }^{165}$ Az új tisztség betöltői csupán a sedria munkáját segítették, amely munkájukért napidíjra voltak jogosultak. Az elnevezésük a 18. században táblabíró lett, ${ }^{166}$ amely időszaktól viszont már a föispánt illette meg a kinevezésük joga. ${ }^{167} \mathrm{~A}$ vármegyei törvényszékeken ezt követően már nem volt köteles mindegyik szolgabíró és esküdt megjelenni, míg a 19. századra már csak egy szolgabírónak kellett részt vennie az esküdtjével a sedrián. ${ }^{168}$

Az alispáni szék és a szolgabírói szék is a vármegyei törvényszék tehermentesítésére jött létre, amelyektől a sedriához lehetett fellebbezni. A szolgabírói széki jogszolgáltatás különleges vármegyei gyakorlatként már a 15. század második felében megjelent Pest vármegyében, amely a sedriától kapott alkalmi felhatalmazások alapján, a kisnemesi igényeknek megfelelő sommás eljárásokat folytathatott le. ${ }^{169}$ Országos szinten a 16. században a szolgabírák igazságszolgáltatási hatáskörét törvényileg a jobbágyok költözésével kapcsolatos ügyekre és 20 forintig a világos adóssági ügyekre vonatkozóan rögzítették. ${ }^{170}$ Béli Gábor szerint az új vármegyei fórum működésére vonatkozóan több vármegye is statútumokat alkotott, tehát a szabályozás megjelent a vármegyei gyakorlatban is. ${ }^{171} \mathrm{~A}$

\footnotetext{
162 SZAKÁly 2001, 449-450.

163 
szolgabírói ítélőszék hatáskörét a vármegyei igazságszolgáltatás jelentős fórumaként az 1729:35. tc. szabályozta, amelyben a kisebb értékű magánjogi perekben nyert eljárási jogosultságot. ${ }^{172}$ A büntetöügyekben pedig a „kihágási” jellegü ügyekben szabhatott ki büntetéseket. ${ }^{173} \mathrm{~A}$ szolgabírák bíráskodási hatáskörüket a törvény értelmében az egész vármegyére kiterjedően és nem csupán saját járásukban gyakorolhatták. A szolgabírói ítélőszék működése kapcsán azonban Bató Szilvia megállapította, hogy a 19. században a joggyakorlat eltért a törvényi szabályozástól, és a szolgabírák illetékességi területe csupán saját járásukra terjedt ki. ${ }^{174}$

A szintén az 1729:35. tc. által létrehozott alispáni széken az elnöklő alispán mellett a szolgabírák és az esküdtek vettek részt bírótársként. ${ }^{175} \mathrm{Az}$ úriszéken a vármegyéket a szolgabírák és esküdtjeik képviselték a „törvényes bizonyság” biztosítása céljából, akik jelentést tettek a vármegyei közgyülésnek és az úriszéktől a vármegyéhez fellebbezett iratokat eljuttatták a sedriához. ${ }^{176} \mathrm{~A}$ nemesek ügyei mellett a megyei statútumok alapján az úriszék tartását elmulasztó földesurak helyett a 18. század elejétől gyakran a szolgabírák jártak el a jobbágyok ügyeiben is. Ez főként a kisnemesek jobbágyai esetében vált gyakorlattá. ${ }^{177}$

Az ítélkezési tevékenység mellett a szolgabírák a törvénykezést segítő részfeladatokat is ellátták. A szolgabírák esküdtjeikkel a bíróság elé idézhették a peres feleket, bírói megintéseket hajthatták végre, ${ }^{178}$ valamint hatáskörükbe tartozott a tanúkihallgatások lefolytatása vagy a bizonyítékok felvétele. ${ }^{179}$

A hazai törvénykezési szervezet reformjával az 1791:67. tc. által kiküldött kodifikációs bizottságok az 1827:8. tc. értelmében megújított munkái közül a „törvényes dolgokról” készített foglalkozott. ${ }^{180} \mathrm{E}$ tervezet az úriszéken törvényes bizonyságként részt vevő tisztviselőknek szavazati jogot kívánt biztosítani, amelyet egy értékes újításnak tartott a Zala megye által készített véleményezés, tehát ez a korszakban nem volt számukra minden vármegyében biztosítva. ${ }^{181} \mathrm{~A}$ tervezet emellett felvetette az alispáni és szolgabírói ítélószékek eltörlését és hatásköreik megyei törvényszékhez utalását. ${ }^{182}$ Zala vármegye ezt nem támogatta, mivel véleménye szerint mindkét ítélőszék megfelelő tekintéllyel rendelkezett a feladatok ellátásához és eltörlésük a megyei törvényszékek túlzott leterhelését okozná. ${ }^{183}$

172 BÉLI 2000, 288.; VARGA 1996, 100.

173 Meznerics 1933, 27-29.; 1729:22. tc.

174 BATó 2010, 23.

175 MOLNÁR 2000, 101.

176 Ember 1946, 538.; Meznerics 1933, 31.; Degré 2004c, 118-119.; 1609:29.tc.; 1613:23. tc.; $1729: 28$ tc.

177 DEGRÉ 2004c, 109; 112.

178 1807:8. tc.

179 1609:29.tc.; 1613:23. tc.; 1723:30. tc.; FöGLEIN 1924, 491.

180 Az 1827:8. tc. értelmében egy bizottságot küldtek ki, amelynek 9 albizottsága tárgyalta az 1791:67. tc. alapján elkészült kodifikációs tervezeteket. Az így átvizsgált anyagokat utána az országos bizottság vitatta meg, Ennek eredményét pedig kinyomtatták, hogy ezáltal biztosítsák a közvélemény számára az operátumok véleményezését. A tervezetek azonban nem kerültek az országgyűlés elé. BÉLI 2000, 285.; Homoki-NaGY 2004, 15-17.

181 MOLnÁr 2000, 95.

182 BÉLI 2000, 286-287.

183 MolnÁr 2000, 98-99.; BÉLI 2000, 288-289. 
A 16. századtól fokozatosan bővültek a megyék által ellátandó feladatok, ${ }^{184}$ amelynek következményeképpen a járási tisztviselők leterheltsége is folyamatosan növekedett. Erre az időszakra tehető, hogy az igazgatási tevékenységek végzése terén a járások a szolgabírák illetékességi területeivé váltak. Ennek egyértelmű jele, hogy az 1647:153. tc. és az 1649:86. tc. bizonyos járásokat a szolgabíráik nevével azonosított. A jobbágyok költözködési jogának biztosítása is a vármegye feladata volt, amelyhez kapcsolódó eljárás lebonyolítását az 1504:16. tc. a szolgabírákhoz utalta. A processzust az 1547:27. tc. ismételten megerősítette, miután a jobbágyok szabad költözési jogukat visszanyerték. ${ }^{185}$ A szolgabíró feladata volt a jobbágy és földesura közötti elszámolás lebonyolítása és a jobbágy költözésének biztosítása. ${ }^{186}$ A szolgabírák a jobbágyigazgatással kapcsolatos hatásköreiket a 19. században is megőrizték. ${ }^{187}$

Emellett a szolgabírák megtartották a Mohács előtti korszakból az adóbevételekkel kapcsolatos feladataikat is, ugyanis mind az adók kirovásában, mind az adók beszedésében részt vettek esküdtjeikkel az ezzel megbízott hivatalnokok mellé rendelve. ${ }^{188} \mathrm{~A}$ másik közteherrel, a közmunkákkal kapcsolatos teendőket, ${ }^{189}$ valamint a katonaállítás és a katonatartás koordinálását is a szolgabírák végezték. ${ }^{190}$ Béli Gábor kutatásai emellett rámutattak arra, hogy a 18. század elejétől Baranya megyében már az útonállók és a rablók megfékezése is a szolgabírák hatáskörébe tartozott. ${ }^{191}$ A szolgabíráknak a levelesítés során végzett segítő tevékenységéből alakulhatott ki azon általános gyakorlat, miszerint a vármegyékben a közbiztonság fenntartásával járó feladatokat a szolgabírák látták el. ${ }^{192}$ A mezei rendőrségről szóló 1840:9. tc. ezt a hatáskört bővítette azáltal, hogy a károsító cselekmények kinyomozása és elbírálása is a feladatukká vált.

A gyakori tüzesetek miatt a szolgabírák ügyeltek a lakosság tüzhasználati szokásaira is. A járás első embere emellett végrehajtotta a fö- és alispán utasításait is. ${ }^{193} \mathrm{~A}$ szolgabírák feladata volt ennek köszönhetően a járásukban az alispán parancsára a vármegyei közgyűlés és törvényszék időpontjának kihirdetése, valamint a közgyűléstől igazolatlanul távolmaradók bírságolása. ${ }^{194}$ A szolgabírák aktív közreműködésével történtek a vármegyei tisztújítások is. Ehhez ugyanis a nemesek összeírására volt szükség, amelyre járásonként került sor. Ezeket általában egy háromtagú bizottság, a járás szolgabírája két esküdttel vagy táblabíróval végezte. A szavazatokat összegyüjtő bizottság is járásonként szerveződött. ${ }^{195}$ A vármegyei közgyüléseken a szolgabírák kötelesek voltak megjelenni.

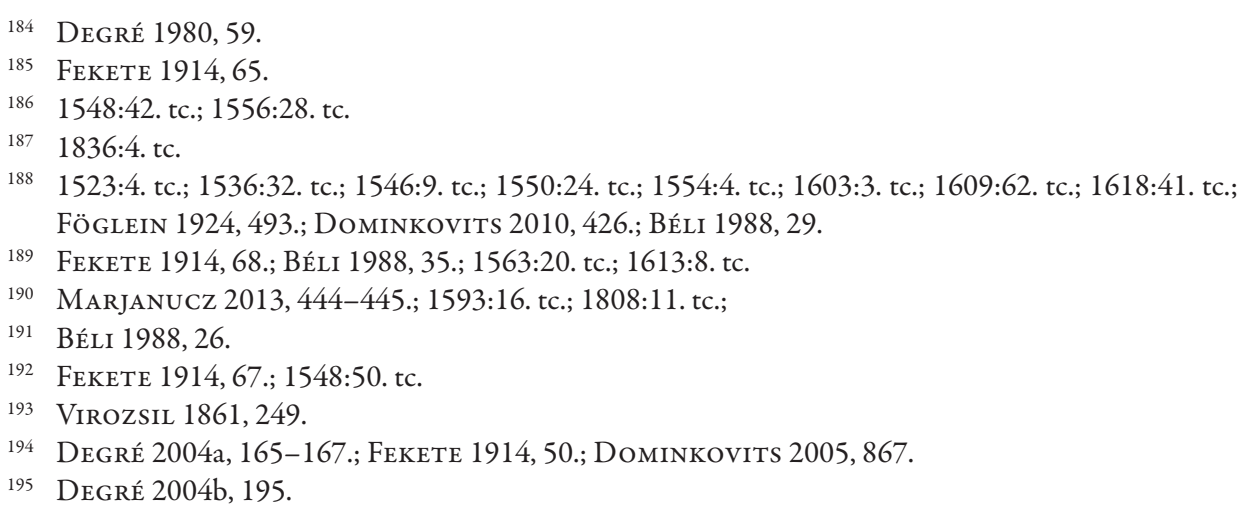


Zsoldos Ignác a szolgabírói hivatalról írt klasszikus művében ötvenhárom olyan közigazgatási feladatot gyűjtött össze, amelyek ellátása csupán a járásuk vagy a kerületük területén tartozott a szolgabírák hatáskörébe. ${ }^{196}$ Összességében tehát elmondható, hogy a vármegye a járási szinten végrehajtandó igazgatási teendőket a szolgabírákhoz utalta. ${ }^{197}$

\subsection{A szolgabírák segítői a járási feladatok ellátásában}

A vármegyei gyakorlatban megőrzött esküdti intézményt I. Ferdinánd rendelkezései rendszeresítették újra az egész ország területén a sedrián megjelenő bírótársakként. Számukat - a megye kiterjedésétől függően - hat és tizenkettő között határozták meg. ${ }^{198}$ A 16. században az esküdtek megmaradtak a sedria ítélkezési tevékenységének résztvevőiként, akik kötelesek voltak megválasztásuk esetén egy éves mandátumukat elvállalni. ${ }^{199}$

A rendes esküdt ülnökök a 17. század elejétől fokozatosan a szolgabírák segédjeivé váltak a törvénykezési és a közigazgatási feladatok ellátásában. ${ }^{200} \mathrm{Az}$ egyes szolgabírák és esküdtek így együttesen jártak el hivatalos működésük során. ${ }^{201}$ Zsoldos a következőképpen fejezte ki a két tisztség összetartozását: „Sz[olga]biró és Eskütt két test, de egy léleknek tekintetik törvényileg." ${ }^{202}$ A tisztség előzményeként a Mátyás nagyobb dekrétumában bevezetett esküdti pozíció tekinthetö. ${ }^{203}$

A vármegye az ügyviteli terhek függvényében változó számú esküdtet választhatott, akik önálló intézkedésre nem voltak jogosultak és rendszeres fizetéssel is csak néhány vármegyében rendelkeztek $\mathrm{Az}$ általuk ellátott feladatok utáni napidíj biztosította a szegényebb nemesek közül kikerülő esküdtek jövedelmét. ${ }^{204}$ Degré Alajos kétségbe vonta az esküdtek közgyűlés általi választását, mivel a Zala vármegyei jegyzőkönyvek alapján arra a megállapításra jutott, hogy főispáni kinevezés alá estek. ${ }^{205}$ A 19. század első felétől azonban már minden tisztviselőt, így az esküdteket is a vármegyei közgyűlés választotta. ${ }^{206}$ A reformkorban már rendes („rendszerént való”) és tiszteletbeli (Pukynál becsületbeli) esküdtet is megkülönböztettek. A rendes esküdtek az egyes szolgabírák mellé rendelve állandó jelleggel teljesítették szolgálatukat, ezzel szemben a tiszteletbeli esküdtek meghívás alapján az egyes ügyekben vettek részt a szolgabírák feladatainak ellátásában. ${ }^{207}$ Erdély-

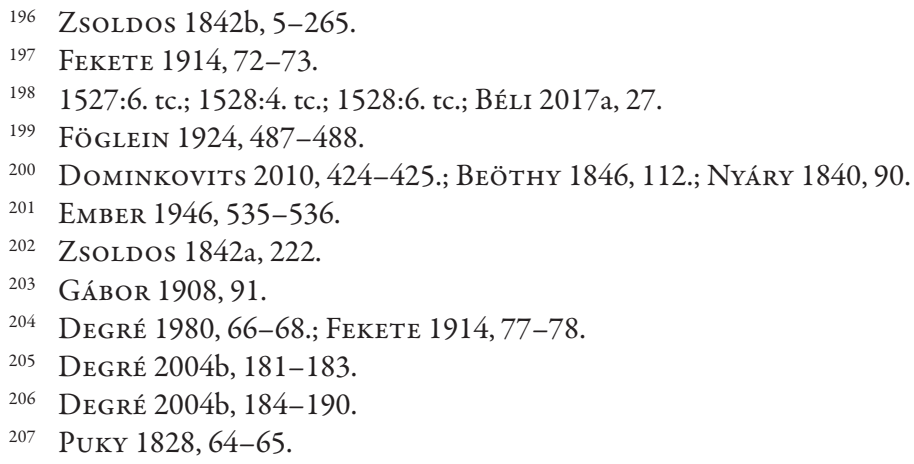


ben csak a 17. század elején jelentek meg a választott esküdtek, akik a sedria társbírói maradtak, és nem váltak a szolgabírák segédeivé a közigazgatási feladatok ellátásában. ${ }^{208}$

A szolgabírói feladatok szaporodásával a 15. században a nagyobb vármegyékben megjelentek az alszolgabírák is, ${ }^{209}$ amely tisztség a szolgabírák mellé rendelve a megyei tisztikar szakszerüvé válásának jeleként a 18. század első felében válik jellemzővé. ${ }^{210} 1753$ ból van ismert adat arra nézve, hogy már különálló kerülettel rendelkeztek a járáson belül. ${ }^{211} \mathrm{Az}$ alszolgabírák a vármegyei közgyủlés által választott tisztviselők voltak. ${ }^{212}$ Az alszolgabírák megjelenésével a szolgabírák neve föszolgabíróvá változott. ${ }^{213}$ Puky adott magyarázatot művében az elnevezésbeli különbségre. Eszerint a járás élén állt a főszolgabíró, aki a saját kerületének ügyei mellett felelt a járási feladatok ellátásáért és a vármegyével, valamint az alispánnal közvetlen kapcsolatot tartott a járással kapcsolatos ügyekben. Ezzel szemben az alszolgabírák a föszolgabíró ellenőrzése alá tartoztak és csupán az adott kerületre vonatkozó feladatok ellátása tartozott a hatáskörükbe. ${ }^{214}$ Erre a felosztásra példáként szolgál Pest vármegye, amely 1840-ben öt járásra oszlott, amelyeken belül egyenként három-három kerületet különítettek el. Ezek élén álltak a fö- és alszolgabírák, a kerületeket a tisztségviselők osztották fel egymás között. ${ }^{215}$

\subsection{A járások és a szolgabírák összekapcsolódása}

A járások a 16. században váltak adószedési körzetekből fokozatosan a megyék közigazgatási egységeivé. Ennek első nyomait Tringli István egy 1521-ből származó Nógrád megyei vizsgálatról szóló oklevélben fedezte fel. ${ }^{216} \mathrm{~A}$ vármegye kisebb közigazgatási egységekre bontása már általánossá vált a 16 . századra, bár az egységes terminológia még hiányzott. A vármegye alatti közigazgatási szintet jelölték járásként és kerületként is, további nehézséget okozott, hogy esetenként a kerületeket további járásokra is bontották. A kerület elnevezés főként Erdélyben vált általánossá. ${ }^{217} \mathrm{~A}$ szolgabírák eljárása nem korlátozódott szigorúan csupán a saját járásuk területére, bár főként ennek a közigazgatási egységnek az ügyeit intézték. A járások, kerületek területének meghatározása szintén a vármegyei közgyülés hatáskörébe tartozott. ${ }^{218}$

A kora újkorban a szolgabírák száma a középkorban kialakult szokás szerint a legtöbb vármegyében négy volt, míg egyes vármegyékben kettő, amely szabályszerűségnek

EMBER 1946, 536.

Holub 1929, 153.

Degré 1980, 66.; Dominkovits 2005, 856-857.; Dominkovits-HorvÁth 2011, 26.

DEGRÉ 1980, 66.

Holub 1929, 153.; Ember 1946, 41.; BÉLi 1988, 41.

STIPTA 1998c, 476.

PukY 1828, 56-62.; RÉCSI 1861, 482.; MeZnerics 1933, 11.

NYÁRY 1840, 69-70.

TringLi 2009, 515.; az oklevél szövege publikálva: SzABÓ 1909, 172.

W. Kovács 2010, 36.

EMBER 1946, 531. 
megfelelően ezzel megegyező számú járás jött létre a vármegyékben. ${ }^{219}$ A 16 . század végén és a 17. század elején azonban ez a szabályszerűség megbomlott és a szükségleteknek megfelelően változott a járások száma a vármegyékben, ${ }^{220}$ Erdélyben azonban megmaradt a szolgabírák számának megfelelő két-két járásra való felosztás. Erdélyben a járások nemcsak saját szolgabírákkal és esküdtekkel rendelkeztek, hanem önálló föispánt és alispánt is állítottak az élükre. ${ }^{221}$

A közgyűlés a szükségleteknek megfelelően a szolgabírák és a járások számát csökkenthette és növelhette. Ezen közigazgatási egységekből kiemelték a nagyobb összefüggő uradalmak területét, amelyek esetében a szolgabíró feladata csupán az uradalmi tisztekkel való együttműködésre korlátozódott. A járásoknak központja, székhelye nem alakult ki, azok jellemzően a szolgabírák lakhelyéhez igazodtak. ${ }^{222}$ A vármegyei közgyülés jellemzően a járás területén élő nemest választott szolgabírónak, vagy kötelezték a járáson kívül lakó megválasztottat a járás területére való költözésre. ${ }^{223} \mathrm{Az}$ újkorban jelent meg egységesen az a gyakorlat, hogy a járások önálló névvel rendelkeznek, amelyek általában a szolgabírák nevéhez, ritkábban a járás székhelyéhez vagy valamilyen tájnévhez igazodtak. ${ }^{224}$

A 19. században Puky Károly és Palugyay Imre már a vármegyék közös jellemzői között említette, hogy a járásokat további kerületekre osztják fel. ${ }^{225}$ Véleményük szerint a vármegyék az egyes járásokat általában két vagy három kerületre bontották.

\subsection{A rendi kori szolgabírák jellegzetességei és a vármegyei közigazgatás modernizálása}

A szolgabírák a korszakban egyértelműen a közigazgatás központi szereplőjévé váltak. A járásra vonatkozó igazgatási teendők ellátása immáron a szolgabíráktól egész embert kívánt a korábbi kiegészítő, időszakos tevékenységként elvégezhető hivatal helyett. Puky Károly a szolgabírákat a vármegyei tisztségviselők „ranglétráján” a főispán, az alispán és a másodalispán mögé sorolta, sőt a föjegyzői tisztséget is elismertebb pozíciónak tartotta, így a a fószolgabírákat a fóadószedővel, valamint a tiszti föügyésszel tartotta azonos rangúnak. ${ }^{226}$ A szolgabírói hivatal legfontosabb jellemzőit a polgári átalakulást megelözően az alábbiakban lehet összefoglalni: a járások élén álló választott tisztviselő volt, aki az esküdttel együttműködve végezte el a rá háruló közigazgatási és igazságszolgáltatási feladatokat.

Tringli 2009, 505.; Meznerics 1933, 10.

GeCsényi 1988, 17.; BÉLi 1988, 41.

221 Bicsok et al 2003, 80.; 352.; Pokoly 1901, 352.

222 Degré 1980, 67.; TAKÁCS 1963, 27.

223 FeKeTE 1914, 60.

224 C.Tóth-Tringli-Draskóczy 2005, 519.; Degré 1980, 65.; Fekete 1914, 60.; Szakály 2001, 457-462.; Dominkovits 2005, 871.; 1647:129. tc.; 1681:7. tc.

225 Puky 1828, 5.; 54-55.; Palugyay 1844a, 163-164.

226 Puky 1828, 75.
} 
A vármegyei közigazgatás megreformálására elöször II. József tett kísérletet, aki az egész Habsburg Birodalom átfogó reformjára törekedett. A rendi önkormányzat működésének megszüntetését 1786-ban mondta ki rendeletében. ${ }^{227} \mathrm{Az}$ átszervezés azonban kérészéletünek bizonyult, mivel 1790-ben visszaállította a korábbi önkormányzati struktúrát az új uralkodó, II. Lipót. ${ }^{228}$ Ennek köszönhetően az 1848. évi jogi forradalom időszakában megalkotott áprilisi törvények ismételten a vármegyei közigazgatás átalakítását és a polgári állam alapját képező közjogi keretek megteremtését célozták. Az államszervezet kialakításakor az országgyűlésre és a kormányra vonatkozó rendelkezések komolyabb viták nélkül megszülettek, azonban a közigazgatási törvények megalkotása során komoly elvi nézetkülönbségek kerültek felszínre. Az ország vezetését ellátó politikai erők nem tudták eldönteni, hogy mely alapelvek mentén építsék fel a polgári Magyarország közigazgatási szervezetét. A vármegyék különös jelentőségét adta, hogy a magyar történelmi alkotmány egyik lényeges eleméről, a magyar függetlenség védbástyájáról kellett rendelkezniük a törvényhozóknak, amelyet a magyar államiság alapkövének tekintettek. ${ }^{229} \mathrm{Az}$ egyértelmü volt, hogy a jobbágyfelszabadító rendelkezéseket a hagyományos összetételü vármegyei közgyülésekkel nem lehet végrehajtani. A végleges megegyezés hiánya és a ráirányuló fokozott érdeklódés miatt az 1848:XVI. tc. azonban csak ideiglenesen intézkedett a vármegyék szervezetéről, és a jövendő törvényhozás feladatául szabta az erre vonatkozó törvények megalkotását. ${ }^{230} \mathrm{~A}$ városok 1848-ban részletesebb, de szintén keretjellegü szabályozást nyertek az 1848:XXIII. tc.-ben. ${ }^{231}$

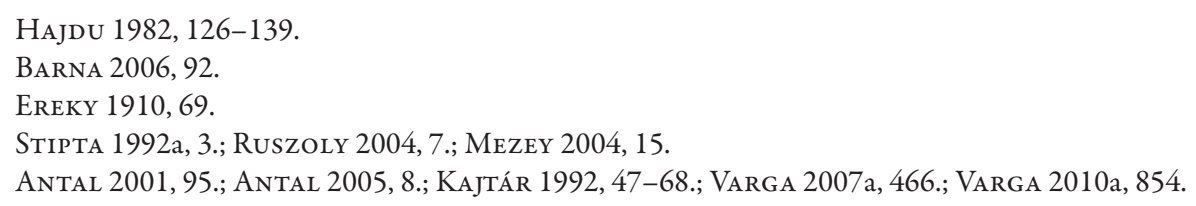




\section{A NEOABSZOLUTizmUS \\ SZOLGABÍRÓI HIVATALA}

\subsection{A közigazgatási szervezet átalakulása a szabadságharc leverését követően}

A szabadságharc kezdetét követően 1848. október 3-án V. Ferdinánd leiratában Magyarországon és Erdélyben hadiállapotot rendelt el, így felfüggesztette az önkormányzati szervek müködését. ${ }^{232} \mathrm{Az}$ osztrák hadak vezetésével megbízott Alfred Windisch-Grätz herceg így az általa éppen uralt területeken 1849 januárjától átvette a közigazgatás irányítását. A törvényhatóságok élére királyi biztosokat állított, amely mellett a megyei tisztikarok továbbmüködhettek. ${ }^{233} \mathrm{Az}$ olmützi alkotmány 1849 márciusában nem léphetett hatályba Magyarországon az ostromállapot következtében.

1849 júniusában báró Julius Jacob von Haynaut nevezte ki Ferenc József a magyarországi és erdélyi császári hadak fövezényletére, valamint a kormányzati feladatok gyakorlására, mellé pedig Karl Geringer bárót helyezték, akit császári biztosként a polgári ügyek vitelére rendeltek. ${ }^{234}$ Geringer ekkor megkezdte a megyék feletti polgári kerületek kialakítását, amelyek alapulvételével hozták létre az ország katonai kerületeit. A császár által októberben jóváhagyott reformok célja az igazságszolgáltatás és a közigazgatás elválasztása volt az államszervezet minden szintjén, valamint az egyszemélyi felelős vezetés megteremtése. A megyék politikai igazgatását így megyei fönök néven kormánybiztos vezette, akit a kerületi fóbiztos alá rendeltek. A megyék területét pedig járásokra osztották, amelyek élén a járásbeli biztos állt ,igazgató szolgabíró” címmel. ${ }^{235}$ Munkájukért a megyefönöknek tartoztak felelősséggel. Jelentős változásokat hozott ez a szabályzat a korábbi alsó középszintű közigazgatásban, mivel a járási hivatalnokoktól elvonták az igazságszolgáltatási és adóügyi teendőket. Emellett Magyarországon elöször meghatározták a járások székhelyét, ahol kötelesek voltak a járási tisztviselők lakni. Ezeket a kereskedelem és ipar érdekeinek figyelembevételével határozták meg. Az újonnan létrehozott állami állásokat pályázat útján töltötték be.

1850 nyarán a külpolitikailag kellemetlenné vált báró Julius Jacob von Haynaut az uralkodó leváltotta, és a bécsi minisztertanács 1850 tavaszától már a katonai és polgári kormányzat elválasztásán dolgozott. E munkálatok során egyértelmű volt, hogy az 1849ben lefektetett alapokat veszik kiindulópontként. 1850 szeptemberében így szervező rendeletet bocsátottak ki, amelynek értelmében a helytartó átvette a közigazgatási ügyek intézését, a közigazgatási szervezet alsóbb szintjei azonban változatlanok maradtak. ${ }^{236}$

\footnotetext{
SAshegyi 1965, 15-16.

Uo. 24-25.

SzABAD 1979, 454.

SZITA 1983, 329-330.

DEÁK 2009, 40.
} 
Ekkor megvalósult az igazságszolgáltatás és közigazgatás elválasztása a járási szinten is. A hadiállapotot azonban fenntartották a közigazgatás rendezését követően is.

\subsection{A birodalmi, egységes közigazgatási szervezet kiépítése}

Az olmützi alkotmány helyett a császár kihirdette 1851 végén a szilveszteri pátenst, amellyel egyidőben kidolgozták az újonnan létrehozandó, az egész birodalomban egységes közigazgatási szervezet alapelveit. ${ }^{237}$ Ennek értelmében Magyarországon a végleges közigazgatási szervezet létrehozását célozták, amelyet egy 1852 januárjában felállított bizottságra bíztak. E szerv munkájának köszönhetően az 1853. január 10-én kelt legfelsőbb császári elhatározás, amelyet az 1853. január 19-én kelt belügyi, igazságügyi és pénzügyi minisztériumi rendelet tartalmazott, a korábbiakhoz hasonlóan alakította az ország közigazgatási szervezetét, azonban a járások szintjén egyesítették az igazságszolgáltatási és közigazgatási teendőket a „vegyes” járási hivatalok kialakításával. ${ }^{238}$ Ez szabályozta először teljeskörűen Magyarország közigazgatási szervezetét, azonban a magyar hagyományokat teljes mértékben figyelmen kívül hagyta. Ennek oka a jogeljátszás elmélete („Verwirkungstheorie"), amely szerint Magyarország törvényes uralkodója elleni felkeléssel elveszítette jogát a függetlenségre. ${ }^{239} \mathrm{~A}$ bécsi kormányzat ennek segítségével teremtett jogalapot a magyar közigazgatási szervezet beolvasztására a Birodalomba. Az országot annak területi integritását megbontva koronatartományként kormányozták, amelynek élén a helytartóság állt. ${ }^{240}$ Alájuk rendelve a helytartósági osztályok által irányított öt kormányzati kerület volt, ${ }^{241}$ amelyeken belül fennmaradhattak némi területrendezést követően a megyei hatóságok, ${ }^{242}$ azonban csupán az államigazgatás végrehajtási közegeivé váltak, önkormányzati hatásköreik elvonását fenntartották. ${ }^{243} \mathrm{~A}$ megyei hatóságok alá rendelt alsó középszintű igazgatási szint a szolgabírói hivatal volt, amelynek élén a szolgabíró állt. ${ }^{244}$

Az 1853. január 10-én kelt szervező rendeletet csak fokozatosan léptették hatályba „felülről lefelé” haladva. A helytartóság és a megyék létrehozását követően került csupán sor az újonnan szervezett járási hivatalok felállítására. A rendelet azonban a közigazgatási szervezet kiépítését részleteiben nem szabályozta. A járási szervezet kapcsán a szolgabírói járások számának, határainak és székhelyeinek megállapítását, valamint a szolgabírói hivatalok személyzetének, létszámának és fizetésének meghatározását a kerületek irányítását végző helytartósági osztályokban felállítandó bizottságokra bízta.

\footnotetext{
Somogyi 1981, 56.

Olechowski 2014, 198.; LeHner 1992, 196.; Lehner 1995, 20., 24. A’ bel-, igazság- és pénzügyi ministereknek 1853-diki január 19-kén kelt rendelete.

239 Friedjung 1908, 373-374.

240 Csorba 1998a, 298.

241 PN 1853/861. 1.; BH 1853/18. 1-2.

242 BENEDEK 2006, 240.

243 Szita 1983, 332-334.; Sashegyi 1981, 111-112.; KajtÁr 2004, 27.

244 von Stubenrauch 1856, 29.
} 
Ennek vezetését a helytartósági osztály elnöke látta el, tagjai pedig két-két közigazgatási és igazságügyi hivatalnok, valamint egy pénzügyi tisztviselő voltak. ${ }^{245} \mathrm{~A}$ bizottság felépítése is arra mutatott, hogy a járásokban e három terület hatásköreit egyesítették. A szolgabírói hivatalok szervezésekor a területi beosztás revízióját is elvégezték e szervek. Munkájuk elhúzódott, így a járási hivatalok csupán 1854. április 29-ével állhattak fel, amikor a járások székhelyeit rendeletben szabályozták. ${ }^{246} \mathrm{Az}$ új közigazgatási szervezet kiépítését követően, 1854. május 1-jén megszüntették a hadiállapotot Magyarországon, így a bécsi kormányzat ezt tekintette a közigazgatás végleges rendezésének. ${ }^{247}$ Emellett érdemes megjegyezni, hogy Erdély szintén külön koronatartományt alkotott, mivel az áprilisi törvények unióra vonatkozó rendelkezéseit nem alkalmazta az osztrák központi kormányzat. Ennek megfelelően a járási szervezet végleges megszervezéséről Erdélyben szintén 1854-ben megjelent rendeletek gondoskodtak külön az anyaországtól.

A szolgabírói hivatalok felállítása tehát hosszabb előkészítést vett igénybe, amelyet néhány helyi példával kívánok szemléltetni. A közelgő hivatali átszervezésre hivatkozva 1853 novemberében a helytartósági osztály elnöksége megkereste a Csanád megyei fönökséget, hogy adjanak felvilágosítást arról, hogy milyen helyiségek állnak rendelkezésre a Battonyán felállítandó szolgabírói hivatal számára. ${ }^{248} \mathrm{~A}$ Csanád megyei fönökséget 1854. január 11-én tájékoztatta szintén a helytartósági osztály elnöksége a nagyváradi cs. kir. kormányzati kerületben történő megyei és járási átszervezésekről. ${ }^{249} 1854$. január 16-án ennek köszönhetően a megyehatóság utasította a járási hivatalokat, hogy az iratok lajstromozását olyan módon végezzék, ami megkönnyíti majd az iratok átadását az újonnan felállítandó alsó középszintű közigazgatási hivataloknak. ${ }^{250} \mathrm{~A}$ Csanád megyei fönökség 1854 januárjának végéig működött, január 24-től az iratok lezárásával foglalkoztak, szerepüket a gyulai megyehatóság vette át Csanád és Békés megye egyesítése miatt. ${ }^{251} \mathrm{~A}$ Csanád megyei hatóság értesítette április 7 -én a makói szolgabíróságot, hogy az új járási szervezet április 29-én fog felállni és a német hivatali nyelv bevezetését alsó középszinten elhalasztották. ${ }^{252}$ A makói járás esetében a jegyzőkönyvet április 20-án már lezárták, hogy április 29-éig megfelelő időt biztosítsanak a járásbírósági iratok átadására és az új hivatalnokok számára a beköltözésre. ${ }^{253} \mathrm{Az}$ átalakításoknak köszönhe-

245 PN 1853/862. 1-2.; BH 1853/19.87.

246 PN 1854/1229.3-4.; BH 1854/394. 2223-2224. p.

247 PN 1854/1243. 1.; BH 1854/409. 2304.

248 MNL CSMLSZ IV.B. 151. a. Csanád Megye Cs. Kir. Megyehatóságának iratai, 5. k., - 1853. Elnöki Beadványi Jegyzőkönyv 529.

249 MNL CSMLSZ IV.B. 151. a. Csanád Megye Cs. Kir. Megyehatóságának iratai, 6. k., - Elnöki Jegyzőkönyv 1854 ik évre 13.

250 MNL CSMLSZ IV.B. 151. a. Csanád Megye Cs. Kir. Megyehatóságának iratai, 6. k., - Elnöki Jegyzőkönyv 1854 ik évre 16.

251 MNL CSMLSZ IV.B. 151. a. Csanád Megye Cs. Kir. Megyehatóságának iratai, 6. k., - Elnöki Jegyzőkönyv 1854 ik évre 23.

252 MNL CSMLSZ IV.B. 162. a. Makói Cs. Kir. Szolgabíróság iratai, 6. k., - Csanád Megye Makói Járási Elnöki Jegyző Könyv az 1854iki Közig Évre 65-66.

253 MNL CSMLSZ IV.B. 162. a. Makói Cs. Kir. Szolgabíróság iratai, 6. k., - Csanád Megye Makói Járási Elnöki Jegyző Könyv az 1854iki Közig Évre 70. 
tően megszűnő nagylaki szolgabíró pedig április 22 -én fejezte be munkáját. ${ }^{254} \mathrm{~A}$ makói szolgabíró jelentette, hogy április 20-án hivatalát átvette, a közigazgatási iratokat pedig április 21-étől 23-áig átadták számára, viszont ezzel a nagylaki járás szolgabírója adós maradt. ${ }^{255}$ Ezekben a napokban a makói járásban alkalmazott új hivatalnokok, valamint az új hivatali pecsétek is megérkeztek. ${ }^{256} \mathrm{~A}$ levéltári források igazolták, hogy az új hivatalok április 29-én kezdhették meg müködésüket. A hivatali jegyzőkönyv is azt bizonyította, hogy jelentős változást nem hozott a közigazgatási szervezet felépítésében a szolgabírói hivatalok 1854. évi felállítása, mivel a korábban megkezdett jegyzőkönyvet folytatólagosan vezette a szolgabíró.

\subsection{A definitívum szolgabírói hivatala}

A neoabszolutizmus korában a végleges közigazgatási rendezést követően (definitívum) Magyarországon felállított járási hivatalok egységesen a szolgabírói hivatal elnevezést viselték. Ez Ferenc József császár 1851. december 31-én kiadott legfelsőbb kabineti iratában, a szilveszteri pátenssel egy időben kiadott uralkodói leiratban meghatározott elvek Magyarországon történő végrehajtásaként valósulhatott meg. A leirat 4. és 5. pontja foglalkozott ugyanis a koronaországokban felállítandó járási hivatalokkal. A 4. pontban lefektetett elvnek megfelelően az alsó szintű közigazgatási feladatokat ellátó szerv megtarthatta a történeti elnevezését, így Magyarországon szolgabírói hivatalnak nevezték. ${ }^{257}$ Ezzel kívántak a lakosság szemében az új államszervezeti megoldásoknak legitimációt biztosítani. A járási hivatalok így a császár centralizációs törekvéseinek megfelelően a teljes birodalomra kiterjedő egységes államirányítási szervezetrendszer részévé váltak, amelyek csak elnevezésükben térhettek el az osztrák örökös tartományokban kiépülő járási hivataloktól. ${ }^{258} \mathrm{Az}$ egyes járási hivatalokban összpontosították az igazságszolgáltatási, közigazgatási és adóbehajtási teendőket, így a hatalmi ágak elválasztásának elve nem érvényesülhetett. Emiatt nevezték a létrejövő alsó középszintű közigazgatási egységet „vegyes" járás hivatalnak. 259

Ez volt az első olyan rendelkezés, amely a magyar közigazgatás szervezetét azonos módon szabályozta, így a kerületi beosztással csonkított Magyarország alsószintü közigazgatási egységeinek, a járásoknak szervezeti felépítését, hatáskörét és működését is

\footnotetext{
254 MNL CSMLSZ IV.B. 165. a. Nagylaki cs. kir. Szolgabíróság elnöki iratai 1853, 1854 iktató 2.d. - Elnöki Rendeletek Jegyző Könyve Nagy Laki Járás részéről 1854ik évben

255 MNL CSMLSZ IV.B. 162. a. Makói Cs. Kir. Szolgabíróság iratai, 6. k., - Csanád Megye Makói Járási Elnöki Jegyző Könyv az 1854iki Közig Évre 82-83.

256 MNL CSMLSZ IV.B. 162. a. Makói Cs. Kir. Szolgabíróság iratai, 6. k., - Csanád Megye Makói Járási Elnöki Jegyző Könyv az 1854iki Közig Évre 86.; 89.

257 RÉCSI 1854, 28.

258 EReky 1939, 31.; 10. Verordnung der Minister des Innern, der Justiz und der Finanzen vom 19. Jänner 1853; 1853-diki január 19-kén kelt rendelet.

259 STIPTA 2018, 294.
} 
megszabta. Magyarországon így a Bach-korszakban az a különlegesség történt meg, hogy az önkényuralmi hatalomgyakorlás időszakában történt meg a rendi kori közigazgatás hozzáigazítása a modern kor elvárásaihoz. ${ }^{260}$

A közigazgatási szervezet a centralizáció elvén alapult. Ezen elv megnyilvánulásait legerősebben a szolgabírói tisztség elnyerési módjában tapasztalhatjuk. A neoabszolutizmus időszakában a vegyes bizottmány három föt javasolt a pozícióra a helytartóság egyetértésével, amelyek közül a belügyminiszter az igazságügyminiszter jóváhagyásával Bécsből nevezte ki a hivatalnokokat. ${ }^{261} \mathrm{~A}$ vegyes bizottmány egy közigazgatási és igazságszolgáltatási szakemberekből álló állandó bizottság volt, amelyet közigazgatási kerületenként helytartósági és kerületi fötörvényszéki tanácsosokból állították össze a helytartósági osztály elöljárójának elnöklete alatt. ${ }^{262}$ Ebben az esetben már a szolgabírák kinevezési módjából érzékelhető, hogy járási szinten az igazságszolgáltatási és közigazgatási teendők egyesültek. Ez a szabályozás nem hagyta meg a vármegye jogosultságai között a szolgabíró választását, hanem a kinevezési rendszer szerint határozta meg a tisztség betöltését. ${ }^{263}$

A korábbi partikuláris jellegü járási beosztást a korszakban felváltotta az egységes államigazgatási járási szint. A legtöbb koronatartományban a járási beosztást a központi kormányzat Bécsből rendelet útján határozta meg, így az erdélyi és a horvát koronatartományban is. ${ }^{264} \mathrm{~A}$ járások területét az egyes településekre lebontva megszabták. A magyar koronatartomány esetében a központi kormányzat rendeletben csak a járások székhelyét rögzítette. ${ }^{265} \mathrm{~A}$ megfelelő járási szervezet kiépítése céljából viszont a helytartóságban az egyes kerületekre nézve külön szervezési bizottságokat alakítottak, amelyeknek az volt a feladata, hogy a részletek vonatkozásában eljárjon a járások kialakítása során, így az egyes települések beosztása már ennek a szervnek a feladata volt. ${ }^{266} \mathrm{~A}$ járási székhelyeket tehát első alkalommal határozták meg az 1854ben kelt miniszteri rendeletek Erdélyben és az anyaország területén is, így biztosítva a helyhez kötött igazgatást. A nagyvárosokat kiemelték a járási szervezetből és önálló közigazgatási egységként a kerületi hatóság vagy a vármegyei hatóság, esetleg közvetlenül a kormány irányítása alá helyezték.

Az egységes alsó középszintű közigazgatási szervezet létrehozásához hozzátartozott, hogy a szolgabírói hivatal felépítését is egységesítsék. A szolgabíró munkáját segédek, tollnokok és írnokok segítették. ${ }^{267} \mathrm{~A}$ hivatali „ranglétrán” a legalacsonyabb pozíciót betöltő írnokokat a szolgabíró javaslatára a megyefönök nevezte ki. A tollnokok személyére a megyehatóság hármas javaslatot terjesztett a szolgabírák választásánál már említett

PAPr 2014, 157.

PN 1854/1261. 4.

24. A' bel-, igazság- és pénzügyi ministereknek 1853-diki január 19-kén kelt rendelete.

RÉCSI 1854, 278.

136. Verordnung der Ministerien des Innern, der Justiz und der Finanzen vom 3. Juni 1854.; 141. Verordnung der Ministerien des Innern, der Justiz und der Finanzen vom 4. Juni 1854.

85. szám. A’ bel-, igazság és pénzügyi ministeriumoknak 1854. april 6-kán kelt rendelete.

TuZa 2005, 351.

RÉCSI 1854, 70-94. 
vegyes bizottmány számára, amely a javasolt személyek közül betöltötte a tisztséget. A szolgabíró utáni legmagasabb pozíciót jelentő segédi állásra a belügyminiszter nevezte ki az igazságügyminiszterrel egyetértésben az alkalmas egyéneket a vegyes bizottmány révén összeállított és a helytartó által jóváhagyott három személyből. A segédszemélyzet számát a szervezési munkálatokra kerületenként, a helytartóság által létrehozott szervezési bizottság határozta meg. A szolgabírói hivatalnokok a szolgabíró felelössége alatt és utasításai szerint járhattak el. A fegyelmi felelősségre vonást velük szemben viszont a vegyes bizottmány gyakorolhatta.

Magyarország külön koronatartományként kezelt részein, így a téma szempontjából fontosabb Erdély, Horvátország, valamint a Szerb Vajdaság és Temesi Bánság esetében megegyezett a járási hivatal felépítése. ${ }^{268}$ Az eltérés csupán abban mutatkozott, hogy a szolgabírói elnevezést nem őrizhették meg, így a négyszintủ beosztás a következő volt: járási főnök, járási segéd, járási tollnok és járási írnok. ${ }^{269} \mathrm{~A}$ rendelet végrehajtása során a járásokban egységesen mindegyik beosztásba kineveztek legalább egy, de gyakran több hivatalnokot is, így a négyszintü beosztás megvalósult a szolgabírói hivatalokban. Minden járás élén egy-egy szolgabíró állt, a segédi pozíciót azonban legalább kettő vagy három személy töltötte be. A tollnoki tisztségre szintén két vagy három egyént neveztek ki a ráckevei járás kivételével, amelyben ilyen elnevezéssel nem talélható hivatalnok. A megyefőnök egy-egy járást legalább kettő, legfeljebb négy írnokkal láthatott el. A szolgabírói hivatalok melletti fizikai munkára pedig járásonként két-két szolgát alkalmaztak, amelyek mellé igény szerint egy-egy segítőt is rendelhettek. ${ }^{270} \mathrm{~A}$ szolgabírói hivatalban a járási ügyviteli feladatokat így a legtöbb hivatalnokot alkalmazó gyöngyösi és karcagi járásban tizenegy fó látta el.

Az 1853-ban kiadott miniszteri rendeletben az osztrák központi kormányzat a szolgabírák közigazgatási és igazságszolgáltatási hatásköreit részletesen szabályozta. ${ }^{271} \mathrm{~A}$ legfontosabb teendőik a községek működése feletti felügyelet és a közbiztonság megőrzése voltak. Emellett az újoncokról szóló listák kiállítása és a katonák elszállásolása, valamint élelmezése körüli problémák ellátása szintén egységesen a szolgabírák kötelessége volt. A neoabszolutizmus korszakában a lakosság életét felügyelő szolgabírói hatáskörök voltak a hangsúlyosak, így felügyelték a sajtót és az alapítványokat, engedélyezték a zene- és színjátékokat.

A szolgabírákkal kapcsolatban érdemes azt is figyelembe venni, hogy miképpen alakult a tisztséget betöltők javadalmazása. Ferenc József a neoabszolutizmus korszakában egy, a birodalmat összefogó egységes hivatalnokréteg megteremtésére törekedett, így

268

Cepulo 2007, 110.; 10. Verordnung der Minister des Innern, der Justiz und der Finanzen vom 19. Jänner 1853.

269

270 Commission Ofen 191/1853. A budai szervező bizottmány a Jász-Kun kerület (Distrikte Jazygien und Kumanien), Pest-Pilis, Borsod, Heves, Szolnok, Fejér (Stuhlweissenburg), Esztergom (Gran), Pest-Solt vármegye közigazgatási rendezését végezte el, így e megállapítások ezekre a közigazgatási egységekre vonatkoztathatók.

271 
céljának megfelelően az egyes hivatalnokok, így a szolgabírák központilag meghatározott fizetésében részesültek, amelyet az államkassza fedezett. Az egyes tisztségviselőket megillető fizetéseket az 1853. január 19-én megjelent miniszteri rendelet rendezte. ${ }^{272}$ Annak ellenére, hogy központilag szabták meg a szolgabírák javadalmazását, nem teljes mértékben azonos fizetésekre voltak jogosultak, mivel három eltérő összeget határozott meg a jogszabály. Magyarországon a szervező bizottságok jogköre volt a járási rendszer felállítása alkalmával arról dönteni, hogy mely járás szolgabírói keressenek 1200, 1100 vagy $1000 \mathrm{Ft}$-ot. Jellemzően a jelentősebb, megyeszékhelyhez kötődő járások szolgabírói részesültek a magasabb 1200 Ft-os javadalmazásban, bár ez nem kizárólagosan érvényesült, mivel az esztergomi járásban csupán az 1100 Ft-os kategóriába került a járási tisztviselő. Az viszont egyértelműen megfigyelheto, hogy az egyes megyékben arányosan osztották el a fizetési kategóriákat, így a lehetőségekhez mérten a megyékben mindhárom javadalmazási összeg megjelent. ${ }^{273}$

A szilveszteri pátens kibocsátását követően megkezdődött hivatalnoki életpálya kiépítése során, mivel a császár az uralkodóhoz hü állami tisztségviselőkkel kívánta betölteni a pozíciókat, ezeknek a személyeknek egy vonzó élet lehetőségét igyekezett teremteni. A szolgabírák esetében is érvényesült ugyanis az élethossziglani kinevezés, csupán a fegyelmi felelősségre vonás esetén volt lehetőség szolgálati elbocsátásra, így főszabály szerint nyugdíjazás esetén szűnhetett meg a tisztséget betöltő jogviszonya. ${ }^{274} \mathrm{~A}$ hosszú ideig állami szolgálatban dolgozó tisztségviselők, tíz évnyi állami szolgálatot követően az életük végéig nyugdíjban részesülhettek az államkassza terhére. ${ }^{275}$

\subsection{A közigazgatási szervezet visszarendeződése}

Jelentős változás volt a rendi korszakból megismert járási szervezethez képest a neoabszolutizmus korában, hogy a vármegyei önkormányzat szervéből a központi államigazgatás alsó középszintű egysége alakult ki, amely a központi államigazgatás parancsait hajtotta végre. A neoabszolutizmus korszakának nagy előnye volt, hogy modernizálta a hivatali ügyintézést a székhelyek meghatározásával. A szolgabírák és ezzel együtt a megyei tisztségviselők jogállását áttekintve arra a megállapításra juthatunk, hogy a rendi korszakból a polgári átalakulás útján a márciusi forradalomnak és az áprilisi törvényeknek köszönhetően elinduló Magyarországon a szabadságharc leverése ellenére a neoabszolutizmus időszakában a korszak szükségleteit kielégíteni képes hivatalnokréteg kialakítása vette kezdetét, amelynek a megfelelő jogszabályi hátterét is megteremtette Ferenc József tanácsosai segítségével.

\footnotetext{
272 24. A' bel-, igazság- és pénzügyi ministereknek 1853-diki január 19-kén kelt rendelete.

273 MNL OL D134 K. K. Organisierungs Commission Ofen 191/1853.

274 RÉCSI 1854, 305-307.

275 RÉCSI 1854, 363.
} 
Ferenc József 1860-ban a kedvezőtlen nemzetközi fejleményeknek és a magyarok ellenállásának köszönhetően az októberi diploma kiadásával felváltva az egységes birodalmi adminisztratív szervezetet helyreállította Magyarországon és Horvátországban az 1847 előtti vármegyei berendezkedést. ${ }^{276} \mathrm{~A}$ magyar országgyűlés viszont elutasította az októberi diplomát, aminek következményeként az uralkodó feloszlatta az ellenzéki megyei és városi bizottmányokat. ${ }^{277} \mathrm{~A}$ megyei tisztikart ennek következtében a király által pozícióba juttatott megyei vezető nevezte ki a rendi korszakkal egyező tisztviselöi állásokra. ${ }^{278}$

276 RajKay Friebeisz 1861, VI-VII.; Stipta 1995b, 71.; Cepulo 2017, 14-15.

277 Csizmadia 1976, 95.

278 DeÁK 2015, 1136-1137.; BERZEVICZY 368-369. 


\section{A MAGYAR KÖZIGAZGATÁS POLGÁRI ÁTALAKÍTÁSA}

„A kórmány és törvényhozás ugyanis midön a megye rendezéshez fogott, a legmagasabb állami érdekek egyikét, a modern állami és társadalmi élet azon biztositékát, melynek párbuzamos fejlesztése, tókélye és támogatása nélkül a jogszolgáltatás is koczkázottá válik, a jó, gyors és pontos közigazgatást akarta megszervezni. ${ }^{279}$

\subsection{A köztörvényhatóságokról szóló 1870:XLII. tc. és az elfogadásához vezető okok}

A kiegyezés létrejöttével Magyarország visszanyerte közjogi önállóságát, így az újonnan kinevezett felelös magyar kormánynak és az országgyűlésnek ismételten lehetősége nyílt az 1848-ban megszakadt magyar polgári államberendezkedés kialakításának folytatására. ${ }^{280}$ Gr. Andrássy Gyula 1867-ben miniszterelnökként elmondott programbeszédjében a magyar kormány legfontosabb feladataként jelölte meg a vármegyei rendszer újjászervezését. ${ }^{281}$ Az országgyűlés a kormány előterjesztése alapján határozatilag döntött a köztörvényhatóságok helyreállításáról, ${ }^{282}$ amely során az áprilisi törvények közigazgatásra vonatkozó rendelkezéseit vették alapul. ${ }^{283}$ Erdélyben pedig az 1848. év előtt müködő vármegyei és széki struktúrának megfelelően szabályozták a közigazgatási szervezet létrehozását. ${ }^{284}$ E rendelkezéseket a kormányzat deklaráltan csak ideiglenesnek szánta a közigazgatás törvényhozás útján való rendezéséig.

Az új magyar kormány egyik legfontosabb feladata az új polgári közigazgatást szabályozó törvény országgyưlési elfogadtatása volt. ${ }^{285} \mathrm{~A}$ kiegyezést követően azzal a problémával kellett „megküzdenie” az Andrássy-kormánynak, hogy a helyi igazgatás végrehajtására alkalmatlan a rendi korszakból „örökölt” közigazgatási szervezet. ${ }^{286} \mathrm{Az}$ államháztartási hiány és a történeti alkotmányhoz való ragaszkodás miatt azonban nem gondolhatott arra a központi hatalom, hogy új, az eddigitől független államigazgatási apparátust hozzon

\footnotetext{
MNL BM K150 117. 28287/1871. - Bars vármegye. 
létre. ${ }^{287} \mathrm{~A}$ törvényhatóságok pragmatikus átalakításával kívánták emiatt a szükséges helyi igazgatási szerveket megteremteni. ${ }^{288} \mathrm{~A}$ közigazgatás átszervezésére irányuló törekvések a vármegyék és az azok egyes szerveire nosztalgiával visszatekintő lakosság és ellenzék ellenállását váltották ki. ${ }^{289} \mathrm{Az}$ országgyűlésben a képviselők már a közigazgatás és igazságszolgáltatás elválasztására irányuló 1869:IV. tc. megalkotásakor is sérelmezték, hogy a bírák kinevezési jogosultságát a törvény elvonja a vármegyéktől. ${ }^{290} \mathrm{Az}$ országot vezető Deák-párt ennek köszönhetően felismerte, hogy a törvény körüli feszültség és a kompromisszum hiánya továbbra is terheli a magyar politikai elitet. ${ }^{291}$ Emiatt, valamint a hatalmát visszanyerő országgyűlésre háruló rengeteg feladat miatt, csak 1870-ben született meg a közigazgatási szervezet alapjául szolgáló törvény. ${ }^{292} \mathrm{~A}$ jogalkotó a vármegyék, a szabad királyi városok és a törvényben meghatározott városok szervezetét egy jogszabályban, az 1870:XLII. tc.-ben szabályozta. ${ }^{293}$ E közigazgatási egységeket egyöntetűen törvényhatóságként definiálta, így alakította ki a közigazgatás középszintjét.

Nehezítette a szervezeti átalakítást, hogy két egymással nehezen összeegyeztethetö alapelv szerint kellett a törvényt megalkotni. Egyrészről a magyar kormány bizalmatlannak mutatkozott a király szándékaival szemben, így olyan intézményeket is kívántak az újonnan létrehozott közjogi szervezetbe iktatni, amelyek biztositékul szolgálhattak az uralkodó abszolutisztikus hatalmával szemben, ha az a kiegyezés felrúgására törekedne. Ezért a vármegyék alkotmányvédő szerepének megőrzése mellett döntött a törvényalkotó. ${ }^{294}$ A modern polgári állam követelménye azonban megkívánta, hogy a felelös kormánnyal összeegyeztethető közigazgatási szervezet jöjjön létre, amely a rendi korszakból ismert jogosultságokkal nem gátolja, nem lehetetleníti el a magyar kormány müködését. ${ }^{295}$

A belügyminisztérium ezen elvek mentén alakította ki azt a közigazgatási szervezetet, amely sikeresen megfelelhetett az irányában támasztott elvárásoknak. A köztörvényhatósági törvény biztosította az aktuális kormányzat befolyását a területi közigazgatásra, hogy ezzel is megakadályozhassa a kormány és a helyi igazgatás esetleges konfliktusait. Emellett pedig az 1870:XLII. tc. megvalósította a vármegyék és a szabad királyi városok hozzáigazítását az 1848:III. tc.-kel bevezetett miniszteri felelősség elvéhez. ${ }^{296}$ Minden olyan feladatkört igyekeztek a vármegyék kezében meghagyni, amelyek a modern közjogi elképzelésekkel összeegyeztethetők voltak.

A dualizmus rendszeréből fakadt az a megoldás, hogy az 1870:XLII. tc. a törvényhatóságok költségvetését, ingatlannal kapcsolatos adásvételi szerződéseit, kölcsönfelvételeit

\footnotetext{
287 STIPTA 1985, 910.; STIPTA 1998b, 89-91.

288 KI 1869. V. k. 188.; Stipta 1998b, 87.; STipta 2005a, 220.; PAPp 2012, 100-101.

289 Erre például szolgál a 48-as Párt nevében benyújtott határozati javaslat (KN 1869. IX. k. 19-20.; KI 1869. VI. k. 195-196.); VARGA 2007a, 467.

290 MÁTHÉ 1982, 37-39.

291 VARGA 2009, 230-231.

292 SARLÓs 1976, 13-16.

293 MÁtHé 2015, 154.

294 SARLós 1976, 14-15.

295 VARga 2009, 229; SzÉKELY 2018, 166.

296 VARGa 2007b; VARga 2009, 227.; STIPTA 1998b, 82.; Szabó 2017, 417.; Ruszoly 2009, 93.; SzaBó 2008, 132-133.; BARANy 1975, 421.; Szente 2011, 289-291.; PAPP 2012b, 63.
} 
és hivatalok létrehozását vagy megszüntetését a kormány jóváhagyásához kötötte. A centralizáció e formája azért volt szükséges, mert e kérdésekben a kormányzat döntése is uralkodói jóváhagyásra szorult az előszentesítési jog következtében. A kormány pedig nem biztosíthatott több jogot a törvényhatóságoknak, mint amivel maga is rendelkezett. ${ }^{297}$

A köztörvényhatóságokról szóló törvény feljogosította a vármegyéket és a törvényhatósági jogú városokat az önkormányzati jogok és az állami közigazgatás közvetítésére. A törvényhatóságok jogosultak voltak sajátos jogszabályt, szabályrendeletet alkotni, amellyel saját területükre kiterjedő, magasabb szintű jogszabállyal nem ellenkező módon szabályozhatták az általuk meghatározott kérdéseket. ${ }^{298}$ Kővár vidék végrehajtási munkálataiból kirajzolódott, hogy mely közigazgatási hatásköröket tartott a legfontosabbnak a törvényhatóság:

\section{„A törvényhatóság köteles \\ 1. saját közegei által a törvényeket és törvényen alapuló kor- mányrendeleteket közigazgatási szempontból végrehajtani, \\ 2. saját hatáskörében mint azállam kormányzat egyik kiegé- szitö része közvetitendi az állam közigazgatást, \\ 3. gyakorolandja az árva és gyámhatóságot, \\ 4. a közrendörséget illetóleg a személy és vagyon biztonság felïgyeletét is a vidék köteles kezeltetni saját közegei által."299}

Kővár vidék összefoglalójából is kitűnik, hogy a közigazgatás rendezésének következtében a középszintű közigazgatási egységek ellátták az államigazgatási feladatokat is az önkormányzati jogaik gyakorlása mellett, mivel önálló, elkülönült államigazgatási szervezetrendszert nem hoztak létre Magyarországon. Az Osztrák-Magyar Monarchia társországában, az Osztrák Császárságban ezzel szemben elvált egymástól a két szervezetrendszer, így a közigazgatás középszintje „megkettőződött”."300

A törvényalkotó a vármegyei hatáskörök részleges megtartása mellett a rendi hagyományok megőrzése céljából a neoabszolutizmus során az osztrák kormányzat által is alkalmazott mintát követte, ami azt jelentette, hogy az eredeti tisztségviselő elnevezéseket igyekezett megőrizni, azokat azonban eltérő tartalommal töltötte meg, így teremtve meg a régi szervezeti keretek között a modern jogelvek átültetését. ${ }^{301} \mathrm{~A}$ jogalkotó a legfontosabb tisztviselők szerepét, hatáskörét az eredeti elnevezéseket megőrizve szabta meg. A kisebb jelentőséggel bíró tisztviselők feladatmegosztását, alkalmazását a vármegyék hatáskörében hagyta, megőrizve nekik azt a jogosultságot, hogy az egyes tisztviselök hagyományos neveiket ebben az estben is megtarthatták. ${ }^{302}$

\footnotetext{
297 SARLós 1976, 39.

298 KAJTÁr 2004, 28.

299 MNL BM K150 118. 22499/1871.

300 Reiter-Zatloukal 2014, 217.; Brauneder 1992, 51-52.; Hellbling 1975, 214-218.; Lehner $1992,220-221$.

301 STIPTA 1992b, 481.

302 SARLÓs 1976, 91.
} 
A törvényhozó munkáját problémássá tette az is, hogy a rendi kori közigazgatási szervezet helyreállításának köszönhetően az ország adminisztratív területi beosztása évezredes történelmi fejlődés eredményeképpen alakult ki, így az egyes közigazgatási egységeket a hagyomány és nem a tervszerü területszervezés hozta létre. ${ }^{303}$

Ereky István a kiegyezéskori Magyarországot négy történelmi alapokon kiépült, különböző elvek szerint kialakított területrészre osztotta. (1) A vármegyei rész $275323 \mathrm{~km}^{2}$-en terült el és mintegy 11 millió 800 ezer lakossal bírt. (2) A szabad kerületi és királyföldi területek a vármegyei igazgatás alól kiemelt országrészek voltak, amelyek összesen 693 ezer lakossal és $15302 \mathrm{~km}^{2}$-nyi területtel rendelkeztek. Ereky a következő területeket sorolta a szabad kerületek közé: a turpolyai nemesi, a jászkun, a hajdú és a fiumei kerületet, a szepesi XVI várost, a nagykikindai kamarai és a tiszai koronai kerületeket. (3) A korlátlan katonai igazgatásnak alávetett terület szintén nem tartozott vármegyei igazgatás alá, amelynek lakosságszáma 1 millió 38 ezer, területe pedig $34225 \mathrm{~km}^{2}$ volt. ${ }^{304}$ (4) Emellett pedig 67 önálló városi törvényhatóságot különböztettek meg, amelyek szintén különálló közigazgatási területtel rendelkeztek. ${ }^{305}$

Az azonos elnevezésủ területi beosztás alá tartozó területi önkormányzatok szervezeti felépítése sem egyezett meg egymással. A magyar Szent Korona országai Dalmácia nélkül 49 magyarországi vármegyére, nyolc erdélyi magyar vármegyére, hét horvát-szlavón vármegyére, öt székely és kilenc szász székre, öt magyarországi (nagykikindai, hajdú, jászkun, szepesi XVI, tiszai koronai) és két horvátországi kerületre (turpolyai, fiumei), egy magyarországi, két székely és két szász (brassói, besztercei) vidékre, valamint a városi törvényhatóságokra és a katonai határőrvidékre oszlottak. A szász törvényhatóságok emellett még egy magasabb rangú törvényhatóságot alkottak Királyföld néven.

Ebből látható, hogy Horvátország a kiegyezést követően újra a Magyar Királyság fennhatósága alá került, ám a horvát-magyar kiegyezés következtében a horvát belügyi igazgatás függetlenné vált. ${ }^{306} \mathrm{~A}$ Határőrvidék státuszának rendezésére szintén szükség volt, mivel a horvát és magyar területek között elhelyezkedő országrész a 18. század eleje óta a bécsi katonai kormányzat irányítása alatt állt. A Határőrvidéket így 1867 és 1873 között demilitarizálták, ${ }^{307}$ majd ezt követően 1882-ben Horvátországhoz csatolták. ${ }^{308}$ Erdély viszont ismételten a Magyar Királyság részévé vált, ${ }^{309}$ így e területen is a magyarral azonos adminisztrációt kellett teremteni. ${ }^{310} \mathrm{~A}$ magyar kormányzat által irányított terület így 57 megyére, öt kerületre, öt vidékre, 14 székre és 67 városi törvényhatóságra volt felosztva, így az állam területe 148 önálló önkormányzatisággal rendelkező területre tagolódott. ${ }^{311}$

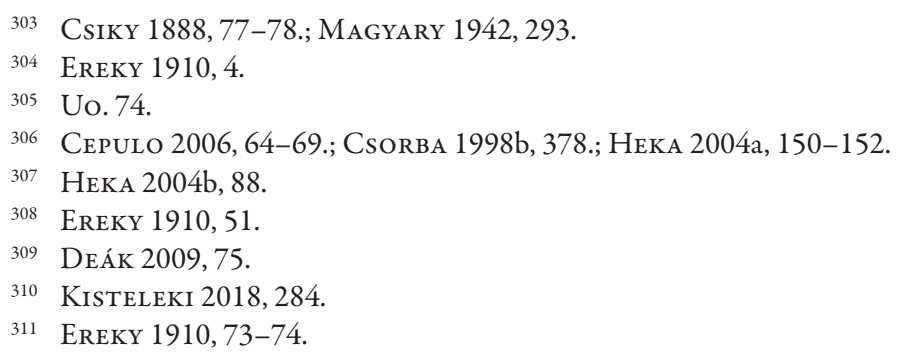

Csiky 1888, 77-78.; MAgYary 1942, 293.

EREKY 1910, 4.

Uo. 74.

Cepulo 2006, 64-69.; Csorba 1998b, 378.; Heka 2004a, 150-152.

HeKa 2004b, 88.

EREKY 1910, 51.

DEÁK 2009, 75.

KISTELEKI 2018, 284.

EREKy 1910, 73-74. 
Az aránytalanul nagyszámú közigazgatási egységnél is súlyosabb problémát jelentett ezek szabálytalan formája és szétszabdalt területe. A legsúlyosabb problémát az enklávék jelentették. A Jász-Kun kerület három különálló részből állt, amelyek közül az egyik a kerület székhelyétől, Jászberénytől 173 km-re került. A Heves vármegyéhez tartozó Dévaványa pedig Békés vármegye és a Nagykunság között olyan nagyfokú függetlenséget élvezett a vármegye központjától elszakadva, hogy külön „köztársaságnak” tartotta magát. Erdélyben Felső-Fehér vármegyét egymástól távol fekvő 18 rész alkotta. A széttagoltság miatt a központ irányítása nehezen érvényesült, a képviselöik nem vettek részt hatékonyan a vármegye munkájában. ${ }^{312} \mathrm{~A}$ legsúlyosabb problémákat majd csak az 1876:XXXIII. tc. rendezte: az enklávékat megszüntette és a kerületek, a székek és a vidékek különállását eltörölte. ${ }^{313}$

A magyar kormányzatnak ezekből a partikuláris, eltérő önkormányzati igazgatási szervezetekkel rendelkező területi önkormányzatokból kellett a polgári közigazgatás igényeit kielégítő, modern szervezetet kialakítani, mivel ragaszkodtak a történelmileg kialakult adminisztratív egységek területi integritásához. Ezt az alapelvet már az 1847-1848. évi országgyülés követei megfogalmazták az 1848:V. tc. 4. §-ában, miszerint az országos választókerületekre való felosztás nem befolyásolja a vármegyék, a kiváltságos kerületek és a szabad királyi városok önállóságát és területét. A vármegyék nagyfokú átszervezését emellett gátolta, hogy a magyarság Magyarország területén kisebbségen volt a kiegyezés időszakában a nemzetiségekkel szemben. A vezető elit ugyan a nem magyar anyanyelvü lakosság számára nyelvhasználati jogot és egyenjogúságot kívánt biztosítani, ${ }^{314}$ de a magyarság politikaformáló szerepének megkérdőjeleződését és így a kiegyezés rendszerének veszélyeztetését el akarták kerülni. E szempontok is a vármegyék határainak újraszabása ellen szóltak, mivel félő volt, hogy ezáltal a nemzetiségek bizonyos vármegyékben túlsúlyba kerülnének, és így hatékonyabban léphetnének fel az ország ügyeinek alakításában. ${ }^{315}$

\subsection{Centralizáció-decentralizáció a dualizmus rendszerében}

A centralizáció és a decentralizáció egymással szorosan összefüggő fogalmak, az egyes korszakokat a két államszervezési elv „eltérő dominanciája jellemezte.” ${ }^{16}$ Nagy Ernő értelmezésében a kormányzás centralizálása alatt azt értjük, ha a központi kormányzat minden döntési jogkört magának vindikál. Véleménye szerint így már decentralizációról beszélhetünk, ha önkormányzattal rendelkező testületek részt vesznek az igazgatásban és a döntésekben. ${ }^{317} \mathrm{~A}$ közigazgatási jogi téma okán az adminisztratív centralizáció jelentkezését érdemes vizsgálni az 1870:XLII. tc. kapcsán. Magyary adminisztratív centralizáció

\footnotetext{
312 EREKy 1910, 76-79.

313 Stipta 1976, 111-150.; Hajdú 1993, 61.; Nyakas 1980, 5-17.

314 Csernus-LukÁcs 2017, 189-191.; Csernus-LukÁcs 2016, 363-366.

315 EREKy 1910, 103-105.

316 SiKeT 2020, 26.

317 Nagy 1899, 513.
} 
alatt az értette, hogy az állami föhatalom, a kormány olyan hatásköröket szerez, amelyek által képessé válik az alárendeltektől kikényszeríteni, hogy a törvényekkel összhangban müködjenek. ${ }^{318} \mathrm{Ha}$ ebből a fogalomból indulunk ki, akkor az 1848:III. tc. megalkotása és ezáltal a felelős magyar Ministerium létrejötte magában hordozta az adminisztratív centralizációt. Ennek beteljesedését pedig az jelentette, hogy a vis inertiae jogát az 1870:XLII. tc. kiiktatta a magyar közigazgatási szervezetből. Ez a jogosultság ugyanis továbbra is biztosíthatta volna a vármegyék számára, hogy hatékonyan ellenálljanak a kedvezőtlen kormányzati rendelkezések végrehajtásának. Ennek kapcsán azonban érdemes megjegyezni, hogy a kiegyezés időszakában született művében Kecskeméthy Aurél felhívta arra a figyelmet, hogy az önkormányzati jogok törvényekkel szembeni gyakorlása a magyar történeti alkotmányba ütközik, ${ }^{319}$ szóval, ha az adminisztratív centralizáción csupán a törvények betartatását értjük, akkor ezt nem lehet összefüggésbe hozni a paszszív ellenállással. A vis inertiae helyébe a felirati jog lépett, amely korlátozottabb módon biztosította a kormányrendeletekkel szembeni fellépés lehetőségét, ugyanis a végrehajtás végleges megakadályozására nem adott módot.

A kormányzatnak a dualizmus védelme érdekében mindenképpen a centralizmus megerősítésére is törekednie kellett, amely tovább erősítette ezt a hatást. Ennek elérése céljából a köztörvényhatóságokról szóló törvényben a belügyminiszter javaslatára fenntartották a király által kinevezett, így a kormányhoz kötődő főispáni méltóságot és bevezették a virilizmust. ${ }^{320} \mathrm{~A}$ közigazgatási centralizációnak számos értelmezése lehetséges, ${ }^{321}$ amely miatt komoly viták alakultak ki a törvény megalkotása során az országgyülésben. ${ }^{322} \mathrm{Az}$ ellenzék álláspontja szerint a centralizáció a nép kiszorítását jelentette a hatalom gyakorlásából, ami az önkormányzatiság megszűnéséhez vezet. A kormánypárti képviselők viszont inkább csak olyan célkitűzést láttak ebben, ami biztosítja a közigazgatási szervek egységes elv alapján való felépítését és a központi kormányszerv felügyeleti jogát az intézkedő hatóság felett. E felügyeleti jog gyakorlására volt igazán alkalmas eszköz a fóispáni tisztség. A virilisták által pedig egy, a kormányzattal szimpatizáló többséget kívántak biztosítani a vármegyék meghatározó testületi szervében. A föispán képviselte tehát középszinten a végrehajtó hatalmat és ellenőrizte a törvényhatóságok működését. A közigazgatási feladatokat a törvényhatóságban pedig a választott tisztviselők látták el az alispán vezetésével. ${ }^{323}$

Ezen elemek ellenére azonban nem beszélhetünk döntően centralizált közigazgatásról, ugyanis a törvény értelmében a törvényhatóságok megtarthatták önkormányzati hatásköreik jelentős részét. A virilizmus okán viszont meg kell jegyezni, hogy ezeket a jogosultságukat a kormányzat igyekezett a neki kedvező döntéseket hozó önkormányzati testületnek biztosítani. Csupán a törvényhatósági bizottság jogköreit vizsgálva a törvény alapján inkább decentralizált közigazgatásról beszélhetünk, mivel a közigazgatás befo-

\footnotetext{
318 Magyary 1942, 104-105.

319 KeCSKemÉthy $1867,38-39$.

320 VARga 2013, 725.; VARga 2011, 43-46.

321 KMETy 1905, XXX.

322 Csorba 2000, 194.

323 MÁTHÉ 2017, 432.; VÖRÖS 1956, 13.
} 
lyásolására hagyott meg számukra eszközöket a jogalkotó, ha a tisztviselők határozott idejü mandátummal való megválaszthatóságát, vagy a pénzügyi, költségvetési önállóságot figyelembe vesszük. A dualizmus közjogi rendszere miatt a középszintű közigazgatási egységeknek a decentralizáció érvényesítésekor is csupán olyan jogköröket biztosíthatott az országgyűlés, amelyekkel a kormányzat is rendelkezett. Azt azonban meg kell jegyezni, hogy a törvényben biztosított kormányzati jogkörök erőteljes alkalmazása nagymértékben fokozhatta a centralizáció mértékét.

\subsection{A közigazgatás modernizálásának követelményei a 19. században}

A köztörvényhatóságok rendezéséről szóló törvénycikk alapján létrejövő járási szervezet elemzéséhez érdemes azokat az elveket áttekinteni, amelyek érvényesítését a korszak gondolkodói a modern közigazgatási szervezet feltételének tekintették. A törvény indokolása nem ismertette az elkészítése során követett alaptételeket, de a közigazgatás és az igazságszolgáltatás szabályozásánál érezhetően vezérfonalul szolgáltak ezen elméleti megoldások. Az indokolás csupán azt tűzte ki célul, hogy gyors és pontos közigazgatás jöjjön létre olyan módon, hogy a miniszteri felelősséggel a törvényhatóságok szervezetei összhangba kerüljenek. ${ }^{324}$

Récsi Emil A közigazgatási törvénytudomány kézikönyve címü 1854-ben megjelent művében a neoabszolutizmus államszervezetének bemutatása kapcsán vázolta azokat az alapelveket, amelyek meghatározták annak felépítését és ennek során kifejtette azokról vallott nézeteit. Ennek köszönhetően képet kaphatunk arról, hogy a korszak kiemelkedő - igaz, sokat bírált - közigazgatási szakírója mely szempontokat tartotta a 19. századi modern adminisztráció legfontosabb követelményeinek. ${ }^{325} \mathrm{~A}$ járási szint vizsgálatánál felhasználható öt kritérium közül első helyen a központosítás és egyformaság fontosságát emelte ki. A központosítás alatt azt értette, hogy minden igazgatási tevékenységnek a központi hatóságokra visszavezethetőnek kell lennie. Az egyformaság elve pedig megkövetelte, hogy az ország minden részében azonos módon épüljenek fel a hatóságok. ${ }^{326} \mathrm{Ez}$ a törekvés nyilvánvalóan észrevehető az 1870:XLII. tc. rendelkezéseiben, mivel az összes területi önkormányzatot egységesen köztörvényhatósággá alakították a Királyföld kivételével, így a kiváltságos kerületek megtarthatták ugyan elnevezéseiket, de közigazgatási szervezetüket a vármegyékhez hasonlóan kellett megszervezniük. Ennek megfelelően a székelyek főkirálybírája, a szász városok grófja, valamint a kerületek és vidékek főkapitányai címeiket megőrizték, de a főispánnak megfelelő hatáskörrel rendelkeztek. A járások kialakítása esetén ugyanígy hiányoztak az egységes szervezeti megoldások, így igyekeztek ezeket az új törvényben megteremteni. Ez a törvény végrehajtása során érzékelhetően a belügyminisztérium munkáját is áthatotta, amely célkitűzés a Hont vármegyének küldött

\footnotetext{
324 KI 1869. V. k. 188-189.

325 KoI 2013, 69.

326 RÉCSI 1854, 20-22.
} 
válaszleiratában szövegszerüen is megjelent: „észrevételemet annyiban inkább fentartom, és érvényesiteni kivánom, mert az e részben tett hasonló figyelmeztetésemet az ország többi törvényhatóságai elfogadván, már csak egyöntetüség szempontjából is szükséges, hogy az átalános megállapodáshoz Hont megye közönsége is alkalmazkodjék."327

Récsi hangsúlyozta a testületi és az egyszemélyi döntéshozatal közötti egyensúly megteremtésének jelentőségét is. Az alsóbb hivatalokban az egyszemélyi vezetés és a felelösségre vonhatóság biztosítását tartotta a modern közigazgatás nélkülözhetetlen elemének. Véleménye szerint az államszervezet ötödik fejlesztendő eleme a közigazgatás és az igazságszolgáltatás elválasztása. E kérdést két szempontból tartotta vizsgálhatónak: elsődlegesen a két hatalmi ághoz tartozó ügyek egymástól független elbírálását vélte kívánatosnak, a szervezeti elkülönítésüket ehhez képest másodrangú követelményként jelenítette meg. ${ }^{328} \mathrm{~A}$ járási szervezet kiépítése során eme alapelvek áthatották az országgyưlés és a belügyminisztérium munkáját is, ahogy erre az egyes szervezeti megoldások kapcsán rá is mutatok a következő fejezetekben.

\subsection{A közigazgatás és az igazságszolgáltatás elválasztása}

A neoabszolutizmus korszakának lezárultával ismételten napirendre került, hogy szükséges lenne a modern államszervezet ezen alapelvét konzekvensen, minden szinten megvalósítani. Csemegi már 1862-ben született tanulmányában hangsúlyozta a két hatalmi ág személyi elkülönítésének fontosságát, amely biztosította volna a kellő szakértelem megszerzésének lehetőségét a hivatal betöltői számára. Emellett azonban annak jelentőségét is kiemelte, hogy a bíróságok számára lehetővé kell tenni, hogy a közigazgatás működését ellenőrizhessék. ${ }^{329}$ Trávnik Antal 1868-ban megjelent írásában a Jogtudományi Közlöny hasábjain szintén kiemelte a két hatalmi ág elkülönítésének szükségességét, mivel ő is úgy vélte, hogy ezáltal lesz elérhető, hogy a bírák teljes munkaidejüket az ítélkezésre fordíthassák, amely tudományos felkészültségükre is pozitív hatással lesz. ${ }^{330}$

A politikai aktorok számára sem volt kétséges, hogy a két hatalmi ág elválasztását meg kell valósítani a magyar államszervezet reformja során. A kormánypárt egyértelmű célja volt a törvénykezés elkülönítése a közigazgatástól. A Szegeden létrejött, kormánypárti Szabadelvű Kör is kifejezte az elv véghezvitelének nélkülözhetetlen voltát. ${ }^{331}$ Az ellenzék vezére, Tisza Kálmán sem vitatta a jelentős ügyekben az önálló bírósági szervezet megteremtésének fontosságát, azonban nem értett egyet azzal, hogy ezt a vármegyei tisztviselők bíráskodási jogköreiktől való teljes megfosztásával kellene megvalósítani. ${ }^{332}$ A közvéleményt leginkább megosztó vita akörül alakult ki, hogy bírák miképpen nyer-

\footnotetext{
MNL BM K150 118.31986/1871.

28 RÉCSI 1854, 22-27.

329 Csemegi 1904, 96-98.

330 TRÁvNiK 1868, 21.

331 Ruszoly 1982, 51.

332 Tisza 1865, 32-33.
} 
jék el tisztségüket. A kormánypártiak a kinevezési elvet preferálták, amely a központi kormányzat jogosultsága lett volna. ${ }^{333} \mathrm{Az}$ ellenzékiek viszont a választás elvét kívánták meghonosítani a bírák esetében is, viszont köztük is megoszlottak a vélemények annak kapcsán, hogy ki gyakorolhatja a választási jogosultságot. ${ }^{334} \mathrm{~A}$ törésvonalak azonban egyértelmüen nem húzhatóak meg e kérdésben azáltal, hogy a kormánypárti vagy az ellenzéki gondolkodók azonos módon vélekedtek volna egyes kérdésekben, ugyanis a Deák-párti Szentkirályi Móric a vármegyei szervezetrendszerhez igazította volna továbbra is az igazságszolgáltatást, ${ }^{335}$ sőt a választási elv megőrzése mellett kardoskodott. ${ }^{336}$

A közigazgatás és az igazságszolgáltatás elválasztását végül az országgyủlés a bírói hatalom gyakorlásáról szóló 1869:IV. tc.-ben mondta ki. ${ }^{337}$ A törvény megalkotásában kulcsszerepet vállalt Horvát Boldizsár az Andrássy-kormány igazságügyminisztere, ${ }^{338}$ aki a modern állam megteremtésének egyik fontos követelményének tartotta a két hatalmi ág elválasztását. Igazságügyi államtitkárként Csemegi Károly volt az 1869:IV. tc. megfogalmazója. ${ }^{39}$ A jogszabály értelmében a bírák királyi kinevezéssel nyerték el tisztségüket az igazságügyminiszter ellenjegyzése mellett, így a vármegyék véglegesen elvesztették hatáskörüket a bírák megválasztására. A két hatalmi ág elválasztása kapcsán azonban ezen kívül a törvény szűkszavúan csupán az alapelvet rögzítette, annak gyakorlati megvalósítáról nem rendelkezett a jogalkotó. Az alapelv helyi szintű átültetéséről így az országgyűlésnek kellett a későbbiekben rendelkezni, amely kötelezettségének a köztörvényhatóságokról szóló 1870:XLII. tc.-kel és az az első folyamodású bíróságok rendezéséről szóló 1871:XXXI. tc.-kel tett eleget, amelyek különálló törvénykezési és közigazgatási szervezetet építettek ki az egész ország területén. ${ }^{340}$

\subsection{A közigazgatási szervezet törvényhatóságok általi kiépítése}

Az 1870:XLII. tc.-et úgy alkotta meg a törvényhozó, hogy a korábbiakban a magyar közigazgatásra jellemző nagyfokú autonómiát a vármegyék megőrizhessék. ${ }^{341}$ Emiatt a törvényszöveg tartózkodott a részletes szabályozástól, és inkább csak a kiépítendő szervezet kereteit kívánta megszabni, ${ }^{342}$ amelyek korlátai között a törvényhatóságok létrehozhatták

\footnotetext{
333 KeCSKemÉthy 1867, 69-70; Ruszoly 1982, 51.

334 Magyar UjSÁg RÖPIRATA 1868, VI-24-VI-25.; TisZa 1865, 33.

335 SZENTKIRÁlYi $1867,72-77$.

336 Uo. 46-48.

337 Koncz 2018, 78.; SARlós 1976, 23.; DEgré 1996, 215.

338 Csizmadia 1976, 105.

339 EDVI 1904, VIII.; XVI.

340 Megyeri-PÁlfFi 2018, 59.

341 KI 1869. V. k. 189-485. Indokolás a köztörvényhatóságok, és a községek rendezéséről szóló törvényjavaslatokhoz.

342 Csanád vármegye a következőképpen fogalmazta meg az általuk készített tervezet bevezetőjében: „Maga a törvény, melynek alkotóit szintén e czél lelkesiti, már határozott kör vonalakat szabott elénk" - MNL BM K150 117. 17803/1871.
} 
saját közigazgatási szervezetüket. ${ }^{343}$ Ennek oka, hogy a rendi korszak széleskörü vármegyei hatásköreit leginkább a közigazgatás helyi szintü megvalósításában vélték fenntarthatónak.

A már bemutatott egységesség igényét a magyar kormányzat sem hagyhatta figyelmen kívül, így a centrális intézkedések is szükségessé váltak a közigazgatási szervezet helyi szintű kialakításánál. A kiegyezést követő közigazgatási reformok legfőbb célja az volt, hogy az ország államigazgatásának irányítását a felelős magyar kormány végezze. A területi önkormányzatok közigazgatási szervezete pedig nem csupán a helyi önkormányzati feladatokat látta el, hanem az állami közigazgatás közvetítését is elvégezte. ${ }^{344} \mathrm{Az}$ állami közigazgatás közvetítése alatt azokat az ügyeket értették, amelyeket nemcsak általános jelleggel szabályozott az országgyülés vagy a kormány, hanem jelentőségük miatt határozati úton részletekbe menően is rendeztek. ${ }^{345}$ Emiatt nem engedhette meg a kormányzat azt, hogy tőle teljesen függetlenül alakítsák ki a törvényhatóságok szervezetüket, mivel a miniszterek tevékenységükért csak úgy vállalhattak felelősséget, ha tudták, hogy intézkedéseiket helyi szinten mely szervek fogják végrehajtani.

Emellett a már bemutatott vármegyei függetlenségnek és az ebből fakadó partikuláris szervezetnek az előnyein kívül a kiegyezés korára már a hátrányait is felismerték, hiányoztak ugyanis a kormányzásához szükséges, az ország minden részében azonos hatóságok. Ez a probléma különösen szembetűnővé vált azáltal, hogy a neoabszolutizmus időszakában viszont megvalósult az egységes közigazgatási szervezet. Ennek következtében a jogalkotónak a központosítást és az egyformaságra törekvést egyensúlyba kellett hozni a törvényhatóságok önkormányzati jogainak biztosításával, amelynek célja a közigazgatási feladatok egységes ellátása az azonos szerkezetű és szervezetű törvényhatóságokkal. ${ }^{346}$

Ezen okokból az 1870:XLII. tc. úgy szabályozta a területi önkormányzatok igazgatási szervezetének kialakítását, hogy az a köztörvényhatóságok hatáskörébe került a minisztérium ellenőrzése mellett. A fentebb sorolt indokok mellett az a körülmény is ezt a megoldást támogatta, hogy a köztörvényhatóságok jelentősen eltérő területtel és lakosságszámmal rendelkeztek, így a központi kormányzat egységes, minden területi önkormányzat esetében azonos közigazgatási szervezetet nem tudott volna kialakítani. Emiatt is tanácsos volt a helyi viszonyokat ismerö helyi politikai szervekre bízni a közigazgatási szervezet kialakítását.

A köztörvényhatóságok számára a törvény megszabta a középfokú közigazgatási szervezet lényeges kereteit, amelyek alapjául szolgáltak a törvényhatóság szervezési munkájának. E törvény rendelkezett az alsó középszintű közigazgatás kiépítéséről is. Az 1869:IV. tc. rendelkezései alapján ugyanis a járási szinttől elvonták az igazságszolgáltatási teendők

„A kormány biztositva látván az állami közigazgatás érdekeit, a törvényjavaslatban felvett intézkedések által nem látta szükségét annak, hogy a megyék, székek, kerületek, vidékek, különösen pedig a szabad királyi városok szervezetét szabatosan meghatározza, hanem annak megállapitását a törvény korlátai között magokra bizza a törvényhatóságokra." - KI 1869. V. k. 198.

344 STIPTA 1998b, 83.; "[Á]thatva az alakulás e nagy müvének fontosságától javaslatunkban a jó, pontos és aránylag olcsó helyi közigazgatás feltételei mellett, egyszersmind az állami igazgatás érdekeit is szem elött tartottuk." - MNL BM K150 117. 17808/1871. - Fejér vármegye.

346 Hencz 1973, 108.; Stipta 1992b, 482. 
ellátását, ${ }^{347}$ így a jogalkotó feladata az volt, hogy a közigazgatási feladatok elvégzésére alkalmas egységeket hozzon létre. A közigazgatás alsó középszintjéről azonban csupán egyetlen szakasz erejéig rendelkezett a törvény, amelyben rögzítették a szolgabíró feladatait és a közigazgatási szervezetben elfoglalt helyét, de a hivatali felépítésről és a járások területi beosztásának kérdéséről már a vármegyék dönthettek. Az 1870:XLII. tc. 62. \$-a a törvény által nem szabályozott tisztviselők feladatkörének, a segéd-, kezelö- és szolgaszemélyzet létszámának és hatáskörének meghatározását szintén a törvényhatóságokra bízta.

A meghatározott feladatokat a vegyes és átmeneti rendelkezések között található 91. \$ konkretizálta, amely kötelezte a törvényhatóságokat, hogy a belügyminiszter által kitűzött határidő alatt közgyűlést tartsanak. A közgyüléseken a föispánok vagy a polgármesterek elnökletével működő küldöttségeket kellett létrehozni, amelyeknek öt, az átalakuláshoz kapcsolódó tervezetet kellett kidolgozniuk: (1) a törvényhatóságok szolgabírói járásokra osztásáról az országos választókerületek (országgyűlési) figyelembevételével;(2) a törvényhatósági bizottságok tagjainak megválasztásához szükséges törvényhatósági választókerületek kialakításáról;(3) a tisztikar, segéd-, kezelő- és szolgaszemélyzet létszámának, fizetésének, napi dijának, hatáskörének meghatározásáról;(4) a törvényhatósági joggal bíró városoknak a közigazgatási szervezetük kialakításáról;(5) az árvaszékek létrehozásáról és az árvaügyeknek a törvénykezéstől való átvételéről, valamint a törvényhatósági bizottság ügyeit előkészítő állandó választmány megalakításáról.

Emellett a létrehozandó küldöttségnek kellett gondoskodnia a törvényhatósági bizottságok megalakításáról, amelyhez szükséges volt összeállítani a választókerületek választóinak névjegyzékét, elkészíteni a legtöbb adót fizetők névsorát, valamint a községek útján intézkedni a községi alválasztókerületek létrehozásáról.

A törvényhatósági jogú városok és a vármegyei törvényhatóságok eltérő közigazgatási szervezettel rendelkeztek, így azok küldöttségeinek a saját közigazgatási szervezetükhöz illeszkedő tervezeteket kellett alkotniuk. ${ }^{348} \mathrm{~A}$ városi törvényhatóságok így a járási szervezettel kapcsolatos tervezetek elkészítését mellőzhették. Ezekről az operátumokról a közgyűlés határozott, majd a küldöttség és a közgyűlés közös munkájából létrejött javaslatokat megerősítés céljából felterjesztették a belügyminiszternek. ${ }^{349} \mathrm{~A}$ kormányzat a belügyminisztériumi megerősítéssel kívánta biztosítani az egységes és a törvény rendelkezéseinek megfelelő közigazgatási szervezet létrejöttét. ${ }^{350}$

A kiegyezést követően létrejött közigazgatási szervezetet tehát a középszintű önkormányzatok törvényértelmezése alakította ki, amelyet a belügyminisztérium koordinált. A kormányzat ezzel a rendszerrel kívánta megoldani az ország helyi igazgatását végző egységes szervezet kialakítását, ugyanis a minisztérium számára való felterjesztéssel ellenőrizhették a törvény végrehajtását és az esetleges eltéréseket javithatták. ${ }^{351} \mathrm{~A}$ küldöttségi munkálatokat a föispán irányította, akit a belügyminiszter javaslatára a király nevezett

\footnotetext{
347 MÁthé 1982, 39-40.

348 VARGa 2010b, 119-120.; VARga 2002, 60.; VARGA 2018, 443-464.; Ruszoly 1982, 55-61.; Antal 2011, 192-193.

349 Stipta 1992b, 482-483.

350 PAPP 2012, 99.; VARGa 2007b.

351 SARLÓs 1976, 77.
} 
ki a törvényhatóság élére. ${ }^{352} \mathrm{~A}$ föispán egyrészt a tervezetek elkészítése során érvényesíthette a kormányzat érdekeit, másrészt pedig szakmai hozzáértése biztosíthatta, hogy az utólagos megerősítés csak kisebb átalakításokat tegyen szükségessé a tervezeteken.

\subsection{Az 1870:XLII. tc. végrehajtása}

A törvényben meghatározott feladatok végrehajtásának megkezdésére azonban csupán egy évvel később került sor. A belügyminiszter 1871. május 15-én adta ki a 12183. számú leiratát, amelyben utasította a köztörvényhatóságok főispánjait, főkapitányait, főkirálybíráit és kerületi grófját (a továbbiakban egységesen fơispán), hogy június 15-ére hívják össze vármegyéjük közgyưlését a közigazgatás újjászervezéséről szóló tervezetek elkészítését végző küldöttségek megalakítása céljából. A belügyminisztériumi leirattervezetben még június 14-e szerepelt, ám furcsa módon a törvényhatóságoknak megküldött leiratban már június 15-ét tüntették fel a közgyülés összehívásának időpontjaként.. ${ }^{353} \mathrm{~A}$ szokásoktól eltérő megoldás volt, hogy a belügyminiszter határozza meg a közgyülés összehívásának napját, emiatt kijelentette leiratában, hogy erre a köztörvényhatósági törvény hatalmazza fel a küldöttségi munkálatokról döntő közgyűlés esetében. ${ }^{354} \mathrm{~A}$ belügyekért felelős kormánytag magyarázata azonban csak részben helytálló. A törvény csupán a határidő kitűzésére adott számára jogosultságot nem pedig a közgyűlés pontos napjának meghatározására. ${ }^{355}$

A föispánoknak írott első leirattervezet még tartalmazott utalást arra nézve, hogy a törvényhozás az 1848:XVI. tc. céljainak megfelelően alkotta meg a törvényhatóságok rendezéséről szóló törvényt, amelyet a tervezet ellenőrzésekor kihúztak a szövegezésből. ${ }^{356}$ Ennek oka az lehetett, hogy az 1870:XLII. tc. megalkotásakor a Képviselőházban az ellenzéki képviselők leginkább azt vitatták, hogy az áprilisi törvények által tervezett közigazgatási elveknek megfelelve született meg a polgári közigazgatást létrehozó törvény. Ennek oka az volt, hogy a vármegyék elveszítették az új polgári államszervezetben törvényhozással kapcsolatos (követküldés) és igazságszolgáltatási hatásköreiket, ${ }^{357}$ amely változásnak ellenzői azzal érveltek, hogy ez ellentmond az 1848:III. tc. azon rendelkezéseinek, amely szerint: „Az ország minden törvényhatóságainak eddigi törvényes hatósága ezentúl is teljes épségében fentartandó."358

A belügyminisztérium a főispánoknak és a törvényhatóságoknak külön-külön leiratot küldött. A belügyminiszteri leirat nem tartalmazott részletes utasítást a törvényhatóságok számára, mivel a minisztérium szerint: „A törvénynek a rendezésre vonatkozó határozott

352 VARga 2006, 606-623.

353 MNL CSML IV.B. 252.b. 35.d.; MNL BM K150 117. 12183/1871.

354 MNL BM K150 117. 12183/1871.

355 STIPTA 1992b, 486.

356 MNL BM K150 117. 12183/1871.

357 TOMCSÁNYi 1940, 507-508.

358 KeCSKeméthy 1867,25-26. 
intézkedése minden bővebb utmutatást feleslegessé tevén." ${ }^{359}$ A megerősítésre beérkező munkálatok azonban nem igazolták a belügyminisztérium optimizmusát.

A minisztérium csupán néhány alapelvet fogalmazott meg a köztörvényhatóságok számára: „részemről csak azon reménynek adok kifejezést, miszerint a megye közönsége áthatva az átalakulás e nagy művének fontosságától, a megye rendezésére nézve oly tervezetet fog kidolgozni, és jóváhagyás végett hozzám mielőbb felterjeszteni, mely a gyors, és jó administratió biztosítása mellett, az ország illetőleg az adózó polgárok financziális érdekei megóvása iránti jogosult kivánalomnak is megfelelend." ${ }^{360} \mathrm{~A}$ főispánok számára ugyanezeket a követelményeket határozta meg a minisztérium a tervezetekkel kapcsolatban. Annyiban kaptak részletesebb utasítást, hogy felhívták figyelmüket arra, hogy „a személyes befolyásuk érvényesítésével” törvényhatóságuk kiemelkedő képességü, arra alkalmas férfiaiból állítsák össze a küldöttségeket. A törvény rendelkezései szerint ezzel szemben a közgyủlés jogosultsága volt a főispán elnöklete alatt működő küldöttségek összeállítása. A föispánnak küldött leiratból egyértelműen kitünik, hogy a kormányzat a föispánok útján kívánta érdekeit érvényesíteni. Emellett pedig a belügyminiszter kifejezte a határidők szoros megtartására és a tervezetek mielőbbi felterjesztésére irányuló kívánságát a törvényhatóságokat vezető főméltóságok számára, amelynek célja az volt, hogy a minisztériumi megerősítésre kellő idő álljon rendelkezésre. ${ }^{361}$

A leiratokat a szervezési munkálatok elkészítésére kötelezett köztörvényhatóságoknak és azok főispánjai számára is megküldték, így a vármegyéknek, a székely székeknek, a Jász-Kun, Hajdú, Nagy-Kikinda és Szepesi XVI városi kerületnek, valamint a szabad királyi városoknak. ${ }^{362} \mathrm{~A}$ Királyföldhöz tartozó törvényhatóságok számára azonban nem, mivel a szász egyetemhez tartozó kilenc szék és két vidék rendezéséről az 1870:XLII. tc.-ben az országgyülés nem rendelkezett. ${ }^{363} \mathrm{~A}$ törvény átmeneti és vegyes rendelkezései szerint a Királyföld átszervezését külön törvénynek kellett volna szabályoznia. Ennek megszületéséig azonban ideiglenes jelleggel a belügyminisztérium rendelete határozta meg a szász egyetem közigazgatásának müködését a Magyarország és Erdély egyesítéséről rendelkező 1868:XLIII. tc.-nek megfelelően. ${ }^{364}$

A belügyminiszter 1871. június 19-én újabb leiratot intézett a megyei, a széki, a vidéki és a kerületi törvényhatóságokhoz, amelyben ismételten felhívta a figyelmüket a tervezetek mihamarabbi elkészítésének fontosságára. ${ }^{365} \mathrm{~A}$ dokumentum útmutatást adott a törvényhatóságoknak ehhez, ugyanis a munkálatok eredményét nem összefoglaltan, hanem a köztörvényhatóságokról szóló törvény 91 . \$-ának pontjai szerint elkülönítve a szükségesnek tartott magyarázatokkal ellátva két-két példányban kérte a minisztérium felterjeszteni. Erre azért volt szükség, mert az egyes tervezeteket más-más belügyminiszteri tanácsos vizsgálta felül, így biztosítva a megerősítések egységességét.

\footnotetext{
359 MNL BM K150 117. 12183/1871. 
1871. szeptember 25-én Tóth Vilmos belügyminiszter udvarias jelzéssel szólította fel a 18 még késlekedő törvényhatóságot a tervezetek sürgős felterjesztésére. ${ }^{366}$ Egy hónappal később, október 26-án pedig Hont, Szabolcs és Turócz vármegye főispánját, Naszód vidék főkapitányát és a Szepesi XVI városi kerület grófát a minisztérium arra kérte, hogy táviratilag adjon tájékoztatást a szervezési munkálatokról. ${ }^{367}$

Látható, hogy a minisztérium kellö figyelmet fordított a szükséges tervezetek megszületésére, a késlekedő törvényhatóságokat igyekezett sürgetni. Az 1871. február 15-én Rajner Pál helyébe hivatalba lépő Tóth Vilmos belügyminiszterként is a szívén viselte az 1870:XLII. törvény végrehajtását, amelynek elkészítésében oroszlánrészt vállalt államtitkárként miniszterségét megelőzően. ${ }^{368}$

\subsection{A törvényhatósági tervezetek kidolgozása a küldöttségek által}

A belügyminisztérium számára megküldött tervezetek kísérőszövegeiben szórványosan az előző fejezetben részletezett rendeletek végrehajtása kapcsán is feltüntettek adatokat a vármegyék. A törvényhatóságok nem voltak kötelesek munkálataikról tájékoztatást küldeni a kormányzat számára, így a vizsgált kérdésekre adott vármegyei válaszok a minisztérium levéltári anyagában nem minden esetben találhatók meg. ${ }^{369}$

A 12183. számú leirat értelmében a belügyminiszter június 15-ére tüzte ki a törvényhatóságok szervezése ügyében eljáró vármegyei és kerületi közgyűlések összehívásának időpontját. Alsó-Fehér és Fejér vármegyében ennek megfelelően ebben az időpontban ülésezett az állandó bizottmány, azonban Zala és Csongrád vármegyék július 15-ét jelölték meg a küldöttséget összeállító vármegyei közgyülés időpontjaként. Zala vármegye úgy fogalmazott felterjesztésében, hogy ez az időpont volt a belügyminisztérium által kijelölt.

Érdekes kérdésként merül fel, hogy a törvényhatóságok miképpen nevezik meg önkormányzati szerveiket. Az 1848:XVI. tc. a vármegyék testületeit állandó bizottmányoknak hívta. Ez a kifejezés az 1870:XLII. tc.-et végrehajtó vármegyei munkálatokkal kapcsolatos rendelkezésekben nem szerepelt. Ott közgyülésként utalnak a törvényhatósági testületre, amelyet a köztörvényhatósági törvény a jövőre nézve törvényhatósági bizottságként határozott meg. Számos törvényhatóság ennek megfelelően közgyűlésként vagy a vármegye közönségeként nevezte meg a küldöttségi munkálatot elfogadó testületét. Mások pedig az állandó bizottmány kifejezés egy változatát alkalmazták. ${ }^{370}$ Alsó-Fehér vármegye egészen különös megoldást választva a képviselő bizottmány állandó bizottságaként jelölte

366 MNL BM K150 117.24502/1871.

367 MNL BM K150 117.27793/1871.

368 VARga 2007b; Csizmadia 1976, 119.

369 A vármegyék közgyülési (állandó bizottmányi) iratanyagában fellelhetők lehetnek ezzel kapcsolatos iratok is, így ez további kutatás tárgyát képezheti.

370 MNL BM K150 117.21161/1871. - Békés vármegye; 21272/1871. - Doboka vármegye; 21800/1871.

- Fogaras vidék; 118. 22592/1871.; 27001/1871. - Bereg vármegye; 23816/1871. - Gömör és Kis- 
meg az önkormányzati szervet. ${ }^{371} \mathrm{~A}$ bizottmány bevett elnevezés volt az önkormányzati szakbizottságokra a korszakban. ${ }^{372}$

A tervezetek kidolgozására létrehozott küldöttségek jellemzően nagy létszámúak voltak. Bereg vármegye 50 tagú, Alsó-Fehér vármegye 55 tagú, míg Fejér vármegye 90 tagú testületet állított össze a főispán vezetésével. Aranyosszék, Alsó-Fehér, Bereg, valamint Gömör és Kis-Hont vármegyék küldöttségeiket további albizottságokra bontva dolgozták ki tervezeteiket. ${ }^{373}$ Bereg vármegye a következőképpen osztotta meg két alválasztmánya között a munkát: az egyik felelt a törvényhatóságnak szolgabírói járásokra osztásáról és a választókerületek alakításáról, míg a másiknak a tisztikar, a segéd-, a kezelö- és a szolgaszemélyzet létszámáról, hatásköréről, a munkafelosztásról, a fizetések mennyiségéről és a napidíjak fokozatáról kidolgozandó tervezet elkészítése volt a feladata.

A küldöttségek által megalkotott tervezeteket, amelyeknél találunk erre vonatkozó utalást, jellemzően változatlanul vagy csekély változtatással fogadták el a vármegyék állandó bizottmányai. ${ }^{374}$ Csongrád és Alsó-Fehér vármegye emelte ki, hogy a küldöttség javaslatát nagy mértékben módosította a közgyülés. ${ }^{375}$ Alsó-Fehér vármegye a kísérőszövegben ehhez magyarázatot is füzött: a küldöttség által létrehozott 10 járást célszerütlennek tartották, így a fennálló, 13 közigazgatási egységből álló beosztást őrizték meg.

A törvényhatóságok a belügyminiszteri rendeletekre hivatkozva jártak el, így a 12183. számú leiratnak megfelelően két példányban és a 15251. számú szerint külön-külön pontonként felterjesztve küldték meg a belügyminisztérium számára megerősítésre a tervezeteket. ${ }^{376} \mathrm{~A}$ ragaszkodást a belügyminisztérium útmutatásához a leglátványosabban Zala vármegye kísérőszövege szemléltette: „És igy ezen indokoló előterjesztésünk kapcsában ’s figyelve a folyó évi junius hó 22 én 15251 sz. a. kelt magas leiratra, az abban kifejezett kivánalomnak megfelelő alakban van szerencsénk az elsorolt megye szervezési munkálatokat a 91\$a) b. c. és h. pontozatai szerint elkülönitve és 2 . egyenlő eredeti példányban ez alkalommal felterjeszteni." ${ }^{377}$

A törvényhatóságok legtöbbször a napidíjakra és/vagy fuvarköltségekre vonatkozó tervezetek felterjesztését mulasztották el. ${ }^{378}$ Emellett Bars vármegye első tervezetei közül

Hont vármegye; 28726/1871. - Hont vármegye; 22499/1871. - Kővár vidék; 22336/1871. - Veszprém vármegye.

371 MNL BM K150 118. 23346/1871.

372 ANTAL 2011, 202-204.

373 MNL BM K150 117.20171/1871.; 118. 23346/1871.; 22592/1871.; 23816/1871.

374 MNL BM K150 117. 17803/1871. - Csanád vármegye; 17808/1871. - Fejér vármegye; 22026/1871. - Felső-Fehér vármegye; 21798/1871. - Zala vármegye; 118. 23816/1871. - Gömör és Kis-Hont vármegye.

375 MNL BM K150 117.21068/1871.; 118. 23326/1871. - Alsó-Fehér vármegye.

376 MNL BM K150 117. 20171/1871. - Aranyosszék; 21799/1871. - Bars vármegye; 21161/1871. - Békés vármegye; 17803/1871. - Csanád vármegye; 21068/1871. - Csongrád vármegye; 21272/1871. - Doboka vármegye; 17808/1871. - Fejér vármegye; 118.23346/1871. - Alsó-Fehér vármegye; 23816/1871. Gömör és Kis-Hont vármegye; 22499/1871. - Kővár vidék; 22336/1871. - Veszprém vármegye.

377 MNL BM K150 117.21798/1871.

378 MNL BM K150 117. 17731Sz/1871. - Arad vármegye; 21799/1871. - Bars vármegye; 21161/1871. Békés vármegye; 17803/1871. - Csanád vármegye; 22026/1871. - Felső-Fehér vármegye; 21800/1871. 
a járásaiba beosztott községekről és azok lakosságszámáról szóló kimutatás hiányzott. ${ }^{379}$ A törvényhatóságok ezek megküldését később pótolták. Csanád és Zala vármegyék felterjesztették az 1872. évre vonatkozó költségvetésüket is azon célból, hogy ezzel igazolják azt, hogy képesek lesznek finanszírozni a létrehozott közigazgatási szervezeteiket. A belügyminisztérium azonban nem várta el ezeknek megküldését, így visszajuttatta azokat számukra. ${ }^{380} \mathrm{~A}$ munkálatokat jellemzően jelentés formájában küldték meg. ${ }^{381} \mathrm{Ez}$ alól kivételt képezett Alsó-Fehér vármegye, amely szabályrendeleteket alkotott az egyes kérdésekben. ${ }^{382}$

Több vármegye a 12183. sz. belügyminisztérium leiratnak nem csupán az alaki feltételekre vonatkozó rendelkezéseit vette figyelembe, hanem az abban megfogalmazott alapelvekre hivatkozva építették ki adminisztratív szervezetüket. ${ }^{383}$

- Fogaras vidék; 21798/1871. - Zala vármegye; 118.23346/1871. - Alsó-Fehér vármegye; 23816/1871.

- Gömör és Kis-Hont vármegye; 28726/1871. - Hont vármegye.

379 MNL BM K150 117.21799/1871.

380 MNL BM K150 117. 17803/1871. - Csanád vármegye; 21798/1871. - Zala vármegye.

381 MNL BM K150 117. 20171/1871. - Aranyosszék; 17803/1871. - Csanád vármegye; 21800/1871. - Fogaras vidék; 21798/1871. - Zala vármegye; 118. 22592/1871. - Bereg vármegye; 23816/1871. Gömör és Kis-Hont vármegye; 22336/1871. - Veszprém vármegye.

382 MNL BM K150 118.23346/1871.

383 „Munkálatunknak igyekeztünk azon alakot adni, hogy annak nyomán becsületes, értelmes és munkás közegek által az önkormányzatilag gyakorolt közigazgatás felfrissitessék, az ügymenet minden hivatalnál a lehetó legnagyobb gyorsaságra emeltessék, 's a felelósség általános kiterjesztése mellett a fó" czél, hogy t. i. a közigazgatás gyors pontos és mocsoktalan legyen - eléressék." MNL BM K150 117. 17803/1871. - Csanád vármegye; 21272/1871. - Doboka vármegye. 


\section{A JÁRÁSOK TERÜlETI BEOSZTÁSA A TÖRVÉNYHATÓSÁGOK SZERVEZÉSI MUNKÁLATAIBAN}

Az általam feldolgozott törvényhatóságok szervezési munkálataival illusztrálom a járások létrehozása kapcsán felmerült problémákat. A járási beosztással kapcsolatos szervezési munkálatok színvonala egyenetlen volt. Néhány vármegye részletesen indokolta megoldásait, ${ }^{384}$ sőt néhány törvényhatóság még térképet is mellékelt. ${ }^{385} \mathrm{~A}$ vármegyék többsége viszont csupán egy-két mondatos magyarázattal szolgált a járási beosztásához. ${ }^{386}$ Fogaras vidék és Zala vármegye viszont nem tartotta szükségesnek az erről szóló tervezet elkészítéséhez vezető indokokat feltárni. ${ }^{387}$ Arad és Hont vármegye hozzájuk hasonlóan járt el, azonban a belügyminisztérium korrekcióra irányuló leiratát követően mégis indokolták döntésüket ezáltal elősegítve a minisztériumi megerősítést. ${ }^{388}$

\subsection{A „járás” elnevezés partikuláris fogalomhasználatának egységesítése}

A vármegyék területüket 1848 előtt és 1861-et követően is különböző közigazgatási egységekre bontották, amelyeket változatos elnevezésekkel illettek. A jogalkotó az egységesítés érdekében a köztörvényhatósági törvényben a szolgabíró illetékességi területének megnevezésére a 61 . \ értelmében a járás fogalmát használta, ${ }^{389}$ míg a vegyes és átmeneti rendelkezések között pedig a törvényhatóságnak szolgabírói járásokra való osztására hívta fel a vármegyéket. A szolgabírák működési területére ennek megfelelően majd minden vármegye egységesen szolgabírói járásként vagy csak járásként utalt. ${ }^{390}$

384 MNL BM K150 117. 21799/1871. - Bars vármegye; 21161/1871. - Békés vármegye; 21068/1871, 27282/1871. - Csongrád vármegye; 22026/1871. - Felső-Fehér vármegye; 118. 22336/1871. - Veszprém vármegye.

385 MNL BM K150 117.21272/1871. - Doboka vármegye; 118. 22499/1871. - Kővár vidék.

386 MNL BM K150 117. 20171/1871. - Aranyosszék; 17803/1871. - Csanád vármegye; 17808/1871 - Fejér vármegye; 118. 23346/1871., 31726/1871. - Alsó-Fehér vármegye; 23816/1871. - Gömör és Kis-Hont vármegye; 22592/1871. - Bereg vármegye. BoNCZ, 1876, 128e).; FÉsüs 1880, 64. 27282/1871. - Csongrád vármegye; 21272/1871. - Doboka vármegye, 17808/1871-Fejér vármegye; 22026/1871. - Felső-Fehér vármegye, 21800/1871. - Fogaras vidék; 22226/1871. - Krassó vármegye; 21797/1871. - Szepes vármegye; 21949/1871. - Temes vármegye; 20991/1871. - Trencsén vármegye; 21798/1871. - Zala vármegye; 118.31726/1871-Alsó-Fehér vármegye; 23816/1871-Gömör és Kis-Hont vármegye; 22326/1871. - Komárom vármegye; 22499/1871. - Kővár vidék; 25309/1871. - Küküllő 
Aranyosszék olyan szempontból tért el ettől, hogy az erdélyi szolgabírákra használt terminológiához illeszkedo” „dulló járás” elnevezést is alkalmazta a szolgabírói járás mellett. ${ }^{391}$ Nagy-Kikinda kerület megtarthatta az általa alkalmazott tanácsnoki járás elnevezést, amely igazodott ahhoz, hogy tervezetükben a szolgabírákat tanácsnokoknak titulálták. ${ }^{392}$ Ezt a két megoldást a belügyminisztérium is jóváhagyta, vagy legalábbis a megerösítés során nem kifogásolta.

Arad vármegye viszont a szolgabírói illetékességi területeket konzekvensen minden tervezetében szolgabírói kerületeknek titulálta. ${ }^{393} \mathrm{E}$ hiba korrekciójára konkrétan egyetlen alkalommal sem szólították fel, annak ellenére sem, hogy a törvényhatóságnak három, járásaival kapcsolatos tervezetet is be kellett terjesztenie. A belügyminisztérium csupán az utolsó alkalommal beérkezett, a községek járási beosztását tartalmazó tervezeten javította át az összes kerület megnevezését járásra, amelyet ugyan megküldtek a vármegyének, de ennek ellenére is különös, hogy a belügyminisztérium leiratban nem figyelmeztette a vármegyét a helytelen fogalomhasználatra. ${ }^{394}$ Fejér vármegye szintén kerületként nevezte meg a községek beosztását tartalmazó tervezetében szolgabírái illetékességi területét, amelyet szintén csupán áthúzással korrigált a minisztérium. ${ }^{395}$

A szolgabírák illetékességi területének kerületként való megjelölését Bars, Sáros és Hont vármegye is alkalmazta első tervezeteiben, azonban a járásra vonatkozó egységes fogalomhasználatban ez nem okozott zavart, mivel ezek a járási szint alatti területi egységként jelentek meg. ${ }^{396}$ Hont vármegye esetében a közigazgatás alsó középszintjének egységesítését megvalósító második vármegyei felterjesztésében volt megfigyelhető némi terminológiai bizonytalanság, ugyanis a tervezethez küldött kisérőszövegben a törvényhatóság közönsége kerületként jelölte meg a szolgabírák illetékességi területét, viszont az egyes járásokhoz tartozó települések beosztását és a lakosságszámot feltüntető tervezetben már helyesen a járás elnevezést alkalmazták. Valószínűsíthetően ennek következtében a belügyminisztérium a második tervezetre adott válaszában nem kívánta a fogalomhasználat egységesítését. ${ }^{397}$

Az 1870:XLII. tc. 61. \$-ában, valamint a vegyes és átmeneti rendelkezések 91. \$-ában is úgy fogalmazott a jogalkotó, hogy a szolgabírói járás megnevezés mögött zárójelben a szakaszok szó szerepelt. Emiatt érdekes kérdésként merül fel, hogy a jogszabályban szereplő „szakasz” alatt mit értett a törvényhozó és vajon miképpen értelmezte a jogalkalmazó. A törvényben erre vonatkozóan nem található iránymutatás, emiatt érdemes a jogszabály értelmezésére is vállalkozó tervezeteket és az ahhoz kapcsolódó belügyminisztériumi megerösítéseket megvizsgálni a kérdés megoldásához.

vármegye; 28989/1871. - Nógrád vármegye; 22336/1871. - Veszprém vármegye; 25636/1871. Zaránd vármegye.

MNL BM K150 117.20171/1871.

MNL BM K150 118.31986/1871. 
Bereg vármegye első tervezetében az öt általa létrehozott járása közül kettőt további két-két szakaszra osztott, amelyek együttes megnevezésére a szolgabíróság fogalommal operált. ${ }^{398}$ Egyértelmü terminológia azonban nem figyelhető meg az esetükben, ugyanis a második felterjesztett tervezetükben az összes szolgabírói illetékességi területet szakaszként jelölték meg. ${ }^{399}$ Ezt végül a belügyminisztériumi tanácsos akképpen korrigálta, hogy miután ragaszkodtak a szakaszok fenntartásához, így azok területi beosztása járás néven fennmaradhatott. ${ }^{400}$

A belügyminisztérium tehát nem adott magyarázatot a szakasz terminológia értelmezésére és a vármegyei tervezetekben sem engedélyezte ennek használatát. Amint majd a későbbiekben látható lesz, a szolgabírák elnevezésének egységesítésénél sokkal határozottabban léptek fel a belügyminisztériumi tanácsosok, a járások esetében a szakasz vagy kerület elnevezéseket mintegy mellékesként javították csupán.

\subsection{Egyszintü járási beosztás}

A fogalomhasználat mellett az évszázados, központi szabályozást nélkülöző fejlődésnek köszönhetően az önkormányzati igazgatási szervezet felépítése is nagyfokú partikularizmust mutatott. A rendi korban ugyanis a járásokat a legtöbb vármegye további közigazgatási egységekre osztotta, amelyeket a vármegyék fenntartottak a közigazgatás 1861 . évi visszaállítása alkalmával is. ${ }^{401}$ Ez alól kivételt képeztek Békés és Csongrád vármegyék, amelyek rendezés előtti közigazgatási szervezetében szintén csak járások találhatóak. ${ }^{402}$ Erdélyben szintén egyszintű volt az alsó középszintű közigazgatási szervezet. ${ }^{403} \mathrm{Az}$ egységesítés érdekében a belügyminisztériumi tanácsosok különös figyelmet fordítottak az eltérő megoldások korrigálására a törvényhatósági tervezetekben.

Bereg vármegye öt szolgabírói járásra osztotta fel területét, de két járásának kiterjedését aránytalanul nagynak tartotta, ezért azokból két-két szakaszt hozott létre, amelyek élére szintén szolgabírákat állított. A belügyminisztériumnak felterjesztett javaslatban azzal kísérelték meg elkerülni annak hangsúlyozását, hogy eltértek az egységes alsó középszintü területbeosztás követelményétől, hogy egységesen szolgabíróságoknak nevezték a szolgabírák illetékességi területeit, így összesen hét szolgabíróságot létesítettek. ${ }^{404} \mathrm{~A}$ belügyminisztérium leiratában elöször csupán a járások számának csökkentését kérte, mivel 
azonban a megye közönsége ragaszkodott eredeti tervezetéhez, így a belügyminisztérium az újabb felterjesztést olyan módon hagyta jóvá, hogy a szakasz elnevezést elhagyva Bereg vármegye egységesen hét szolgabírói járással rendelkezik. ${ }^{405} \mathrm{~A}$ belügyminisztériumi tanácsos azzal indokolta döntését, hogy „a szolgabírói járásoknak szakaszokra illetőleg aljárásokra osztása, a törvény szellemével ellenkezik". ${ }^{406}$

Hont vármegye négy járást hozott létre, amelyeket szabályszerűen három-három kerületre osztott fel. Ez a szervezeti megoldás a megye régi szervezetének belügyminisztériumi jellemzése alapján a régi közigazgatási szervezet megőrzését jelentette volna, azzal a különbséggel, hogy az 1870. évben működő közigazgatási szervezetben a négy járás élén szolgabírák álltak és a kerületeket alszolgabírák vezették, míg az új szervezeti megoldás 12 szolgabírát állított a kerületek élére és a föszolgabírákat elhagyta. ${ }^{407} \mathrm{~A}$ belügyminisztérium 1871. november 8-án kelt leiratában a törvénnyel ellenkező megyei beosztás átdolgozását kérte. ${ }^{408}$ Hont vármegye évnegyedes közgyűlése a határozott kérés ellenére fenntartotta a kerületek számát az addigi járások elhagyásával. ${ }^{409}$ Ezzel egyszintűvé vált a megyén belüli közigazgatási szervezet, bár helytelen fogalomhasználattal, de ezt, ahogy már említésre került, a felterjesztés másik részében korrigálta a törvényhatóság. Minden bizonnyal ennek köszönhető, hogy a belügyminisztérium a második tervezetre adott válaszában végül nem kívánta a járási szervezet ismételt átalakítását, amelyet a vármegyének küldendő leirat előfogalmazványából csupán a végső szöveget ellenőrző tanácsos húzott ki. A javított szövegrész ugyanis helytelenül még azt tartalmazta, hogy a vármegye továbbra is ragaszkodik ahhoz, hogy négy járást és 12 kerületet hozzon létre. ${ }^{410}$

Honthoz hasonlóan járt el Bars vármegye is, amely a régi szervezeti kereteket fenntartva a járásokat az alszolgabírák illetékességi területét meghatározó kerületekre kívánta felosztani, de a vármegye ezen elképzelésére az első tervezetében csupán mellékesen a szolgabírák hatásköri leírásánál történt utalás, mivel elmulasztották a járások községekre lebontott felosztását felterjeszteni. ${ }^{411}$ A megerősítést végző minisztérium az első tervezet beérkezését követően a szokott formula keretében kifejezte az egyszintü közigazgatási szervezet létrehozására vonatkozó kívánalmát, ${ }^{412}$ amelyet a törvényhatóság végrehajtott a községek járási beosztásának benyújtásával. 413

MNL BM K150 118. 22592/1871.; 27001/1871.

MNL BM K150 118. 27001/1871.

MNL BM K150 118. 28726/1871.

408

"A törvényhatóság területének felosztását elötünteto" tervezetet, azonban, mely szerint a terület a törvény világos rendelete ellenére 4 járásra illetöleg 12 kerületre osztatott föl, mint a törvénybe ütközött helyben nem hagyhatván: azt a megye közönségének ujbóli megállapitás végett ide mellékelten vissza küldöm." - MNL BM K150 118. 28726/1871.

MNL BM K150 118.31986/1871.

410

411 „A járási tisztviselók hatáskörére vonatkozó utasitás 1.5 a) szerint a járási közigazgatás elsö tisztviselönek foszolgabiro czim adatik, sjogában álland: járási területét az alszolgabirák között beosztani, kik a nekik kiosztott kerületben hivatalos helyiséget kötelesek tartani, s abban naponként eleve meghatározott orákban a közigazgatási ügyek elintézése végett megjelenni." - MNL BM K150 117.21799/1871.

412 MNL BM K150 117.21799/1871.

413 MNL BM K150 117.28287/1871. 
Sáros vármegye eredetileg hat járást alakított ki, amelyeket két-két kerületre osztott. A belügyminisztériumi megerősítés a vármegye közönsége számára jelezve a törvénnyel ütköző megoldást 12 szolgabírói járásként fogadta el Sáros vármegye járási beosztását. ${ }^{414}$ Szabolcs vármegyét szintén azért figyelmeztette a tervezeteket megerősítő tisztviselö, mert a járásokat a közgyűlés további szakaszokra osztotta fel. ${ }^{415}$

A jogalkotó egységes felépítésű és terminológiával rendelkező alsó középszintű közigazgatást kívánt kialakítani, így a járások további alegységekre bontását a belügyminisztériumi tanácsosok elutasították. A belügyminisztérium válaszleirataiban több alkalommal is figyelmeztette a törvényhatóságokat, hogy az aljárások létrehozását kifejezetten ellenzi. A korábban gyakran háromszintű közigazgatási szervezetet ezáltal egységesen kétszintűvé alakították.

\subsection{A járások kialakítását befolyásoló tényezők}

Az 1870:XLII. tc. rendelkezése szerint a törvényhatóságoknak a területeik szolgabírói járásokra osztását az országos választókerületek figyelembevételével kellett elvégeznie. Az országos választókerületeket az országgyülési követeknek népképviselet alapján való megválasztásáról szóló 1848:V. tc. hozta létre. ${ }^{416} \mathrm{Az} 5 . \$$ B) pontja alapján az országgyülés meghatározta, hogy az egyes megye, szabad kerület és város mennyi képviselöt választhat. A konkrét választókerületek területének meghatározására a területi önkormányzatok váltak jogosulttá, amelyek még 1848-ban végrehajtották a törvény rendelkezéseit. ${ }^{417} \mathrm{Az}$ elfogadott választókerületi beosztásokat pedig az 1870:XLII. tc. járások meghatározására vonatkozó szabályozásához hasonlóan a belügyminisztérium számára kellett felterjeszteni, de ebben az esetben a megerősítésre nem volt szükség.

A törvény előkészítése folyamán a kerületi ülésen vita tárgyát képezte, hogy átlagban hány lakos legyen jogosult egy képviselőt választani. Az eredeti tervezet azt javasolta, hogy 30000 főre jusson egy képviselő. Andrássy Gyula Zemplén vármegyei képviselő ezt kívánta 40000-re módosítani, de ezt elvetették, így az országgyưlési vita során is az átlagosan 30000 fós választókerületek kerültek elfogadásra. ${ }^{418} \mathrm{~A}$ vármegyék és a kiváltságos kerületek esetén a választókerületek meghatározásánál a saját jogon képviselöt küldő városokat nem kellett a népességszámba számítani. Az országos választókerületek lakosságszámhoz igazítása Erdélyben viszont elmaradt az áprilisi törvények megalkotásakor,

\footnotetext{
414 „Miután az elöidézett törvény a törvényhatóságoknak nem szakaszokra vagy kerületekre, hanem határozottan szolgabirói járásokra osztását rendeli, a sz[olga]birói „kerület" elnevezés "járással" felcserélendō." - MNL BM K150 117. 20826/1871.

415 „A törvényhatóság területének felosztását elötünteto” tervezetet (...) azon oknál fogva mert a törvény nem aljárásokról hanem járásokról tesz emlitést, meg nem erösithetem." - MNL BM K150 118. 32644/1871.

416 Ruszoly 1986, 219.

417 „Figyelembe véve azonban, hogy az országos választó kerületeknek, a megye területén 1848-ban történt beosztása;" - MNL BM K150 118. 22336/1871. - Veszprém vármegye.

418 Ruszoly 1996, 291-293.
} 
így erre csak a dualizmus során kerülhetett sor a választójogi reform alkalmával, amely azonban csak az 1870:XLII. tc. elfogadását követően valósulhatott meg. ${ }^{419}$

A közigazgatási területi beosztások másik lehetséges mintája az igazságszolgáltatási szervezet lehetett volna. A járásbíróságok területi illetékességét azonban még ekkor nem határozták meg, így irányadóul csak az országos választókerületeket állapíthatta meg az országgyủlés. ${ }^{420}$ Ezzel minden bizonnyal az lehetett a céljuk, hogy a törvényhatóságok egy irányszámot kapjanak arra nézve, hogy hány szolgabírói járást alakítsanak ki. Kővár vidék tervezetében ennek megfelelően úgy vélte, hogy annyi szolgabírói járást kellene létrehoznia a törvényhatóságoknak, ahány országos választókerülettel rendelkeznek. ${ }^{421}$

Bars vármegye a járási felosztás indoklásában rámutatott azokra az okokra, amelyek a törvényhozót arra késztethették, hogy a választókerületek figyelembevételéről rendelkezzen a törvényben. Két okot jelöltek meg: egyrészt amennyire lehetséges a közigazgatási, a törvénykezési, a pénzügyi és az országos választókerületek egybeessenek; másrészt a szervezési munkálatokat megelőzően a járások száma a nagy kiterjedésű megyékben kevesebb volt, mint amennyit a népességszám miatt megkívánt volna a célszerü közigazgatás. Emiatt a törvényhozó az országos választókerületek figyelembevételének kötelezettségével nyújtott zsinórmértéket e vármegyék számára. A véleményes javaslat Bihar, Temes és Torontál vármegyét említette példaképpen. ${ }^{422}$

A vizsgált tervezeteket áttekintve megállapítható, hogy a törvényhatóságok jelentős része figyelmen kívül hagyta az országos választókerületi beosztást. A vizsgált vármegyék közül csupán Fejér, Szepes, Hont, Csanád, Nógrád, Komárom és Veszprém vármegye, valamint Kővár vidék vette a járási beosztás alapjául az országos választókerületeket. ${ }^{423}$ A legtöbb vármegye indoklásában egyszerủen eltekintett ennek tekintetbevételétől. ${ }^{424}$ Bereg vármegye pedig ugyan a tervezet bevezetőjében úgy fogalmazott, hogy a szolgabírói járásokat „tekintettel a választókerületekre és a járásbiróságokra” hozta létre, azonban az indoklásban már nem szerepeltette a választókerületek figyelembevételét, és a járások sem mutatnak az országos választókerületekhez hasonló képet. ${ }^{425}$ Sáros, Krassó, Trencsén, Bars, Békés, Pozsony, Szabolcs és Zaránd vármegye pedig visszautasította azt az ehhez füzött indoklásában. ${ }^{426}$ Különös, hogyha nem is egy szigorúan vett törvényi kötelezettséget utasítottak ezzel vissza a törvényhatóságok, de ebben az esetben önkormányzati autonómiájuknál fogva a törvényhozó rendelkezéseivel szembehelyezkedtek.

\footnotetext{
419 PAP 2014, 242-244.

420 Ruszoly 2013, 29.

421 MNL BM K150 118. 22499/1871.

422 MNL BM K150 117.21799/1871.

423 MNL BM K150 117. 17803/1871.; 17808/1871.; 21797/1871; 118. 22499/1871; 22336/1871.; 22326/1871.; 28989/1871.; 31986/1871.

424 MNL BM K150 117. 17731/1871; 17731Sz/1871.; 32702/1871. - Arad vármegye; 20171/1871. Aranyosszék; 21068/1871. - Csongrád vármegye; 21272/1871. - Doboka vármegye; 22026/1871. Felső-Fehér vármegye; 21800/1871. - Fogaras vidék; 21798/1871. - Zala vármegye; 118. 22592/1871. - Bereg vármegye; 23816/1871. - Gömör és Kis-Hont vármegye.

425 MNL BM K150 118.22592/1871.

426 MNL BM K150 117. 20826/1871.; 22226/1871.; 28525/1871.; 21799/1871.; 21161/1871; 118. 26616/1871.; 28391/1871.; 25636/1871.
} 
Az országos választókerületeket a beosztásuk alapjául elfogadó törvényhatóságok esetében is csupán Szepes és Komárom vármegye alakított ki annyi szolgabírói járást, ahány választókerületre a vármegye területét felosztották. ${ }^{427}$ Fejér vármegye az öt országos választókerületből hat járást hozott létre, mivel a bodaiki kerület területe és népessége a kétszerese volt a többi választókerületnek, így abból két szolgabírói járást állítottak fel. ${ }^{428}$ Csanád vármegye pedig két választókerületét csupán a beosztás alapjának tekintve, a vármegyét négy járásra osztva két-két járást hozott létre belölük. ${ }^{429}$ Konvár vidék ehhez hasonlóan szintén két választókerületét két-két járásra osztotta fel. ${ }^{430}$

Veszprém vármegye ugyan kijelentette, hogy a törvényi kötelezettségnek megfelelően az országos választókerületek figyelembevételével tervezték meg a járásaikat, azonban a megyei állandó bizottmány az indokolásban inkább azt magyarázta, hogy milyen okokból nem támaszkodhattak erre a szervezet kialakítása során. A választókerületek még 1848-ban történt közgyűlési létrehozását „rögtönzésnek” titulálták, amelyet az azóta bekövetkezett "közlekedés és egyéb helyi viszonyok" miatt is szükséges átalakítani. ${ }^{431}$

Hont vármegye állítása szerint a földrajzi viszonyok által biztosított lehetőségekhez képest szintén tekintettel volt az országos választókerületekre, azonban alsó középszintü adminisztrációs szervezetük felépítésén ez nem igazán érzékelhető. A megye három országos választókerülettel rendelkezett, ehhez képest 12 szolgabírói kerületre osztotta fel területét. Érdemes ehhez még hozzáfüzni, hogy a vármegye közönsége csupán a belügyminisztérium által első alkalommal meg nem erősített tervezet ismételt benyújtásához füzött indoklásban hivatkozott az országos választókerületek alapján végzett munkálatokra. ${ }^{432}$

Az országos választókerületek figyelmen kívül hagyását jellemzően a vármegyék két indokkal igazolták. Egyrészt azzal érveltek, hogy a vármegye területébe szabad királyi város ékelődik be, amely az 1870: XLII. tc. értelmében köztörvényhatósággá alakult, így a vármegyei törvényhatóságtól függetlenné vált. Emiatt a vármegye területén belül önálló területtel rendelkeztek, amelynek a járás területébe való beosztását a jogszabály nem tette lehetővé. A lakosságszáma és a területe azonban az országos választókerületbe beszámított. ${ }^{433}$

A közigazgatási szervezet átszervezésének átgondolatlanságát mutatja azonban, hogy Békés vármegye ezzel ellentétes érveléssel utasította el azt, hogy az országos választókerületeknek megfelelően szervezze át a szolgabírák illetékességi területeit. Több megyebeli város ugyanis saját képviselőválasztási joggal rendelkezett az 1848:V. tc. alapján, amelynek maradandó megalkotását változékony és hiányosnak ismert alapra fektetni hajlandók nem voltunk, 's habár a törvény rendeletére lehetöségig tekintettel lenni kivántunk is, azt, érintett okoknál fogva egyedüli irányadóul el nem fogadhattuk." - MNL BM K150 118.22336/1871.

432 „Miután a mennyire csak hegyes völgyes és vizekkel boritott megyénkben a topographiai akadályok engedték, tekintettel voltunk az országgyülési választókerületekre is." - MNL BM K150 118. 31986/1871.

433 MNL BM K150 117. 20826/1871. - Sáros vármegye; 118. 26616/1871. - Pozsony vármegye. 
köszönhetően az országos választókerületek kialakításánál nem vették figyelembe őket, azonban a járási szervezet kialakításánál már nem mellőzhették tekintetbevételüket. ${ }^{434}$

Másrészt viszont azzal magyarázták az erre vonatkozó kötelezettség figyelmen kívül hagyását, hogy az országos választókerületek felosztása nem a közigazgatás igényeinek megfelelően történt. A közigazgatás ugyanis gyakoribb érintkezést igényel, míg a választókerületekre csupán három évente egy cselekmény esetén van szükség, ezért a választókerületek meghatározásánál csupán az egyenlő lakosságszám elérése volt a cél. ${ }^{435}$

Az országos választókerületek helyett a vármegyék tekintélyes része a járásbírósági beosztáshoz igyekezett igazítani a kialakítandó járásokat. A törvény megszületésekor még a járásbíróságok illetékességi területének meghatározása hiányzott, így annak figyelembevételét nem tehette törvényi kötelezettséggé a jogalkotó. A járásbíróságokra vonatkozó szabályozás csupán az első folyamodású királyi törvényszékek és járásbíróságok életbeléptetéséről szóló 1871:XXXII. tc.-kel került megalkotásra. ${ }^{436}$

A törvénycikk elfogadása egybeesett a közigazgatási tervezetek elkészítésének időszakával. ${ }^{437}$ Előbb a Képviselőház által kiküldött 25 -ös bizottság jelentése került nyilvánosságra 1871. május 1-jén, amely tartalmazta a bizottság által meghatározott törvényszéki és járásbírósági székhelyeket. A felvázolt javaslat eredményeképpen az országgyűlés határozta volna meg a székhelyeket, az igazságügyi minisztérium pedig az egyes székhelyekhez tartozó illetékességi területeket a törvényhatóságok és a községek meghallgatásával szabta volna meg. ${ }^{438}$

A központi bizottság május 10-ei jelentése ezzel szemben elvetette a székhelyek országgyűlési meghatározását, és ezt a feladatot a kormányhoz utalta. ${ }^{439}$ A törvény így a járásbíróságok illetékességi területének és székhelyének megállapítását az igazságügyi minisztériumra bízta. A kormány pedig az 1871. július 10-én kelt rendeletével határozta meg a járásbíróságok és a törvényszékek székhelyeit. ${ }^{440}$

Bihar vármegye a közigazgatási beosztását a járásbíróságok székhelyeihez kívánta igazítani. Emiatt már 1871. június 19-én a tervezetek elkészítésére hivatott küldöttség kiküldését követően jelezte a belügyminisztériumnak, hogy a járásbíróságok területi beosztásáról szóló megállapodás közlését kéri. Bihar vármegye közönsége azzal indokolta kérését, hogy ugyan nem kötelezö a közigazgatási beosztás kialakításánál a törvénykezési

434 „Illetve az 187042 t.cz. 91\$-nak a.) pontjában foglalt azon rendelkezést, miszerint a törvényhatóság szolgabirói járásokra felosztása az országos választó kerületekre való tekintettel történjék: a törvény e rendelkezése egészben kivihetö nem vólt; mert egyes e megyebeli városok külön képviselö küldési joggal birnak, sezen városok közbenesöségük folytán az eddigi felosztás megváltoztatását akadályozzák; a törvény érintett intentiojjának pedig részben már elég van téve a jelenlegi felosztás azon igénye által, hogy az imént érdeklett követküldési joggal felruházott városok egyszersmind szolgabirói székhelyek is." - MNL BM K150 117. $21161 / 1871$.

435 MNL BM K150 117.28525/1871. - Trencsén vármegye; 22226/1871. - Krassó vármegye; 21799/1871.

- Bars vármegye.

436 BALOgh 2017, 46-48.

437 MÁTHÉ 1982, 153-155.

438 KI 1869. IX. k. 229-242.

439 KI 1869. IX. k. 336-340.

440 39. ministeriumi rendelet. 
beosztás figyelembevétele, de a lakosság érdeke az, hogy a kettő illetékességi területe egybeessen. A belügyminisztérium erre azt válaszolta, hogy „ez érdemben jelenleg tárgyalások vannak folyamatban", de ezek végeztével értesíteni fogja a törvényhatóságot. ${ }^{441}$ Egy hónap elteltével július 19-én Bihar vármegye figyelmeztette a belügyminisztériumot, hogy a küldöttség munkáját késlelteti a járásbírósági beosztás hiánya, mivel a járások meghatározásához nélkülözhetetlenek ezek az adatok. A belügyminisztérium ennek kapcsán leiratában kifejtette, hogy az igazságügyi minisztérium felhívta a vármegyéket javaslataik elöterjesztésére, így a belügyminisztérium az ügyet elintézettnek tekinti. ${ }^{442} \mathrm{Az}$ igazságügyi minisztérium valóban lehetőséget biztosított Bihar vármegye számára már az 1871. év elején a törvénykezési szervezettel kapcsolatos javaslataik előterjesztésére. ${ }^{443}$ A belügyminisztérium indoklása ennek ellenére „sántított”, mivel ez csupán javaslat volt, a végső szót az igazságügyminiszter mondta ki a kérdésben.

Nem csupán Bihar vármegye kívánta azonban a törvénykezési beosztást figyelembe venni a járási szervezet kialakításakor, a vizsgált törvényhatóságok közül nyolc esetben is felmerült a járásbírósági beosztáshoz való igazodás igénye, azonban csupán öt járási beosztás egyezett meg a legalsóbb szintű törvénykezési szervezettel. Pozsony, Békés, Veszprém, Bereg, valamint Gömör és Kis-Hont törvényesen egyesült (t. e.) vármegye a járásbírósági beosztással megegyező alsó középszintű közigazgatási szervezetet hozott létre. ${ }^{444}$ Bereg vármegye azonban nem a járásbírósági beosztással tökéletesen egyező járásokat szervezett, hanem a nehéz közlekedési viszonyokkal, a természeti adottságokkal és a szolgabírák munkaterhének nagyságával indokolva két járásbírósági kerületet is kettéosztott. ${ }^{445}$

Az alsó középszintű közigazgatási szervezet járásbíróságokhoz igazítását Pozsony vármegye azzal magyarázta, hogy ezzel sok költségtől és időveszteségtől óvják meg a lakosságot, ${ }^{446}$ valamint Bereg vármegyével megegyezően arra hivatkoztak, hogy a törvénykezés és közigazgatás újonnan való elválasztása miatt az alsóbb néprétegek még nem tudják elkülöníteni az igazságszolgáltatási és a közigazgatási feladatokat, ezért is előnyös, ha a két szervezetrendszer beosztása azonos. ${ }^{447}$ Veszprém vármegye szintén a lakossági igények

441 MNL BM K150 117. 15501/1871.

442 MNL BM K150 117. 18839/1871.

443 ANTAL 2011, 185-186.

${ }_{444}$ MNL BM K150 117.21161/1871. - Békés vármegye; „a megye közigazgatási tekintetben a járásbirósági kerületekkel egy formán, ugyanazon beosztással, 5 szbirói járásra osztassék fel." - 118. 23816/1871. Gömör és Kis-Hont vármegye; 26616/1871. - Pozsony vármegye; 22592/1871. - Bereg vármegye; 22336/1871. - Veszprém vármegye.

445 „Minthogy azonban a munkácsi és beregszászi járásbiróságok a többieknél aránytalanul nagyobbak, a munkácsi a Latorcza folyó áradásai által úgy szólva: két felészakittatik, 's igy az ambulansnak mondható szolgabiró egész járásának összefüggö beutazásában olykor olykor gátolva lenne; a beregszászi járás szolgabiráját pedig a megye nagy részének érdekében a Tisza folyó védmunkálatainak figyelemben tartása igen elfoglalja, ennélfogva a munkácsi és beregszászi járást két két szakaszra [...] véleményezzük felosztani." MNL BM K150 118.22592/1871.

446 MNL BM K150 117.26616/1871.

447 MNL BM K150 117.26616/1871. - Pozsony vármegye; „Tekintve azt, hogy a lakosság egy része tájékozatlan az iránt, vajjon ügye a szolgabiró vagy a járásbiró elébe tartozik stekintve azt is, hogy az árvaügyek körében felmerüló jogi esetek a törvénykezés körébe tartoznak, sigy tehát kivánatos, hogy az egyik hatóságot 
miatt kívánta a törvénykezési és az adminisztratív körzeteket összhangba hozni, valamint a járásbírósági beosztást maradandóbbnak tartották az országos választókerületeknél. ${ }^{448}$ Ez a megállapítás meglepő, mivel a bíráskodási szervezetet az igazságügyminisztérium alakította ki, míg az országos választókerületek szervezése a vármegye önkormányzati szervének hatáskörébe tartozott. Veszprém vármegye eme elvi megállapításához akkor is ragaszkodott, amikor az Igazságügyminisztérium átszervezte a korábbi járásbírósági beosztást, és az első koncepciótól eltérően Várpalotára nem telepítettek elsőfokú bírói fórumot. Ennek következtében az 1871. augusztus 31-ei megyei állandó bizottmányi közgyủlésen a tervezett várpalotai járás községeit a zirczi, devecseri, enyingi és veszprémi járások között osztották szét. ${ }^{449}$

Arad vármegye már 1871. július 3-án megküldte a járási beosztást tartalmazó tervezetét a belügyminisztérium számára, amelyben teljes mértékben az országgyűlés 25-ös bizottsága által megállapított járásbírósági székhelyekhez igazította a szolgabírói járásokat. ${ }^{450} \mathrm{~A}$ bizottság által kimunkált tervezetet azonban az országgyülés végül elvetette, aminek köszönhetően átalakultak a járásbíróságok székhelyei és illetékességi területei. A vármegye főispánja így még a belügyminisztériumi megerősítést megelőzően július 17-én kérte a tervezet visszaküldését. ${ }^{451}$ Arad vármegye ezt követően a törvénykezési beosztás figyelmen kívül hagyásával a vármegye számára meghatározott hét járásbíróság mellé először tizenkettő, majd a belügyminisztériumi figyelmezetés következtében tizenegy közigazgatási járást szervezett. ${ }^{452}$

Trencsén vármegye Aradhoz hasonló dilemmával szembesült, a járásbíróságokhoz kívánta igazítani a szolgabírák illetékességi területét, de az általuk tervezett kilenc járásbíróság helyett az igazságügyminiszter csak nyolcat hozott létre a vármegye területén. A szervezési munkálatok során emiatt megmaradtak az általuk tervezett kilenc járásnál az alsó középszintű közigazgatás létrehozásánál. ${ }^{453}$ Krassó vármegye sem kívánta figyelembe venni a járásbírósági székhelyeket, mivel a kormányzat az általuk javasolt hat alsófokú törvénykezési székhelyet elutasította, így meghiúsult a választókerületek, a járásbíróságok és a szolgabírói járások területének egybeesése. ${ }^{454}$ Szabolcs vármegyének ezzel szemben azzal a problémával kellett szembesülnie, hogy községeinek jelentős részét a határain kívül eső járásbírósághoz sorolták be, így erre a koncepcióra nem támaszkodhattak. ${ }^{455}$

megkeresö egyén a másik hatóságot lehetóleg közel találja: a megyének szolgabiróságokra felosztásánál a járásbirósági felosztások elfogadását ajánljuk.” - 118. 22592/1871. - Bereg vármegye.

„Sokkal inkább hittünk a csak nem naponta felmerüló életérdekek követelményeinek megfelelhetni, midön elvül megállapitottuk, hogy a közigazgatási szolgabirói járások a törvénykezési járásbiróságok száma és területköre szerint alakittassanak meg." - MNL BM K150 118. 22336/1871. MNL BM K150 118.736/1871. megyei állandó bizottmány közgyűlése. MNL BM K150 117. 17731/1871. „felette óhajtandónak vélem, ha Nagyméltóságod [a belügyminiszter - a szerző] (...) a’szolgabirói kerületeket megállapitó munkálatainkat is az idóközben megváltoztatott járásbirósági székhelyekhöz leendö alkalmazhatása tekintetéböl kiigazitás végett leküldeni méltóztatnék." - MNL BM K150 117. 18194/1871. 
Sáros vármegye szintén azt jelezte a belügyminisztérium számára második tervezetében, hogy a járásbíróságokra tekintettel alakította ki járási beosztását. ${ }^{456}$

A járásbírósági beosztás és az országos választókerületek figyelembevétele helyett az egyes törvényhatóságok más-más területi beosztást is alapnak tekinthettek a területi beosztás kialakításakor. A Nagy-Kikinda kerület az adóhivatalok illetékességi területére helyezte a hangsúlyt beosztásának meghatározásakor. ${ }^{457} \mathrm{Az}$ adóhivatalok a kiegyezést követően is a neoabszolutizmus során kialakított szervezetrendszer alapján működtek. ${ }^{458}$ Trencsén vármegye pedig a neoabszolutizmus („német korszak alatti”) közigazgatási beosztásával azonosan alkotta meg azt. ${ }^{459}$

A leggyakoribb hivatkozási alap a tervezetekben a szolgabírói illetékességi területek kialakítása kapcsán azonban nem a választókerületi vagy a járásbírósági területbeosztás, hanem a vármegye földrajzi fekvése, a közlekedési nehézségek és a különböző természeti akadályok figyelembevétele volt. A topográfiai viszonyok befolyásolták leginkább a legtöbb vármegye járásainak területi meghatározásátt. ${ }^{460} \mathrm{~A}$ közlekedési nehézségekkel magyarázta Csanád, Doboka és Békés, hogy a lakosság számarányához viszonyítva a szükségesnél több járást alakítottak ki ${ }^{461}$ Arad vármegye a belügyminisztérium felhívásának megfelelően olyan módon csökkentette a második tervezetében megjelölt járások számát, hogy a miskei szolgabíróságot megszüntette és az ide tartozó településeket a borosjenői és kisjenői járások között osztotta szét a közlekedési és a helyi viszonyoknak megfelelően. ${ }^{462}$ Aranyosszék olyan kiemelkedő fontosságúnak tartotta a megfelelő közlekedési viszonyok biztosítását, hogy a tervezet belügyminisztériumi felterjesztését követően még a községek meghallgatását kívánta a járási hovatartozásuk ügyében a „kényelmesebb közlekedhetés” biztosítása érdekében. ${ }^{463}$

Több vármegye a megye és a járásaik nagy kiterjedésével és népsürüségével indokolta a járási szervezet kialakítását, amely annak fényében érdekes, hogy Békés vármegye kivételével olyan törvényhatóságok hivatkoztak erre, amelyek az iránymutatóul rendelt 30 ezer fós járásoknál jóval kisebbeket hoztak létre. ${ }^{464}$ Doboka vármegyében befolyásolta a megyerendezést annak tekintetbevétele, hogy a járási tisztviselők munkaterhét nagyban

456 MNL BM K150 117.27062/1871.

SziTa 1980, 387.

MNL BM K150 117. 20171/1871. - Aranyosszék; 21799/1871.; 28287/1871. - Bars vármegye; 21161/1871.. - Békés vármegye; 21068/1871. - Csongrád vármegye; 21272/1871. - Doboka vármegye; 22026/1871. - Felső-Fehér vármegye; 22226/1871 - Krassó vármegye; 20826/1871 - Sáros vármegye; 21797/1871 - Szepes vármegye; 118. 22592/1871. - Bereg vármegye; 23816/1871. - Gömör és KisHont vármegye; 31986/1871. - Hont vármegye; 22326/1871. - Komárom vármegye; 22499/1871. - Kővár vidék; 24696/1871 - Nagy-Kikinda kerület; 28391/1871. - Szabolcs vármegye; 736/1871. megyei állandó bizottmány közgyủlése - Veszprém vármegye; 25636/1871. - Zaránd vármegye. MNL BM K150 117. 17803/1871.; 21272/1871.; 21161/1871.

462

MNL BM K150 117. 21161/1871. - Békés vármegye; 21272/1871. - Doboka vármegye; 118. 31726/1871. - Alsó-Fehér vármegye; 27001/1871. - Bereg vármegye; 23816/1871. - Gömör és KisHont vármegye; 22499/1871. - Kővár vidék. 
növelte a járásukhoz tartozó községek száma, így azon alsó középszintü közigazgatási egységek területét kisebbre szabták, amelyekben sok egymáshoz közel fekvő település helyezkedett el. ${ }^{465}$

Csongrád vármegye, Alsó-Fehér vármegye, Bereg vármegye, valamint Kővár vidék a szolgabírák túlterhelését kívánták elkerülni indoklásuk szerint. ${ }^{466}$ Kővár vidék ennek igazolására a járásokra lebontott előző évi ügyszámkimutatásokat is benyújtotta a belügyminisztériumnak. Ez az indok annak fényében különösen érdekes, hogy a kiegyezést követő államszervezeti reformok a közigazgatási feladatokat számottevően nem szaporították, a törvénykezési hatásköröket pedig leválasztották a szolgabírákról.

Bars, Békés és Komárom vármegyék a régi járási felosztást őrizték meg. ${ }^{467}$ Bars ennek fenntartását azzal magyarázta a belügyminisztérium járások számának csökkentését kívánó leiratára adott válaszában, hogy a kiegyezést követő közigazgatási reformok során a honvédelmi minisztérium által jóváhagyott újoncozási járások és az adóbeosztás területe is ehhez igazodott.

A járási beosztást befolyásoló tényező volt még, hogy a vármegyében található rendezett tanácsú városok az 1870:XLII. tc. és az 1871:XVIII. tc. szerint közvetlenül a vármegyei igazgatás alá tartoztak, így a járási beosztásba ezek a városok nem kerülhettek be. ${ }^{468}$

Az 1870:XLII. tc. megalkotásának célja hiába volt a közigazgatás modern kori elveinek megfelelő reformja, a járások kialakításakor a vármegyei küldöttségek és közgyűlések a tervezetek tanúsága szerint nem tudták azt a legfontosabb követelményt érvényesíteni, hogy biztosítsák az államszervezet egyes feladatait megvalósító helyi szervek illetékességi területeinek egymással való összhangba kerülését, amely nagy mértékben növelhette volna az állam müködésének hatékonyságát. ${ }^{469}$ Emellett érdekes, hogy a belügyminisztérium sem szorgalmazta, hogy a vármegyék a törvény rendelkezéseinek megfelelően járásaikat a választókerületekhez igazítsák. A képet árnyalja, hogy a tervezetek elkészítőinek lehetőségei korlátozottak voltak annak köszönhetően, hogy a vármegyék területének korrekcióját a törvény elfogadásának idején elmulasztotta az országgyuulés ${ }^{470}$ így az egyenlőtlen középszintű területi beosztás miatt igencsak nehézkes volt egységes elvek alapján felépíteni a járási szervezetet. Azonban a járások területét évszázadok óta meghatározó szempontok, így a vármegye földrajzi fekvése, a közlekedési nehézségek és a különböző természeti akadályok is akceptálhatók, különösen, hogy a járásbíróságok szervezésénél is figyelembe kellett venniük ezeket a bírósági szervezet létrehozóinak..$^{471}$

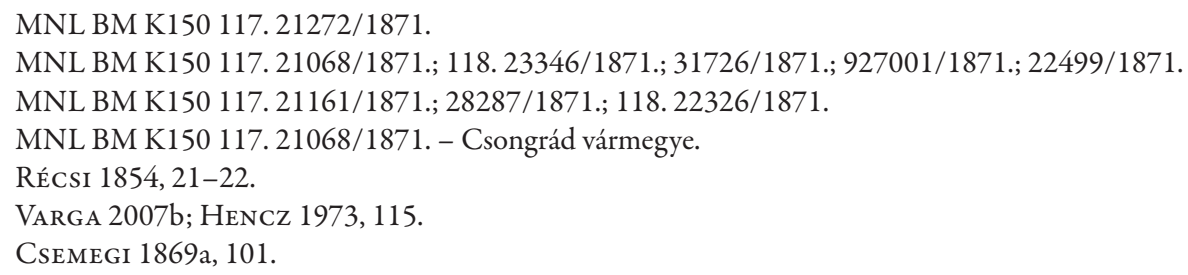




\subsection{A járási szervezet a korábbi területi beosztás és a lakosságszám tükrében}

A vármegyék által kialakított járási rendszert áttekintve megállapítható, hogy az általam vizsgált törvényhatóságok a 12183/1871. számú rendeletben megfogalmazott azon belügyminisztériumi kérésnek kivétel nélkül eleget tettek, miszerint az új szervezet kialakítása során legyenek tekintettel a költségvetési viszonyokra. ${ }^{42} \mathrm{~A}$ húsz törvényhatóság közül ugyanis tizenhárom csökkentette, ${ }^{473}$ míg hét változatlanul hagyta a járásai vagy szakaszai számát a korábbi közigazgatási szervezethez képest. ${ }^{474} \mathrm{~A}$ számításnál azon vármegyéknél, ahol a korábbi szervezeti felépítés a szakaszokat vagy a kerületeket is alkalmazta közigazgatási egységként, nem a járások számát vettem figyelembe, hanem a szolgabírói illetékességi területek mennyiségét. ${ }^{475}$

A törvényhatóságok tehát csökkentették közigazgatási apparátusuk méretét a járások számának mérséklésével. Az már a kiegyezés utáni erdélyi járási beosztás kritikája, hogy Felső-Fehér vármegye hiába hozott létre tíz helyett hat járást, a legnagyobb járása így is csupán 12268 fös lakosságszámmal bírt. ${ }^{476}$ Veszprém vármegye csökkentette a legdrasztikusabban a szolgabírói illetékességi területek számát, mivel az 1871-ben fennálló 17 szakasz helyébe öt járást szervezett. ${ }^{47}$

Az újonnan létrehozott közigazgatási egységek lakosságszámát figyelembe véve megállapítható, hogy a teljesen eltérő szabályozási elveknek köszönhetően különböző méretű járások jöttek létre. A legnépesebb járás a Békés vármegyei csabai és a Veszprém vármegyei pápai, amelyek illetékességi területéhez több mint ötvenezer lakos tartozott. ${ }^{478}$ Ezzel szemben Felső-Fehér vármegye peselneki járásában csupán 5450 fö lakott. ${ }^{479} \mathrm{~A}$ kisméretü erdélyi törvényhatóságokat figyelmen kívül hagyva a legkisebb népességgel bíró járások 10000 fönél valamivel kevesebb lakossal bírtak. Ezekből az adatokból kitünik, hogy a törvényhatóságok közreműködésével egyenlőtlen járási szervezet alakult ki a belügyminisztérium megerősítési joga ellenére is.

A vizsgált törvényhatóságok Bars, Zala, Alsó-Fehér és Pozsony vármegye, valamint Nagy-Kikinda kerület kivételével igyekeztek legalább a területükön belül hasonló lakosság-

472 MNL CSML IV.B. 252.b. 35.d.; MNL BM K150 117. 12183/1871.

473 MNL BM K150 117. 17731/1871.; 17731Sz/1871.; 32702/1871. - Arad vármegye; 21799/1871. - Bars vármegye; 21272/1871. - Doboka vármegye; 17808/1871. - Fejér vármegye; 22026/1871. - Felső-Fehér vármegye; 21800/1871. - Fogaras vidék; 21798/1871. - Zala vármegye; 118. 22592/1871. - Bereg vármegye; 22499/1871. - Kővár vidék; 28726/1871. - Hont vármegye; 25309/1871.; 31404/1871. - Küküllő vármegye; 22336/1871. - Veszprém vármegye; 25636/1871. - Zaránd vármegye.

474 MNL BM K150 117. 20171/1871. - Aranyosszék; 21161/1871. - Békés vármegye; 17803/1871. Csanád vármegye; 21068/1871.; 27282/1871. - Csongrád vármegye; 118.31726/1871. - Alsó-Fehér vármegye; 23816/1871. - Gömör és Kis-Hont vármegye; 22326/1871. - Komárom vármegye.

475 Több vármegye esetében csak valószínüsíthető a szolgabírói illetékességi területek korábbi száma a fö- és alszolgabírók számából, így ezeket figyelmen kívül hagytam.

476 MNL BM K150 117.22026/1871.

477 MNL BM K150 118. 22336/1871.

478 MNL BM K150 117.21161/1871.; 118.22336/1871.

479 MNL BM K150 117.22026/1871. 
számú járásokat létrehozni. ${ }^{480} \mathrm{~A}$ két legkirívóbb ebből a szempontból Bars és Zala vármegye volt, amelyek járásainak népessége nagy szórást mutatott. Bars esetében a legkisebben mindössze 11210 fö lakott, míg a legnagyobban 39611 fö. ${ }^{481}$ Zala vármegyében pedig a kanizsai járás 41503 lakosú volt, míg a baksai mindössze $12421 .^{482}$

Ahogyan korábban már említésre került, a törvény azért szabta a járások meghatározásánál feltételül az országos választókerületek figyelembevételét, mert a jogalkotó ezzel kívánt zsinórmértéket nyújtani a törvényhatóságok számára, hogy milyen lakosságszámú alsó középszintű közigazgatási egységeket határozzanak meg. Ez alapján a törvényhozói szándék harmincezer fö körüli járásokat kívánt. Békés vármegye (a csabai kivételével), Fejér vármegye, Komárom vármegye, valamint Gömör és Kis-Hont vármegye szabta meg járásai területét úgy, hogy valóban harmincezer fő körüli közigazgatási egységek jöjjenek létre. ${ }^{43}$ Veszprém vármegye egy járás kivételével pedig még a harmincezret is meghaladó járásokat hozott létre. ${ }^{484} \mathrm{~A}$ többitől alacsonyabb lakosságszámmal az enyingi járás rendelkezett, amit azzal magyaráztak, hogy az ide csatolható községek Veszprémmel szorosabb kereskedelmi és közlekedési viszonyban álltak, így a települések e járásba való beosztása „csak azért, hogy az enyingi járás népességének száma emeltessék, nyilván az elhelyezésnél döntö körülmények tudva való figyelmen kivül való hagyásának tekintethetett volna." ${ }^{485}$ Nógrád vármegye is Veszprém vármegyéhez hasonlóan járt el, mivel harmincezer fö körüli járásokat hozott létre a füleki kivételével, amely negyvenezer feletti lakosságszámmal rendelkezett. ${ }^{486}$ Nógrád vármegye viszont csupán a belügyminisztériumi felhívást követően szabta meg ilyen kiterjedéssel a járásait.

Fogaras vidék viszont a pontosan húszezer főnyi lakosságszámot tartotta ideálisnak egy-egy járásában ${ }^{487}$ Bereg, Krassó, Szepes, Szabolcs, Trencsén és Arad vármegye egy kiemelkedően népes járást, Doboka vármegye pedig egy kiemelkedően alacsony lakosságszámú járást kivéve szintén húsz-huszonötezer fö körüli alsó középszintű közigazgatási egységeket határozott meg. ${ }^{488}$ Csanád vármegye deklaráltan tizenhat-tizenhétezer fös illetékességi területeket kívánt létrehozni. ${ }^{489}$ Aranyosszék, Felső-Fehér, Hont, Sáros vármegye és Kővár vidék viszont csupán tíz-tizenötezer lakossal hozta létre járásait. ${ }^{490}$

A változékony járási szervezet magyarázata a partikuláris szabályozási mód mellett a törvényhatóságok egyenlőtlen mérete, amely megnehezítette az egységes szervezet

21797/1871.; 28525/1871.

MNL BM K150 117.28287/1871.; 21798/1871. 118. 31726/1871.; 26616/1871.; 24696/1871.

MNL BM K150 117.28287/1871.

MNL BM K150 117.21798/1871.

MNL BM K150 117.21161/1871.; 17808/1871.; 118. 22326/1871.; 23816/1871.

MNL BM K150 118. 22336/1871.

MNL BM K150 118.736/1871. megyei állandó bizottmány közgyủlése.

MNL BM K150 118.22691/1871.

MNL BM K150 117.21800/1871.

MNL BM K150 118. 22592/1871.; 22226/1871.; 32644/1871.; 117. 21272/1871.; 32702/1871.;

489 „A szolgabirónak egy 16-17 ezer lélekböl álló területben elégfoglalkozást is nyújt.” - MNL BM K150 117. $17803 / 1871$.

490 MNL BM K150 117. 20171/1871.; 22026/1871.; 20826/1871.; 118. 28726/1871.; 22499/1871.
} 
létrehozását. Aranyosszék ki is fejtette, hogy az erdélyi törvényhatóságok kicsinységük és szabályozatlanságuk miatt alkalmatlanok a modern közigazgatásra, így a törvényhozástól további területek hozzácsatolását kérte és nem kívánt addig végleges szervezetet létrehozni. ${ }^{491}$

\subsection{A járások elnevezése}

A törvényhatóságok a közigazgatás hatékonysága érdekében évszázadok óta elnevezték járásaikat. A történeti áttekintésből kiderült, hogy a kora-újkor évszázadaiban a hivatalban lévő szolgabíró vagy a tájnevek alapján azonosították ezeket. A közigazgatás fejlődésének következtében fokozatosan elhagyták azt a szokást, hogy a szolgabírák alapján jelöljék meg a járásokat és egyre inkább valamilyen földrajzi jellemző vált a névadóvá.

Az 1870:XLII. tc. alapján a vármegyék által létrehozott járások esetében az elnevezés jellemzően a járásban található nagyobb települések neveihez igazodott. ${ }^{492}$ A névadó azonban nem minden esetben a járás legnagyobb községe volt. Kővár vidék váádi járása kirívó példa erre, mivel Váádnál két jóval nagyobb település is található volt a járásban. A térképre pillantva megállapítható, hogy a település a közigazgatási egység közepén található, így ez indokolhatta ezt. ${ }^{493}$ A Helységnévtárban viszont már az szerepel, hogy 1873-ban a váádi járást monostori járásként nevezték, Monostor lakosságszáma nagyobb volt, mint Váádé, azonban még mindig elmaradt a két legnagyobb település lakosainak számától. ${ }^{494}$

Több vármegye esetében is elöfordul, hogy olyan településről nevezték el a közigazgatási egységet, amely nem volt része a szolgabíró illetékességi területének. Ennek oka az volt, hogy a makói és a nagyenyedi járás esetében is a névadó település rendezett tanácsú város volt. ${ }^{495} \mathrm{Az}$ aradi és a gyulafehérvári járás esetében pedig Arad és Gyulafehérvár törvényhatósági jogú város. ${ }^{496}$

Doboka vármegye az egregy-almási járás esetében tért el a nagyobb településre utaló névadástól, amelynek eredete az lehetett, hogy az alsó középszintű közigazgatási egység nagyobb települései között van Fel-egregy, Magyar-egregy és Hidalmás. A tervezetről készített belügyminisztériumi összefoglaló viszont ettől eltérően magyarszentgyörgyi

${ }^{491}$ „[S]enki elött sem kétséges, hogy Erdélyben különösen a vármegyék, vidékek és szász székek, s névszerint Aranyosszék is nagy részben olyanok, hogy ugy a mint jelenben léteznek, részint idomtalanságuk, részint kicsinységük miatt a törvény és kor kivánalmai által igényelt gyors és pontos közigazgatás céljának meg nem felelhetnek, annak költségeit nem viselhetik." - MNL BM K150 117.20171/1871.

492 MNL BM K150 117. 32702/1871. - Arad vármegye; 21799/1871; 28287/1871. - Bars vármegye; 21161/1871. - Békés vármegye; 17803/1871. - Csanád vármegye; 17808/1871. - Fejér vármegye; 22026/1871. - Felső-Fehér vármegye; 21798/1871. - Zala vármegye 118.31726/1871. - Alsó-Fehér vármegye; 31986/1871. - Hont vármegye; 22499/1871. - Kővár vidék; 22336/1871. - Veszprém vármegye.

493 MNL BM K150 118. 22499/1871.

${ }^{494}$ HeLYSÉGNÉVTÁR 124-125.

495 MNL BM K150 117. 17803/1871. - Csanád vármegye; 118.31726/1871. - Alsó-Fehér vármegye.

496 MNL BM K150 117.32702/1871.; HeLYSÉGNÉVTÁR 78.; 118.31726/1871. 
járásként nevezte meg a közigazgatási egységet, amely település a járáshoz tartozó községek között az első helyen volt megjelölve, viszont csupán a közepes lakosságszámú települések közé tartozott a járásban. ${ }^{497}$ A Helységnévtár adatai szerint azonban valóban az egregy-almási járás elnevezést alkalmazta a vármegye. ${ }^{498}$

Fogaras vidék a törvényi kötelezettség hiánya ellenére kijelölte járásainak székhelyeit, így a járási székhelyek alapján azonosította a szolgabírák illetékességi területeit. Ez alól a bethleni szolgabírói járás jelentett kivételt, mivel ennek székhelye Fogaras törvényhatósági jogú város volt, így ezt az egyik legnagyobb településről nevezték el. ${ }^{499}$ Hont vármegye szintén a székhelyekről nevezte el legtöbbször a járásait. A törvényhatóság esetében azonban a járások neveinél problémát okozott, hogy több alkalommal a székhely nem a járás területén helyezkedett el. Ennek oka a korábbi példáktól eltérően nem az volt, hogy törvényhatósági jogú vagy rendezett tanácsú város volt a székhely, mivel ezek ezer fö alatti települések voltak..$^{500}$

Fejér vármegye tervezetében kiemelte, hogy „a szolgabirói járások az országos választókerületek neveit viselik." 501 Ez egyben azt is jelentette, hogy a járásban elhelyezkedő nagyobb települések a névadók. Ez alól azonban kivételt képezett a bodajki alsó járás, amely esetében Bodajk község nem a járás területén volt található, mivel az a bodajki felső járásban helyezkedett el. Amiatt ragaszkodtak, hogy mégis Bodajkról kapja a nevét a közigazgatási egység, mert így az elnevezés ebben az esetben is az országos választókerülethez igazodott.

Bereg vármegye viszont a járásbíróságok illetékességi területéhez kívánta igazítani a szolgabírói járásait, így a járásbírósági székhelyekről nevezte el azokat. Ez abban a két esetben volt problémás, amikor a törvénykezési illetékességi területet két-két szolgabírói járásra osztották. Ezekben az esetekben a területi egységek a beregszászi I-II. járás és a munkácsi I-II. járás elnevezést kapták. Nyilvánvaló, hogy ezekben az esetekben is egyegy járás olyan településről kapta a nevét, amely nem a területén helyezkedett el. ${ }^{502} \mathrm{Az}$ 1873-ban készült helységnévtárban viszont a két Munkácshoz kötődő járást már nem számmal jelölték, hanem az alapján különböztették meg őket, hogy a Latorca folyó jobb vagy bal partján fekszenek. Emellett pedig a korábban ilosvai járásnak nevezett terület felvidéki néven található meg. ${ }^{503}$

Gömör és Kis-Hont vármegye tervezete az elnevezések tekintetében különös volt, mivel a községek járási beosztását meghatározó tervezet fejlécében szereplő járási elnevezések ötből három esetben is eltérnek az ugyanazon iratban a községek felsorolásánál feltüntetettől. A rosnyói és nagy rőczei járások esetében megegyeztek, viszont a rimaszombati (kishonti), rimaszécsi (serki), tornallyai (putnoki) járásnál nem. ${ }^{504} \mathrm{~A}$ fejléces

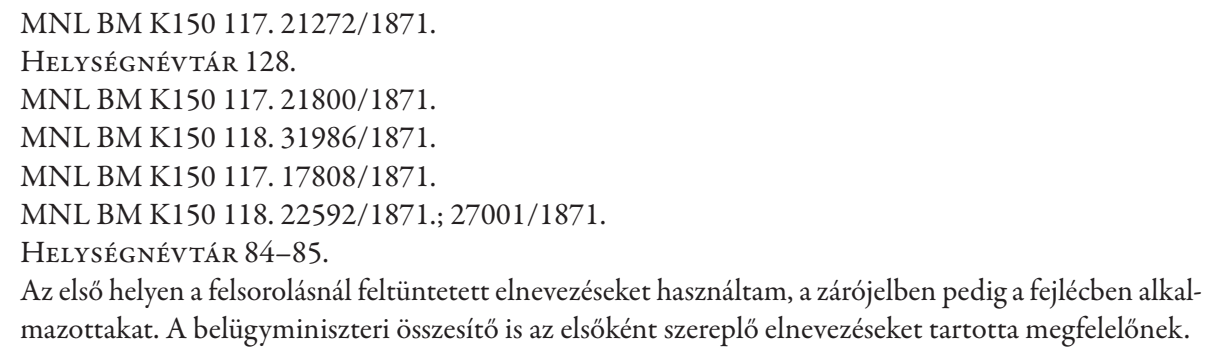


elnevezéseknél a régi járási beosztás elnevezéseit őrizték meg, míg a felsorolásban lévők a járásbírósági székhelyekkel estek egybe, így minden bizonnyal az új járási beosztáshoz hasonlóan az elnevezéseket is a járásbíróságokkal kívánták összhangba hozni. ${ }^{505}$

Bars vármegye a régi járási beosztását tartotta meg, így ennek megfelelően a korábbi elnevezéseket is megőrizte. Az esetükben különös, hogy a kistapolcsányi járás nem a járás legnagyobb településéről és a vármegye székhelyéről, Aranyosmarótról kapta a nevét. ${ }^{506}$

A településnevekhez igazodó névadástól Aranyosszék és Csongrád vármegye, valamint részben Csanád, Szepes és Bars vármegye tért el. Aranyosszék szintén a régi járási elnevezéseket megőrizve alsó és felső járásnak titulálta szolgabírái illetékességi területeit. ${ }^{507}$ Csongrád vármegye viszont a vármegyét kettészelő folyónak köszönhetően a tiszán inneni és a tiszán túli járás elnevezéseket használta. ${ }^{508}$ Bars vármegye garami járása szintén a vármegye legfontosabb folyójának nevét tükrözte. ${ }^{509}$ Szepes vármegye több járását is a területén található folyóról vagy hegységről nevezte el. ${ }^{510}$ Csanád vármegye viszont a makói járás esetében alkalmazta a központi megnevezést is. ${ }^{511}$

Az 1873. március végi állapotokat tükröző Helységnévtár alapján megállapítható, hogy a vizsgált törvényhatóságok a meghatározott elnevezéseket állandó jelleggel alkalmazták. Az egyes alsó középszintü közigazgatási egységek esetében nem ingadoztak az elnevezések, amely elősegítette a központi kormányzat és a vármegyei igazgatás munkáját. Két törvényhatóság esetében tapasztalható eltérés, amit a fentebbiekben ismertettem.

\subsection{A járási székhelyek}

A magyarországi vármegyék esetében az 1723:73. tc., míg Erdélyben az 1791:12. tc. még csupán a közgyưlések, a törvényszékek és a hivatalos levéltár számára kívánt központot létrehozni. ${ }^{512}$ A köztörvényhatóságok rendezéséröl szóló törvény már egyértelmüen törekedett a vármegyék, a székek, a vidékek és a kerületek esetében e kezdeményezés megerösítésére, ugyanis meghatározta, hogy a központi tisztviselők (alispán, jegyzö, tiszti ügyész, árvaszéki elnök és ülnök, pénztárnok, föorvos, fömérnök, levéltárnok, föszámvevő, közgyám, állatorvos) kötelesek a törvényhatóság székhelyén lakni. Ez az intézkedés a korabeli közlekedési viszonyokat figyelembe véve igencsak indokolt volt, mivel a közgyủlésről (törvényhatósági bizottságról) a hangsúly áttevődött a tisztviselőkre a közigazgatási feladatok ellátása során a polgári átalakulásnak köszönhetően.

MNL BM K150 118. 23816/1871.

MNL BM K150 117.21799/1871.; 28287/1871. - Bars vármegye.

MNL BM K150 117.20171/1871.

MNL BM K150 117.27282/1871.

MNL BM K150 117.21799/1871.; 28287/1871.

MNL BM K150 117.21797/1871.

MNL BM K150 117. 17803/1871.

EREKy 1910, 96-98. 
Az általam vizsgált törvényhatóságok közül Gömör és Kis-Hont vármegye foglalkozott ezzel a kérdéssel, mivel elsőszámú feladatuknak tartották a közigazgatási szervezet kialakítása során a megye székhelyének meghatározását. Két várost tartottak alkalmasnak erre: Pelsőczöt és Rimaszombatot. Rimaszombat mellett szólt, hogy az állandó bizottmány képviselöi fejlettebb városnak tartották, mint Pelsőczöt, valamint az igazságügyminisztérium ide helyezte a törvényhatóság egyetlen törvényszékét is. Ennek ellenére a vármegye közönsége Pelsőcz városa mellett döntött, mivel az itteni megyeháza megfelelő lakhatást biztosíthatott a tisztviselök számára, és abban bíztak, hogy a település hamarosan vasúttal is elérhetővé válik. Döntő érvként mégis az szólt Pelsőcz mellett, hogy a törvénykezési szerv Rimaszombatra kerülése miatt úgy kívánták a város számára biztosítani a fejlődési lehetőséget, hogy legalább a vármegye közigazgatási központját itt jelölték ki. ${ }^{513}$ Érdekes, hogy a szolgabírói járásokat a vármegye a járásbíróságokra tekintettel alakította ki, viszont azt nem tartotta fontos szempontnak, hogy a vármegye közigazgatási és törvénykezési székhelye egybeessen, sőt Pelsőcz még járásbírósági székhely sem volt, mivel a rozsnyói királyi járásbíróság illetékességi területéhez tartozott. ${ }^{514}$

A járások esetében viszont a törvény 57 . §-a csupán azt a kötelezettséget rótta a kültisztviselőkre, hogy a járásban (szakaszban) kötelesek lakni. Ezáltal a jogszabály nem kívánta meg a törvényhatóságoktól, hogy meghatározzák a járásaik székhelyét. Megmaradhatott az a vármegyei szokás, hogy a járási ügyintézés a szolgabírák lakhelyéhez kötődött. A tisztikarra vonatkozó szabályokat viszont a törvényhatóságok határozhatták meg, így jogosultak voltak ennél szigorúbb feltételeket szabni a tisztségviselőknek.

Törvényi rendelkezés hiányában Alsó-Fehér vármegye, Arad vármegye, Aranyosszék, Bars vármegye, Csanád vármegye, Zala vármegye, Veszprém vármegye és Kővár vidék végrehajtási tervezeteikben nem foglalkoztak a járási székhely kérdésével. ${ }^{515}$ Ezekben az esetekben ennek ellenére nem lehet kizárni, hogy mégis megállapították a járások székhelyeit, mivel a legtöbb esetben a járások a területükön található nagyobb városokról kapták elnevezésüket, így magától értetődőnek tarthatták, hogy ez a település a járás székhelye is.

Csanád vármegye példáján lehet ezt szemléltetni, amely a szolgabírák járandóságai között természetben teljesítendő lakbért is feltüntetett. Ennek megfelelően a közigazgatás költségei között szerepelt a hivatalos helyiségekben lévő négy szolgabírói lakás fenntartása, tehát eszerint megszabták a szolgabírák lakhelyét, mivel ott lakást biztosítottak a számukra. Emellett a kiadások között elkülönítettek 200 Ft-ot a mezőkovácsházi járás szolgabírója számára a hivatalos helyiségek és a szolgálati lakás bérlésére Mezőkovácsházán. Ebből arra lehet következtetni, hogy a mezőkovácsházi járáshoz hasonlóan a hivatali helyiségek a Csanád vármegyei járások névadó településein helyezkedtek el, így Makón, Nagylakon

513 MNL BM K150 118. 23816/1871. - Gömör és Kis-Hont vármegye.

514 39. A királyi ministerium rendelete 117.

515 MNL BM K150 117. 17731/1871.;17731Sz/1871; 32702/1871. - Arad vármegye; 20171/1871. - Aranyosszék; 21799/1871.; 28287/1871. - Bars vármegye; 17803/1871. - Csanád vármegye; 21798/1871. - Zala vármegye; 118. 23346/1871.; 31726/1871. - Alsó-Fehér vármegye; 22499/1871.

- Kövár vidék; 22336/1871. - Veszprém vármegye. 
és Battonyán, viszont ezeken a településeken nem volt szükség szolgálati lakás bérlésére, mivel a vármegye rendelkezett saját tulajdonú épületekkel. ${ }^{516}$

A járási székhelyekről a tervezetekben kirajzolódó képet érdemes összevetni az Országos Magyar Királyi Statistikai Hivatal által összeállított adatokkal, amelyek az 1873 márciusában fennálló viszonyokat tükrözik. A munkában található egy, a vármegyei közigazgatás területi beosztását tartalmazó rész, amely némely vármegyénél feltüntette a járási székhelyeket is. Minden bizonnyal azonban az adatszolgáltatás során nem irányult ezek ismertetésére is az adatgyüjtő konkrét kérése. Ezt bizonyítja, hogy míg a belügyminisztériumnak felterjesztett tervezeteikben Békés vármegye és Fogaras vidék meghatározták járásaik központjait, ${ }^{517}$ addig $A$ Magyar Korona országainak helységnévtárában már nincsenek feltüntetve ezek a székhelyek. ${ }^{518}$ Kicsi a valószínűsége, hogy az 1872. január 1-jével müködésbe lépő közigazgatási szervezeteikből 1873 márciusára kiiktatták volna a járási székhelyeiket, így inkább adatszolgáltatási hibáról lehet szó. A fentiekben már ismertettem, hogy Arad vármegye nem foglalkozott a tervezetében a járási székhelyek kérdésével; a statisztikai összefoglaló munka szerint ennek oka valóban az, hogy nem határozta meg a központjait. ${ }^{519}$ Ezzel szemben Alsó-Fehér, Bars, Veszprém, Zala vármegyében és Aranyosszéken 1873 márciusában már voltak kijelölt járási székhelyek annak ellenére, hogy a tervezeteikben nem tüntettek fel ilyeneket. ${ }^{520} \mathrm{~A}$ vármegyék esetében azonban több megjelölt székhely a járás kisebb települései közül került ki, így valószínünek mutatkozik, hogy az adatszolgáltatás során a szolgabírák lakhelyét jelölték meg járási székhelyként.

Fejér, Doboka, Bereg, valamint Gömör és Kis-Hont vármegyék azonban kifejezetten úgy határoztak, ${ }^{521}$ hogy nem szabják meg szolgabíráiknak, mely településeken kell lakniuk vagy hivatali helyiséget fenntartaniuk. Doboka vármegye emiatt a szolgabírákat arra kötelezte, hogy szükség esetén a lakhelyétől távol eső települések lakói számára a közigazgatási ügyeik elintézése céljából egy közelebbi településen is biztosítson meghatározott időközönként ügyfélfogadást. ${ }^{52}$ Fejér vármegye pedig feltételként szabta, hogy a szolgabíró lakhelye a járás középpontjától távol nem eshet. ${ }^{523}$ Bereg vármegye a törvény rendelkezéseivel összhangban a szolgabírák számára csak azt tette kötelezővé, hogy a járásuk területén lakjanak. ${ }^{524} \mathrm{Az}$ 1873. évben megjelent helységnévtárban viszont már feltüntették Fejér vármegyének, Doboka vármegyének és részben Bereg vármegyének is a

\footnotetext{
516 MNL BM K150 117. 17803/1871.

517 MNL BM K150 117.21161/1871. - Békés vármegye; MNL BM K150 117.21800/1871. - Fogaras vidék.

518 HELYSÉGNÉVTÁR 83.; 134.

519 HelysÉGNÉVTÁR 78-79.; 82-83.

520 HELYSÉGNÉVTÁR 117-118.; 119-121.; 126-127.; 135.

521 MNL BM K150 117. 17808/1871.; 21272/1871.; 118. 22592/1871.; 32032/1871.

522 „A szolgabiró székbelyének az 1870. 42. t. rendelete szerént a járásban kelletvén lennie, ha ez esetleg a járás szélében lenne, havonként, vagy két hetenként felváltva még egy más helyen is, mely a székhelyétól távolesó községeknek közelebbi elérhetés tekintetének megfeleljen, tartand közigazgatási ügyekben hivatalos össze jöveteleket." - MNL BM K150 117.21272/1871.

523 MNL BM K150 117. 17808/1871.

524 MNL BM K150 118. 22592/1871.
} 
járási székhelyeit. ${ }^{525}$ Kérdésként merül fel azonban, hogy ezek a vármegyei közgyűlés vagy később a törvényhatósági bizottság által meghatározott települések, vagy a régi szokásnak megfelelően a hivatalban lévő szolgabírák lakhelyei. Fejér vármegye esetében az ekképpen megjelölt községek, ha nem is minden esetben a járás legnagyobb népességü települései voltak, de a nagyobb lakosságszámúak közül kerültek ki. Bereg vármegyében azonban a három járásnál feltüntetett járási székhelyből két település ilyen módon való megjelölése a lakosságszám alapján indokolatlannak tűnik. Doboka vármegyében pedig hat járásból háromban is kifejezetten kis lakosságszámú volt a járási székhely, különösen Kecsed-Szilvás, amelynek mindössze 296 lakosa volt, és ezek elhelyezkedése sem indokolta kitüntetett szerepüket. Ez alapján e vármegyék inkább a szolgabírák lakhelyeit szerepeltethették a vármegye járási székhelyeiként. Bereg vármegye esetében ezt megerősíti, hogy 1878-ban is a szolgabíró lakhelyéhez igazodó székhelyek voltak járásaikban. ${ }^{526}$

Felső-Fehér vármegye szintén úgy rendelkezett a szolgabírói hatáskör meghatározásánál, hogy elegendő, ha a szolgabíró a járásában lakik, viszont lehetőség szerint a központban hivatalos irodáról és fogdáról kell gondoskodnia. A járási beosztásról szóló tervezetben nem tüntették fel az egyes járások székhelyeit, így az feltételezhető, hogy a járás névadó településeit tarthatták a központoknak. ${ }^{527}$ Ezt a feltételezést részben igazolja a vármegye járásairól 1873-ban készített összeállítás, mivel a hat járás közül négyben igazodik a járás székhelye a névadó településhez. ${ }^{528}$

Hont vármegye az általa készített első járási beosztás indoklásában kifejtette álláspontját a szolgabírói székhely kérdéséről: a szolgabírák feladatköre nem helyhez kötött, így inkább előnyös, ha a régi szokásoknak megfelelően a szolgabíró keresi fel a járásához tartozó településeket. Véleményük szerint alkalmasabb egyének lesznek megnyerhetőek, ha nincs megszabva a szolgabírák számára, mely településen kötelesek lakni. ${ }^{529} \mathrm{~A}$ vármegye közönsége azonban a belügyminisztérium felhívására az egységesítés érdekében a tervezet átdolgozására kényszerült, amelyben már a korábbi részletes járási székhely elleni érveléssel szembehelyezkedve meghatározta a járási székhelyeket. ${ }^{530}$ Kérdéseket vet fel azonban, hogy a bozóki és a balogi járás esetében olyan településeket határozott meg központként, amelyek nem az adott járás területén találhatóak. A bozóki járás székhelye a lukanényei járásban található Lukanénye, míg a balogi járásnak a szintén a lukanényei járásban elhelyezkedő Ujfalu. Ha a járási székhely Hont vármegyében a szolgabíró lakhelyét is jelentette, mint a legtöbb vármegye esetében, akkor a vármegye megszegte a törvény

525 HeLYSÉGNÉVTÁR 81-82.; 128-129.; 84-85. (A gyűjteményes műnek ezt a részét tévesen számozták, így a 81 és 88 közötti oldalszámok kétszer szerepelnek.)

526

FÁBIÁN-MEZÖ-KovaCsICS 2000, 48.

527

528

529

MNL BM K150 117.22026/1871.

HELYSÉGNÉVTÁR 129.

"[A] szolgabirói székhelyeket illetöleg még: hogy tekintetbe véve a régi megyék szokását, midön inkább a szolgabiró kereste fel a népet falujában, mint ez a szolgabirót „bureau” - jában, de azon körülményt is, hogy ha a szolgabiró nem lesz kötve bizonyos helyhez kisebb fizetéssel is fognak értelmes és vagyonosabb egyének megyei szolgálatra vállalkozni, a szolgabirákat, a közérdek szempontjából is inkább mozgositani óhajtolag, bárbol, akár kerületük, akár illetö járásuk területén lakhatóknak határozta." - MNL BM K150 118. 28726/1871.

530 MNL BM K150 118.31986/1871.; HELYSÉGNÉVTÁR 86-87. 
erre vonatkozó szabályozását. Az 1873-ban kiadott Helységnévtárban feltüntetett adatok megegyeznek ezzel, így kijelenthető, hogy nem csupán elírásról van szó. ${ }^{531}$

Számos vármegye Honthoz hasonlóan megállapította járásainak székhelyét. Csongrád vármegye egyenesen ragaszkodott ehhez, ugyanis már a járási beosztásról rendelkező első tervezetében a négy szolgabírói illetékességi területnek kijelölte a központját, ám ezt a felterjesztést a minisztérium nem erősítette meg, hanem kérte a járások számának csökkentését. ${ }^{532} \mathrm{~A}$ vármegye közönsége az új tervezetében két járásra osztotta fel a vármegye területét, és az átformált területi beosztást követően is meghatározta az alsó középszintű közigazgatási egységek székhelyeit. ${ }^{533}$ Békés és Pozsony vármegye a szolgabírói járások székhelyét a királyi járásbíróságok számára kijelölt városokkal megegyezően jelölte ki. ${ }^{534}$ Nagy-Kikinda kerület a tervezet indoklásában még a járási székhelyek kiválasztását is megindokolta. ${ }^{53}$ Fogaras vidék úgy határozta meg a szolgabírói járásainak székhelyét, hogy hangsúlyozta a vidék bizottságát illeti a megváltoztatásukra irányuló jogosultság. ${ }^{536}$ Trencsén és Krassó vármegye pedig egyszerủen kötelezővé tette a szolgabírák számára, hogy a székhelyen lakjanak. ${ }^{537}$

A járásaik székhelyeit megállapító vármegyék esetében megvizsgálható az is, hogy milyen szabályszerűség alapján határozták meg az alsó középszintű közigazgatási egység központját. Békés vármegye a járás névadó, legnagyobb lakosságszámmal bíró településeit tette meg járásai székhelyéül. ${ }^{58}$ Fogaras vidék négy járásából kettőben szintén a nagyobbnak mondható települések közül választotta ki a járás székhelyét. A törcsvári szolgabírói járásban viszont a mindössze 110 lakossal bíró Törcsvár lett a központ, pedig kétezer fö körüli települések is találhatók voltak a járásban. A bethleni szolgabírói járás esetében pedig Fogaras városa lett a székhely, annak ellenére, hogy a település szabad királyi városként nem is tartozott a szolgabíró illetékességi körébe, így nem tartozott a járáshoz sem. ${ }^{539}$

A járási székhelyek kapcsán a fenti adatok tükrében leszögezhető, hogy a legtöbb vármegye konkrét központ meghatározására a törvény által kínált lehetőségnek megfelelöen nem törekedett. A vizsgált törvényhatóságok több mint negyede azonban vagy a székhelyek meghatározásával, vagy esetleg más megoldással (Fejér, Doboka, Felső-Fehér) igyekezett túllépni azon a rendi korból származó szokáson, hogy a járási székhely és a járási ügyek intézésének a terepe a szolgabíró lakhelyéhez igazodik. Ennek megfelelően túlzónak tünik Ereky István azon általános megállapítása, hogy a köztörvényhatósági törvény hatályba lépését követően is a székhely folyton, „majdnem minden tisztújításkor változott." 540

\footnotetext{
531 HeLYsÉgNÉvtÁr 86-87.

532 MNL BM K150 117.21068/1871. 


\subsection{A törvényhatósági jogú és a rendezett tanácsú városok kapcsolata az alsó középszintű területi beosztással}

Az 1870:XLII. tc. 1. §-a értelmében az országgyűlés a szabad királyi városokat törvényhatóságokká nyilvánította. Ezen túl a vegyes és átmeneti intézkedések között felsorolt mintegy húsz település is törvényhatósággá alakult. A törvényhatósági joggal bíró városok önkormányzati jogosultságaikat a vármegyei törvényhatóságoktól függetlenül gyakorolhatták, így közigazgatási területeik is elváltak a vármegyéktől. A vármegyék a járási beosztásokat meghatározó tervezeteikből így a törvény rendelkezéseinek megfelelően kihagyták azokat a városokat, amelyek önálló városi törvényhatósággá alakultak. ${ }^{541}$

A rendezett tanácsú városok helyzete már nem volt ennyire körülhatárolt. A törvényhatósági jogú városokhoz képest kevésbé volt egyértelmű, hogy mely települések tartoznak a rendezett tanácsú városok közé. A nagyközségek rendezett tanácsú várossá való átalakulásáról a döntést a községi törvény a belügyminisztérium hatáskörébe utalta. A községek átalakulásáig pedig a törvény elfogadásakor, tehát még nem az újonnan létrejövő törvénykezési beosztás értelmében, az első folyamodású bírósági hatósággal rendelkező mezővárosokat nyilvánította az 1871:XVIII. tc. 140. §-a rendezett tanácsú városokká. ${ }^{52}$ Ennek következtében 1871 júniusát követően lehetősége volt a jogszabály által támasztott feltételeknek megfelelő településeknek a rendezett tanácsú várossá alakulást kezdeményezni.

A rendezett tanácsú városok közigazgatási helyzetéről rendelkezett az 1870:XLII. tc. 12. \$-a, amelynek értelmében: „Azon törvényhatóságokban, a melyekben rendezett tanácsu városok vannak, a törvényhatóság egyetemét közösen illető költségek a járásiaktól elkülönitve állapittatnak meg és vettetnek ki. A rendezett tanácsu városok csak a közös költségekhez járulnak." A községekről szóló 1871:XVIII. tc. 33. §-a pedig a következőket fogalmazta meg: „A rendezett tanácsu városok, közvetlenül és kizárólag az alispán, kis és nagy községek a járási (szakasz) tisztviselőség utján veszik a törvényhatóság rendeleteit, s ezekre vonatkozólag a törvényhatósággal, ezen hatósági közegek utján, érintkeznek.” E törvényi rendelkezések alapján a rendezett tanácsú városok nem tartoztak a szolgabírák joghatósága alá, így a járási szervezettől is külön kezelendők voltak. ${ }^{543}$

Ennek fényében egy-egy vármegye közigazgatási beosztását igencsak meghatározta, ha rendezett tanácsú város volt található a területén. A járások kialakítása szempontjából emiatt fontos kérdés volt, hogy mely településeket tekintettek rendezett tanácsú városoknak. A közigazgatási járások számának és székhelyeinek meghatározásáról szóló 537. számú törvényjavaslat, az ún. Szapáry-féle javaslat tartalmazott egy összeállítást az 1873.

\footnotetext{
541 MNL BM K150 117. 32702/1871.; HelysÉgNÉvtár 78. - Arad vármegye; 21799/1871. - Bars vármegye; 21068/1871. - Csongrád vármegye; 21272/1871. - Doboka vármegye; 17808/1871. - Fejér vármegye; 21800/1871. - Fogaras vidék; 118. 23346/1871. - Alsó-Fehér vármegye; 28726/1871. Hont vármegye.

542 VÉGHeLY 1886, 4.

543 KI 1869. V.k. 197.
} 
december 1-jén rendezett tanácsú városi jogállással rendelkező településekről. ${ }^{544}$ Ebben a törvényjavaslatot elkészítő belügyminisztérium 72 rendezett tanácsú várost sorolt fel. A járások kapcsán a jelen munka szempontjából igazán releváns időszak azonban az 1871. év második fele, mivel ekkor készültek el a vármegyei tervezetek, így azt szükséges megállapítani, hogy melyek voltak ekkor a rendezett tanácsú városi rangú települések. Tóth Vilmos belügyminiszter 1872. november 27-én a Képviselőházban egy interpellációra válaszolva akképp nyilatkozott, hogy összesen hét nagyközség alakult át rendezett tanácsú várossá és 17 rendezett tanácsú város alakult nagyközséggé a községi törvény hatályba lépése óta. ${ }^{54}$ Ebből az következik, hogy a Szapáry-féle javaslatban feltüntetett rendezett tanácsú városok jelentős része már a köztörvényhatósági törvény végrehajtása alkalmával rendezett tanácsúnak minősült, mivel a belügyminisztériumi jóváhagyásra csupán hét településnek volt szüksége. Ezt a megállapítást igazolják az általam vizsgált rendezett tanácsú városok is, amelyekről az alábbiakban lesz szó.

Hajdú kerület közigazgatási szervezetének létrehozása során a törvény rendelkezéseinek megfelelően mellőzte a járások kialakítását. A kerület ugyanis rendezett tanácsú városokból állt össze, amelyek önállóan intézték közigazgatási teendőiket, így szükségtelen volt a kerületben a járási szervezet kiépítése és a szolgabírói tisztség létrehozatala. ${ }^{546} \mathrm{~A}$ belügyminisztérium a Hajdú kerület indoklását tudomásul véve megerősítette a törvényhatóság álláspontját. Ennek megfelelően a Szapáry-féle törvényjavaslat indoklásában hat rendezett tanácsú várost (Böszörmény, Dorogh, Hadház, Nánás, Vámospércs, Szoboszló) soroltak fel a Hajdú kerület részeként.

Alsó-Fehér vármegye, Aranyosszék, Csongrád vármegye és Csanád vármegye a Hajdú kerülethez hasonlóan a rendezett tanácsú városokat nem sorolta be a járási szervezetbe, hanem a törvényhatóság fennhatósága alá tartozó önálló közigazgatási egységként kezelte őket. ${ }^{547}$ Makót, Felvincet és Szentest már rendezett tanácsú városként tüntették fel a tervezetek, Csongrád vármegye Hódmezővásárhelyt és Csongrádot pedig várhatóan rendezett tanácsú várossá alakuló településként hagyta meg a törvényhatóság közvetlen fennhatósága alatt. ${ }^{548}$ Alsó-Fehér ezzel szemben Nagyenyedet nemesi városként helyezte közvetlen törvényhatósági fennhatóság alá. Az 1873. márciusi állapotokat tükröző Helységnévtár a Csanád vármegyéhez tartozó Makót, valamint a Csongrád vármegyéhez tartozó Szentest és Csongrádot viszont egy-egy járás részeként tüntette fel, ${ }^{549} \mathrm{de}$ ez minden bizonnyal téves adatokon alapul, mivel a Szapáry-féle javaslat is a rendezett tanácsú városok közé sorolta ezeket.$$
\text { Az } 1870 \text { XLII t.cz. } 915 \text { a }
$$
tanácscsal biró községek, melyek saját föhadnagyaik vezetése alatt közigazgatásilag önálló helyhatóságaik által kormányoztatnak, miután a törvényhozás ezeknek jogkörét meghagyta és megerösitette." - MNL BM K150 118. 23336/1871.; HeLYSÉGNÉVtÁr 125.

547 MNL BM K150 117. 20171/1871. - Aranyosszék; 17803/1871. - Csanád vármegye; 21068/1871. - Csongrád vármegye; 118.31726/1871. - Alsó-Fehér vármegye.

548 „Hódmezö-Vásárhely szinte bir oly szervezetü tanácscsal és képviselö testülettel, mint a rendezett tanácsú városokê" - MNL BM K150 117.27282/1871. - Csongrád vármegye.

549 HeLYSÉGNÉvtÁR 80-81. 
Nagyenyed, Makó és Szentes már a községi törvény elfogadásakor rendezett tanácsú városként működött, így nem volt szüksége a belügyminisztérium jóváhagyására. ${ }^{550} \mathrm{Az}$ Aranyosszéken található Felvinc a belügyminisztérium engedélyét 1872. október 16-án kapta meg. ${ }^{551}$ Hódmezővásárhely helyzete pedig valóban hamarosan rendeződött, mivel az 1873:XI. tc. törvényhatósági joggal ruházta fel.

Több vármegye viszont éppen ellenkezően járt el, mivel Beregszász, Rozsnyó és Nagykanizsa már 1871-ben is rendezett tanácsú városnak minősültt, ${ }^{552}$ ennek ellenére Bereg vármegye, Gömör és Kis-Hont vármegye és Zala vármegye beosztotta a járási szervezetébe a településeket. ${ }^{553} \mathrm{~A}$ városok a községi törvényt megelözően az 1848:XXIV. tc. rendelkezéseiből származtathatták e státuszukat.

Léva, Munkács, Dobsina, Jolsva és Veszprém viszont csak a közigazgatási tervezetek elfogadását követően alakult a belügyminisztérium engedélyével nagyközségből rendezett tanácsú várossá. ${ }^{554} \mathrm{~A}$ rendezett tanácsú várossá alakulás azonban nem volt minden esetben zökkenőmentes folyamat. Veszprém számára hiába engedélyezte már 1872 júliusában a belügyminisztérium a város rendezett tanácsúvá alakulását,, ${ }^{555}$ a település közigazgatási szervezetének létrehozása közben felmerült problémák miatt csupán 1875-ben tudták összehívni a képviselö-testületet, így csupán ekkor vált Veszprém városa „rendezett tanácsúvá”, 556 így a Szapáry-féle javaslatban „még nem szervezkedett”-ként tüntették fel. Természetesen ezeket a városokat is beosztották a felállítandó járásaikba a vármegyék. ${ }^{557}$

A rendezett tanácsú városok és a járások viszonya tehát igen zavaros volt, amelyet a belügyminiszteri tanácsosok a megerösítés során sem kíséreltek meg korrigálni. Ezt igazolja, hogy egyik törvényhatóság esetében sem emeltek kifogást a rendezett tanácsú városok hovatartozása kapcsán. Az egyes települések rendezett tanácsú városi státuszának a községi törvény alapján való elfogadtatása egybeesett a vármegyék járási beosztásának meghatározásával, amely nagymértékben nehezítette az egyes törvényhatóságok tervezeteinek kidolgozását. Minden bizonnyal ez okozta azt, hogy a belügyminisztériumi tanácsosok a megerősítés alkalmával a rendezett tanácsú városok és a járások kapcsolatának egységes rendezésére nem fektettek hangsúlyt.

\footnotetext{
550 KI 1872. XI. k. 60.; Helységnévtár 126-127. - Nagyenyed; Kelemen 1970, 23. - Makó.

551 BK 1872/241. 1930.; HELYSÉGNÉVTÁR 135.

552 BK 1870/3. 53. - Beregszász; BK 1867/174. 1999., Komoróczy 1903, 128. - Rozsnyó; Foki 2011, 13-14. - Nagykanizsa.

553 MNL BM K150 118. 22592/1871.; 23816/1871.; 21798/1871.

554 FÉJA 1939, 338.; LEHoczKy 1907, 111.; BK 1873/63.529. - Munkács; BK 1872/239. 1917. - Dobsina; BK 1872/160. 1276. - Jolsva

555 BK 1872/121.963.

556 VÉGHELY 1886, 5-13.

557 MNL BM K150 117.21799/1871., 28287/1871. - Bars vármegye; 118. 22592/1871. - Bereg vármegye; 23816/1871. - Gömör és Kis-Hont vármegye, 22336/1871. - Veszprém vármegye.
} 


\section{A SZOLGABÍRÓI HIVATAL FELÉPÍTÉSE}

A köztörvényhatóságokról szóló törvény értelmében a szolgabíró a járás első tisztviselője volt. A bemutatott járási beosztás a tisztviselő feladatait ellátó szolgabírói hivatal illetékességi területeként szolgált. Az 1870:XLII. tc. 61. § értelmében a járások élén a szolgabírák álltak, akik felett az alispánnak volt utasítási jogköre. E tisztviselők munkáját a nekik felelös szolgabírói írnokok segítették, akik kinevezésére és elbocsátására a törvény 65. §-a szerint a szolgabíró volt jogosult. A törvényhatósági tisztviselők megválasztása a törvényhatósági bizottság hatáskörébe tartozott, míg a levéltárnok, valamint a segéd- és kezelőszemélyzet tagjainak kinevezése a főispánt illette, a szolgabírói írnok kivételével. ${ }^{558}$ Ebből látható, hogy ez a rendelkezés különleges jogkört biztosított számára, mivel a szolgabírón kívül más vármegyei tisztségviselő nem rendelkezett azzal a jogosultsággal, hogy maga nevezhesse ki legközelebbi munkatársait. A járás élén álló tisztviselő a járási közgyám, a járási orvos és a járási számvevő irányában nem rendelkezett utasítási joggal, azok ugyanis a központi tisztségviselőjüknek, így a föorvosnak, a főszámvevőnek és a közgyámnak segítették a munkáját. ${ }^{559}$ Ennek ellenére a járási feladatok ellátása során a szolgabíró együttműködött a többi járási tisztviselővel, vagy a vármegye akár bizonyos hatáskörök esetén utasítási jogot adhatott a szolgabíró számára is. ${ }^{560}$

A szolgabírói hivatalok létrehozása a törvényhatóságok feladata volt, mivel az 1870:XLII. tc. 91. §-ának c) pontja szerint a vármegyei tisztikar, a segéd-, a kezelő- és a szolgaszemélyzet megállapítása a szervezési előmunkálatok körébe tartozott. E fejezetben így az erre vonatkozó törvényi rendelkezések bemutatását követően, azoknak a vármegyékben történő végrehajtását vizsgálom.

\subsection{Az átalakításra váró járási szervezet}

A kormányzat a kiegyezést követően az 1848 előtti tisztikar visszaállításáról rendelkezett. A vármegyék járási szervezete így a rendi hagyományoknak megfelelően partikuláris képet mutatott az 1870:XLII. tc. végrehajtását megelőzően. A korabeli szakirodalmi munkák szerint az alsó középszintű közigazgatási feladatokat a vármegyék többségében a választott fó- és alszolgabírák végezték, akiknek munkáját esküdtek segítették. ${ }^{561} \mathrm{~A}$ rendi hagyományoknak megfelelően a főszolgabíró kerülete mellett a teljes járásért is felelős volt, míg az alszolgabírák a föszolgabíró ellenőrzése mellett a kerületüket igazgatták. ${ }^{562}$

\footnotetext{
558 VARGa 2006, 607.

559 MNL BM K150 118. 22592/1871. - Bereg vármegye.

560 A járási orvos „általában minden orvosrendôri teendöt a megyei fóorvos, vagy a járásbeli szolgabiró felhivására végezni köteles." - MNL BM K150 118.22336/1871. - Veszprém vármegye.

561 RÉCSI 1861, 482.; BEÖTHY 1846, 111-112.

562 Puky 1828, 56-62.
} 
A belügyminisztériumnak felterjesztett legtöbb vármegyei tervezet tartalmazta az 1871. évi vármegyei tisztikar szervezetét is, amelyek igazolják a fentiekben vázoltakat. A vármegyék járásaik élére a föszolgabírákat helyezték, a járásokban szervezett közigazgatási egységek adminisztratív feladatait pedig ugyanezen föszolgabírák és változó számú alszolgabíró végezte. A fö- és alszolgabírák mellé esküdteket rendeltek. ${ }^{563}$ Sáros, Doboka és Csanád vármegye a fó- és alszolgabírái mellett viszont esküdteket nem tüntetett fel a régi közigazgatási szervezetében. ${ }^{564}$ Felső-Fehér és Küküllő vármegye, valamint Fogaras vidék szintén nem alkalmazott sem esküdtet, sem szolgabírói írnokot csupán szolgabírót és segédszolgabírót, vagy szolgabírói segédet. ${ }^{565}$ Aranyosszék, Békés vármegye és Kővár vidék járási hivatalaiból viszont az alszolgabírák hiányoztak és a szolgabíró vagy főszolgabíró mellett csupán esküdteket alkalmaztak. ${ }^{566}$ Számos vármegye az irodai teendők ellátása érdekében a szolgabírák, alszolgabírák mellé rendelve írnokot vagy díjnokot is foglalkoztatott, de ezen esetekben nem igazán figyelhető meg szabályszerűség. ${ }^{567}$ Ezek a törvényhatóságok sem állítottak minden járási feladatot ellátó tisztviselő mellé írnokot. A többitől jelentősen a Nagy-Kikinda kerület tért el, ugyanis a szolgabírói teendőket a kerületi tanácsnokok végezték e közigazgatási egység területén. ${ }^{568}$

\subsection{A járás élén álló szolgabíró}

A köztörvényhatósági törvény 61 . \-ának értelmében a járások vezetését a szolgabírák látták el. A belügyminiszteri tanácsos Szabolcs vármegye tervezetére adott leiratában ezt a következőképpen határozta meg: „Minden egyes járás élére egy önálló s egyenlő hatáskörrel fölrubázott szolgabiró állitandó." ${ }^{699} \mathrm{~A}$ járások élén álló tisztségviselőknek rangjuk és munkakörük is azonos volt. ${ }^{570}$

A szolgabírák járások élére állításával kapcsolatban merült fel az a probléma, hogy több vármegye is a főszolgabírói titulust kívánta a törvény végrehajtása előtti szervezetének

MNL BM K150 117. 17731/1871. - Arad vármegye; 21799/1871. - Bars vármegye; 21068/1871. Csongrád vármegye; 17808/1871. - Fejér vármegye; 22226/1871. - Krassó vármegye; 21797/1871. Szepes vármegye; 20991/1871. - Trencsén vármegye; 21798/1871. - Zala vármegye; 118. 22592/1871. - Bereg vármegye; 23816/1871. - Gömör és Kis-Hont vármegye; 28726/1871. - Hont vármegye; 22326/1871. - Komárom vármegye; 22691/1871. - Nógrád vármegye; 26616/1871. - Pozsony vármegye; 28391/1871. - Szabolcs vármegye; 22336/1871. - Veszprém vármegye; 25636/1871. - Zaránd vármegye.

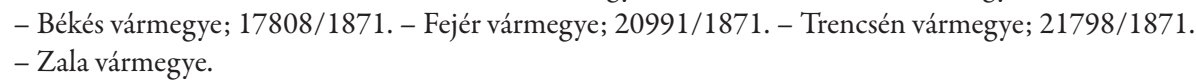


megfelelően megőrizni. Bars, Sáros, Gömör és Kis-Hont, Komárom, valamint Veszprém vármegyék jártak el ilyen módon. ${ }^{571}$ Sáros vármegye azért tervezte a főszolgabírói cím megtartását a vármegyei tisztikarában, mert a közgyülés a kerületek élén álló tisztviselők között különbséget akart tenni, ${ }^{572}$ és a hadüggyel kapcsolatos járási hatáskörök közül az újoncozási teendőket az alszolgabíráktól elvonva csupán a föszolgabírákhoz kívánták utalni. ${ }^{573}$ Emellett a járás képviseletét is a fószolgabíró látta volna el, valamint fenntartották volna azt a szokást, hogy megválasztásakor a főszolgabíró jogosult a járáshoz tartozó két kerület közül megválasztani az illetékességi területét. Bars vármegye a fószolgabírót azért kívánta a járás élére állítani, hogy ezáltal az alszolgabírák munkájának az irányítását a kezébe adja. ${ }^{574}$ Komárom vármegye a hagyományokra hivatkozva őrizte volna meg a föszolgabírákat közigazgatási szervezetében, valamint a fö- és alszolgabírák hatásköreit is jelentősen elkülönítették volna. ${ }^{575}$ A föszolgabírák lettek volna tervezetük szerint a járás vezetői, akik alárendeltségében végezhetik munkájukat az alszolgabírák. Mind az öt vármegye első tervezetében az alszolgabírói tisztséget is létrehozta, így szükség volt a főszolgabírói titulus megtartására a két járási tisztviselő megkülönböztetése céljából.

A belügyminisztériumi tanácsosok azonban megtagadták a korábbi tisztségnevek megerősítését, arra hivatkozva, hogy a törvény szövege csupán az ott megjelölt tisztségneveket engedélyezi, így a rendi kor főszolgabíróit tervezetükben váltsák fel az azonos elnevezéssel és hatáskörrel bíró szolgabírákra. A Sáros, valamint Gömör és Kis-Hont vármegyéknek küldött minisztériumi leiratok indoklása e kérdés megítélésében pontosan megegyezett. ${ }^{576}$

Sáros és Bars vármegye a belügyminisztériumnak küldött válaszában elfogadta a fószolgabírói elnevezés elhagyását a közigazgatási szervezetének tervezetéből. Bars vármegye a következő szavakkal ismerte el, hogy a belügyminisztérium a törvénynek megfelelően kérte az elnevezés korrekcióját: „A törvényszabta szolgabirói elnevezés visszaállitatott 's úgy az ö valamint segédének hatásköre, a szolgabiró felelösségének, a biróságok és községek

571 MNL BM K150 117.21799/1871.; 20826/1871.; MNL BM K150 118. 23816/1871.; 22326/1871.; $22336 / 1871$.

572 Sáros vármegye első tervezetében nem járásokat szervezett, hanem kerületeket, amely megoldás módosítására a belügyminisztériumi tanácsosok szintén felszólították a vármegye közönségét.

573 „Az ekként alakitott 12 kerület mindegyike egy egy egyenlö hatáskörrel ellátott szolgabirónak hatósága alá helyeztetik. A 2 kerületi szolgabiróból az egyik fószolgabiró lesz és ö végzi a teljes járásban az újoncozási teendöket." - MNL BM K150 117.20826/1871.

574 „A járási tisztviselök hatáskörére vonatkozó utasitás 1.5 a) szerint a járási közigazgatási elsö tisztviselönek föszolgabiro czim adatik, sjogában álland: járása területét az alszolgabirák között beosztani." - MNL BM K150 21799/1871.

575 MNL BM K150 118. 22326/1871.

576 „A javaslatba kapottfó és alszolgabirói állomások szervezését illetöleg pedigfigyelmeztetem a megye közönségét hogy miután a föszolgabirói állomás szervezése a törvényhozás által szándékosan mellöztetett, s a törvény járási tisztviselöknél csak szolgabirát és irnokot jelöl ki, a foszolgabirói állomásokat mint a törvénynyel ellenkezőket helyben nem hagyhatom." - MNL BM K150 117. 20826/1871. - Sáros vármegye; 118. 23816/1871. - Gömör és Kis-Hont vármegye; „A tisztviselo” nem fó hanem csak szolgabiró néven a tervezett alsz[olga]biró pedig segédsz[olga]biró czimen nevezendö." - MNL BM K150 117.21799/1871. - Bars vármegye; „A járási szolgabiráknak föszolgabirákká elnevezését mint a törvénnyel ellenkezöt helyben nem hagyhatom" - MNL BM K150 118. - 22326/1871. - Komárom vármegye. 
illetékességének szem elött tartásával körvonalaztatott." 577 Sáros vármegye azonban jelezte, hogy ezzel nem ért egyet, ugyanis ez ellenkezik a törvény 62. \$-ával, amely szerint az egyes tisztviselők hagyományos nevei megtarthatók lennének. Emellett azzal érveltek, hogy a korábbi tervezetükben amiatt jelölték meg a járásokat vezető tisztviselőket föszolgabíróként, hogy az alszolgabírói tisztség betöltőit az előléptetés lehetőségével motiválni tudják. ${ }^{578}$

Gömör és Kis-Hont vármegye a módosításhoz mellékelt kísérőszövegében úgy fogalmazott, hogy a minisztériumi meghagyásnak megfelelően kiigazították a tervezeteket, és a tisztviselők hatáskörét körvonalazó tervezetben ezzel egyezően a szolgabíró titulust alkalmazták. ${ }^{579} \mathrm{Az}$ újonnan felterjesztett tervezeteik közül abban, amely a tisztviselők fizetését határozta meg, valószínűleg tollhibából, továbbra is a főszolgabíró elnevezést használták. ${ }^{580} \mathrm{~A}$ belügyminisztériumi tanácsos emiatt ismételten figyelmeztette a vármegyét a hibás fogalomhasználatra. ${ }^{51} \mathrm{~A}$ minisztérium felhívására azonban nem reagált a törvényhatóság, de az sem kizárt, hogy a levéltári forrás hiányos.

Komárom vármegye azonban a belügyminisztériumi felhívás ellenére sem fogadta el a föszolgabírói elnevezés elhagyását. ${ }^{582}$ Sáros vármegyéhez hasonlóan a 62. \$-ára hivatkoztak a köztörvényhatósági törvénynek, mivel álláspontjuk szerint „a gyakorlat által törvényesitett" szokásjognak megfelelően a magyar vármegyékben a fö- és alszolgabírói elnevezést használják, mióta a tisztviselők számának szaporítása szükségessé tette a szolgabírák számának növelését. Ezáltal amellett érvelnek, hogy a szokásjogot kell figyelembe venni ebben az esetben a törvényekben használt „iudex nobilium” elnevezés helyett. Erre válaszul a belügyminisztérium az érvekre nem reagálva felhívta a vármegyét az általa helyesnek tartott álláspont elfogadására. Ekkor már a vármegye közönsége a miniszteri tanácsosok által képviselt álláspontnak megfelelően korrigálta az elnevezést, azonban hangsúlyozták, hogy álláspontjuk mellett kitartanak, és csupán a közigazgatási szervezet hatályba léptetésére kitűzött időpont közeli volta miatt tekintenek el ettől. ${ }^{583}$

Csanád vármegye esetében is hasonló probléma merült fel, ugyanis az 1871. július 3-án felterjesztett első tervezetben a törvény szövegének megfelelően szolgabírákat szerepeltetett a törvényhatóság közgyűlése a tisztikarban. ${ }^{584} 1871$. október 2 -án azonban a vármegye a tiszti karhatásköréről szóló javaslatát is megküldte a belügyminisztériumnak,

577 MNL BM K150 117.28287/1871.

578 MNL BM K150 117.27062/1871.

579 MNL BM K150 118. 32032/1871.; 32051/1871.

580 MNL BM K150 118.32051/1871.

581 „Minthogy a megyék közönsége a fószolgabiró elnevezéshez ez úttal is ragaszkodik, ezen törvénybe ütközó megállapodásnál pedig mint azt a f.évi oktober 19-én 23816 sz. a. kelt rendeletemben is már kijelentettem helyben nem hagyhatom, föl hivom a megyék közönségét, hogy a föszolgabirói elnevezésnek szolgabiróval, 's ebböl kifolyólag a fószolgabirói segéd elnevezésnek pedig szolgabirói segéddel leendö felcserélése iránt, a' jobban [sic!'] határozzon 's létre jött megállapodást tudomásomra hozni ne késsék." - MNL BM K150 118. $32051 / 1871$.

582 MNL BM K150 118.30274/1871.

583 MNL BM K150 118.34064/1871.

584 MNL BM K150 117. 17803/1871. 
amelyben konzekvensen föszolgabíráknak nevezték a járási tisztviselőket, így a belügyminisztérium figyelmeztette őket, hogy korrigálják ezt a pontatlanságot és tegyenek jelentést ennek megtörténtéről. ${ }^{585} \mathrm{~A}$ jelzett hiba javításával ennek megfelelően a vármegye állandó bizottmánya a soron következő ülésén bízta meg a föjegyzőt. ${ }^{586}$

Aranyosszék közönsége szintén eltért a szolgabírói elnevezéstől. Tervezetében mindenhol következetesen dullónak nevezte a járást vezető tisztviselőt. Ezt az elnevezést az erdélyi székely székek alkalmazták a közigazgatási, közbiztonsági és bírói feladatait ellátó tisztségviselőikre, akik a szolgabírákhoz hasonló funkciót töltöttek be. ${ }^{587}$ Csupán egy helyen szerepeltette a törvényhatóság közönsége a megfelelő elnevezést, ugyanis az alsó középszintű közigazgatási egységeiket szolgabírói vagy dullói járásnak titulálták. A belügyminisztérium által a tervezetekről készített összefoglaló ezzel szemben a járási tisztviselőket szolgabíróként szerepeltette és a tanácsosok Aranyosszéket így nem is hívták fel a korrekcióra. ${ }^{58} \mathrm{~A}$ föszolgabírói elnevezés kiküszöbölésénél tapasztalt következetesség fényében, különös, hogy ezt a megoldást nem kifogásolta a minisztérium. Érdemes ugyanakkor megjegyezni, hogy Aranyosszék egyike volt a legkisebb törvényhatóságoknak, így képtelen volt megfelelni a törvény támasztotta kívánalmak jelentős részének, ezért már az első tervezetüket minden korrekció nélkül jóváhagyták a tanácsosok.

Nagy-Kikinda kerület esetében szintén engedélyezte a minisztérium a tanácsnok megnevezés használatát a szolgabíró helyett, amit azzal indokolt a törvényhatóság, hogy a kerületi lakosság már megszokta az elnevezést és a hagyományos tisztségek fenntartására lehetőséget nyújtott a törvény. A belügyminiszteri tanácsos elöször szerepeltette a kifogást a választervezetében, amely figyelmeztette a törvényhatóságot arra, hogy a tanácsnoki címet a törvény szövegével összhangban lévő szolgabíróra módosítsa, de ezt utólag lehúzták a tervezet ellenőrzése során. ${ }^{589}$

A Hajdú kerület rendhagyó módon eltekintett a szolgabírák rendszeresítésétől, mert szükségtelennek tartották a tisztséget a törvényhatóságban. Az 1870:XLII. tc. értelmében ugyanis a rendezett tanácsú városok külön járásokat alkottak, és a kerület területén csupán rendezett tanácsú városok voltak. ${ }^{590} \mathrm{~A}$ Szepesi XVI város kerülete a Hajdú kerülethez hasonló berendezkedéssel rendelkezett, így csupán egy szolgabírót alkalmaztak tisztikarukban, aki a rendezett tanácsot nem tartó községek esetében látta el a járási teendőket. ${ }^{591}$

\footnotetext{
585 „A járási elsö tisztviselö határozottan fószolgabirónak neveztetik, ezen elnevezés pedig a törvényhatóságok rendezéséröl szóló törvény rendeletével, mely a járási elsö tisztviselöt nem fó hanem szolgabirónak czimezi, ellenkezik." - MNL BM K150 117.27191/1871.

586 MNL BM K150 117.32776/1871.

587 MNL BM K150 152. 1872:II.2. 25042/1869. - Háromszék; 86. rendelet az erdélyi törvényhatóságok helyreállításáról.

588 MNL BM K150 117.20171/1871.

589 MNL BM K150 118.24696/1871

590 MNL BM K150 118. 23336/1871.

591 MNL BM K150 118.31576/1871.
} 


\subsection{Alszolgabíró vagy segédszolgabíró?}

A föszolgabírói elnevezést használó vármegyéknél merült fel a leggyakrabban, hogy alszolgabírákat is rendszeresítsenek a járási feladatok ellátására, így Bars vármegye, Sáros vármegye, Komárom vármegye, valamint Gömör és Kis-Hont vármegye is szerepeltette ezt a tisztséget a tervezeteik első változatában, ahogy az a fentebbiekből már kitűnt. ${ }^{592}$ Egyedül Békés vármegye kívánta az alszolgabírói elnevezést úgy beemelni közigazgatási szervezetébe, hogy nem föszolgabírónak címezte a járás élén álló hivatalnokot. ${ }^{593} \mathrm{Az}$ alszolgabírák azonban nem ugyanazt a szerepet töltötték volna be az egyes vármegyékben. Békés, Bars, Komárom és Gömör és Kis-Hont vármegyék a járás élén álló tisztviselők segédeiként kívánták rendszeresíteni az alszolgabírákat. ${ }^{594}$ Ezzel szemben Sáros vármegye a föszolgabíráktól függetlenül az alszolgabíráit az egyes kerületek élére helyezte volna, mivel az újoncozási feladatoktól eltekintve a fö- és alszolgabírákat azonos hatáskörrel látták volna el. ${ }^{595}$

Békés vármegye, Komárom vármegye, valamint Gömör és Kis-Hont vármegye azzal indokolták az alszolgabírói tisztség szükségességét, hogy a nagyméretű és népességü járásaikban ezzel megakadályozhatják a szolgabírák leterheltségét és megoldhatják helyettesítésüket. ${ }^{596} \mathrm{Az}$ érvelés helyesnek mutatkozott, a három vármegye harmincezer fö körül szabta meg járásai méretét, míg a legtöbb törvényhatóság jócskán ez alatt maradt az alsó középszintű közigazgatási egységeinek meghatározásakor. Komárom vármegye részletesen szabályozta, hogy az alszolgabíró a főszolgabíró felügyelete alatt köteles eljárni, így önálló ügyintézésre nem lett volna feljogosítva és a föszolgabíró utasításainak megfelelően kellett volna eljárnia. Az alszolgabíró tevékenysége miatt pedig csak akkor lenne felelősségre vonható, ha a föszolgabírót felügyeleti mulasztás nem terheli.

Liptó vármegye már 1871. július 4-én a szervezési munkálatok megkezdésekor kérte a belügyminisztérium útmutatását az alszolgabírói tisztséggel kapcsolatban. A törvényhatóság a már említett vármegyékhez hasonlóan a szolgabírák helyettesítését kívánta megoldani az alszolgabírák rendszeresítésével. A belügyminisztérium azonban már ekkor egyértelmüen kifejtette álláspontját: „Alszolgabirák nem szervezhetők, miután a törvény csak szolgabirákat emlit, azok helyettesitésére vagy kisegitésére azonban segédek alkalmazhatók, kik a szolgabiró megbizásából járnak el.' ${ }^{\text {997 }}$ Ennek megfelelően a minisztériumi vizsgálatok egységesen elutasították az alszolgabírói tisztség fenntartását azzal az indokkal, hogy a

\footnotetext{
592 MNL BM K150 117.21799/1871.; 20826/1871.; 118. 23816/1871.; 22326/1871.

593

594

595

596 MNL BM K150 117.21161/1871.

MNL BM K150 117.21161/1871.; 21799/1871.; 118. 23816/1871.; 22326/1871.

MNL BM K150 117.20826/1871.

„A járási szolgabirák mellé alszolgabirák rendszeresitését azon okból látta jónak a megye javaslatba hozninehogy a nagy kiterjedés és népességgel biró járásokban hátramaradások legyenek és hogy a járásbeli szolgabiró akadályoztatása esetében helyettes által kellön pótolva legyen s így a közszolgálat érdekében hátramaradás ne történjék." - MNL BM K150 117.21161/1871. - Békés vármegye; 118. 23816/1871. - Gömör és Kis-Hont vármegye; 22326/1871. - Komárom vármegye.

MNL BM K150 117. 16986/1871.
} 
törvény járási tisztviselőkként csak a szolgabírót és az írnokot jelölte meg. ${ }^{598}$ A Liptó vármegyének küldött leiratban már felvillantotta a belügyminisztériumi tanácsos annak a lehetőségét, hogy egy segéd kerülhet a törvényhatóságok közigazgatási szervezetébe a szolgabírák helyettesítésére vagy kisegítésére. Az alszolgabírák helyett így a minisztérium az írnok mellett végül a szolgabírói segéd vagy szolgabírósegéd alkalmazásának lehetőségét engedélyezte, amely tisztség bevezetése ugyan nem szerepelt a törvényben, de azzal nem is ellenkezett. ${ }^{599}$ A szolgabírósegéd megjelenése érdekes példája a minisztériumi jogalkalmazásnak az 1870:XLII. tc. esetében.

A belügyminisztérium azt a megoldást, hogy a szolgabírósegédi állomások létrehozatalát engedélyezni fogja, érezhetően 1871 szeptemberében, az első tervezetek megerősítése alkalmából dolgozta ki. ${ }^{600}$ Ekkor javították „áthúzással” a már elkészült választervezetekben egységesen a segédszolgabíró elnevezéseket szolgabírósegédre Békés és Sáros vármegye esetében is. Ezt követően már egységesen, ugyanazzal a meghatározással kérték a vármegyéktől szükség esetén e tisztség rendszeresítését.

Arad és Veszprém vármegye viszont a fent említett vármegyéktől eltérően első tervezeteikben nem az alszolgabíró, hanem a segédszolgabíró elnevezést alkalmazták. Arad vármegye elismerte, hogy erre vonatkozóan a törvényben nincs rendelkezés, de a járások számának csökkentése miatt várhatóan megnövekedő szolgabírói munkateher miatt szükségesnek tartották a segédek biztosítását. ${ }^{601}$ Veszprém vármegye azzal magyarázta a segédszolgabírák alkalmazását, hogy a szolgabírák helyettesítése, a felelősségre vonás és a tekintély szempontjából is alkalmasabbnak tartják őket a feladatok ellátására, mint a szolgabírói írnokokat. ${ }^{602} \mathrm{~A}$ belügyminisztérium ezekben az esetekben is majdnem ugyanazon indoklással kérte ennek felcserélését a szolgabírósegéd meghatározásra. ${ }^{603}$

598 „A javaslatba hozott alszolgabirói állomásokat illetóleg megjegyzem, hogy nem ellenkezik ugyan a törvény szellemével, hogy a tényleges szükséghez képest a járási szolgabiró mellé egy egy segédi állomás szerveztessék, mindazonáltal az alszolgabirói elnevezés szolgabirói segéddel cserélendö föl." - MNL BM K150 117. 21161/1871. - Békés vármegye; 21799/1871. - Bars vármegye; 20826/1871. - Sáros vármegye; 118. 23816/1871. - Gömör és Kis-Hont vármegye. 22326/1871. - Komárom vármegye.

599 MNL BM K150 117.21161/1871. - Békés vármegye; 17731Sz/1871. - Arad vármegye; 21799/1871. - Bars vármegye; 20826/1871. - Sáros vármegye; 118. 23816/1871. - Gömör és Kis-Hont vármegye; 22326/1871. - Komárom vármegye.

600 MNL BM K150 117.21161/1871. - Békés vármegye; 21799/1871. - Bars vármegye; 20826/1871. - Sáros vármegye.

601 MNL BM K150 117. 17731Sz/1871.

602 „Tetemesen megnagyobbitott járásban elöforduló sok oldalú, slegtöbbször halasztást nem szenvedhetō teendök, a szolgabirónak hivatalos távollétében, vagy történhetó egyébkénti akadályoztatása esetén, egy a szolgabiró által kinevezendö, 's el is bocsátható irnoknál mind tekintélyre, mind képeségre, mind feleletre vonhatásra nézve elöbb keló hivatali egyéniség által nyerjenek elintézést, járásonként egy, (...) igy az egész megyére nézve - 5 segédbirónak alkalmazását kikerülhetetlennek találtuk." - MNL BM K150 118. 22336/1871.

${ }^{603}$ „Nem ellenkezik ugyan a törvény szellemével hogy a tényleges szükséghez képest, a szolgabiró mellé egy egy segédi állomás szerveztessék, szabatosabbnak tartom azonban ha a szolgabiró oldala mellé tervezett segéd szolgabirói elnevezés szolgabiró segéddel cseréltetik föl." - MNL BM K150 117. 17731Sz/1871. - Arad vármegye; „A mennyiben a törvény szellemével nem ellenkezik nem leend észrevételem, hogy a járási szolgabiró a tényleges szükséghez képest segédszemélyzettel elláttassék, azonban a tervezett segéd birói megnevezés szolgabiró segéddel cserélendö föl, a ki nem önállóan hanem minden ügyben csak a szolgabiró megbizásából, annak nevében és felelössége alatt járhat el." - MNL BM K150 118. 22336/1871. - Veszprém vármegye. 
A másik hasonló eltérés Hont vármegye és Trencsén vármegye tervezeteiben jelentkezett, mivel e törvényhatóságok az esküdti címet kívánták megőrizni, amelynek helyébe a belügyminisztérium a szolgabírósegéd alkalmazását javasolta számukra. ${ }^{604}$ Pozsony vármegye viszont szolgabírói segédek kinevezésére kért lehetőséget a belügyminisztériumtól, amit azzal indokolt, hogy a szolgabíró egy írnokával nem lenne képes ellátni feladatait, mivel a katonai ügyek magukban egy teljes személyt kívánnak és útibiztos hiányában a közmunkával kapcsolatos feladatokat is teljes mértékben a szolgabírónak kell elintéznie. Emellett pedig a tisztség bevezetését jó megoldásnak tartották arra, hogy a közigazgatási pályára készülő ifjak vármegyei karrierjének első lépcsőfokaként szolgáljon. Hangsúlyozták, hogy a szolgabírói írnok pozíciója erre nem alkalmas, mert nagyfokú kiszolgáltatottsága miatt nem vonzó a szakképzett fiatalság számára. A vármegye közönsége elsősorban az utak és a hidak fenntartásával járó feladatokat kívánta a szolgabírósegédek hatáskörébe utalni. A törvényhatóság elismerte, hogy az általa kezdeményezett megoldást a törvényben nem szabályozták, viszont abbéli reményét fejezte ki, hogy a minisztérium elfogadja „a törvényszabta keretnek specialis viszonyaikhoz idomitását". ${ }^{05}$ E vármegyékhez hasonlóan Kővár vidék a szolgabírák mellé bevezetett írnokokat címezte szolgabírósegédeknek, mivel ez a megoldás megegyezett a belügyminisztérium által megvalósítottal, így jóváhagyták a törvényhatóság tervezetének e részét. ${ }^{606}$

A belügyminisztérium minden olyan vármegye számára, ahol felmerült a szolgabírósegéd szükségessége, egységesen kifejtette, hogy a szolgabírósegéd „nem önállóan hanem minden ügyben csak a szolgabiró nevében, megbizásából és felelössége alatt járhat el." ${ }^{607}$ A belügyminisztérium ezáltal egyértelműen a szolgabírónak alárendelt segédszemélyzet meghonosítását engedélyezte a vármegyék számára, akiknek a tevékenységéért a szolgabíró tartozott felelősséggel. Gömör és Kis-Hont vármegye ennek megfelelően a következőképpen határozta meg a szolgabírósegédek hatáskörét: „A szolgabirói segéd saját szobában a reábizott ügyeket mindenkor a szolgabiró utasitása smeghagyása szerints mindenben a szolgabiró nevében, megbizásából, 'sfelelössége alatt jár el." ${ }^{008}$ Ebből is kitünik, hogy a szolgabírói írnoknál egy jóval önállóbb hivatalnoknak tartották a vármegyék a szolgabírósegédeket.

A szolgabírósegéd kapcsán a legvitatottabb probléma az volt, hogy miképpen nyerje el tisztségét. A belügyminisztérium a legtöbb vármegye esetében a szolgabírósegéd kapcsán nem nyújtott támpontot arra nézve, hogy választás vagy kinevezés alá esik-e a vármegyében ez a pozíció ${ }^{609}$ Erre vonatkozó utalás az általam vizsgált vármegyék esetében

„Az esküdti czimet mellözve, az illetö segéd tisztviselöre nézve a szolgabirói segéd elnevezést használja.” MNL BM K150 118. 31986/1871. - Hont vármegye; 117. 20991/1871. - Trencsén vármegye.

MNL BM K150 118.26616/1871. MNL BM K150 118. 22499/1871.

607 MNL BM K150 117.21161/1871. - Békés vármegye; 17731Sz/1871. - Arad vármegye; 21799/1871. - Bars vármegye; 20826/1871. - Sáros vármegye; 118. 23816/1871. - Gömör és Kis-Hont vármegye; 28726/1871. - Hont vármegye. 
Arad vármegyénél található, amikor a belügyminiszteri tanácsos a következő választ adta a törvényhatóság választásra vonatkozó felvetésére: „A szóban levő állomásnak betöltését illetóleg pedig határozottan ki kell jelentenem a megye közönségének, hogy ez a törvény kötelezö erejénél fogva nem választás hanem kinevezés útján eszközölhetö." ${ }^{10} \mathrm{~A}$ minisztérium azonban ekkor sem adott útmutatást azzal kapcsolatban, hogy mely tisztviselő jogosult a szolgabírósegéd kinevezésére. Minden bizonnyal egyértelműnek tartották, hogy a vármegyék a segédszemélyzethez fogják besorolni a létrehozott vármegyei állást a szolgabírósegéd alárendeltségének és segédi feladatainak hangsúlyozása miatt. A segédszemélyzethez számított személyek kinevezésére pedig az $53 . \$ \mathrm{~g}$ ) pontja alapján a főispán volt jogosult. Ezt igazolják a Hont vármegye tervezeteinek megerősítését célzó előfogalmazványok szövegei is, bár különös, hogy ezeket a részeket mindkét esetben végül kihúzta a szövegtervezetet ellenőrző belügyminiszteri tanácsos. ${ }^{611}$ Ezekre a javításokra azonban valószínűleg nem a megállapítás helytelensége miatt került sor, hanem azért, mert a belügyminisztérium Hont vármegyét az esküdti pozíció elhagyására próbálta szorítani, így nem akarta ezt annak hangsúlyozásával nehezíteni, hogy az ennek pótlására ajánlott tisztséget nem választhatja a vármegye közönsége.

Arad vármegye a belügyminisztérium állásfoglalásával ellentétes módon választani kívánta segédszolgabíráit, amelyhez annyira ragaszkodott, hogy kinevezés esetén nem vélte szükségesnek a tisztség létrehozatalát. ${ }^{612}$ Hont vármegye szintén kitartott a szolgabírósegédek választhatósága mellett miután többszöri levélváltást követően elfogadta, hogy esküdt helyett csupán szolgabírósegédet rendszeresíthetnek. ${ }^{613}$

Hont vármegye az esküdt választhatósága kapcsán a belügyminisztériummal folytatott vitájában nyilvánvalónak tartotta, hogy a szolgabírósegédet a szolgabíró nevezi ki. ${ }^{614}$ Ennek az lehetett az oka, hogy a szolgabíró volt az egyetlen tisztviselö a vármegye tisztikarában, aki maga nevezhette ki írnokát. Emiatt juthatott a törvényhatóság arra a következtetésre, hogy más segédjét is a szolgabíró jogosult kinevezni.

A szolgabírósegéd és más tisztviselők hivatalba juttatása kapcsán Liptó vármegye föispánja kért felvilágosítást 1871 . november 15 -én, ami alapján egyértelmüen megismerhető a belügyminisztérium álláspontja a kérdésben. A minisztériumhoz intézett kérdés arra irányult, hogy kik tartoznak a segéd- és kezelőszemélyzet körébe, akiknek a kinevezése az 1870: XLII. tc. 65. §-a alapján a föispán hatáskörébe tartozik. A föispán kiemelte, hogy

610 MNL BM K150 117. 17731Sz/1871.

${ }^{611}$ „Magától értetvén hogy a szolgabiró segédet a törvény 53. S-a g. pontja szerint a fóispán nevezendi ki” MNL BM K150 118. 28726/1871.; „És miután a szolgabirói segéd a törvényböl kifolyólag önálló hatáskörrel nem leend felrubázva, hanem csak az lesz feladata, hogy az illetö szolgabirónak teendói elvégzésében segitségére legyen, a megye közönségének azon megállapodása hogy ezen állomás választás útján töltendi be, el nem fogadhatván, figyelmeztetem, hogy a szolgabirói segéd a segéd és kezelö személyzethez tartozik, és ennélfogva ezen állomás nem választás, hanem az 1870 évi XLII. t. cz. 539 g. pontja értelmében csak föispáni kinevezés útján tölthetik be." - MNL BM K150 118.31986/1871.

${ }_{612}$ "[A segédszolgabirák] rendszeresitését csak abban az esetben méltóztassék engedélyezni, ha azoknak nem kinevezés, hanem rendszeres választás útjáni betöltése fog kimondatni, ellenesetben a tervezet segédszolgabirói áláásokat részünkröl fenttartani nem óhajtjuk." - MNL BM K150 117.17731Sz/1871.

613 MNL BM K150 118.33141/1871.; 31986/1871.

${ }^{614}$ MNL BM K150 118.31986/1871. 
az 1848 előtti szabályozás nem tud támpontot nyújtani a jogértelmezés számára, mert a gyakorlat ingatag volt. A fojjegyző helyetteseit a fóispán nevezte ki, viszont az alorvost a közgyűlés választotta. A vármegye élén álló méltóság azért kérte előre a belügyminisztérium felvilágosítását, mert súrlódásokra számított a tisztújításkor a törvényhatósági bizottság és saját személye között. A föispán külön hangsúlyozta, miszerint nem egyértelmü, hogy az árvaszéki elnök, ülnök és a szolgabírósegéd segédszemélyzetnek minősül-e. Véleménye szerint példának okáért a pénztárnok, a megyei mérnök és a számvevő inkább a kezelőszemélyzethez sorolható. ${ }^{615}$

A belügyminisztérium november 29-én kelt válaszleiratában akképpen döntötte el a kérdést, hogy az 1870:XLII. tc. 57. §-ában felsorolt központi (alispán, jegyző, tiszti ügyész, árvaszéki elnök és ülnök, pénztárnok, föorvos, főmérnök, levéltárnok, főszámvevő, közgyám, állatorvos) és kültisztviselői (szolgabíró, járási orvos, járási mérnök, járási számvevő, járási közgyám) állomásokat, a konkrétan ebből a körből kiemelt levéltárnoki poszt kivételével, a 68. \$-ban meghatározott szabályok szerint a törvényhatósági bizottság választja. Az itt fel nem sorolt alkalmazottakat pedig a fóispán nevezhette ki az 53. \$g) pontjának megfelelően, akik ennek következtében nem a tisztviselők körébe tartoztak, hanem a segéd- és kezelőszemélyzethez. ${ }^{616}$

A kérdés fontosságát mutatja, hogy 1871. december 1-jén a föispán már táviratilag sürgette a belügyminisztériumi választ, mivel vármegyéjében „tisztválasztási pártok” alakultak. A belügyminisztérium erre válaszul a már ismertetett világos útmutatást nyújtotta arra nézve, hogy mely tisztviselők esnek választás alá és melyek nyerik el a tisztségüket föispáni kinevezés útján. Ennek ellenére a vármegye szintén táviratban konkrét tisztségek esetén ismét a belügyminisztériumhoz fordult felvilágosításért. A válaszleiratok viszont ezt az egyértelmű álláspontot bizonytalanná tették. Az első kérdés esetében ugyanis a minisztérium megállapította, hogy a megyei orvos választás alá esik. ${ }^{617} \mathrm{~A}$ megjelölt 57. §-ban a föorvos a központi tisztviselők között volt felsorolva, így efelől nem igazán lehetett kétség. A másik kérdés viszont az aljegyzők választhatóságára irányult, amelyre pontosan ugyanezt a választ kapta a törvényhatóság. ${ }^{618} \mathrm{Ez}$ az útmutatás azonban több problémát is felvet. Az említett szakasz ugyanis csupán jegyzőt említ központi tisztségviselőként, amely inkább a föjegyzőre vonatkoztatható, mint az aljegyzőkre. Különösen annak fényében érdekes ez a megoldás, hogy a szolgabírósegéd, aki a szolgabíró segítője és helyettese, kinevezés alá esik a minisztérium álláspontja szerint, viszont az aljegyzők, akik szintén segítőjeként és helyetteseként funkcionálnak a föjegyzőnek, már választás útján nyerik el tisztségüket.

MNL BM K150 117.30834/1871.

„[A] köztörvényhatóságok rendezéséröl szóló törvény a tiszti állomások betöltési módozata iránt az ország törvényhatóságainál eddig divott különbözö gyakorlatot megszüntetvén egyöntetü eljárást rendel el; - a törvény $57 i k$ S-ában elö nem sorolt azon tiszti állomások pedig, melyek a megye jövö szervezeti munkálatában megállapitva lönek a segéd és kezelö személyzet sorozatába esnek s mint ilyenek a törvény 53ik Sa g pontjáboz képest fóispáni kinevezés által fognak betöltetni.” - MNL BM K150 117. 30834/1871.

MNL BM K150 117.30834/1871.

„A megyei aljegyzők, a tiszteletbeliek kivételével, választás alá esnek.” - MNL BM K150 117.30834/1871. 
A belügyminisztérium álláspontja tehát az volt, hogy a szolgabírósegédek csak kinevezés útján nyerhetik el hivatalukat. Ennek hangot is adott a tisztség választhatósága mellett érvelő Arad vármegyének küldött válaszleirataiban. ${ }^{619}$ Arad vármegye újból felterjesztett tervezeteiben viszont nem található intézkedés arra nézve, hogy elfogadták-e a belügyminisztérium felvilágosítását. Mindenesetre gyanút keltő, hogy a szolgabírósegédek kapcsán megjegyezték, miszerint csupán az első választási időszakban tervezik „tesztelni” a tisztség szükségességét. ${ }^{60}$ Hont vármegye viszont a szolgabírósegédi elnevezést elfogadva egyértelmủen úgy határozott, hogy föispáni kijelölés mellett a törvényhatósági bizottság fogja választani őket. ${ }^{621} \mathrm{~A}$ belügyminisztériumi tanácsos végül miniszteri utasításra elfogadta a vármegye e rendelkezését. ${ }^{622}$ Érdemes megjegyezni, hogy a törvényhatóság határozatában szereplő főispáni kijelölés is kétségeket ébreszt, mivel az 1870: XLII. tc. alapján a főispáni kijelölés rendi hagyománya elenyészett, a tisztségviselöi jelöltek névsorát a 68. § értelmében a kijelölő választmány volt jogosult összeállítani. ${ }^{623} \mathrm{~A}$ belügyminisztériumnak azonban erre vonatkozó észrevétele nem volt.

A szolgabírósegédek megválasztásával kapcsolatos anomáliák arra az alapvető problémára vezethetők vissza, hogy az 1870:XLII. tc. adós maradt a tisztviselők körének pontos meghatározásával. Emellett pedig nem szabta meg azt sem, hogy mely alkalmazottak tartoztak a segéd- és kezelőszemélyzethez. Ezt a hiányosságot a jogalkotó a későbbiekben sem küszöbölte ki. ${ }^{624}$ Ezt a problémát így leggyakrabban a törvényhatóságok szervezési és müködési szabályzatai korrigálták.

\subsection{Az esküdti pozíció kiiktatása a polgári közigazgatás szervezetéből}

A vármegyék ragaszkodása a rendi hagyományokhoz a tervezetekben egyértelműen érzékelhető, mivel annak ellenére, hogy az 1870:XLII. tc. kiiktatta az esküdti tisztséget a közigazgatási szervezetből, több vármegyei munkálat igyekezett azt valamilyen módon az általuk létrehozott tisztikarban megőrizni. Gömör és Kis-Hont vármegye első tervezetében a járási tisztviselők (a főszolgabíró és az alszolgabíró) mellé esküdti címmel való felruházással még egy-egy írnokot rendelt. Ezt azzal magyarázta, hogy ezáltal az

619 „A szóban lévö állomásnak betöltését illetöleg pedig határozottan ki kell jelentenem a megye közönségének, hogy ez a törvény kötelezö erejénél fogva nem választás hanem kinevezés útján eszközölhetö." - MNL BM K150 117. 17731Sz/1871. - Arad vármegye.

${ }^{620}$ „Szolgabirói segédi állásokat csak is az elsö választási idöszakra, tehát 6 évre, mely idö alatt további szükségességük avagy feleslegességük ki fog tünhetni, rendszeresitjük.” - MNL BM K150 117. 32702/1871.

${ }^{621}$ „Kétrendü határozatunk értelmében - a szolgabirói segédeket ezentúl is a - megye közönsége által ohajtjuk - föispáni kijelölés mellett - választani. Miért is tisztelettel kérjük Exczellencziádat, hogy Hont megyének már most az uj megyeszervezésre vonatkozó, ez egyetlen, de forró kivánatát vissza utasitani ne méltóztassék." - MNL BM K150 118.33141/1871.

${ }^{622}$ „Minister úr ö nagyméltóságától nyert szóbeli utasitás folytán, tudomásul vétetvén.” - MNL BM K150 118. 33141/1871.

623 STIPTA 1995a, 301.

624 KMETY 1911a, 148. 
írnokok feletteseik által kisebb ügyekben önálló működésre is felhasználhatóvá válnak. A belügyminisztérium ennek megerösítését szigorúan elutasította azzal érvelve, hogy az esküdt a szolgabíró bírótársa volt, amelyre a továbbiakban nem lesz szükség, így a helyére az írnokok kerüljenek. ${ }^{625} \mathrm{~A}$ vármegye tudomásul vette a kérést és ennek megfelelően módosította járási szervezetét. ${ }^{626}$

Zala és Szepes vármegye szintén a jogalkotó által írnokként meghatározott segédszemélyzetet kívánta esküdtként megnevezni. ${ }^{627} \mathrm{~A}$ belügyminiszteri megerösítés során azonban figyelmeztették a törvényhatóságokat, hogy a törvény értelmében írnokként kell megjelölni a tisztséget. Temes vármegye is esküdt alkalmazásával vélte megoldhatónak a szolgabíró túlzott leterheltségét, mivel az esküdtekre bízta volna a járási közgyám feladatait. ${ }^{628}$ Azzal indokolta tervezetében az esküdti elnevezés megtartását, hogy ezáltal olyan feladatokat is elláthatnának, amit járási közgyámként nem tehetnének meg, és a segítségükkel a szolgabírák helyettesítése is megoldható lenne. Temes vármegye hangsúlyozta, hogy ezáltal egy, nem a szolgabíró alárendeltségében működő tisztviselőt kívánnak beemelni a közigazgatási szervezetükbe. Emellett a lakosság „ősi” intézmények iránti ragaszkodásával magyarázta az esküdti cím használatát, amelyhez a jogalapot a törvény 62. §-ának rendelkezéseiben találta meg, aminek értelmében a tisztviselők hagyományos nevei fenntarthatók. Trencsén vármegye a szolgabírák mellett esküdtek és írnokok alkalmazását is kívánta, de a belügyminisztérium az esküdti megnevezés továbbélését ebben a formában sem engedélyezte, ugyanis inkább a segédi állomások létesítését preferálta. A vármegyei közgyűlés azért kívánt a szolgabíró felelőssége alatti segédszemélyzetet létrehozni, mert ez a hivatal célszerúbb, mint „a patriarchális zamatú szolgabirô" egyszemélyi vezetésével fenntartani a járási igazgatást. ${ }^{629}$

A szolgabírói hivatallal kapcsolatos tisztségek meghatározása esetében a legérdekesebb problémákat Hont vármegye szervezési munkálatai vetették fel. Hont vármegye tizenkét szolgabírája mellé tizenkét esküdtet kívánt alkalmazni járásaiban, ${ }^{630}$ akiket a vármegye közönsége választott volna. Indoklásában elismerte, hogy ez a törvény szigorúan vett szövegével ellenkezik, azonban a vármegye közönsége ebben az esetben is a már említett 62. \$-ra hivatkozott, mivel véleményük szerint a köznép ragaszkodik a hagyományos „eskütti” elnevezéshez. A vármegye ezáltal kívánt helyettest és „rendes” segédet biztosítani a szolgabíró számára. Elképzelhetetlennek tartották, hogy ezt a funkciót el tudná látni egy, a szolgabíró által kinevezett és nem a vármegye által választott írnok. ${ }^{631} \mathrm{Az}$ esküdtszolgabiró által szolgaként és szolgafizetéssel felfogadott, majd elbocsátott, s még is a törvényhatóság költségén
tartott irnok - egyén képviselje nem egy esetben a megyei szolgabirót, s igy közvetve magát az uj megyei institutiot." - MNL BM K150 118. 28726/1871. 
jeikért a szolgabírák tartoztak volna felelősséggel, és kötelesek lettek volna a szolgabírák lakhelyén tartózkodni.

Erre válaszul a belügyminisztériumtól a szokásos reakciót kapta a vármegye: a szolgabíró mellé helyezhető segédszemélyzet, azonban nem a szolgabíró korábbi bírótársa az esküdt, hanem a szolgabírósegédek. ${ }^{632}$ Hont vármegye az e figyelmeztetések tükrében elöterjesztett második tervezetében továbbra is ragaszkodott a választott esküdti pozícióhoz, azzal indokolva álláspontját, hogy ez nagyobb erkölcsi legitimációt fog biztosítani számukra, mint a kinevezés. Emellett egyetértettek azzal a megoldással, hogy esküdtjéért a szolgabíró felelös. ${ }^{633}$

A belügyminisztérium a második alkalommal már keményebb hangot megütve figyelmeztette a vármegyét, hogy az összes törvényhatóság elfogadta az esküdtek kiiktatását a járási szervezetből, így már csak az egyöntetüség okán is elvárja, hogy Hont vármegye is alkalmazkodjon ehhez, és szolgabírói segédeket alkalmazzon helyettük. ${ }^{634} \mathrm{~A}$ vármegye erre válaszul immár harmadik felterjesztésében elfogadta az esküdtről a szolgabírói segédre való módosítást. ${ }^{635}$

\subsection{A szolgabírói írnok szerepe}

Az 1870:XLII. tc. a szolgabíró segédévé a szolgabírói írnokot rendelte. A szolgabírói írnokot a szolgabíró nevezte ki, utasíthatta és az ő felelőssége alatt végezte munkáját. Fizetését a törvényhatóság utalványozta. Az e törvény által meghatározott szabályok érvényesültek is azon vármegyék esetében, amelyek a szolgabírói hivatal részévé tették a szolgabírói írnokokat. ${ }^{636}$ Bars vármegye tervezetében arról rendelkezett, hogy a szolgabírói írnokok munkáját csupán az irodai tevékenységekre korlátozzák. Ezt azzal indokolták, hogy ez szolgálja a hivatal tekintélyének megóvását, mivel fizetésük anynyira alacsony, hogy esetükben óhatatlanul felmerülne a megvesztegetés gyanúja. ${ }^{637}$ Felsö-Fehér vármegye szintén az irodai munkára korlátozta tevékenységüket. ${ }^{638}$ Fogaras vidék a szolgabírói írnokok számára követelményként támasztotta, hogy megfelelően képzettek legyenek, mivel szükség esetén feladatuk lesz a szolgabírák helyettesítése is. A törvényhatóság adós maradt annak kifejtésével, hogy milyen képzettséget vár el ennek érdekében az írnokoktól. ${ }^{639}$

\footnotetext{
${ }^{632}$ MNL BM K150 118. 28726/1871.

633 MNL BM K150 118.31986/1871.

634 MNL BM K150 118.31986/1871.

635 MNL BM K150 118.33141/1871.

636 MNL BM K150 117. 22026/1871. - Felső-Fehér vármegye; 21272/1871. - Doboka vármegye; 20826/1871. - Sáros vármegye; 21800/1871. - Fogaras vidék.

637 MNL BM K150 117.28287/1871.

${ }^{638}$ „Kötelessége [a szolgabirói irnoknak] a szolgabirói irodán az iktatói - levéltárnoki - írnoki - s kiadoi teendöket pontosan elvégezni." - MNL BM K150 22026/1871.

639 MNL BM K150 117.21800/1871.
} 
Csongrád vármegye a szolgabírói írnokok esetében a többi vármegyétől eltérően járt el. A belügyminisztérium nem fogadta el az általuk az első tervezetben javasolt négy járást, ${ }^{640}$ így azok számát kettőre csökkentették. Ennek következtében viszont a szolgabírók túlzott leterheltségét elkerülendő, két-két írnokot rendeltek melléjük, akiket elsö- és másodrendü írnokként címeztek, amit a belügyminisztérium helyeslőleg tudomásul vett. ${ }^{641}$

\subsection{A közbiztonsági feladatokat ellátó járási személyzet}

A köztörvényhatósági törvény a szolgabírói írnok járási segédszemélyzetként való alkalmazását kötelező elemként határozta meg a vármegyék számára. Több vármegye azonban a szolgabírák számára a közbiztonsági hatásköreik megkönnyítése céljából egyéb szolgaszemélyzetet is biztosított. A vármegyék tervezeteiben nem minden esetben határozták meg pontosan, hogy a szolgaszemélyzet mely tisztviselő munkáját segíti, így csupán azokat a vármegyei alkalmazottakat vettem figyelembe, amelyeknél egyértelmủen kiderült, hogy járási feladatokat látnak el.

A hasonló hatáskörü segédszemélyzet tagjait különböző elnevezésekkel illették a vármegyék. Bars, Csongrád, Hont és Bereg vármegyében egy-egy tiszti hajdú segítette a szolgabírák munkáját. ${ }^{642}$ Zala vármegye, valamint Gömör és Kis-Hont vármegye egy-egy csendbiztost rendelt a járás élén álló tisztviselői mellé. ${ }^{643}$ Fejér vármegye és Kővár vidék úgy vélte, hogy egy csendbiztos két járás teendőit is megfelelően képes lesz ellátni. ${ }^{644}$ Kővár vidék emellett járásonként még egy-egy tiszti hajdút is alkalmazott. ${ }^{645}$ Békés vármegye járásonként egy csendbiztos, egy csendlegény és egy tiszti hajdú szolgálatba állítását vélte szükségesnek. ${ }^{646}$ Veszprém vármegye minden járásában a szolgabírák

munkáját tiszti katonák hivatalba állításával segítette. ${ }^{647}$ Felső-Fehér vármegye pedig arra kötelezte szolgabíráit, hogy szolgabírói pandúrokat vegyenek igénybe feladataik ellátása során. ${ }^{648}$

E vármegyei személyzet hatásköréről, munkájáról a tervezetek azonban kevés információt tartalmaztak. Gömör és Kis-Hont vármegye aképpen szabályozta csendbiztosainak hatáskörét, hogy „a csendbiztos és pandúrjai a szolgabirák rendelkezései alatt állanak”. ${ }^{649}$ Ezáltal már tekintélyes létszámú segédszemélyzet állt a szolgabíró rendelkezésére a vár-

\footnotetext{
640 MNL BM K150 117.21068/1871.

${ }^{641}$ „A járás tisztségviselöje a szolgabiró, mindegyik szolgabiró mellé két-két irnok adatik.”- MNL BM K150 117.27282/1871. 
megyében, mivel hat szolgabírói pandúr tartozott egy járáshoz a csendbiztos mellett. ${ }^{650}$ Kővár vidék ezzel szemben arra hivatkozva, hogy „a szolgabírák is kötelesek a csendre és rendre felügyelni" két szolgabírói járásra csupán egy csendbiztos alkalmazását rendelte el. ${ }^{61} \mathrm{Ha}$ összevetjük a két törvényhatóság szabályozását, akkor az észlelhető, hogy Kővár vidék esetében már nem annyira egyértelmü, hogy a csendbiztosok munkájuk során a szolgabírónak alárendelten jártak el. Ez azzal hozható összefüggésbe, hogy Erdélyben a kiegyezést megelőzően a császári és királyi csendőrség miatt nem alakult ki törvényhatósági közbiztonsági személyzet, ${ }^{652}$ így Kővár vidék újonnan hozta létre a csendbiztosi tisztséget. A csendőrség sorsáról a köztörvényhatósági törvény megszületésekor még nem született döntés. Ennek megfelelően megfigyelhető, hogy az erdélyi vármegyék kisebb létszámban vagy nem tették közigazgatási szervezetük részévé a közbiztonsági közegeket.

\subsection{A polgári kor szolgabírói hivatala}

A szolgabírói hivatal az általam vizsgált legtöbb vármegyében a törvényben megszabott módon szolgabíróból és szolgabírói írnokból állt. ${ }^{653}$ Csongrád vármegye pedig a korábban már ismertetett módon két-két írnokot alkalmazott szolgabírái mellé. ${ }^{654} \mathrm{~A}$ belügyminisztérium a törvényhatóságok igényére reagálva hozta létre a törvényből hiányzó szolgabírósegéd rendszeresítésének lehetőségét. Mint említettem, a tisztség bevezetése Békés, Arad, Bars, Sáros, Trencsén, Gömör és Kis-Hont, Komárom, Pozsony, Hont és Veszprém vármegyék, valamint Kővár vidék esetében merült fel a vizsgált törvényhatóságok közül. ${ }^{655}$ Kövár vidék mellett Arad, Bars, Trencsén, Gömör és Kis-Hont, Komárom, Pozsony, Hont és Veszprém vármegyék döntöttek a tisztség bevezetése mellett. ${ }^{656}$ Békés és Sáros vármegyék viszont elvetették azt. ${ }^{67} \mathrm{Az}$ utóbbi ezt azzal indokolta, hogy a választott és önálló alszolgabírák helyett a nem önálló szolgabírósegédi tisztség bevezetése elriasztaná az alkalmas embereket a pozíció betöltésétől. Inkább lemondtak arról, hogy Csanád vármegye; 21068/1871. - Csongrád vármegye; 21272/1871. - Doboka vármegye; 17808/1871. - Fejér vármegye; 22026/1871. - Felső-Fehér vármegye; 21800/1871. - Fogaras vidék; 22226/1871. Krassó vármegye; 27062/1871. - Sáros vármegye; 21797/1871. - Szepes vármegye; 21798/1871. - Zala vármegye; 118. 23346/1871. - Alsó-Fehér vármegye; 22592/1871. - Bereg vármegye; 24696/1871. - Nagy-Kikinda kerület; 22499/1871. - Kövár vidék; 31404/1871. - Küküllő vármegye; 22691/1871. - Nógrád vármegye; 25636/1871. - Zaránd vármegye.

MNL BM K150 118. 32051/1871.

MNL BM K150 118.22499/1871.

MNL BM K150 117.20171/1871. - Aranyosszék.

MNL BM K150 117. 20171/1871. - Aranyosszék; 31913/1871. - Békés vármegye; 17803/1871. MNL BM K150 117.27282/1871.

MNL BM K150 117. 21161/1871.; 17731/1871.; 21799/1871.; 20826/1871.; 28525/1871.; 118 23816/1871.; 22326/1871.; 26616/1871.; 28726/1871.; 31986/1871.; 22336/1871.; 22499/1871.

MNL BM K150 117. 32702/1871.; 28287/1871.; 28525/1871.;118. 32051/1871.; 34064/1871.; 26616/1871.; 33141/1871.; 30172/1871.; 22499/1871.

MNL BM K150 117.31913/1871.; 27062/1871. 
a szolgabírák mellé segédeket nevezzenek ki. Kövár vidék a többi törvényhatóságtól eltérően a szolgabírói írnokait kívánta szolgabírói segédként megnevezni, amely megoldást a belügyminisztérium el is fogadott. ${ }^{658} \mathrm{~A}$ szolgabírósegédet a tisztikarába beemelő vármegyék közül Arad, Bars, Trencsén, Gömör és Kis-Hont, Komárom és Veszprém vármegyék a járásaikban szolgabírói írnokokat is rendszeresítettek. ${ }^{659}$ Pozsony és Hont vármegyék viszont ezt nem tartották szükségesnek. ${ }^{660} \mathrm{Az}$ előbbi azonban végül 1872-ben, a törvény által létrejött közigazgatási szervezet első működési évében a segédek helyett mégis írnokok alkalmazását kérte. ${ }^{661} \mathrm{~A}$ szolgabírói segédek elterjedését mutatja a vármegyékben, hogy Boncz Ferenc 1876-ban megjelent összefoglaló közigazgatási munkájában már szükségesnek tartotta a vonatkozó törvényi szabályozás ismertetését kiegészíteni e segédszemélyzet bemutatásával. ${ }^{662}$

A járási személyzet részét képezték még a már bemutatott közbiztonsági közegek, amelyek mellett a vármegyék a szolgabírói hivatal fenntartása céljából tiszti szolgákat is rendeltek tervezeteikben. ${ }^{663} \mathrm{~A}$ többi törvényhatóság járási szervezetétől jelentős mértékben elütően járt el Alsó-Fehér vármegye, amely a szolgabírónak alárendelt segédszemélyzetként szervezte meg az útibiztos pozícióját is. ${ }^{664}$

A szolgabírói hivatal létrehozására irányuló tervezetek belügyminisztériumi megerösítése kapcsán megfigyelhető, hogy a miniszteri tanácsosok konzekvensen ragaszkodtak a törvény által meghatározott titulusok alkalmazásához. A főszolgabírói, alszolgabírói és esküdti elnevezéseket sikerrel iktatták ki a vármegyék tisztikarából. Az esküdtek esetében ez érthető, ugyanis ezzel is erősíteni kívánták az igazságszolgáltatás és a közigazgatás elválasztását. A főszolgabírák és az alszolgabírák elhagyása már nehezebben magyarázható, különösen, hogy, amint a fentiekből kiderült, ezzel az uralkodó gyakorlat megváltoztatására volt szükség. Ennek okaként az hozható fel, hogy a törvény egyszerủ és egyértelmü felelősségi viszonyokat kívánt teremteni a közigazgatásban, ${ }^{665}$ amit elősegített, ha a járás élén az egyszemélyi hivatalvezetést végző szolgabírák állnak, akiknek a felelőssége kiterjed a szolgabírói hivatalban dolgozókra. Ezzel magyarázható az esküdti tisztség megszüntetése is, mivel az esküdtek korábban a szolgabírákkal együttesen eljárva végezték tevékenységüket. Emellett pedig a vármegyei törvénykezési szervek megszüntetésével a szolgabíró is elveszítette ítélkezési hatásköreit, így az esküdtek bírótársi feladatkörei szükségtelenné váltak.

\footnotetext{
658 MNL BM K150 118. 22499/1871.

659 MNL BM K150 117. 32702/1871.; 28287/1871.; 28525/1871.; 118. 32051/1871.; 22336/1871.; $34064 / 1871 ; 30172 / 1871$.

660 MNL BM K150 118.26616/1871.; 33141/1871.

${ }_{661}$ MNL BM K150 118.31697/1871.

662 BonCZ 1876, 128e).

663 MNL BM K150 117. 17808/1871. - Fejér vármegye; 118. 23346/1871. - Alsó-Fehér vármegye; Minden bizonnyal több más törvényhatóság is hasonlóképpen járt el, csak tervezeteikben nem különítették el a szolgabírák mellé rendelendő tiszti szolgákat.

664 „Minden szolgabiró mellé egy irnok, egy utibiztos és egy a járás költségére felfogadandó szolga hozatik javaslatba” - MNL BM K150 118. 23346/1871.

665 KI V.k. 189.
} 
Szintén a felelősségi kérdések miatt volt jelentősége annak, hogy a szolgabírák legyenek a járás egyetlen választott tisztségviselöi, mivel a vármegyei tervezetekből kitűnik, hogy a törvényhatóságok a törvényhatósági bizottság által választott alszolgabíráknak vagy esküdteknek nagyobb legitimitást tulajdonítottak. Emiatt könnyebben alkalmazhatták volna őket önálló eljárási cselekmények esetében is. Ennek megakadályozása érdekében sem hagyhatták jóvá azt a megoldást, hogy a járási feladatok ellátásába a vármegye más választott tisztségviselöt is bevonhasson.

A minisztérium munkája hatékonyan megvalósította a járási szervezet egységesítését. A minisztériumi jogalkalmazás beemelte a szolgabírósegédet is a szolgabírák tehermentesítésére alkalmazható személyek közé, így a járási feladatok elvégzését a szolgabírák végezték a szolgabírósegéd, illetve a szolgabírói írnokok segítségével. A közbiztonsági személyzet esetében tapasztalható sokszínűség mutat rá érzékletesen arra, hogy miért volt szükséges a jogalkotó és a belügyminisztérium egységesítési törekvése.

A törvényhatóságok számára kérdéses volt, hogy az újjáalakított járási szervezetükben miképpen lesz lehetséges a szolgabírák helyettesítése. Békés vármegye ezzel is indokolta a tervezetének azon részét, hogy alszolgabírákat alkalmazott volna a szolgabírák mellé. ${ }^{666}$ Míg Hont vármegye az esküdti állomás létrehozása mellett érvelt ezzel ${ }^{667} \mathrm{~A}$ legcélszerübb, valamint a törvény szellemével leginkább összhangban lévő megoldást, amelyet minden bizonnyal végül a többi vármegye is követett, Csanád vármegye dolgozta ki, amely tervezete szerint a járás élén álló tisztviselő időszakos pótlását a másik járás szolgabírójának többletfeladatokkal való ellátásával kívánta megoldani. ${ }^{68}$

A belügyminisztérium munkájában az 1870:XLII. tc. végrehajtása kapcsán megnyilvánuló következetesség később kevésbé megfigyelhető. Abaúj vármegye ugyanis amiatt intézett feliratot 1872. június 14-én a belügyminisztériumhoz, hogy a belügyminiszter engedélyezze számára helyettes szolgabírák segédszemélyzetként való alkalmazását a szolgabírák mellé a községi törvény végrehajtásának idejére, akiket szintén szolgabíróként kívánt megnevezni. ${ }^{669} \mathrm{~A}$ törvényhatóság által kezdeményezett átalakítás igencsak ellentmondásosnak tünik azzal az egységesítési és egyértelmű felelősségi szabályokat célzó szándékkal, amire a belügyminisztérium a köztörvényhatósági törvény végrehajtásakor a szolgabírói hivatal kapcsán törekedett. A belügyminisztériumi tanácsos ennek ellenére Abaúj vármegye felterjesztését minden kifogás nélkül tudomásul vette. ${ }^{670}$

$\mathrm{Az}$ viszont egyértelműen kijelenthető, hogy a belügyminisztériumi munkálatok eredményeképpen a törvényhatóságok járási szervezete nagy lépést tett annak irányába, hogy a korábbi partikuláris, rendi igazgatási egységekből a polgári kor követelményeinek megfelelö, egységes közigazgatási szervezetté alakuljon át.

„A' községi rendezés gyorsabb keresztül vitele czéljából határozatilag minden szolgabiró mellé helyettes szolgabirákat is nevezett ugyan, - hanem ezen segéd személyzet csupán a' rendezés bevégzéséig ruháztatott fel szolgabirói czimmel, - de dijjtalanul határoztatván el azoknak alkalmazása, - ezen intézkedés sem a Megye sem az állam pénztárát legkissebbé sem fogja terhelni." - MNL BM K150 153. 18892/1872.

670 MNL BM K150 153. 18892/1872. 



\section{A SZOLGABÍRÁK JOGÁllásA \\ A KIEGYEZÉST KÖVETŐEN}

„A közadministratio épen ugy megkivánja a maga
tehetséges és munkabiró, szorgalmas tisztviselöit,
mint az igazság szolgáltatás; 's ettól is épen úgy
megvárható, miszerint minden erejét tehetségét,
hivatalos kötelességei teljesitésére forditsa.

Az 1870. évi köztörvényhatósági törvény volt az első olyan jogszabály, amely a területi közigazgatásra vonatkozó normaszöveg egységes kodifikálását valósította meg. A vármegyei tisztségviselők közszolgálati jogállását viszont továbbra sem szabályozta egységesen a törvény, hiszen az csupán a tisztviselők választásáról és a fegyelmi felelősségre vonásukról rendelkezett. A 19. században közszolgálati pragmatika névvel illették azon rendszerezett jogi normák összességét, amely magában foglalta a közszolgálati jogviszonyra, az államhivatalnokok jogaira és kötelességeire, a közszolgálat keletkezésére és megszűnésére vonatkozó szabályokat. ${ }^{672}$

Az 1870:XLII. tc. megalkotásakor különálló jogszabályok sem születtek még, amelyek a közhivatalnokok jogainak egy-egy szeletét tartalmazták volna. E fejezet az 1870:XLII. tc. végrehajtását mutatja be a törvény bevezetését követő évek belügyminisztériumi iratanyagának vizsgálatával a hangsúlyt a járást vezető tisztségviselőkre, a szolgabírákra vonatkozó közszolgálati szabályokra fektetve.

\subsection{A szolgabírói tisztség elnyerésének szabályai}

Csiky Kálmán és Boncz Ferenc, a 19. század második felének kiemelkedő közigazgatási szakírói a közhivatalnokok körét az államszolgálatban állókra és a törvényhatósági vagy községi szolgálatban állókra osztották. ${ }^{673}$ Keleti Ferenc ügyvéd, az államszolgálat jogi szabályozásának kutatója, akképpen határozta meg az államszolgálat fogalmát, hogy ennek olyan tevékenységnek kell lennie, amelyet a köztisztviselő az állam nevében, érdekében és megbízásából hajt végre. ${ }^{674} \mathrm{~A}$ közszolgálati jog hatálya alá azonban nemcsak a közhivatalnokok tartoztak, hanem a törvényhatóságok segéd- és kezelöszemélyzete is.

\footnotetext{
671 MNL BM K150 118. 22592/1871. - Bereg vármegye

672 Keleti 1886, 217.

673 Boncz 1876, 175.; Csiky 1888, 177-178.

674 Keleti $1886,2-3$.
} 
A fent ismertetett beosztás alapján a szolgabírák a törvényhatósági tisztségviselök közé sorolandók.

Az 1870:XLII. tc. 65. §-a szerint a tisztviselőket a törvényhatósági bizottság hat évre választotta a kijelölő választmány által meghatározott három személy közül. A köztörvényhatósági törvény részletes vitája során nagy figyelmet kapott a tisztségviselők választásáról szóló rendelkezés azon része, amelyben az országgyűlés meghatározta a választható tisztviselők kijelölésére jogosult szervet. Az eredeti javaslatban a főispán önálló kijelölési jogot kapott, amely szerint a belügyminiszter által kinevezett föispán volt jogosult a három jelölt megnevezésére. Közülük a törvényhatósági bizottság által legrátermettebbnek tartott tölthette be a vármegyei tisztséget. ${ }^{675}$

A központi bizottság azzal a változtatási javaslattal fordult a Képviselőházhoz, hogy ezt a szakaszt úgy módosítsák, hogy a jelöltek meghatározásának a jogát egy kijelölő választmányra bízzák. Ez a választmány a föispán elnöklete alatt a törvényhatósági bizottság által választott és a föispán által meghívott három-három tagból állt össze és a szavazatok egyenlősége esetén az elnök szavazata döntött. A kijelölő választmány is egy-egy pozícióra három jelöltet állíthatott. ${ }^{676} \mathrm{Az}$ ellenzék azonban nemtetszését fejezte ki a föispán elnöklete alatt müködő kijelölő választmány miatt, mivel az továbbra is a főispán befolyása alatt működhetett, és így ő érvényesíthette akaratát a tisztségviselők választása során. A Tisza Kálmán vezette ellenzék az ilyen főispáni visszaéléseket azzal kívánta meggátolni, hogy a kijelölő választmányban a törvényhatósági bizottság túlsúlyát biztosítja. Az országgyủlés azonban előterjesztéseiket leszavazta. ${ }^{677}$

A szolgabírói pozíció elnyerése körül más probléma is jelentkezett. Rajner Pál belügyminiszter az országgyűlési vita első napján, 1870. június 30-án felszólalásában úgy nyilatkozott, hogy a törvény szövegezése során kérdésként merült fel, hogy a járási tisztviselőket csak az illető járás választhassa, vagy inkább a központban a törvényhatósági bizottság kapjon-e erre jogosultságot. A szolgabírák megválasztása azonban a törvényhatósági bizottság hatáskörében maradt, mivel a belügyminiszter álláspontja szerint a kijelölésnél megfelelően biztosíthatóak a járási választópolgárok érdekei ${ }^{678} \mathrm{~A}$ törvény e rendelkezésénél érdemes figyelembe venni az 1870:XLII. tc. megszületése előtt a szolgabírói tisztség elnyerését szabályozó 1435. évi második dekrétum 2. cikkelyét. Ennek értelmében szintén a vármegye összes nemese volt jogosult a szolgabírák megválasztására. Ebből következik, hogy az országgyűlés a történeti hagyományokhoz hűen szabályozta a szolgabírák választását, amely abból is érzékelhető, hogy az országgyűlési képviselők sem vitatták a szabályozás e módjának a létjogosultságát.

A polgári közigazgatás kiépítése során a magyar országgyülés így ismételten visszatért a rendi korszak hagyományait érvényesítő elvhez, elvetve a neoabszolutizmus idején nóvumként alkalmazott kinevezés elvét. Annak ellenére, hogy a választás elvének érvényesítése nem váltott ki vitát a képviselők körében a törvényhozás során, ez a megoldás

\footnotetext{
KI 1869. V.k. 46.

KI 1869. VI.k. 170.

KN 1869. X. k. 285-290.

KN 1869. IX. k. 46.
} 
sem maradt visszhang nélkül. Kecskeméthy Aurél vitatta ugyanis 1867-ben megjelent munkájában a választás elvének létjogosultságát az újonnan kiépítendő modern államszervezetben. A közigazgatási tisztviselőknél miniszteri jóváhagyással még elfogadhatónak tartotta a választást, a bírák esetében azonban teljes mértékben mellőzni kívánta azt. A bírák esetében meg is valósult az általa javasolt szisztéma az 1869:IV. tc. elfogadásának köszönhetően. Soraiból azonban kitűnik, hogy a választási szisztémát mindkét esetben anakronizmusnak tartotta, így a közigazgatási tisztségviselők esetében is inkább mellőzné ezt a megoldást. Álláspontja szerint a hatáskörük ellátása során azonos mértékben végeztek állami és törvényhatósági feladatokat a megyei tisztségviselők, így nem igazságos, ha csupán a megyék aktusa által nyeri el a tisztségét az adott tisztviselő. Emellett aggályosnak tartotta, hogy az adott személyeket gyakran nem, vagy csak csekély mértékben ismerték a választásra jogosultak, amely így nehezítette azt, hogy megfelelő döntést hozzanak. Kiemelte, hogy a kinevezési rendszernél sem feltétlenül ismerné az adott miniszter a kinevezendő személyt, viszont döntéséért felelősséggel tartozott, ami az önkormányzati szerv általi választás esetében hiányozna. Visszásságként jelölte meg a helyi választással kapcsolatban, hogy ezáltal a tisztviselő függetlensége megkérdőjeleződik és a korteskedés fontos szerepet tölthet be egy-egy tisztségről való döntés során. ${ }^{679}$

A szolgabíró választásának további vitatott pontja volt a hat évre való megválasztása. A korábbi szabályozás szerint ugyanis az 1723:56. tc. alapján a tisztviselők megbízatása három évre szólt, a törvény azonban ezt hat évre módosította. Az indoklás szerint ennek oka az volt, hogy a közigazgatási feladatok ellátása tapasztalatot és ügyismeretet kíván, amelyet az e tisztségeket betöltők gyors változása nem tud biztosítani. Emellett a törvény indoklásában annak a reménynek is hangot adtak, hogy a hosszabb távra szóló megbízás vonzóbb lesz a magasan kvalifikált személyek számára is. ${ }^{600} \mathrm{~A}$ szolgabírák esetében ez egy előremutató változásnak tekinthető, de a meghatározott időtartamú szolgálat helyett a hazai szakirodalomban már korábban felmerült az élethossziglan tartó tisztviselői modell bevezetésének szükségessége.

Palugyay Imre művében már a rendi korszakban elvégezte a két modell összevetését, mindkettőnek kiemelve erényeit. A nem élethosszig tartó hivatalviselés legfőbb előnyének azt tartotta, hogy így az alkalmatlan tisztségviselők igen könnyen eltávolíthatókká válnak. Az élethossziglan tartó hivatalviselés mellett szólt az az érv, hogy a szakértelmet igénylő tisztségek esetében szükséges, hogy állandó hivatalnokok lássák el a feladatokat. Csupán így tartotta elérhetőnek, hogy a megfelelő szakértelmet és gyakorlatot szerezhessenek a közigazgatási közegek. Emellett állandó gondot okozott, hogy a hivatal átadása és átvétele idején nem látták el a tisztségviselők feladataikat és ritkán történt „zökkenőmentesen” az iratok átadása, mivel gyakran hiányzott az iratok megfelelő leltára. ${ }^{681}$ A szolgabírói tisztség is az alapos szakértelmet igénylő hivatalok közé tartozott. Emiatt Palugyay felvetése megfontolandó lett volna e vármegyei tisztség esetében is.

\footnotetext{
679 KeCSKemÉthy 1867, 68-76.

680 KI 1869. V. k. 198.

681 Palugyay $1844 \mathrm{~b}, 1-7$.
} 


\subsection{A szolgabírák javadalmazása az 1870: XLII. tc. alapján ${ }^{682}$}

A szolgabírákkal kapcsolatban érdemes azt is figyelembe venni, hogy miképpen alakult a tisztséget betöltők javadalmazása. A szolgabírák fizetésének meghatározása a vármegyék hatásköréhez tartozott, mert a jogalkotó ezt is az 1870:XLII. tc. 91.§c) alapján az új közigazgatási szervezet kidolgozására jogosult városi és területi törvényhatóságok hatáskörébe utalta. ${ }^{683} \mathrm{~A}$ rendi korhoz hasonlóan ennek köszönhetően a különböző méretü és anyagi hátterű vármegyékben eltérő jövedelmeket állapítottak meg a szolgabírák számára, így a neoabszolutizmusban kialakított teljes egységesség a fizetések terén megszünt.

A belügyminisztérium által megerősített törvényhatósági felterjesztésekben vizsgáltam a szolgabírák számára megállapított fizetéseket. ${ }^{684} \mathrm{~A}$ szolgabírói fizetéseket a törvényhatóságok igen tág keretek között határozták meg. A legalacsonyabb tiszti fizetést Aranyosszék szabta meg, mindössze $500 \mathrm{Ft}$ éves fizetést biztosított a szolgabírái számára. ${ }^{685} \mathrm{Ez}$ annak fényében nem meglepő, hogy a szék lakosságszáma a többi törvényhatósághoz viszonyítva kirívóan alacsony volt. Az új törvényi szabályozás értelmében alacsony költségvetéssel számolhattak, mivel az a törvényhatóság adóbevételéhez igazodott. A közigazgatás fenntartására fordítható várható adóbevétele mindössze az 1/5-e volt az 1870. évi költségvetés alapján a törvényhatóság közigazgatási működési költségeinek. ${ }^{686}$

A vizsgált vármegyék közül az erdélyiekben, Kövár vidéken (ekkor már az anyaországhoz csatolva), Zaránd és Hont vármegyében volt a szolgabírák éves fizetése $1000 \mathrm{Ft}$ alatt. ${ }^{67}$ Küküllő vármegye viszont a második, módosított tervezetében már $1100 \mathrm{Ft}$-ra emelte a szolgabírák javadalmazását a korábbi $900 \mathrm{Ft}$-ról. ${ }^{688} \mathrm{~A}$ többi vármegye mind legalább 1000 Ft-ban határozta meg szolgabíráinak fizetését. ${ }^{689}$ Békés (1 $\left.500 \mathrm{Ft}\right)$, Csongrád,

${ }^{682}$ A vármegyei tisztviselők keresményére a fizetés és a javadalmazás terminológiát alkalmazom, amely összhangban van a levéltári források, a korabeli irodalom és az 1870:XLII. tc. fogalomhasználatával. Az illetmény kifejezést a korszakban nem ebben az értelemben használták. BonCz 1876, 227.; FÉsüs 1880, 429-430.

VARga 2010b, 119-120.; VARga 2002, 60.; Ruszoly 1982, 55-61.; STIPTA 1992b, 482-483.

MNL BM K150 117. 17731/1871. - Arad vármegye; 20171/1871. - Aranyosszék; 21799/1871. - Bars vármegye; 21161/1871.; 31913/1871. - Békés vármegye; 17803/1871. - Csanád vármegye; 21068/1871. - Csongrád vármegye; 21272/1871. - Doboka vármegye; 17808/1871. - Fejér vármegye; 22026/1871. - Felső-Fehér vármegye; 21800/1871. - Fogaras vidék; 31267/1871. - Zala vármegye; 118. cs. 31726/1871. - Alsó-Fehér vármegye; 22592/1871. - Bereg vármegye; 23816/1871. - Gömör és Kis-Hont vármegye; 28726/1871. - Hont vármegye; 22499/1871. - Kővár vidék; 32644/1871. Szabolcs vármegye; 22336/1871. - Veszprém vármegye. -Felsö-Fehér vármegye, 21800/1871. - Fogaras vidék, 118. 31726/1871. - Alsó-Fehér vármegye; 28726/1871. - Hont vármegye; 22499/1871. - Kővár vidék; 25309/1871. - Küküllő vármegye; 25636/1871. - Zaránd vármegye. 
Temes és Zala $(1400 \mathrm{Ft})$ vármegyében rendelkeztek a legmagasabb keresménnyel a járást vezető tisztviselők ${ }^{690}$ Ez föként annak köszönhető, hogy a vármegyék az 1870:XLII. tc. végrehajtását megelőző tiszti fizetések alapján állapították meg az egyes tisztviselők fizetését és a többi vizsgált vármegyében jelentősen magasabbak voltak a keresetek, mint az erdélyi vármegyékben. Ezektől az összegektől érdemi eltérések nem figyelhetőek meg, a fizetések minimális növelése tapasztalható csupán néhány vármegyében. Ehhez azonban érdemes hozzátenni, hogy a korábban fö- és alszolgabírákkal is rendelkező vármegyék egy része a régi fö- és alszolgabírói fizetés közötti összeget biztosított csak az új szervezetben a szolgabíráknak.

Ebből a szempontból Hont vármegye közgyülésének szervezési munkálata mutatott a többiektől eltérő képet. 1871-ben a vármegye főszolgabíráinak éves fizetése $1200 \mathrm{Ft}$ volt, míg az alszolgabíráknak 900 Ft. Ehhez képest az újonnan létrehozandó közigazgatási szervezet szolgabírái mindössze 800 Ft-os éves javadalmazással számolhattak, ami jelentős fizetéscsökkentést eredményezett. ${ }^{691} \mathrm{~A}$ vármegyei bizottmány meg is jegyezte a belügyminisztériumnak küldött válaszában, hogy „Hont megye egy az ország azon megyék [sic!] közül, melyek a szükségesnél kisebb fizetésekkel ellátni határozta tisztviselöit." ${ }^{692}$ Ehhez hasonlóan Kővár vidék is 1200 Ft-ról csökkentette a járást vezető tisztviselőinek fizetését $800 \mathrm{Ft}$-ra. ${ }^{693}$

Ugyanez tapasztalható Aranyosszék esetében is, ahol, mint említettem, a szék közönsége a korábbi $700 \mathrm{Ft}$-os fizetést $500 \mathrm{Ft}$-ra csökkentette. ${ }^{694}$ Hont vármegye és Kővár vidék esetében hasonló probléma merült fel, mint Aranyosszéknél, az 1870. év közigazgatási kiadásai a várható adóbevételek másfélszeresére rúgtak, így a közgyűlés igyekezett csökkenteni a kiadásokat. Érdemes azonban megjegyezni, hogy nem csupán ennél a két vármegyénél mutatkozott jelentős eltérés az 1870. évi közigazgatási kiadások és az előirányzott adóbevétel között, de a többi törvényhatóság ezt figyelmen kívül hagyta.

A tiszti fizetések meghatározásakor az egyes vármegyék számára a legfőbb korlátot a saját teherbíró képességük jelentette, mivel az 1870:XLII. tc. értelmében a törvényhatóságok önkormányzati jogához tartozott a közigazgatás költségeinek meghatározása és annak fedezetéről való gondoskodás. A törvényhatóságok közigazgatási költségeinek a saját házipénztárukból való fedezése azonban sosem valósulhatott meg, így az a felemás helyzet állt elö, hogy a törvényhatóság által szabadon meghatározott tisztségviselői fizetéseket az államkassza fedezte. ${ }^{69}$

17808/1871. - Fejér vármegye; 22226/1871. - Krassó vármegye; 20826/1871. - Sáros vármegye; 21797/1871. - Szepes vármegye; 21949/1871. - Temes vármegye; 20991/1871. - Trencsén vármegye; 31267/1871. - Zala vármegye; 118. 22592/1871. - Bereg vármegye; 32051/1871. - Gömör és KisHont vármegye; 30274/1871. - Komárom vármegye; 22691/1871. - Nógrád vármegye; 32644/1871. - Szabolcs vármegye; 22336/1871. - Veszprém vármegye.

692 MNL BM K150 118.31986/1871.

${ }_{693}$ MNL BM K150 118. 22499/1871.

${ }_{694}$ MNL BM K150 117.20171/1871.

695 Stipta 1995b, 156-159. 
Az egyes tisztviselők fizetésének összehasonlításával azt vizsgálom, hogy a vármegyék a szolgabírákat hol helyezték el az adminisztratív közegek „rangsorában”. Az egyértelműen megállapítható, hogy minden vármegyében a legjobban honorált tisztviselő az alispán (Aranyosszék esetében az alkirálybíró, Fogaras vidéknél és Kővár vidéknél pedig a vidéki alkapitány) volt, mellette pedig kiemelkedő fizetéssel rendelkezett még az árvaszéki elnök és a legtöbb vármegyében a főjegyző is. ${ }^{696} \mathrm{~A}$ föjegyző kiemelkedő elsimertségét mutatja, hogy Szepes vármegyében ezzel a tisztséggel vonták össze az árvaszéki elnök pozícióját. ${ }^{67}$ A vármegyék jellemzően az említetteknél alacsonyabb, közel azonos szintű javadalmazást biztosítottak a pénztárnoknak, a számvevőnek, a tiszti ügyésznek és a szolgabíráknak. ${ }^{698} \mathrm{~A}$ föorvosnak, az állatorvosnak és a levéltárnoknak a fizetése szinte kivétel nélkül alacsonyabb volt a szolgabírákénál. A leginkább ingadozó a fömérnök keresménye volt, néhány esetben a vármegye legjobban honorált tisztségei közé tartozott, míg más törvényhatóságokban a legalacsonyabb fizetéssel rendelkező választott tisztségviselők közé sorolták. Az egyes vármegyékben viszont előfordultak ettől igen eltérően megállapított javadalmazások. Gömör és Kis-Hont vármegye állandó bizottmánya tervezetében szolgabírái (tévesen még itt a föszolgabíró elnevezést használták) számára a főjegyzővel és az árvaszéki elnökkel megegyező javadalmazást biztosítottak, csupán az alispán fizetése volt jóval magasabb az övéknél. ${ }^{69}$ Aranyosszék esetében az alispán és a föjegyző utáni harmadik legmagasabb javadalmazás a szolgabíróé, amely még az árvaszéki bíróénál (a szék az elnök helyett ezt a kifejezést használta) is magasabb volt. ${ }^{700}$ Nógrád vármegyében ehhez hasonlóan a közgyưlés az alispán, a föjegyző és a tiszti ügyész után a többi tisztviselőt messze megelőző, az árvaszéki elnökkel azonos fizetést állapított meg a szolgabíráknak. ${ }^{701}$ Sáros vármegye pedig az alispán után a föjegyzőnek, a tiszti ügyésznek, az árvaszéki elnöknek és a föszolgabíráknak azonos mértékủ járandóságot juttatott, bár a közülük egyedül a föszolgabíráknak nem nyújtott szállásbérek némiképp árnyalják a képet. ${ }^{702} \mathrm{~A}$ belügyminisztériumi felhívás következtében egységesített szolgabírói megnevezést követően az 1100 Ft-os

696 - Bars vármegye; 21161/1871.; 31913/1871. - Békés vármegye; 17803/1871. - Csanád vármegye; 21068/1871. - Csongrád vármegye; 21272/1871. - Doboka vármegye; 17808/1871. - Fejér vármegye; 22026/1871. - Felső-Fehér vármegye; 21800/1871. - Fogaras vidék; 22226/1871. - Krassó vármegye; 20826/1871. - Sáros vármegye; 21797/1871. - Szepes vármegye; 21949/1871. - Temes vármegye; 20991/1871. - Trencsén vármegye; 31267/1871.-Zala vármegye; 118. 31726/1871. - Alsó-Fehér vármegye; 22592/1871. - Bereg vármegye; 28726/1871. - Hont vármegye; 30274/1871. - Komárom vármegye; 22499/1871. - Kövár vidék; 25309/1871. - Küküllő vármegye; 32644/1871. - Szabolcs vármegye; 22336/1871. - Veszprém vármegye; 25636/1871. - Zaránd vármegye. 
fizetésükkel továbbra is a kiemelt fizetést kapó tisztviselők között maradtak a szolgabírák Sáros vármegyében. ${ }^{703}$ Csongrád vármegye az alispán és a főjegyző fizetése utáni legmagasabb pénzösszeget az árvaszéki elnök és a mérnök mellett ugyanígy a szolgabírái számára állapította meg. ${ }^{704}$ Bars vármegye, Doboka vármegye és Zala vármegye szintén kiemelte a szolgabírákat és az árvaszéki elnök, az alispán és a főjegyző után számukra biztosították a legmagasabb javadalmazást. ${ }^{705}$ Kükülló vármegyében a szolgabírák szintén a kiemelten premizált tisztviselők közé tartoztak, különösen a második, módosított tervezetben előterjesztett 1100 Ft-os éves fizetéssel, ugyanis csak az alispán, a föjegyzö, az árvaszéki elnök és a tiszti ügyész javadalmazása múlta ezt felül. ${ }^{706}$ Hont vármegye viszont az alszámvevővel, a főorvossal és a levéltárnokkal megegyezően honorálta szolgabíráit, így az összes választott tisztviselő fizetése magasabb volt ebben a vármegyében, mint a járás adminisztrációjaért felelős hivatalnokoknak. ${ }^{707}$ Zaránd vármegyében a szolgabírák számára megállapított javadalmazás szintén a mérsékeltebbek közé tartozott, ugyanis az alispán és a föjegyző kiemelkedő fizetése után komoly „szakadék” mutatkozott, majd a pénztárnok 800 Ft-os járandósága után az aljegyző, a főorvos, a számvevő és a szolgabírák következtek 700 Ft-tal, bár ebben az esetben is javította a szolgabírák helyzetét, hogy a főorvos mellett csupán nekik járt állandó útiátalány. ${ }^{708}$

Érdemes megvizsgálni a vármegyék esetében a tiszti fizetésekhez füzött indoklásokat is. Ezzel a lehetőséggel nem mindegyik vármegye élt. Általában azzal magyarázták a javadalmazások mértékét, hogy más hasonló foglalkozásúak (igazságügyi, pénzügyi, hadügyi, bányászati tisztviselők, az iparban és a kereskedelemben dolgozók) bérével vetették össze azokat. ${ }^{709}$ Krassó vármegye pedig az állami tisztviselők fizetésének mértékével magyarázta az általa megszabott javadalmazásokat. ${ }^{710} \mathrm{~A}$ leggyakrabban a bírák fizetéseivel hasonlították össze a törvényhatósági tisztviselők keresetét. ${ }^{71} \mathrm{~A}$ legnagyobb bérfeszültséget nyilvánvalóan az okozta, hogy a legtöbb vármegye az újonnan felállított országos bírói szervezet tagjainak állami fizetésénél csak alacsonyabb juttatásokat tudott meghatározni. Csanád vármegye kiemelte tervezetében, hogy a szolgabírák számára nem a járásbíró, hanem csupán az aljárásbíró fizetését kívánják juttatni. ${ }^{712}$ Számos vármegye meg

\footnotetext{
703 MNL BM K150 117.27062/1871.

704 MNL BM K150 117.27282/1871.

705 MNL BM K150 117.21799/1871.; 21272/1871.; 21798/1871.

706 MNL BM K150 118.25309/1871.; 31404/1871.

707 MNL BM K150 118. 28726/1871.

708 MNL BM K150 118. 25636/1871.

709 MNL BM K150 117.21068/1871. - Csongrád vármegye; 20171/1871. - Aranyosszék; 17808/1871. - Fejér vármegye.

710 „Ugyanis a tisztviselói fizetések megállapitásánál zsinórmértékül vettük az állam tisztviselókre nézve megszabott fizetéseket, mert köztudomásu hogy az államnál rosszabbul nem fizeti senki tisztviselöit, kivéve épen a megyét." - MNL BM K150 117.32636/1871.

711 MNL BM K150 117.21799/1871.; 28287/1871. - Bars vármegye; 21161/1871. - Békés vármegye; 17808/1871. - Fejér vármegye; 21272/1871. - Doboka vármegye; 21797/1871. - Szepes vármegye; 21949/1871. - Temes vármegye; 118. 22592/1871. - Bereg vármegye; 23816/1871. - Gömör és KisHont vármegye; 25636/1871. - Zaránd vármegye.

712 MNL BM K150 117. 17803/1871.
} 
is jegyezte, a bírák fizetését annak ellenére szabta meg magasabban az országgyuulés, hogy kinevezett tisztviselőként nem fenyegette őket olyan mértékben a hivatal elvesztése, mint a választás alá eső törvényhatósági hivatalnokokat. ${ }^{713} \mathrm{~A}$ vármegyék attól tartottak, hogy a kedvezőtlenebb feltételek miatt a tehetséges jelöltek számára nem lesz kellően vonzó a megyei adminisztráció feladatainak ellátása. ${ }^{714}$ Küküllő vármegye figyelmeztette is a belügyminisztériumot, hogy a fizetések további csökkentésének következtében kizárólag a vagyonos osztály tagjainak privilégiumává válna a vármegyei hivatalok betöltése. ${ }^{715}$

A tervezetek elkészítői emellett gyakran felvillantották annak a lehetőségét, hogy a túlságosan alacsonyan meghatározott fizetések arra kényszeríthetik a tisztség betöltőit, hogy más módon biztosítsák a megfelelö jövedelmüket. ${ }^{716}$ Ezzel arra figyelmeztették a belügyminisztériumot, hogy a nem megfelelő fizetések a hivatali vesztegetéseket fogják elösegíteni. Csongrád, Fejér és Sáros vármegye a törvényhatóság magas megélhetési költségeivel magyarázta a fizetéseket. ${ }^{717}$ Arad vármegye ennél jóval általánosabban indokolta a szolgabírói fizetéseket, mivel a takarékosság elveit, az egyes tisztviselők munkakörét és az adott kor követelményeit vették figyelembe. ${ }^{718}$ Fejér és Sáros vármegye a takarékossággal, ${ }^{719}$ míg Alsó-Fehér, Temes és Trencsén vármegye pedig a kor igényeivel indokolta Aradhoz hasonlóan a fizetések meghatározását. ${ }^{720}$ Kővár vidék emellett azzal érvelt, hogy a tisztviselőkre súlyos felelősség hárul a közigazgatásra vonatkozó új rendelkezések alapján. ${ }^{721}$

Több törvényhatóság is kiemelte, hogy a közigazgatás immáron teljes embert kíván, így a megyei hivatalnokok sem fognak tudni hivatalos elfoglaltságaik mellett egyéb jövedelemhez jutni, emiatt is szükséges magasabb fizetéseket megszabni. ${ }^{722}$ Trencsén vármegye külön megjegyezte, hogy ezáltal „a régi kor hagyományait” (nobile officium) kell maguk

713 „[A] leendö közigazgatási tisztviselök fizetését nem hoztuk arányba a birósági személyzet fizetésével sem, holott a birósági személyzet jövője biztositott párt és politikai hullámoktól nem függö: míg a közigazgatási tisztviselöleggyakrabban nem kellemes hivatali légkörben mozog, - szembe kell szállnia megrögzött elöitéletekkel szavart fogalmakkal, s leghübb odaadóbb müködése dacára nemcsak méltánylatban nem részesül, de annak van kitéve, hogy a választások áramlatában szolgálati dijául hivatali megfosztást aratja." - MNL BM K150 117.21799/1871. - Bars vármegye; 32636/1871. - Krassó vármegye; 21797/1871. - Szepes vármegye; 21949/1871. - Temes vármegye; 118. 22499/1871. - Kövár vidék.

714 „[T]iszteséges fizetés nélkül a legjobb eröket koczkáztatjuk, 's méltán tartani lehet töle, miszerint a kiválóbb egyéniségek tehetségeiknek más munkakört igyekvendenek inkább biztositani." - MNL BM K150 118. 23816/1871. - Gömör és Kis-Hont vármegye; 117. 21068/1871. - Csongrád vármegye; 27062/1871. - Sáros vármegye; 21797/1871. - Szepes vármegye; 118. 22499/1871. - Kővár vidék; 31404/1871. Küküllö vármegye.

715 MNL BM K150 118.31404/1871.

716 MNL BM K150 117.21068/1871. - Csongrád vármegye; 20171/1871. - Aranyosszék; 118.31337/1871. - Hajdú kerület.

717 „Tekintetbe kellett venni a közönségnek, hogy megyénkben a lakás, élelmiszerek szerfelett drágák, a napszám az amerikaival egyenlö; sö́t néh a magasabb lévén, bérkövetelését a cseléd is ehhez arányositja." - MNL BM K150 117.21068/1871.; 27062/1871.; 117. 17808/1871. - Fejér vármegye.

718 MNL BM K150 117.32702/1871.

719 MNL BM K150 117. 17808/1871.; 20826/1871.

720 MNL BM K150 118.31726/1871.; 117.21949/1871.; 28525/1871.

721 MNL BM K150 118.22499/1871.

722 MNL BM K150 117.22226/1871.; 32636/1871. - Krassó vármegye; 28525/1871. - Trencsén vármegye; 118. 22592/1871. - Bereg vármegye; 22499/1871. - Kővár vidék; 25636/1871. - Zaránd vármegye; 
mögött hagyniuk. ${ }^{723}$ Ezen állásponttal egyetértett Szepes vármegye is tervezetében. ${ }^{724}$ Sáros vármegye azt is rögzítette, hogy a vármegyei tisztviselők számára megtiltja a magánfelek képviseletét a bíróságok vagy más hivatalos közegek előtt, amely alól csupán a gyám- és gondoksági ügyek képezhettek kivételt. ${ }^{725}$ Szepes vármegye, Gömör és Kis-Hont vármegye, Bereg vármegye és Kővár vidék közgyủlései megjegyezték, hogy a közigazgatási tisztviselők állami feladatokat is ellátnak, így a központi kormányzatnak is érdeke, hogy a feladatokat szakképzett hivatalnokok végezzék, amelyre csak megfelelö fizetések mellett nyílik lehetőség. ${ }^{726}$ Fejér vármegye a tiszti fizetések meghatározásánál az 1861. évben a vármegyék helyreállítását követően megszabott juttatásokből indult ki. ${ }^{727}$

A vármegyék egy része a fizetésen kívül egyéb juttatásokat is igyekezett nyújtani a tisztviselői számára. A leggyakoribb juttatások a szolgabírák esetében az útiátalány volt, ami érthető annak tudatában, hogy a járást vezető tisztségviselők irányába elvárás volt, hogy meghatározott időközönként látogassák meg a járásukba tartozó községeket. Szepes és Komárom vármegye nyújtotta a legmagasabb összegü „fuvarilletményt”, mivel 400 Ft-ot kaptak erre évente a szolgabíráik. ${ }^{728}$ Fejér, Bereg és Szabolcs vármegye az útiátalány nagyságát 300 Ft-ban szabta meg, ${ }^{729}$ míg Bars, Békés, Csanád, Krassó, Trencsén, Veszprém és Zaránd vármegye $200 \mathrm{Ft}-\mathrm{ban} .{ }^{730}$ Gömör és Kis-Hont vármegye első tervezetében szintén 300 Ft-ban határozta meg az útiátalány nagyságát, de ezt második tervezetében 100 Ft-ra csökkentette. ${ }^{731}$

Békés, Csanád, Trencsén és Zala vármegyék hozzájárultak a szolgabíráik lakhatásához is. Csanád és Békés vármegye természetben biztosított lakást a járást vezető tisztviselőknek. ${ }^{732} \mathrm{Ez}$ célszerü volt, mivel így egyúttal hivatali helyiséget is nyújtottak a számukra. Zala vármegyének erre viszont csak három szolgabíró esetében volt lehetősége, így a

„A közgyülés által megállapitott fizetésen kivül, semmi más cimen illetöséget [sic!], járandóságot maga, és hivatala részére sem nem követelhet, sem be nem vehet." - 117. 21272/1871. - Doboka vármegye.

723 MNL BM K150 117.28525/1871.

724 „Épen ezen okoknál fogva, az úgy nevezett nobile officium a jelenlegi állam kormányzati viszonyok között nem egyéb mint üres szólam, mert akkor midön a munka bármely nem oly tetemes értéket képvisel, nem lehet értelme a tiszti fizetések csekély voltának oly hivatali állomásoknál, melyek mint feljebb mondatott az illetô tisztviselö egész idejét és tehetségét igénybe veszik, ső́t minden más keresettól teljesen elzárják." - MNL BM K150 117.21797/1871.

725 MNL BM K150 117.20826/1871.

726 MNL BM K150 117-21797/1871. - Szepes vármegye; 118. 23816/1871.; 22499/1871.; „Különben is a'megyei közigazgatási tisztviselök, nemcsak a megyei érdekeknek elömozditói lévén hanem elsö sorban az államéi is, a' mennyiben katona állitás adó és több más illy nemü kötelességekkel elfoglaltatnék, à melyek igénylik hogy azoknak eszközlésére szakképes egyének alkalmaztassanak, 's a' fizetés lejebb szálitása által az élhetési mód ne lehetetlenitessék." - 27001/1871. - Bereg vármegye.

727 MNL BM K150 117. 17808/1871.

728 MNL BM K150 117.21797/1871.; 118.30274/1871.

729 MNL BM K150 117.17808/1871. - Fejér vármegye; 118.22592/1871. - Bereg vármegye; 32644/1871. - Szabolcs vármegye.

730 MNL BM K150 117. 21799/1871.; 31913/1871.; 17803/1871.; 22226/1871.; 20991/1871.; 118. 22336/1871.; 25636/1871.

731 MNL BM K150 118. 23816/1871.; 32051/1871.

732 MNL BM K150 117. 17803/1871.; 117.31913/1871. 
többit 200 Ft szálláspénzzel látta el. ${ }^{733}$ Nógrád vármegye viszont csak a balassagyarmati járás szolgabírójának tudott lakhatást biztosítani, így a többieknek szintén $200 \mathrm{Ft}$-tal járult hozzá az elszállásolásához. ${ }^{734}$ Trencsén vármegye is $200 \mathrm{Ft}$ „lakbérrel” javadalmazta szolgabíráit, ${ }^{735}$ míg Krassó vármegye e jogcímen 150 Ft-tal egészítette ki a szolgabírák fizetéseit. ${ }^{736}$ Alsó-Fehér vármegye teljesen más jellegű fizetésen felüli juttatást adott a szolgabíráinak, ugyanis a fizetésén felül $100 \mathrm{Ft}$ szolgatartási átalányt nyújtott. ${ }^{737}$ Temes vármegye $200 \mathrm{Ft}$, Krassó vármegye $60 \mathrm{Ft}$, míg Szepes vármegye 50 Ft irodai átalányt is biztosított a járást vezető tisztviselőknek. ${ }^{738}$

A szolgabírák javadalmazásán kívül érdemes összehasonlítani az egyes vármegyék szolgabírósegédeinek és szolgabírói írnokainak fizetését is. A szolgabírósegédek fizetése természetesen alacsonyabb volt, mint a szolgabíráké. Gömör és Kis-Hont, valamint Komárom vármegye 800 Ft-ban, Arad vármegye 700 Ft-ban, Trencsén, Hont és Veszprém vármegye pedig mindössze $600 \mathrm{Ft}$-ban szabta meg ennek mértékét. ${ }^{739}$ Komárom $(300 \mathrm{Ft})$, Veszprém $(200 \mathrm{Ft})$ és Gömör és Kis-Hont vármegye $(100 \mathrm{Ft})$ azzal javította a helyzetüket, hogy útiátalányt is nyújtott számukra. ${ }^{740}$ Trencsén vármegye $(100 \mathrm{Ft})$ pedig lakbérrel látta el őket. ${ }^{741} \mathrm{Az}$ írnokok fizetésését jóval kisebb összegben határozták meg, mint a szolgabírákét vagy a szolgabírósegédekét. Zala és Bereg vármegye kivételével minden vizsgált vármegyében a járást vezető tisztségviselő javadalmazásának a felénél kevesebb lett a szolgabírói írnok fizetése. Az írnoki javadalmazást a legtöbb vármegye évi 400 vagy $500 \mathrm{Ft}$ körül szabta meg. ${ }^{722} \mathrm{~A}$ legalacsonyabb pénzösszeget a szolgabírákhoz hasonlóan Aranyosszék, Zaránd vármegye $(200 \mathrm{Ft})$, valamint Felső-Fehér vármegye $(300 \mathrm{Ft})$ írnokai keresték, ${ }^{743}$ míg a legmagasabb fizetéseket Zala $(800 \mathrm{Ft})$, Csongrád (700 Ft, de csak az első rendủek esetében) és Bereg $(600 \mathrm{Ft})$ vármegye adta szolgabírói írnokainak. ${ }^{744}$ Trencsén vármegye viszont annak ellenére, hogy viszonylag magas fizetést biztosított a szolgabíráknak szolgabírói írnokai közül nyolcnak csupán 300 Ft mértékü

733 MNL BM K150 117.21798/1871.

734 MNL BM K150 118. 22691/1871.

735 MNL BM K150 117.20991/1871.

736 MNL BM K150 117.22226/1871.

737 MNL BM K150 118.31726/1871.

738 MNL BM K150 117.21949/1871.; 22226/1871.; 21797/1871.

739 MNL BM K150 118.32051/1871.; 30274/1871.; 117.32702/1871.; 20991/1871.; 118. 28726/1871.; $22336 / 1871$

740 MNL BM K150 118. 30274/1871.; 22336/1871.; 32051/1871.

741 MNL BM K150 117.20991/1871.

742 MNL BM K150 117. 32702/1871. - Arad vármegye; 21799/1871. - Bars vármegye; 31913/1871. - Békés vármegye; 17803/1871. - Csanád vármegye; 27282/1871. - Csongrád vármegye (a második rendű esetében); 21272/1871. - Doboka vármegye; 17808/1871. - Fejér vármegye; 21800/1871. - Fogaras vidék; 22226/1871. - Krassó vármegye; 20826/1871. - Sáros vármegye; 21797/1871. Szepes vármegye; 20991/1871. - Trencsén vármegye (egy kiemelt írnok); 118. 31726/1871. - AlsóFehér vármegye; 32051/1871. - Gömör és Kis-Hont vármegye; 22326/1871. - Komárom vármegye; 22499/1871. - Kővár vidék; 25309/1871. - Küküllő vármegye; 22691/1871. - Nógrád vármegye; 22336/1871. - Veszprém vármegye.

743 MNL BM K150 117.20171/1871.; 22026/1871. 118.25636/1871.

744 MNL BM K150 117.21798/1871. - Zala vármegye; 27282/1871.; 118. 22592/1871. - Bereg vármegye. 
fizetést tervezett. ${ }^{74}$ Fejér vármegye $50 \mathrm{Ft},{ }^{746}$ míg Gömör és Kis-Hont vármegye pedig $100 \mathrm{Ft}$ nagyságú lakbért is biztosított szolgabírói írnokai számára. ${ }^{747}$

A fizetések értékének meghatározásához jó viszonyítási alapot nyújt, hogy Hajdú kerület arra az álláspontra helyezkedett 1871-ben alkotott tervezetében, hogy 300-400 Ft évi fizetés egy egyedülálló hivatalnok létfenntartására sem elegendő, nemhogy egy családos ember számára. ${ }^{748}$

A szolgabírák a fizetésük mellett napidíjra és előfogati díjra is igényt tarthattak, amelyeket egységesen útiátalánynak neveztek. A közigazgatási tisztviselőknek járó napidijakat a belügyminisztérium a kiegyezést követően 1868. október 5-én a 19026/1868. sz. alatt kelt rendeletében az egész ország területére nézve egységesen szabályozta. A belügyminisztérium rendeletében két korábbi napidíjakkal kapcsolatos jogszabályra hivatkozott: az 1862. április 2 -án 16823. sz. alatt kelt helytartótanácsi rendeletre és egy még korábbira, az 1825. évi 28696. sz. alatt kiadott udvari rendeletre. ${ }^{749}$ A napidíjakat meghatározó szabályzattal kapcsolatos kérdéseket Máramaros vármegye felterjesztése kapcsán válaszolta meg a központi kormányzat.

A megjelölt két jogszabályban a napidijak mértékét eltérően állapították meg, így Máramaros vármegye ennek kiküszöbölését olyan módon oldotta meg, hogy az egyes tisztviselők esetében azt a szabályzatot vette figyelembe, amelyben magasabb volt a napidij mértéke. ${ }^{750} \mathrm{~A}$ belügyminisztérium ennek kapcsán kifejtette, hogy az 1825. évi leiratra csak azon okból történt hivatkozás, hogy az abban foglalt rangfokozatokat és az ebből következő napidíjosztályzatokat vegyék alapul, a napidíjak mértékét már az 1862. évi szabályzat értelmében kell meghatározni. A minisztérium indokolta is a két napidíjszabályzat közötti jelentős eltérést: „’s koránt sem oly czélból [történt hivatkozás az 1825. évi leiratra], hogy az 1825ik évi igen csekély tiszti fizetésekre való tekintettel megállapitott magasabb napdijaknak élvezete a jelenlegi többszörösen nagyobb fizetésben részesülö megyei tisztviselökre kiterjesztessék, s miután a megyei tisztviselök napdijai, a volt m. $k$. helytartótanácsnak 1862ik évi april 3-án 16823 sz. a. kelt intézményével az emlitett dijosztályzat alapján a mostani viszonyoknak, 's az 1848ik év elötti tiszti fizetések tetemes emelkedésének megfelelóleg szabályoztattak, ezen szabályzatot a törvényhozás további intézkedéséig fentartatni kivánván." 751 A miniszteri tanácsosok ennek megfelelően Máramaros vármegye felterjesztését elutasították és felhívták a törvényhatóságot a megfelelő díjszabályzat alkalmazására.

A vármegyei önállóság széleskörű megnyilvánulása tapasztalható abban, hogy Máramaros vármegye erre válaszul 1869. június 1-jén kijelentette, hogy az új napidíjszabályzat elkészültéig a belügyminisztérium rendelete ellenére a központi kormányzat által jogszabályellenesnek minősített határozatát fogja alkalmazni. Erre válaszul 1870. január 3-án

745 MNL BM K150 117. 20991/1871.

746 MNL BM K150 117. 17808/1871.

${ }_{747}$ MNL BM K150 118.32051/1871.

748 MNL BM K150 118.31337/1871.

749 MNL BM K150 111.6311/1869.

750 MNL BM K150 111.6311/1869.

751 MNL BM K150 111.6311/1869. 
a belügyminisztérium a napidíjak egész országban való egységességének fontosságára figyelmeztette ismételten a megye közönségét, és a korábbinál jóval határozottabban elrendelte a megfelelő szabályzat alkalmazását. ${ }^{752}$

Máramaros vármegye azonban továbbra is kitartott álláspontja mellett, így 1870. május 2-án újabb feliratban megküldte a belügyminisztériumnak azon kívánságát, hogy a napidíjak kapcsán általuk helyesnek tartott értelmezést fogadja el a központi kormányzat. Ezt azzal indokolta, hogy a pénzügyminisztériumi tisztviselők napidíjai jóval magasabbak a vármegyei tisztviselőkénél, így ehhez kellene igazítani ezeket is, mivel a minisztérium által megszabott mérték nem fedezi a szállás- és az élelmezési költségeket. A kért szabályzat alkalmazása pedig azzal fenyegetett volna véleményük szerint, hogy „a hivatalos kiküldetésekbeni eljárás vagy épen nem, vagy felette késön fogna teljesittetni." ${ }^{\prime 53}$

Erre a felterjesztésre a belügyminisztérium csak 1871 februárjában reagált, mivel az iratra tett feljegyzés alapján az irattárban elveszett a beérkezett irat. A belügyminisztérium ismételten igyekezett kikényszeríteni az általa helyesnek vélt álláspont érvényesítését. ${ }^{754} \mathrm{~A}$ törvényhatóság azonban továbbra sem engedett a belügyminisztérium akaratának és indoklásul a megye viszonyait felhozva továbbra is kitartott eredeti felterjesztése mellett. ${ }^{755} \mathrm{~A}$ vármegye emellett felhívta a tanácsosok figyelmét arra, hogy a szolgabírák, mivel a közigazgatás és igazságszolgáltatás szervezeti elválasztása még elmaradt, jóval magasabb napidíjak mellett végezhetik a bírói megkereséseket, mint a közigazgatási eljárásokat, amely megoldás fenntarthatatlan. A belügyminisztérium végül a vármegyei határozat azonnali hatályon kívül helyezését rendelte el és felhívta Máramaros vármegye fóispánját, hogy az újabb nehézségek felmerülésének megakadályozása érdekében lépjen fel. ${ }^{756} \mathrm{Az}$ esetből kitűnik, hogy egy ellenálló törvényhatóság akaratának letörése jócskán „fejtörést” okozott a központi kormányzat számára. A vármegyék pedig az évszázados önkormányzati függetlenségüket nehezen adták fel az alkotmányos, parlamentáris kormányzat megjelenése ellenére is.

A napidíjak kapcsán kialakuló vitás ügy ismertetését követően érdemes megvizsgálni, hogy a fennforgó vita miképpen befolyásolta a járási tisztviselők napidíjait. A föszolgabírákat az akkori IX. osztályzatba sorolták, így kiszállásaikért az 1825. évi szabályzat értelmében $4 \mathrm{Ft} 20$ kr járt nekik, míg az 1862. évi rendelet szerint 3 Ft. Az alszolgabírák esetében ez a X. osztályzatnak megfelelően az 1825. évi díjszabásban 3 Ft 36 kr volt, míg az 1862. éviben $2 \mathrm{Ft} 50 \mathrm{kr}$. Az esküdtek a XII. osztályzatban voltak megtalálhatóak, és az 1825. évi szabályzat értelmében $1 \mathrm{Ft} 68$ kr volt a díjszabásuk, míg az 1862. évi szabályzat az ő esetükben kedvezőbb volt, mivel abban napidijuk 2 Ft-ra emelkedett. ${ }^{757}$

\footnotetext{
752 „[A] megye értelmes közönségének esmert hazafiui érzületénél fogva bizton elvárom, hogy jelen felhivásomnak eleget teend." - MNL BM K150 111.24922/1869.

753 MNL BM K150 111.8902/1870.

754 MNL BM K150 111. 8902/1870.

755 "[T]ekintve az itteni viszonyokat azok alig hasonlithatók más megyék viszonyaihoz, hol majd minden községben lakó urbirtokosok vagy uradalmak tiszjei szivesen látják el a tisztviselöket, míg megyénk alig nehány községeiben lakván urbirtokosok a tisztviselö rongyos és piszkos zsidó korcsmákra van szoritva, hol drága pénzen sem képes magát kellöen ellátni" - MNL BM K150 111.6992/1871.

756 MNL BM K150 111.6992/1871.

757 MNL BM K150 111.6311/1869.
} 
A fent ismertetett ügy megfelelö támpontot nyújt a vármegyék által az 1870:XLII. tc. alapján megállapított napidíjak vizsgálatához. A napidíjak kapcsán egységesnek mondható a tervezetekből formálódó azon szabályozás, hogy a szolgabírák csak a járásukon kívül vagy magánszemélyek ügyeiben való eljárás esetén tarthattak igényt napidíjra. ${ }^{758}$ Emellett a helyettesítést végző járást vezető tisztségviselő kapott napidíjat és előfogati díjat munkájáért ${ }^{759}$ viszont Doboka vármegye csak előfogati díjat nyújtott ilyen esetben számukra. ${ }^{700}$ Közügyekben a járás területén belül a megyei házipénztárból nem voltak jogosultak sem napidíjra, sem előfogati díjra. ${ }^{761}$ Ennek az az oka, hogy a szolgabírónak a járása beutazása hivatali kötelessége volt, így emiatt nem tarthatott igényt napidijra. ${ }^{762}$ Csongrád vármegye ugyanezen okból fektette le azt a szabályt, hogy a tisztviselők a közgyűlésen való kötelező jellegü részvételükért szintén nem számíthatnak fel napidíjat. ${ }^{763}$ Ez különösen azokra a szolgabírákra vonatkozott, akik a fizetésük mellett útiátalányra is jogosultak voltak, ${ }^{764}$ bár több törvényhatóság ezt úgy oldotta meg, hogy külön útiátalány folyósítása nélkül úgy tekintette: a tisztviselők fizetése ezt magában foglalja. ${ }^{765}$ A magánszemélyek ügyeiben a napidij megfizetése a feleket terhelte. ${ }^{766}$ Zala vármegye pedig az újoncozási költségeket kiemelte a többi költség közül, és ennek megfizetését a honvédelmi minisztériumhoz utalta. ${ }^{767}$ Fejér vármegye közönsége az általuk megállapított napidijakhoz indoklást is füzött: „A napidij meghatározásánál az illető állás fontossága és

758 „Általános szabályként kimondandó lenne, hogy a tisztviselőket és bizottm. tagokat a fentebbiek szerint szabályozott napidijak csak magán érdekü, vagy a megye területén, illetóleg a járási tisztviselökre nézve egyszersmind járásukon kivüli küldetésekben illetnék meg, ezen tisztviselök pedig a kik úti átalány élvezetében nem részesülnek elöfogati dijak fölszámitására is jogositva legyenek." - MNL BM K150 117. 21161/1871. - Békés vármegye; 21799/1871. - Bars vármegye; 21272/1871. - Doboka vármegye; 22026/1871. - Felső-Fehér vármegye; 118. 22592/1871. - Bereg vármegye; 22326/1871. - Komárom vármegye.

759 MNL BM K150 118. 22592/1871.

760 MNL BM K150 117.21272/1871.

761 MNL BM K150 117. 20171/1871. - Aranyosszék; 21161/1871. - Békés vármegye; 21272/1871. - Doboka vármegye; 17808/1871.; 27079/1871. - Fejér vármegye; 22026/1871.; 34430/1871. Felső-Fehér vármegye; 21800/1871. - Fogaras vidék; 21797/1871. - Szepes vármegye; 31267/1871. - Zala vármegye; 118. 22592/1871. - Bereg vármegye; 28726/1871. - Hont vármegye; 32051/1871. - Gömör és Kis-Hont vármegye; 22326/1871. - Komárom vármegye; 25309/1871. - Küküllő vármegye; 22691/1871. - Nógrád vármegye; 22336/1871. - Veszprém vármegye. MNL BM K150 117.21068/1871. - Csongrád vármegye.

763 MNL BM K150 117.21068/1871.

764 MNL BM K150 117.21161/1871. - Békés vármegye; 27079/1871. - Fejér vármegye; 118. 22592/1871. - Bereg vármegye; 22336/1871. - Veszprém vármegye.

765 „a végrehajtási tisztviselók, úgy mint (...) szolgabiró (...), kiknek fizetésében az útiátalány is ben foglaltatik köz és magán ügyekben a szék illetöleg a járás területén belöl a házi pénztár terhére napidijakat és elöfogati költségeket fel nem számithatnak." - MNL BM K150 117.20171/1871. - Aranyosszék ; 17731Sz/1871. Arad vármegye; 21272/1871. - Doboka vármegye; 22026/1871. - Felső-Fehér vármegye; 21800/1871. - Fogaras vidék; 20826/1871. - Sáros vármegye; 118. 28726/1871.; 31986/1871. - Hont vármegye; 25309/1871. - Küküllő vármegye.

766 MNL BM K150 117. 17731/1871. - Arad vármegye; 21272/1871. - Doboka vármegye; 22026/1871. - Felső-Fehér vármegye; 118. 22499/1871. - Kővár vidék.

767 MNL BM K150 117.31267/1871. 
rangja vétetett zsinormértékül - a nélkül azonban - hogy napidij osztályzat állitatott volna fel. ${ }^{768}$ Krassó vármegye a belügyminisztérium azon kérése nyomán, hogy csökkentsék a napidíjakat, szintén magyarázatot füzött a napidíjak mértékéhez, amely szerint az állam által az úrbéri perekben fizetett napidíjakat vették alapul. ${ }^{769}$

A napidij mértéke a köztörvényhatósági törvény végrehajtását megelőzően az országban egységesen $3 \mathrm{Ft}$ volt, amelyet Máramaros vármegye alacsonynak talált, így ezt kívánta megemelni. ${ }^{70} \mathrm{~A}$ többi vármegye ezt hasonlóan nem tartotta megfelelőnek, mivel néhány kevésbé tehetős törvényhatóság kivételével legalább ugyanilyen mértékü napidijat állapítottak meg. ${ }^{771}$ Ezek az erdélyi vármegyék közül kerültek ki, amelyekben a szolgabírák fizetése is jóval alacsonyabb volt, mint az ország többi részében. Kövár vidék a Máramaros vármegye ügyében már ismertetett 1825. évi szeptember 21-én 28696. sz. alatt kelt rendeletre hivatkozva állapította meg a szolgabírái napidíját 2 Ft 50 kr-ban még 1871-ben is. ${ }^{772} \mathrm{~A}$ Máramaros vármegye által felterjesztett táblázat alapján azonban úgy tünik, hogy ezt tévesen tették, mivel az 1862. évi szabályzatban foglaltak szerint inkább az alszolgabírói napidijaknak megfelelően szabhatták ezt meg. Sáros és Komárom vármegye szintén a Máramaros vármegye által citált 1825. évi és 1862. évi szabályzatra hivatkozva állapította meg a napidíjait, mivel kiemelték, hogy a belügyminisztérium ezt az 19026/1868. sz. rendeletével (kelt 1868. okt. 6-án) hatályban tartotta. ${ }^{773}$

Zala, Csanád, Szepes, Alsó-Fehér, Nógrád, Komárom és Zaránd vármegye $3 \mathrm{Ft}$ napidijat határozott meg a járást vezető tisztviselőinek. ${ }^{774}$ Fejér, Hont és Veszprém vármegye esetében a $4 \mathrm{Ft}$-nyi napidijat a belügyminisztérium befolyásának hatására csökkentették 3 Ft-ra. ${ }^{75}$ Emellett még Gömör és Kis-Hont vármegye módosította második tervezetében 6 Ft-ról 4-re. ${ }^{776}$ A 3 Ft-os napidíjnál Sáros ( $3 \mathrm{Ft} 50$ kr), Arad, Csongrád, Békés, Krassó, Trencsén $(4 \mathrm{Ft})$, Bars és Bereg vármegye $(5 \mathrm{Ft})$ határozott meg magasabb összegeket. ${ }^{777}$

A szolgabírák hivatalos utazásaik alkalmával fuvarköltségre vagy más néven előfogati díjra is jogosultak voltak. A tervezetek megalkotásakor ezek meghatározása az egyik legproblémásabb elem volt. A belügyminisztérium iránymutatása szerint a tisztviselök csupán a hivatalukkal együttjáró utazásaikat voltak kötelesek maguk fedezni, vagy a vármegye házi pénztárából kellett téríteni ezeket a költségeket. A magánfelek ügyeiben

768 MNL BM K150 117.27079/1871.

769 MNL BM K150 117.32636/1871.

770 MNL BM K150 111.6311/1869.

771 MNL BM K150 117. 20171/1871. - Aranyosszék (2 Ft); 21800/1871. - Fogaras vidék (2 Ft); 22026/1871. - Felső-Fehér vármegye (1 Ft 50 kr); 21272/1871. - Doboka vármegye (1 Ft 50 kr); 118. 25309/1871. - Küküllö vármegye.

772 MNL BM K150 118. 22499/1871.

773 MNL BM K150 117.20826/1871.; 118. 22326/1871.

774 MNL BM K150 117. 31267/1871.; 17803/1871.; 21797/1871.; 118. 31726/1871.; 22691/1871.; 22326/1871.; 25636/1871.

775 MNL BM K150 117. 17808/1871; 27079/1871.; 118. 28726/1871.; 31986/1871.; 22336/1871.; $30172 / 1871$.

776 MNL BM K150 118. 23816/1871.; 32051/1871.

777 MNL BM K150 117. 20826/1871.; 32702/1871.; 21068/1871.; 21161/1871.; 22226/1871.; 20991/1871.; 21799/1871.; 118.27001/1871. 
való eljárásuk alkalmával mind a napidíjuk, mind az előfogati díj megfizetése a magánfelek kötelezettsége volt. ${ }^{778}$

A törvényhatóságok szervezési munkálatai előtt, 1871. január 3-án Csanád vármegye a belügyminisztériumhoz fordult az előfogati dijak rendezése érdekében. A vármegye ugyanis az aktuális $1 \mathrm{Ft} 4 \mathrm{kr}$ helyett a régi 52 kr-ra szállította le a mértföldenkénti előfogati dijat, amelyhez az új törvény rendelkezéseinek megfelelően a belügyminisztérium jóváhagyását kérte. A vármegye közönsége ezt azzal magyarázta, hogy a magas fuvardijak miatt a megyei tisztviselők számára a járások beutazása nehézségekkel jár. ${ }^{779}$

A belügyminisztérium ennek kapcsán előbb a számvevőség állásfoglalását kérte, amely szerint az előfogati díjat $1 \mathrm{Ft} 4 \mathrm{kr}$-ra emelö 1868. szeptember 29-én 19026. sz. alatt kelt belügyminisztériumi körrendeletet éppen több vármegye kérésének engedve adták ki, ugyanis a korábbi 52 kr-os egységár az előfogatot kiszolgáltatót károsította. A számvevőség emellett kifejtette, hogy nem lenne kívánatos, ha a vármegyék számára lehetőséget teremtenének a napidijak és a fuvardijak szabadon való meghatározására, mivel ez a vármegyék közigazgatási szervezetének állami finanszírozását megnehezítené. A vármegye kérését így a belügyminisztérium „a köztörvényhatóságok küszöbön álló szervezéséig” visszautasította, mivel méltánytalannak vélte, hogy a tulajdonos lovait, kocsisát és kocsiját mindössze 52 kr-os mértföldenkénti áron a közigazgatási tisztviselő számára használatra átengedje. ${ }^{780}$

A belügyminisztériumi tanácsos által kilátásba helyezett szervezési munkálatok valóban újraszabályozták az előfogati díjakat. Több vármegye a korábbi szabályozáshoz igazodva 1 Ft 4 kr-ban határozta meg az előfogati díjat, ${ }^{781}$ vagy éppen a belügyminisztérium állapította meg ilyen módon a számukra felterjesztés hiányában. ${ }^{782}$ Zala vármegye pedig a már ismertetett ügyben is hivatkozott 1868. évi rendeletre hivatkozva szabta meg 1 Ft-ban az előfogati díjat. ${ }^{783}$ Ugyanilyen módon járt el Doboka és Zaránd vármegye is. ${ }^{784}$ Csanád és Arad vármegye esetében a belügyminisztérium módosította a fuvarköltséget 1 Ft 4 kr-ra, mivel a törvényhatóságok túl alacsony előfogati díjat szabtak meg. ${ }^{785}$ Csanád vármegye ugyanis úgy vélte, hogy a szolgabíráknak juttatott túl magas előfogati díj az alacsony utazási átalány miatt ellehetetlenítené a járási községek gyakori meglátogatását.

778 MNL BM K150 110. 1067/1871.

779 MNL BM K150 110. 1067/1871.

780 MNL BM K150 110. 1067/1871.

781 „Az elöfogati dij tárgyában eddig fennállott szabályrendelet - mely szerént mérföldenként 1 Ft 4 kr volt jogosan felszámitható - jövendöre is sinórmértékül szolgáland." - MNL BM K150 117. 27079/1871. - Fejér vármegye; 31913/1871. - Békés vármegye; 32636/1871. - Krassó vármegye; 27062/1871. - Sáros vármegye; 28525/1871. - Trencsén vármegye; 118. 28726/1871. - Hont vármegye (csak a megye határon belül); 22326/1871. - Komárom vármegye; 22499/1871. - Kővár vidék; 22336/1871.

- Veszprém vármegye.

782 MNL BM K150 118. 28989/1871. - Nógrád vármegye.

783 MNL BM K150 117.31267/1871.

784 MNL BM K150 117.21272/1871.; 118.25636/1871.

785 "[E]zen összeg jelenlegi gazdászati viszonyok közt annyira emelkedett fuvardijakkal arányban nem áll, s mert a fogattulajdonos szembetünö károsodása nélkül nem lehet követelni, hogy a fogat mértföldenként 52 kr-nyi dijért engedtessék át, mértföldenként 1 Ft 4 kr-ban állapitom meg." - MNL BM K150 117. 32702/1871. - Arad vármegye; 32776/1871. - Csanád vármegye. 
A törvényhatóság emellett a négylovas és a kétlovas kocsik fuvardiját eltérően kívánta megszabni, mivel négylovas fogatra csak a téli rossz minőségü utak esetén volt szükség, de ehhez a belügyminisztériumi tanácsos szintén nem járult hozzá. ${ }^{786} \mathrm{~A}$ belügyminisztérium ilyen módon való beleavatkozása az önkormányzati hatáskörbe azért érdekes, mivel Gömör és Kis-Hont vármegyében jóváhagyták a mindössze $50 \mathrm{kr}$-os fuvardíjat. ${ }^{787}$ Ehhez hasonlóan Krassó vármegye is külön szabályozta volna a két- és négylovas fogatokért fizetendő előfogati díjat, amelyet ebben az esetben sem engedélyezett a belügyminisztérium, hanem egységesen $1 \mathrm{Ft} 4 \mathrm{kr}$-ban állapította meg ennek összegét. ${ }^{788}$ Sáros vármegye esetében pedig az eltérő fuvardíjakat egységesítette a belügyminisztérium szintén $1 \mathrm{Ft} 4 \mathrm{kr}$-ban. ${ }^{789}$

A belügyminisztérium tehát az $1 \mathrm{Ft} 4 \mathrm{kr}$-os mértföldenkénti díjszabást vette alapul a korábbi rendeletének megfelelően. A vármegyék jelentős része azonban nem ehhez igazodott, hanem $1 \mathrm{Ft} 50 \mathrm{kr}$ mértföldenkénti fuvardijat állapított meg. ${ }^{790}$ Békés és Zaránd vármegye esetében már tapasztalható a technikai fejlödés megjelenése a közigazgatás területén is, mivel a szabályzataik a vasút segítségével megtett utazások esetében eltérést engedtek a meghatározott fuvarköltségtől, sőt Zaránd vármegye még a gőzhajóval való utazást is felvette tervezetébe ${ }^{791}$

\subsection{A szolgabírák felelősségi kérdései}

Az 1870:XLII. tc. egyik legfontosabb nóvuma a közigazgatási tisztviselők felelősségre vonhatóságának biztosítása, amelyet Récsi Emil a modern közigazgatás egyik legfontosabb követelményének tekintett. ${ }^{792}$ Ezt a jogintézményt alapjaiban alakította át az országgyủlés, ugyanis korábban a vármegyei közgyủlés kizárólagos jogosultsága volt a tisztviselők jogsértéseinek, munkájának ellenőrzése. Ezzel szemben az 1870:XLII. tc. úgy szervezte át ezt a rendszert, hogy a rendes bírósági szervezet hatáskörébe utalta a tisztviselők fegyelmi felelősségre vonását, ${ }^{793}$ ha a vizsgálat alapján azt a törvényhatósági bizottság a titkos szavazás során szükségesnek vélte. ${ }^{794}$ A köztörvényhatósági törvény szabályozta elsőként Magyarországon törvényi szinten a tisztviselők fegyelmi felelősségét. ${ }^{79} \mathrm{~A}$ törvényhatósági tisztviselők fegyelmi felelőssége mellett a köztörvényhatósági

\footnotetext{
786 MNL BM K150 117.27291/1871.; 32776/1871.

787 MNL BM K150 118.32051/1871.

788 MNL BM K150 117.32636/1871. - Krassó vármegye.

789 MNL BM K150 117.27062/1871. - Sáros vármegye.

790 MNL BM K150 117.20171/1871. - Aranyosszék; 34430/1871. - Felső-Fehér vármegye; 29328/1871. - Fogaras vidék; 21797/1871. - Szepes vármegye; MNL BM K150 118. 31726/1871. - Alsó-Fehér vármegye; 27001/1871. - Bereg vármegye.

791 „[A]z egyes tisztviselők által vaspályán tett utakról szóló fölszámitások a vasúti árjegyzékek szerént teendők.” - MNL BM K150 117.31913/1871. - Békés vármegye; 118. 25636/1871.

792 RÉCSI 1854, 22-23.

793 Sallai 2020a, 58-59.

794 SARLós 1976, 96.

795 Csizmadia 1976, 120.; SAllai 2020c, 253.
} 
törvény az anyagi felelősségre vonás szabályait is meghatározta az esetükben, ${ }^{796}$ amelynek elbírálására szintén a rendes bíróságok kaptak jogosultságot. ${ }^{797}$

Azt a jelentős változást, hogy a törvényhatóságok hatásköréből a rendes bíróságokhoz került át a tisztviselők felelősségre vonása, szemlélteti az altorjai báró Apor János volt háromszéki dulló (az erdélyi székely székek esetében a szolgabírói tisztség megfelelője) anyagi felelősségének megállapítása miatt indult eljárás. A dulló ellen Bárdocz Lajos emelt panaszt, mivel Apor a törvényszék által visszaküldött váltókeresetek közül a kézbesítés alkalmával az egyik eredeti váltóját elveszítette. ${ }^{798}$ A törvényszéki és a közigazgatási vizsgálatok egyértelműen igazolták, hogy a dulló vétkes a váltók eltűnésében, így a törvényhatóság 1867. június 13-ai határozatával minden kárért és költségért felelőssé tette. Apor azonban ennek ellenére nem térítette meg határidőre a panaszló kárát, hanem azt kérelmezte, hogy Bárdocz előbb a váltóban megjelölt adóson kísérelje meg behajtani a követelését, és csak ennek sikertelensége esetén léphessen fel vele szemben. Ennek a kérésnek végül helyt adott az erre feljogosított háromszéki tisztviselő.

A panaszló emiatt a belügyminisztériumhoz fordult. Az ügyet elbíráló tanácsos kikérte az igazságügyminisztérium véleményét, ${ }^{799}$ amelyet elfogadva igazat adott Bárdocznak, miszerint a sérelmes felet a volt dulló köteles kártalanítani, majd ezt követően érvényesítheti igényét az eredeti adósokkal szemben. ${ }^{800} \mathrm{~A}$ háromszéki tisztviselő azonban a váltókereset jogosultja által követelt pénzösszeget túlzónak találta, így mérsékelte azt. Bárdócz emiatt ismételten panasszal fordult a belügyminisztériumhoz. ${ }^{801}$

A belügyminisztériumi tanácsos ismételten az igazságügyminisztériumhoz fordult állásfoglalásért. Az igazságügyminisztériumi tanácsos maga is kiemelte, hogy ugyan ez korábbi javaslatával részben ellenkezik, de véleménye szerint a kártérítés feletti határozathozatal és az összeg behajtása nem a közigazgatási hatóságok hatáskörébe tartoznak, hanem azokat rendes bírói úton kell rendezni. Az igazságügyminisztériumi tanácsos azzal indokolta álláspontját, hogy az 1870:XLII. tc. alapján a kártérítési kereseteket az illetékes bíróságoknak kell elbírálnia. ${ }^{802} \mathrm{~A}$ belügyminisztériumi tanácsos Háromszéknek megküldött határozatában megismételte az igazságügyminisztérium álláspontját, és az ügy így a rendes bírósághoz került át. ${ }^{803} \mathrm{~A}$ fent ismertetett eset még 1866-ban keletkezett, tehát elbírálása alatt lépett hatályba a köztörvényhatósági törvény, így az anyagi felelösséget

\footnotetext{
796 SAllai 2020d, 134-35.

797 SARLÓs 1976, 94-95.

798 MNL BM K150 152. 1872.II.2. 25042/1869.

799 MNL BM K150 152. 1872.II.2. 25042/1869.

800 MNL BM K150 152. 1872.II.2. 1918/1870.

801 MNL BM K150 152. 1872.II.2.7714/1871.

802 „[A] szóban forgó kártérités körül eddigelé - közigazgatási uton - hozott határozatokat, a jelen viszonyok között, fökép azért sem tartom végrehajthatóknak, mert báró Apor János háromszéki volt duló ebbeli hivataláról idöközben lemondván, ezzel a politikai felsöbb hatóságot felette megilletett felügyeleti és fegyelmi hatóság megszünt, s mert az időközben életbe lépett 1870:XLII. t.cz. 73. I-a még a tettleg szolgálatban álló közigazgatási tisztviselök ellen intézett kárkereseteket is az illetékes biróság hatásköréhez utasitván, annál kevésbé lehet a szolgálatukból már kilépett, ily minöségü tisztviselök ellen kár megtéritése végett, közigazgatási uton végrehajtást eszközölni." - MNL BM K150 152. 1872.II.2. 4513/1872.

803

MNL BM K150 152. 1872.II.2. 39418/1872.
} 
elbíráló hatóságok közötti éles váltás figyelhető meg a két belügyminisztériumi döntésben. Az igazságügyminisztérium ugyanis első véleményében még elfogadta a megyei tisztviselők hatáskörét a dulló felelősségének megállapítására, azonban a belügyminisztériumnak megküldött második átiratában már egyértelmüen arra az álláspontra helyezkedett, hogy az ügy elbírálása a rendes bíróságok feladata az anyagi felelősségi szabályok értelmében.

A fegyelmi felelősséggel kapcsolatban merült fel a minisztérium előtt a fegyelmi vizsgálat alá vont tisztviselő helyettesítésének kérdése. A váczi alsó járás szolgabírája kapcsán adódott az a jogértelmezési probléma, hogy a föispán vagy a törvényhatósági bizottság jogosult-e a felfüggesztett tisztségviselö helyettesítéséről gondoskodni, amely megoldása végett a törvényhatóság a belügyminisztériumhoz fordult. Pest vármegye törvényhatósági bizottsága élve az 1870:XLII. tc. 43. \$ h) pontjában és 78. \$-ában meghatározott hatáskörével Mártonffy Györggyel szemben az ellene felmerült panaszok miatt fegyelmi vizsgálatot rendelt el és felfüggesztette hivatalából. A szükségessé vált helyettesítést a törvényhatósági bizottság kívánta gyakorolni, mivel véleménye szerint a közgyülés időtartama alatt szükségessé vált helyettesítés az önkormányzatiság elvének következtében és a $43 . \$ \mathrm{~g}$ ) pontja alapján a törvényhatósági bizottság feladata. Ezzel szemben a föispán az $53 . \$$ d) pontjára hivatkozva szintén magának tulajdonította ezt a jogosultságot. Az jelentette a problémát, hogy a $43 . \$ \mathrm{~g}$ ) pontjának „időközben föispánilag történt helyettesítések feletti intézkedés a jelen törvény 54 . és 55. \$-aiban meghatározott esetek kivételével” fordulatában miképpen kell értelmezni az „időközbent” és az „intézkedést”. A törvényhatósági bizottság az „időközbent” úgy értelmezte, hogy ez a két közgyűlés közötti időszakot jelöli. Ezzel szemben a megye föispánja a helyettesítést a közgyülés időtartama alatt is saját feladatának tartotta. ${ }^{804}$

A belügyminisztérium a főispán törvényértelmezését tartotta helyesnek, mivel a vármegye törvényhatósági bizottságának csupán az alispán helyettesítésére terjed ki a jogköre, míg a többi felfüggesztett tisztviselő helyettesítéséről a főispánnak kell gondoskodnia. A belügyminiszteri tanácsos kiemelte, hogy a többi tisztviselő esetében a törvényhatóságot a jogszabály csupán a helyettesítés feletti intézkedésre jogosítja, amelynek magyarázatát utólag törölték a belügyminisztérium rendelet tervezetéből. Ennek ellenére nem hagyható figyelmen kívül, ugyanis ez a szövegrészlet adhatja meg számunkra a helyes értelmezést. Nehezen magyarázható, hogy a tervezetet ellenőrző tanácsos miért vélte úgy, hogy szükségtelen ez az indoklás.

Az intézkedési jogkört tehát a belügyminisztérium a következőképpen magyarázta: „a törvény helyes értelmezése mellett csak is a főispán által helyettesített tisztviselőknek hivatalukba való elhelyezésére, az az a hivatalától felfüggesztett tisztviselőtől át vett hivatalos irományok és gondviselése alatt állott egyéb tárgyak átvétele és átadása 's a helyettesítettet megillető tiszti fizetvénynek utalványozása s. a t. s. a t. iránti intézkedésekre vonatkozhatik." ${ }^{805} \mathrm{~A}$ törvényhatósági bizottságnak tehát csupán a törvényszék által hivatalvesztésre ítélt szolgabíró esetében volt lehetősége az új tisztviselő megválasztására.

${ }_{804}$ MNL BM K150 153. 17532/1872.

805 MNL BM K150 153. 17532/1872 
Pest vármegye ugyanebben az ügyben később az országgyűlés kérvényi bizottságához fordult, amely a belügyminisztérium jogértelmezését helyesnek állapította meg. A korábbi indokláshoz hozzátéve: nincs jelentősége annak, hogy a helyettesítés a közgyűlés ideje alatt válik-e szükségessé. ${ }^{806}$

Zala vármegyében Nagy Farkas volt főszolgabíró fegyelmi ügye esetében annak kapcsán kellett a belügyminisztériumnak állást foglalni, hogy az eljárás alatti fizetésére a tisztviselö jogosult-e felmentése esetén. A vármegye ugyanis a felmentett tisztviselő két és fél év időtartamra járó fizetésének kiszolgáltatását megtagadta, amely miatt a volt föszolgabíró a belügyminisztérium irányába felfolyamodással élt. ${ }^{807}$

Nagy Farkas felfolyamodásában a bírák és bírósági hivatalnokok felelősségéről szóló 1871:VIII. tc.-re hivatkozott, amely értelmében a 65. § értelmében a felfüggesztése megszüntével a bíró jogosult a visszatartott javadalmazására ${ }^{808} \mathrm{~A}$ volt föszolgabíró felfolyamodásából érzékelhető, hogy csupán három év telt el az igazságszolgáltatás és közigazgatás elválasztását kimondó törvény megszületése óta. A két különálló szervezet kiépülése pedig csupán 1872-ben valósult meg.

A belügyminisztérium az ügy kapcsán előbb kikérte a kebelbeli számvevőség véleményét, amely szerint a felfüggesztéssel a föszolgabíró elveszítette vármegyei megbízatását, így megszűnt a jogosultsága a fizetésére, mivel másik személyt kellett alkalmazni feladatai ellátására. Emellett pedig kiemelték, hogy Nagy Farkas szolgáltatott okot az eljárás megindítására. A belügyminisztérium Veszprém vármegye alispánjától is állásfoglalást kért. Ebben a címzett kifejtette, hogy a hivatkozott jogszabály a „birósági állam és nem megyei hivatalnokok elleni eljárást szabályozó törvény", így ebben az ügyben nem alkalmazható. A belügyminisztérium végül a felfolyamodást - az alispáni indoklást magáévá téve - elutasította, azzal indokolva határozatát, hogy a hivatkozott törvény nem vonatkozik az érintettre. ${ }^{809} \mathrm{Az}$ eset ismeretében kimondható, hogy a felfüggesztett tisztviselő elveszítette jogosultságát fizetésére, amely azt jelentette, hogy ebben az esetben is a bírák jogállása kedvezőbb volt, mint a közigazgatási tisztviselöké.

A törvényi szabályozás ellenére a belügyminisztérium az enyhébb fokú szabálysértések esetén nem ellenezte, hogy a felelősségi eljárás során a felelősség megállapítása ellenére a tiszti kereset megindításától a rendes törvényszék előtt a vármegye közönsége eltekintsen. 1871-ben Veszprém vármegyében Csapó Ignácz tiszteletbeli esküdt egy mezei rendőrségi ügyben megsértette az illetékességi szabályokat és eljárása során „túlzásba esett”. A vármegye a vizsgálat során elismerte az esküdt törvénytelen eljárását, ám elegendőnek tartotta, ha az esküdt irányában csupán közgyülésileg kifejezi rosszallását. A belügyminisztérium egyetértett a vármegye döntésével, így helybenhagyták azt. ${ }^{810}$

\footnotetext{
MNL BM K150 153. 17532/1872

807 MNL BM K150 217. 42404/1872.

808 MNL BM K150 217. 42404/1872.

809 MNL BM K150 217. 42404/1872.

810 MNL BM K150 111. 14588/1871.
} 


\subsection{A törvényhatósági tisztviselők összeférhetetlensége az országgyülési képviselői megbízatással}

A rendi korban törvényeink az országgyűlés tagjaira vonatkozó összeférhetetlenséggel csak az éppen felmerülő problémák kapcsán érintőlegesen foglalkoztak, így a polgári korszakban a törvényhozóra várt az erre vonatkozó szabályozás megalkotása. ${ }^{811}$ Ehhez kapcsolódtak a törvényhatósági tisztviselök összeférhetetlenségi, úgynevezett inkompatibilitási szabályai.

Már 1848-ban az első népképviseleti országgyűlésen felmerült a kérdés rendezésének szükségessége, de ekkor nem is tárgyalták a benyújtott törvényjavaslatokat, az 1848:V. tc. pedig nem foglalkozott a kérdéssel. ${ }^{812} \mathrm{Az}$ alkotmányosság helyreállítását követően már az 1865-ben összehívott országgyűlésen ismételten felvetődött az inkompatibilitás szabályozásának szükségessége. ${ }^{813} \mathrm{Az}$ 1866-ban benyújtott törvényjavaslat csupán a kormány kinevezésétől függő hivatalnokok számára tiltotta meg az országgyủlési képviselői tisztség betöltését. Az ennek nyomán elfogadott képviselőházi határozat szintén ugyanezen személyi kör számára írta elő a parlamenti illem alapján, hogy kinevezésüket követően új választásnak vessék alá magukat. ${ }^{814}$

A képviselőházi határozat azonban nem volt kellően hatékony az országgyülési képviselők összeférhetetlenségének megoldására. ${ }^{815} \mathrm{Az}$ országgyülés Képviselőházában Bobory Károly ellenzéki képviselő 1868. november 10-én, majd december 5-én ismételten az 1866-ban benyújtott törvényjavaslat tárgyalásra való kitűzését kérte. ${ }^{816}$ Széll Kálmán a központi bizottság álláspontját a törvényjavaslat kapcsán végül 1868. december 6-án ismertette, amely alkalommal Nyáry Pál új törvényjavaslatot nyújtott be az országgyűlési képviselői összeférhetetlenség kapcsán. ${ }^{817}$ A központi bizottság az ülésszakból hátralévő rövid időre hivatkozva azt javasolta, hogy határozatban utasítsák a minisztériumot a következő országgyülésre egy törvényjavaslat kidolgozására. A Képviselőház végül elfogadta a központi bizottság álláspontját. ${ }^{818}$ A döntést megelőzően felszólalásában Deák Ferenc felhívta arra a figyelmet, hogy érdemes megfontolni az új törvényjavaslat megalkotásakor azt, hogy a megyei közigazgatási tisztviselői pozíció is összeférhetetlen legyen az országgyülési megbízatással, mivel ez évekre elvonja az adott egyént a feladata ellátásától és célszerütlen a helyettesítésük. ${ }^{819}$

A törvényhatóságok pártolták az inkompatibilitási törvényt. Bereg vármegye 1868 márciusában a Képviselőháznak címzett feliratában kezdeményezte, hogy a kormány-

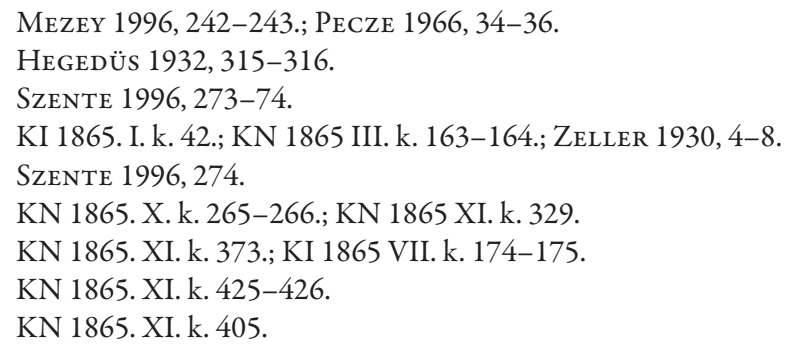


hivatalnokok országgyűlési képviselői tisztséget ne tölthessenek be, megválasztásuk esetén valamelyik pozíciójukról le kelljen mondaniuk. ${ }^{820} \mathrm{~A}$ felterjesztésnek a célja az államhatalmi ágak elválasztásának megvalósítása volt, valamint az, hogy az országgyűlési képviselők csupán a törvényhozási feladataikra irányíthassák figyelmüket. Bereg vármegye javaslatát kilenc törvényhatóság támogatta, amelyek közül Ugocsa vármegye azzal egészítette ki a kezdeményezést, hogy a megyei tisztviselőkre is ki kellene terjeszteni az összeférhetetlenségi szabályokat, tehát csak akkor lehetnének országgyűlési képviselők, ha hivatalukról lemondanak. ${ }^{821}$

Az 1869 áprilisában összehívott országgyủlés azonban továbbra sem alkotott jogszabályt az országgyülési képviselői összeférhetetlenség tárgyában, bár több alkalommal is igyekeztek az ellenzéki képviselők kikényszeríteni azt, hogy az elfogadott országgyülési határozatnak megfelelően mondjanak le az azzal összeütközésben állók. ${ }^{822}$ Emellett pedig az egyes törvényekben, partikulárisan szabályozta az országgyűlés a bírák vagy az állami számvevőszék tisztviselőinek inkompatibilitását az egységes szabályozás helyett. ${ }^{823}$

Az általános összeférhetetlenségi törvény megszületésének elmaradása miatt 1869. december 6-án Udvarhelyszék felirattal fordult a Képviselőházhoz, amelyben kifejtette, hogy aggályosnak tartják a törvényhatósági tisztviselők képviselőházi tagságát. Az országgyűlési képviselők ugyanis ezáltal két fizetést élvezhettek és a törvényhatóságok emiatt arra kényszerülnek, hogy fizetés nélküli helyettesítések által oldják meg a pótlásukat. A törvényhatóság erre hivatkozva kérte az inkompatibilitási törvény megalkotását a Képviselőháztól. ${ }^{824}$ Udvarhelyszék felterjesztéséhez mintegy 23 törvényhatóság csatlakozott. ${ }^{825}$ Pest, Pilis és Solt t. e. vármegyék közönsége Udvarhelyszék elöterjesztését azzal egészítette ki, a parlamentarizmus elvéből következik a végrehajtás törvényhozástól való elválasztása, ahogyan már megtörtént az igazságszolgáltatás és a végrehajtás elválasztása is. ${ }^{826} \mathrm{~A}$ támogató feliratok azonban már korántsem csak a törvényhatósági tisztviselők összeférhetetlenségére helyezték a hangsúlyt, ahogyan Udvarhelyszék felterjesztése, hanem elötérbe került a kormányhivatalnokok összeférhetetlensége is az országgyuullési képviselöi megbízatással. Győr és Doboka vármegye Képviselőházhoz intézett támogató felterjesztése fókuszált még a törvényhatósági tisztviselők inkompatibilitására Udvarhelyszékhez hasonlóan. ${ }^{827} \mathrm{~A}$ Képviselőház a beérkezett kérvényeket mindkét esetben továbbította a belügyminisztériumnak, ahol feljegyezték, hogy az inkompatibilitási törvény megalkotásakor szükséges ezeknek felhasználása. Azonban az iratokon található feljegyzések alapján egyéb intézkedés nem történt. ${ }^{828}$

\footnotetext{
820 MNL BM K150 111.76/1869.

821 MNL BM K150 111.76/1869.

822 Zeller 1930, 19-33.; SZENTE 1996, 275.

823 1869:IV. tc. 8.\$ a); 1870:XVIII. tc. 4.\$.

824 MNL BM K150 111. Sz263/1869.

825 MNL BM K150 111. 9339/1871.; 15854/1870.; 6933/1870.

826 MNL BM K150 111. 15854/1870.

827 MNL BM K150 111. 15854/1870.; 6933/1870.

828 MNL BM K150 111. 9339/1871.; 15854/1870.; 6933/1870.
} 
Az ellenzéki követelések okán végül Tóth Vilmos belügyminiszter 1872. március 6-án előterjesztette az országgyűlési képviselők összeférhetetlenségét szabályozó törvényjavaslatot. ${ }^{829} \mathrm{Ez}$ már tartalmazta a fentebbiekben ismertetett törekvéseknek és a belügyminiszter minisztertanácson elhangzott hozzászólásának megfelelően a törvényhatósági és községi tisztviselők összeférhetetlenségét is. ${ }^{830}$ Annak ellenére, hogy konkrét intézkedést nem jegyeztek fel a belügyminisztériumi iratokon, a törvényhatóságok kérvényei minden bizonnyal befolyásolták a belügyminisztert a törvényjavaslat elkészítése során. Érdemes azonban megjegyezni, hogy a minisztertanácsi jegyzőkönyv arról tanúskodik, hogy a törvényhatósági tisztviselők beemelése az inkompatibilitás körébe részben a törvény elodázását is célozta. A jogszabály tervezet alapján viszont úgy tünik, hogy a szabályozás készítői Deák Ferenc országgyülési felszólalásához és Udvarhelyszék feliratához hasonlóan úgy vélték, e tisztviselők esetében a legfőbb probléma, hogy nem tudják ellátni feladataikat. A fővárosi municipális tisztviselők esetében így kivételt engedett az összeférhetetlenség alól. A központi bizottság által módosított törvényjavaslatból azonban ez a kedvezmény már kikerült. ${ }^{831}$ Az ellenzéki obstrukciónak köszönhetően végül a törvényjavaslat tárgyalása nélkül feloszlatták az országgyülést. ${ }^{832}$

A kérdés 1873-ban került ismét napirendre, amikor a kormánynak a kérdésben mutatott határozatlanságát megelégelve a Deák-párti képviselők november 15-én egy kilenctagú bizottság kiküldését javasolták a törvényjavaslat kidolgozására, amelyet a Képviselőház az indoklást követően november 18-án egyhangúlag elfogadott. ${ }^{833} \mathrm{~A}$ kiküldött bizottság 1874. június 1-jén terjesztette elő jelentését. ${ }^{834} \mathrm{~A}$ törvényjavaslat egyértelműen kimondta a törvényhatósági és községi tisztviselői megbízatás összeférhetetlenségét az országgyűlési képviselőséggel. ${ }^{835}$ Ezt a bizottsági jelentés azzal indokolta, hogy e hivatalnokok az állami közigazgatásnak is végrehajtó közegei, valamint túlzott megterheléssel jár a két pozíció betöltése. Itt is kiemelték, hogy a törvényhatóságok az 1870:XLII. tc.-ben meghatározott eseteken kívül nem jogosultak a tisztviselők helyettesítésére. ${ }^{836} \mathrm{Az}$ indoklás tehát a hatalmi ágak elválasztásának követelményével is igazolta az esetükben az összeférhetetlenség kimondásának szükségességét, nem csak a törvényhatósági feladatok elhanyagolásának kívántak ezáltal gátat szabni.

A törvényjavaslat részletes tárgyalása során Mocsáry Lajos a 48-as párt képviselőjeként vitatta a törvényhatósági tisztviselők kizárásának jogosságát az országgyűlési képviselö-

KN 1869. XXII. k. 174.

KI 1869. XV. k. 117-118.; MNL W 12 1872.01.21.

KI 1869. XV.k. 287-288.

ZELLER 1930, 42.

KI 1872. IX. k. 20.; KN 1872. VIII. k. 24.; 41-43.

KN 1872.X.k. 340.

A kiküldött bizottság által elkészített törvényjavaslat és indoklása sajnálatos módon nem található a képviselőházi irományokat tartalmazó kötetben. Zeller Árpád az országgyủlési képviselők összeférhetetlenségéröl írott munkájában minden bizonnyal emiatt nem közölte azt. Az általa elemzett indokolásnál pedig nem jelölte meg a forrást, emiatt a munkában megjelent bizottsági jelentésre hivatkoztam. Az eredeti törvényjavaslatra a központi bizottság által átdolgozott tervezetből lehet következtetni. - KI 1872. XVII. k. 318-320.

836

ZELLER 1930, 52.
} 
ségből, mivel csak a törvényhatóságok választóitól függnek ezek a személyek, és nem a kormánytól ${ }^{837}$ Emiatt úgy vélte, hogy a szabályozásnak ez a része csupán a kormánypárt „bosszúja” a kormánytisztviselők összeférhetetlenségének megállapítása miatt, ugyanis ez fóként az ellenzék által pártolt választott tisztviselőket sújtaná. A felszólaló beszéde végén korábbi érveivel szembehelyezkedve azzal zárta beszédét, hogy felesleges szabályozni e személyi kör inkompatibilitását, mert a két tisztség egyidejűleg nem látható el, így az érintettek mindenképpen lemondanának ilyen esetben.

Pólya József kormánypárti képviselő reagált az elhangzottakra. ${ }^{838}$ Egyetértett azzal, hogy nem a kormánytól való függőségük miatt kell szabályozni a törvényhatósági tisztviselők összeférhetetlenségét, hanem azért, hogy „a munka-körök tulhalmozottságát” elkerüljék. A Mocsáry által kifejtettekkel ellentétben ugyanis nem minden esetben mondanak le az országgyưlési képviselők korábbi hivatalaikról, így alispánok és szolgabírák is találhatóak a képviselőházi padsorokban, akik így nyilvánvalóan nem képesek megfelelően ellátni feladataikat. A kedvelt tisztviselők esetében ugyanis gyakran a törvényhatóságok a lemondatás helyett inkább a helyettesítéssel igyekeznek megoldani a problémákat.

Tisza Kálmán is megjegyezte, hogy a tisztviselök függetlenek, mivel csupán a törvényhatóságnak tartoznak felelősséggel. Emellett kifejtette, hogy az országgyűlési képviselők jelenleg is csupán törvényellenesen tölthetnek be törvényhatósági tisztséget. ${ }^{839}$ Azért vélte törvényellenesnek ezt a megoldást, mert véleménye szerint az 1870:XLII. tc. alapján az időközben megüresedő tiszti állomás csupán a következő rendes közgyűlésig tölthető be helyettesítés útján, mivel azon már új választásra nyílik lehetőség. A debreceni képviselő valószínűleg a törvény 72 . §-ára hivatkozott felszólalásában, amely szerint a megürült állomásokat a következö rendes közgyűlésen kell betölteni, ameddig az elkerülhetetlenül szükséges esetekben a tisztviselő helyettesítéséről a föispán gondoskodhat. A törvényszöveg alapján abban merülnek fel kétségek, hogy a képviselői megbízatás elnyerésekor „megürültnek” tekinthetö-e egy állomás. Azonban, ha ebben az esetben nem is tekintjük „megürültnek” azt, akkor is törvényellenes volt a törvényhatóságok megoldása, mert csak felfüggesztett tisztviselők esetében nyílt lehetőség azok helyettesítésére. A felfüggesztésre pedig csak valamilyen fegyelmi vétség esetén kerülhetett sor, ${ }^{840}$ így országgyülési képviselöi feladatainak ellátása okán bekövetkező távollét esetén nem.

Az elhúzódó törvényalkotási folyamat során e törvényszakasz kapcsán több felszólalás nem hangzott el és azt az eredeti formájában elfogadta a Képviselőház, ${ }^{841}$ ennek megfelelöen, mivel a törvényjavaslat e részét a Förendi Tábla sem vitatta, ${ }^{842}$ az 1875 -ben becikkelyezésre került összeférhetetlenségi törvénycikk tartalmazta a törvényhatóságok kérvényeivel egyező módon a törvényhatósági tisztviselői tisztségek összeférhetetlenségét az országgyülési képviselői megbízatással. ${ }^{843}$

837 KN 1872. XI. k. 127-128.; ANTAL 2013b, 635.

838 KN 1872. XI. k. 128-129.; ANTAL 2013b, 625.

839 KN 1872. XI.k. 129-130.

${ }_{840}$ 1870:XLII. tc. $43 . \$$ h), 53. \$c), 55. §.

841 KN 1872. XI. k. 130.; Pecze 1966, 42.

842 FN 1872. II. k. 352-354.

843 1875:I. tc. 3. \$a) 
A Pólya József felszólalásában elhangzottak valódiságát támasztja alá az alábbi jogeset, amely egyben azt is igazolja, hogy miért volt szükség a törvényhatósági tisztviselők inkompatibilitásának szabályozására. Máramaros vármegye alispánja 1872-ben a törvényhatósági tisztviselők összeférhetetlenségével kapcsolatos ügyet terjesztett a belügyminisztérium elé. Máramarossziget választóközönsége 1872. július 4-én ugyanis a balközép párti Szaplonczay Miklós tiszavölgyi járási szolgabírót a máramarosszigeti választókerület országgyülési képviselöjévé választotta. ${ }^{844} \mathrm{Az}$ alispáni jelentés arról tudósított, hogy a törvényhatósági bizottság szeptember 12-ei közgyủlésén a szolgabíró tiszti állomását megüresedettnek nyilvánította és megválasztották az új tisztségviselöt. Emellett pedig a törvényhatósági bizottság szabályrendeletben kimondta, hogy az országgyűlési képviselővé választott törvényhatósági tisztviselő hivatalát nem tarthatja meg. Ezáltal a vármegye figyelmen kívül hagyta Szaplonczay Miklós azon kérvényét, amelyben csupán helyettesítését kérte a képviselői megbízatás időtartamára. ${ }^{845}$

Az alispáni jelentés kifejtette, hogy a bírák jogállását szabályozó 1869: IV. tc. kimondta a bírák összeférhetetlenségét az országgyülési képviselőséggel, viszont az 1870:XLII. tc. ilyen rendelkezést nem tartalmazott a törvényhatósági tisztviselőkre nézve. Ellenben véleménye szerint a közigazgatás érdeke megkívánja, hogy a szolgabírói állomást huzamosabb ideig ne hagyhassa el a megválasztott tisztviselő, így a törvényhatósági bizottság jogosult a mandátumot megszüntetni és új szolgabírát választani. ${ }^{846} \mathrm{~A}$ törvényhatósági bizottság határozatával szemben nem Szaplonczay Miklós élt felfolyamodvánnyal, hanem a törvényhatósági bizottság tagjai közül Markos István és érdektársai fordultak a belügyminiszterhez.

A belügyminisztérium a felfolyamodást alaptalannak tartotta és így a törvényhatósági bizottság határozatát nem semmisítette meg. ${ }^{847}$ A döntést viszont elég szűkszavúan indokolta. Az eset kapcsán pedig voltak megoldásra váró kérdések, amelyekre nem tért ki a belügyminisztériumi tanácsos. A törvényhatóság az 1870:XLII. tc. 7. \$-a értelmében terjesztette fel a szabályrendeletet a belügyminisztériumnak, amely szerint a szabályrendeletek ellen az érdekeltek a szabályszerű kihirdetéstől számított 30 nap alatt az illető miniszterhez folyamodhattak. Az alispáni jelentés vitatta, hogy Markos István és társai az érdekeltek körébe sorolhatók-e, mert véleményük szerint a határozattal szemben csupán Szaplonczay Miklós élhetett volna a felfolyamodással. Erre a kérdésre egyáltalán nem tért ki indoklásában a miniszteri tanácsos.

A törvénycikk 5.\$-ából következett, hogy a belügyminisztérium a hozzá intézett felfolyamodás esetén a felirati jog gyakorlása által csupán a törvénnyel vagy kormányrendelettel ellenkező szabályrendeletet semmisíthetett meg. Ezt igazolta is a belügyminisztérium reakciója. Ebben azonban csupán arra tért ki a belügyminisztériumi tanácsos, hogy az

\footnotetext{
Antal 2013b, 640.

MNL BM K150 111.33617/1872.

${ }^{846}$ „Midőn tehát a megyei közgyülés Szaplonczay Miklósnak jelentésébooll arról értesült, hogy ő országgyülési képviselövé lett megválasztása alkalmából 3 évi idötartamra eltávozik, a kérelmezett helyettesitést a többször idézett 1870 évi XLII. t. czikk 25-ában körvonalazott önkormányzati jogánál fogva jogosan tagadhatta meg, miután ennyi idöre szabadságoltatásához engedélylyel járulni nem akart.” - MNL BM K150 111. $33617 / 1872$.

847 MNL BM K150 111.33617/1872.
} 
összeférhetetlenségi törvény hiányában nem kifogásolhatja a közgyülési határozatot, mivel az a közszolgálat érdekeivel összhangban van. Arra nem adott választ, hogy a közgyülési határozat összhangban van-e az 1870:XLII. tc. rendelkezéseivel. ${ }^{848}$

Az elemzett esetből az a következtetés adódik, hogy a jogalkotó jogosan vonta be az országgyűlési képviselőséggel való összeférhetetlenség körébe a törvényhatósági tisztviselőket, mivel az egyértelmű szabályozással a belügyminisztérium határozatában tapasztalható elvi bizonytalanságot sikerült megszüntetni. A Mocsáry által kifejtetteket szintén cáfolja Szaplonczay Miklós ügye, mivel az érintett nem kívánt lemondani tisztségéről, bár a törvényhatóság ezzel ellenkező állásfoglalását követően már nem törekedett a pozíciója megtartására. Emellett pedig a szabályozás megalkotására való valós igényt mutatják a törvényhatóságok feliratai is.

\subsection{A szolgabírói életpálya bemutatása}

A szolgabírák szolgálati jogállásának szabályozása kapcsán érzékelhető mind a törvényhozói részről, mind a törvényhatóságok oldaláról, hogy a történeti hagyományok tiszteletben tartásával igyekeztek minél népszerűbbé tenni a vármegyei tisztviselői életpályát. E törekvés jele volt, hogy a jogalkotó immár hat évre nyújtotta a szolgabírák mandátumát, viszont a rendi tradíciók iránti nosztalgia meggátolta, hogy az igazán megoldást jelentő élethosszig tartó kinevezési rendszer megvalósulhasson a törvényhatósági tisztviselők esetében. Ennek következménye volt, hogy a szolgabírói tisztség nem biztosított egész életen át tartó megélhetést, ${ }^{849}$ így betöltői nyugdíjra sem számíthattak biztosan. ${ }^{850}$ Nyugdíjra nemcsak a választott tisztviselők, hanem az államkincstár terhére a segéd- és kezelőszemélyzet sem tarthatott igényt. Ezt igazolja Pápay Sándor volt csendbiztos és Varga Mihály volt megyei hajdú esete is, amelyek esetében a belügyminiszérium elutasította az erre irányuló kérelmeket. ${ }^{851}$ Érdemes ennek kapcsán megjegyezni, hogy a bírák számára már a jogalkotó kilátásba helyezte a nyugdijjogosultság lehetőségét a szervezeti átalakítások alkalmazásával, de ennek pontos kidolgozása 1885-ig váratott magára. ${ }^{852}$

\footnotetext{
${ }^{848}$ „Az országos képviselöi megbizatás, s a törvényhatósági tisztviselői állomás összeférhetetlensége iránt törvény nem tétetvén ennél fogva, a neheztelt közgyülési határozat a hatáskörömmel járófelügyeleti jog alapján csak is azon szempontból képezheti birálatom tárgyát, vajjon a szóban levö szolgabirói állomásnak betöltésére vonatkozó s a megyei önkormányzat jogköréhez tartozó intézkedés a közszolgálat érdekeinek megfelel-e vagy sem?" - MNL BM K150 111.33617/1872.

849 „Nem hagyhatók figyelmen kivül a felelösség elvéböl kifolyó, 's néha a legjobb szándék - és szorgalom mellett is, elóállható következmények; nem föként azon körülmény hogy a közigazgatási tisztviseló hivatala nem örökös, nem jutalmazza a szorgalmat és hüséget egy egész életen át, ezt csak addig fizetik, míg a munkát birja; söt legyen bár a leghivebb - szorgalmasabb - és képesebb, minden választás alkalmával ellene fordulhat az urna." - MNL BM K150 117.21068/1871. - Csongrád vármegye.

850 MNL BM K150 117.20171/1871. - Aranyosszék; 32636/1871. - Krassó vármegye; 21797/1871. Szepes vármegye; 21949/1871. - Temes vármegye; 118. 22499/1871. - Kövár vidék.

851 MNL BM K150 112. 1871. II. 3.t. 18517/1870.; 1871. II. 2.t. 1592/1871.

852 ANTAL 2003, 723.
} 
A törvényhatóságok által meghatározott szolgabírói fizetések és az azokhoz füzött indoklások arra utalnak, hogy a vármegyék igyekeztek a szolgabírák számára nyújtott fizetések, plusz juttatások, napidíjak és előfogati díjak segítségével vonzóvá tenni a szakképzett fiatalok számára a közigazgatási szolgálatot. A legtöbb vármegye képes volt a szolgabírái számára tisztes megélhetést nyújtani, azonban valósnak tünik a törvényhatóságok azon aggálya, miszerint a legkiválóbbakat „elszívják” az ennél jóval jövedelmezőbb állások. A legnagyobb problémát valóban az jelenthette a közigazgatási és igazságszolgáltatási szervezet 1872-ben megvalósuló elválasztásakor, hogy az állam által dotált bírók magasabb fizetésre váltak jogosulttá, mint a törvényhatósági tisztviselők. Márpedig a megyei hivatalnokok jelentős része még 1871-ben is részt vállalt az igazságszolgáltatási teendők ellátásában.

A szolgabírák javadalmazásának összevetése a többi tisztségviselő fizetésével azt mutatja, hogy a legtöbb vármegyében a szolgabírák az elismert tisztségek közé tartoztak. Csupán az alispán, az árvaszéki elnök és a föjegyző helyezkedett el egyértelműen „felette a ranglétrán”. Különös, hogy a szakképzettséghez kötött tisztségek (mérnök, föorvos, állatorvos) betöltőit jellemzően kevésbé honorálták, mint a „tradicionális” tisztviselőket (szolgabírák, számvevő, tiszti ügyész, pénztárnok).

A szolgabírákra vonatkozó közszolgálati szabályok (fizetés, napidíj, előfogati dij) a törvényhatóságoknak biztosított széleskörü önkormányzatiság okán partikuláris képet mutattak a törvény megszületését követően. ${ }^{853} \mathrm{~A}$ szétaprózódott jogi szabályozás és a szolgálati pragmatika hiányának következtében a vármegyei tisztviselőkre vonatkozó egységes szabályozás nem jöhetett létre. Ezt jól szemlélteti két vármegye példája, amelyek esetében a szolgabírák hat hét időtartamú szabadságra voltak jogosultak, ${ }^{854}$ viszont a többi törvényhatóság tervezetéből hiányoznak az erre vonatkozó rendelkezések, így egyértelmüen nem állapítható meg, hogy mi volt az erre vonatkozó gyakorlat. Az 1869:IV. tc. szintén hat heti szabadságot engedélyezett a bírák számára, így látható, hogy ebben is igazodtak az igazságszolgáltatási személyzet munkafeltételeihez. ${ }^{855}$ A szolgabírák munkakörülményeire szintén csak szórványos utalások találhatók, csupán Hont vármegye szabályozta tervezetében a szolgabírói hivatal müködését. ${ }^{856}$ Ennek köszönhető az, hogy egybefüggő kép nem alkotható a szolgabírákra vonatkozó közszolgálati szabályokról.

$\mathrm{Az}$ ismertetett felelösséggel és összeférhetetlenséggel összefüggő jogesetek alapján arra a megállapításra juthatunk, hogy a belügyminisztériumi tanácsosok csupán az aktuálisan felmerülő esetek eldöntésére törekedtek, az elvi jelentőségű megállapításoktól való tartózkodásuk figyelhető meg. Ugyanez állapítható meg a fizetésekről, napidíjakról és előfogati díjakról rendelkező törvényhatósági tervezetek megerősítésénél is.

853

854 szabadságot adhat. Hosszabb idöre csak a megyei közgyülés adhat a körülmények tekintetbe vétele mellett
szabadságot." - MNL BM K150 117. 22026/1871. - Felsö-Fehér vármegye; 21272/1871. - Doboka vármegye.

855

856 


\section{A SZOLGABÍRÁK HATÁSKÖRE}

A jogalkotó az 1870:XLII. tc. 62.\$-ában általános jelleggel szabályozta a járás élén álló tisztviselők hatáskörét, miszerint felügyel a hatósága alatt álló községekre, és gyakorolja azon jogokat és teljesíti azon kötelességeket, amelyeket a törvény és a szabályrendeletek ráruháznak. ${ }^{857} \mathrm{~A}$ községek müködésében betöltött kiemelt szerepén túl, így a törvényhozó feladatköreiket részletesen nem határozta meg. Emiatt a vármegyéknek nyílt lehetőségük a szolgabírák hatáskörének alapos szabályozására. A közigazgatás polgári átszervezése ebben jelentős változásokat idézett elö, mivel az 1869:IV. tc. a közigazgatás és az igazságszolgáltatás elválasztásával leválasztotta a járást vezető tisztviselőkről a törvénykezési hatásköröket. ${ }^{858}$

A szolgabírák hatáskörét nem minden törvényhatóság szabályozta. Arad vármegye elegendőnek találta az 1870:XLII. tc. szolgabírákra vonatkozó rendelkezéseit. ${ }^{859}$ Csanád vármegye pedig ezt a következő indokkal mellőzte: „A tiszti kar munka köre meghatározásánál [...] csak a szük körvonalazásra szoritkoztunk, 's a tisztviselöt müködésében rideg \$ok tömkellegével zsibbasztani nem akartuk. A törvént és fennálló szabályrendeleteket mindenütt figyelembe véve alkottuk a határozott szövegü utasitást, részletekre csak ott bocsájtkozva a hol a rendeletek kül alakja és az ügymenet gyorsasága megkivánta, jól tudván, hogy mennél több a szabály annál több a kibuvó ajtó." 860 A vármegyék jelentös része azonban nem találta elegendőnek a törvényhatósági törvény azon rendelkezését, hogy a szolgabíráknak a törvények és szabályrendeletek által hozzájuk utalt jogokat és kötelezettségeket kell gyakorolniuk, így a továbbiakban e törvényhatóságok hatásköri szabályzatait vizsgálom.

A szolgabíró működése során az alispántól kapta utasításait, és az államigazgatási ügyekben is az alispán közvetítette irányába a kormányzat intézkedéseit. ${ }^{81} \mathrm{~A}$ kormányrendeletek végrehajtása a járásukban a szolgabírák felelőssége volt. ${ }^{862} \mathrm{~A}$ járást vezető tisztségviselő önállóan hozott határozataival szemben szintén az alispánhoz lehetett fellebbezni, majd onnan a belügyminiszterhez lehetett fordulni a törvényhatósági törvény értelmében ${ }^{863} \mathrm{~A}$ szolgabírák emellett jogosultak voltak a törvényhatósági bizottság közgyülésein részt venni, amelyen szavazati joguk is volt.

MÁrKus 1912, 308.; FÉsüs 1880, 64-65.

STIPTA 1998a, 122.

859

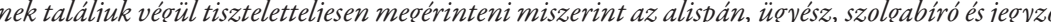
munka körét illetöleg, azért nem dolgoztunk ki tervezetet, mivel a törvényben már kivan jelölve." - MNL BM 117. 17731/1871. - Arad vármegye.

860 MNL BM K150 117. 17803/1871.

861 „[M]iután megyénk közönsége a járási sz[olga]birókat eredetileg is, most is, egymástól függetlennek tervezte, óhajtja, kik egyedül a megyétöl vagy alispántól vegyék meghagyásaikat." -MNL BM K150 118. 31986/1871. - Hont vármegye; Boncz 1876, 128 e).

862 MNL BM K150 117.21272/1871. - Doboka vármegye.

863 MNL BM K150 117.21272/1871. - Doboka vármegye; 22026/1871. - Felső-Fehér vármegye; 233. 28463/1873. - Moson vármegye.
} 
Gömör és Kis-Hont vármegye szolgabírói hivatalára vonatkozó tervezetében részletesen bemutatta, hogy melyek az egy ember erejét meghaladó „föszolgabírói” teendők. ${ }^{864}$ (A vármegye a belügyminisztériumi korrekciót megelőzően a később javított főszolgabírói elnevezést alkalmazta.) Szeptemberben a közmunka és az újoncösszeírás, januárban és februárban pedig a községi, a gyámi számadások és az előköltségvetések vizsgálata jelentős mértékben leterhelte a járási tisztviselőket. Emiatt e hatáskörök felderítésével érdemes megkezdeni a szolgabírák feladatainak vizsgálatát.

\subsection{A szolgabírák katonasággal kapcsolatos teendői}

A véderőtörvény alapján az ország fegyveres ereje a hadseregből, a haditengerészetből, a honvédségből és a népfelkelésből állt. A hadseregnek az Osztrák-Magyar Monarchia mindkét államának megvédése és belső rendjének biztosítása volt a feladata, míg a honvédség a hadsereget támogatta és csupán Magyarországgal kapcsolatos hadi feladatokat látott el. A hadseregbe, a haditengerészetbe és a honvédségbe sorozottakat eltérő kötelezettségek terhelték, így az újoncokat külön válogatták ki az egyes hadtestekbe.

A véderőről szóló 1868:XL. tc. és a hozzá kapcsolódó rendeletek határozták meg a szolgabírák hatásköreit a katonaállítás során. A vármegyékben a járási tisztviselők feladata volt a hadkötelezett korosztályban lévők összeírása a községi elöljárók közreműködésével. Ezt követően szintén a szolgabíráknak kellett lebonyolítani a sorshúzást, amelynek célja meghatározni azt a sorrendet, ami alapján a védkötelezettek a különböző hadtestekbe kerültek. A katonai szolgálattal kapcsolatos beadványok elintézése is a járási tisztviselők hatáskörébe tartozott. Az eljárás e részének megvalósítására sorozójárásonként augusztus 15-e és szeptember 30-a között került sor. ${ }^{865}$

A szolgabíró az alispán, a főorvos és két megbízható személy mellett a közigazgatást képviselte a sorozó bizottságokban mint sorozási előadó. A sorozási bizottságoknak a rendes hadsereg és a honvédség részéről is voltak tagjaik. A legfontosabb feladatuk a besorozandók szellemi és testi képességeinek felmérése volt, valamint ez alapján beosztásuk a különböző hadtestekbe. Emellett e testületek bírálták el a katonai szolgálat alóli felmentéseket. ${ }^{866} \mathrm{Az}$ eljárás e szakaszát január 15 -e és március 15 -e között bonyolították le, a hadseregbe pedig október 1-jével kellett jelentkezni. Az újoncozási teendők olyan fontosságúak voltak a szolgabírák életében, hogy e teendőket az összes törvényhatóság feltüntette szabályzatában. ${ }^{867} \mathrm{~A}$ járást vezető tisztviselőknek nem csupán a sorozási teendők

864 MNL BM K150 118. 23816/1871.

865 84. A magyar királyi honvédelmi ministerium körrendelete.

866 86. A honvédelmi ministerium körrendelete a sorozási ügyről.

867 MNL BM K150 117. 21272/1871. - Doboka vármegye; 22026/1871. - Felső-Fehér vármegye; 21800/1871. - Fogaras vidék; 20826/1871. - Sáros vármegye; 118. 22592/1871. - Bereg vármegye; 32032/1871. - Gömör és Kis-Hont vármegye; 22187/1871. - Közép-Szolnok vármegye; 22326/1871. - Komárom vármegye; 22336/1871. - Veszprém vármegye; 233. 28463/1873. - Moson vármegye. 
voltak az egyedüli katonasággal kapcsolatos hatásköreik. ${ }^{868} \mathrm{~A}$ katonák elszállásolásának és élelmezésének megszervezése, ${ }^{869}$ a szabadságolt katonák, a póttartalékosok, illetve az ideiglenesen és véglegesen rokkantak nyilvántartása, valamint az előfogatokról való gondoskodás is hozzájuk tartozott. ${ }^{870}$ Fogaras vidék emellett kiemelte, hogy a katonai visszaélésekkel szemben a községek megóvása is a szolgabírák kötelessége. ${ }^{871}$

\subsection{A járási lakosság közmunka-kötelezettsége}

A megyei lakosság az adó megfizetése mellett közmunkára is kötelezett volt. A közmunka-összeírásokat szintén szeptember 30-áig kellett benyújtani az alispánnak. A szolgabíró az egyes községekben a községi elöljárók és két hites személy jelenlétében írta össze a fennálló közmunkatartozásokat, ${ }^{872}$ amelyek jegyében a lakosság útfelújítást, a hidak, gátak karbantartását végezte el a megyei mérnök közremüködésével. ${ }^{873}$ Emellett közveszély esetén a veszély elhárítására is igénybe vehették a közmunka-kötelezettek munkáját. A közmunkát pénzben is megválthatták ${ }^{874} \mathrm{~A}$ kötelezettség végrehajtása a szolgabírák feladata volt a közmunkák szabályozásáról szóló 1844:9. tc. értelmében. Ezt a feladatkört szintén az összes törvényhatóság feltüntette a hatáskörről szóló rendeletében. ${ }^{875} \mathrm{Az}$ ehhez kapcsolódó feladatok elvégzése érdekében Doboka, Sáros, Veszprém, Közép-Szolnok, Hunyad és Moson vármegye a szolgabírákra bízta a községi közlekedési utak felügyeletét és karbantartását, amelyben a községi elöljáróságok segítették. ${ }^{876} \mathrm{~A}$ szolgabíró az utak karbantartása miatt Doboka, Felső-Fehér, Sáros, Bereg, Komárom és Közép-Szolnok vármegyében az útibiztosokkal is szoros kapcsolatban volt. ${ }^{877}$ Közép-Szolnok és Doboka vármegyében emellett kötelesek voltak havonta a közmunka eredményéről az alispánnak jelentést tenni. ${ }^{878}$ Sáros vármegye önálló intézkedési jogot biztosított a szolgabírák 
számára az egyes építkezésekre vagy javításokra 50 Ft-nyi költségvetési összeg erejéig az alispánnak történő utólagos jelentéstételi kötelezettség mellett. ${ }^{879}$

\subsection{A községek és a szolgabírák kapcsolata}

A szolgabírói hatáskörök legnagyobb csoportja az 1871:XVIII. tc. alapján, valamint az 1870. évi XLII. tc. 61. \$ második fordulata szerint a községekhez kapcsolódott. A két törvény a szolgabírák szerepét a községekkel szemben csupán a felügyeletre szorította. A községi törvény három településtípust különböztetett meg: a kisközséget, a nagyközséget és a rendezett tanácsú várost. A szolgabírák hatásköre a kisközségekre és a nagyközségekre terjedt ki, ${ }^{880}$ mivel a rendezett tanácsú városok önállóan látták el azokat a feladatokat, amelyeket a járást vezető tisztségviselők végeztek a többi településen. A járást vezető tisztviselők legfőbb szerepe az alispán (a törvényhatóság) és a nagy- és kisközségek közötti közvetítés volt.

Nehrebeczky Sándor miniszteri tanácsos a községi törvény országgyülési vitája során a szolgabíró gyámkodásaként definiálta ezt a tevékenységet, amelyet véleménye szerint határozottan igényelnek a községek. ${ }^{881}$ A törvény megszületése előtti állapotokat vizsgálva a községek számára ez óriási előrelépést jelentett, mert ezt megelőzően körvonalazható autonómiával nem rendelkeztek. Ennek jegyében kerülhetett a községekhez elöljáróiknak választási joga, amely ezt megelőzően a szolgabírák kijelölési jogához kötött volt. Ezt Tóth Vilmos belügyminiszter emelte ki felszólalásában a Képviselőház 1871. március 22-ei ülésnapján. A korábbi állapotokat a következőképpen vázolta: „A mi pedig a községek belügyeit illeti, azok autonómiája mindnyájunk tudomása szerint, oly csekély volt, hogy az egész autonómiát tulajdonképen e két szóban lehetett összefoglalni: szolgabirói hatalom." 882

A járást vezető tisztviselők hangsúlyos jogköröket kaptak az 1871:XVIII. tc.-ben a községi önkormányzati testületek létrehozatalában. A szolgabírák a községek képviselö-testületének összeállításában vállaltak jelentős szerepet. E testületi szervek fele részben virilis (a legtöbb egyenes állami adót fizetők), fele részben választott tagokból álltak össze. ${ }^{883}$ A járást vezető tisztviselők kötelezettsége a virilisek névjegyzékének kiigazítása volt. A képviselők választása során pedig kitűzték a választás időpontját, és választási elnökökként lebonyolították azt. ${ }^{884} \mathrm{~A}$ választások jogszerűségét ellenőrző igazolóválasztmányok elnökei járásuk községeiben szintén a szolgabírák voltak, amelybe két tagot a képviselö-testület választott saját tagjai közül, a szolgabíró pedig szintén két tagot nevzhetett ki a községi képviselők közül. Ezáltal biztosították a szolgabíró túlsúlyát a választmányban. A községi

879 MNL BM K150 117.20826/1871. - Sáros vármegye.

880 „Ezekhez képest hatáskörükhöz tartoznak [a szolgabiráknak]: a.) a kis és nagy községekre való közvetlen felügyelet." - MNL BM K150 118. 22592/1871. - Bereg vármegye.

881 KN 1869. XV.k. 131.

882 KN 1869. XV.k. 149.

883 HeNCZ 1973, 106.

884 TAKÁCS 1963, 29. 
választások során ezzel még nem ért véget a szolgabírói gyámkodás, mivel a községek első képviselö-testületi ülését is ő hívta össze a választás lebonyolítása után. Emellett pedig közremúködtek a tisztújító szék alkalmával is, amelyen a községi elöljárókat választották. E vezető tisztviselöket az összes választásra jogosult lakos választotta, amelynek lebonyolítását szintén a szolgabíró koordinálta (időpontjának kitűzése, a választás kihirdetése és vezetése, a rend fenntartása). A szolgabírónak a község törvényes működése miatt különösen jelentős községjegyzői és körjegyzői tisztség betöltése kapcsán további jogosultságai voltak, ugyanis ezen állomásokra a nyilvános pályázat kiírása és annak kihirdetése szintén a szolgabíró feladata volt. A körjegyzők választása esetén szintén a szolgabíró elnökölt a szövetkezett községek képviselőinek a körjegyzőség székhelyén tartandó ülésén. A körjegyzőséget fenntartó települések esetén a rendeleteket a szolgabíró a körjegyzőnek küldte meg, aki azt a község bírájával együttesen vagy annak jóváhagyása mellett hajtotta végre. Ennek értelmében érthető, hogy az állami közigazgatás közvetítésében helyi szinten döntő szerepet betöltő községjegyzői és körjegyzői pozíciók tekintetében különösen erős hatásköröket rendelt a törvény a szolgabíróhoz.

A községi törvény a községi elöljárók fegyelmi felelősségéről is rendelkezett, ${ }^{885}$ amely szerint felettük a felügyelet és az ellenőrzés jogát nagy- és kisközségekben a képviselö-testület és a szolgabíró gyakorolhatta. ${ }^{886} \mathrm{~A}$ felelősségre vonási eljárás a vizsgálattal vette kezdetét, amit a kis- és nagyközség esetében a község belügyeit érintő kötelességszegések esetén a képviselő-testület rendelhetett el. Az állam érdekeinek sérelme okán viszont a szolgabíróhoz tartozott e jogosultság. Ilyen sérelem abban az esetben volt megállapítható, ha valamely községi elöljáró megsértette vagy hanyagul teljesítette a törvényben vagy a szabályrendeletekben megszabott feladatait. Emellett akkor is kezdeményezhették a felelősségre vonást, ha a községi elöljáró a törvényhatóság, illetve a kormány által még helyben nem hagyott, vagy megváltoztatott olyan határozatot vagy szabályrendeletet hajtott végre, amely még felsőbb jóváhagyásra várt. A képviselő-testület által megindított vizsgálatot a vizsgálóbizottság, míg a szolgabíró által elrendeltet az általa megbízott személy folytatta le, ${ }^{887}$ amelyröl a képviselő-testületet azonnal értesíteni kellett. A vizsgálat elrendelése esetén a szolgabíró felfüggeszthette a vétkes hivatalnokot, és helyettesítéséröl intézkedhetett. ${ }^{88} \mathrm{~A}$ szolgabíró szükség esetén saját közegeivel a rendelet elmulasztott végrehajtását pótolhatta, amelynek következtében a föispán kivételes jogköréhez hasonló jogosultság illette meg őt a községekben. ${ }^{889} \mathrm{~A}$ vizsgálat eredményének függvényében a szolgabíró jogosult volt a tiszti keresetet megindítani a kis- és nagyközségek esetében, amelynek lefolytatása e községeknél a törvényhatóság tiszti ügyészének kötelessége volt. A tiszti keresetet az illetékes magyar királyi törvényszék bírálta el. Ha a hivatalnok cselekménye nem minősült bủncselekménynek, akkor dorgálással, pénzbírsággal vagy hivatalvesztéssel sújthatták.

\footnotetext{
885 KÉRÉSZY 1942, 294.

886 SARLós 1976, 102.

887 Csizmadia 1976, 132-133.

888 Az 1886:XXI. tc. felelősségi szabályozása is hasonló szakaszokból épült fel, így jól szemlélteti az eljárás lefolyását: SALLAI 2020b, 62-64.

889 Stipta 1995a, 301.; Varga 2018, 194.
} 
A járást vezető tisztviselő emellett bizonyos vármegyékben járási számvevő hiányában átvizsgálta a községek által elfogadott költségvetéseket, és a hiányok pótlására is felhívta a községeket mielőtt a törvényhatósági bizottság elé kerültek volna jóváhagyásra ${ }^{890}$ Ezek jóváhagyását a törvényhatósági bizottság csak akkor tagadhatta meg, ha az a törvényben meghatározott feltételeknek nem felelt meg, vagy a kiadásokat községi adóból fedezték, vagy ha valamely adófizető a költségvetéssel szemben panasszal élt. A községnek ebben az esetben a szolgabíró útmutatásainak figyelembevételével kellett új költségvetést készítenie.

A járást vezető tisztviselők tehát a kis- és nagyközségek működésében hasonló szerepkört töltöttek be, mint a föispán és a belügyminisztérium a törvényhatóságokéba. A rendi korszakban az alsófokú közigazgatási teendőket a szolgabíró a községek közremüködésével a földesúr támogatása mellett végezte. ${ }^{891} \mathrm{~A}$ jogegyenlőség megteremtésével 1848-ban a községek feletti földesúri hatalom megszűnt, így szükségesnek tartották, hogy a szolgabíró továbbra is segítse a községek mủködtetését.

A községekkel kapcsolatos kötelességek a legtöbb vármegye hatásköri szabályzatában megjelentek a szolgabírák kapcsán. ${ }^{892} \mathrm{~A}$ legrészletesebben e hatásköröket Fogaras vidék fejtette ki: „[A] szolgabiró felügyel a hatosága alatt állo községekre, vezeti azok szervezését, képviseleti tagjai 's hivatalnokai megválasztatását's a megválasztott hivatalnokokat a törvény által kiszabott idöre, megerösiti, felügyel továbbá a törvény korlátai közt a községek közigazgatása, közrendészete, gazdászata, törvénykezése és az adó behajtására; a hanyag és rendeleteket megszegö községi hivatalnokokat felfüggeszti állomásukból elmozditja 's a végleges határozat hozataláig mások által helyettesiti." 893

A községi törvény csupán azt szabályozta, hogy a kormányrendeletek végrehajtásáért a kis- és nagyközségekben a bírák és a községjegyzők lesznek felelösek. Fogaras vidék ehhez hozzátette, hogy a szolgabíró felügyeli az állami közigazgatás érvényesülését a községekben, így ellenőrizve a tisztviselők munkájátt. ${ }^{894} \mathrm{Ez}$ logikus következménye volt annak, hogy a szolgabírák voltak jogosultak a községi elöljárósággal szembeni felelősségrevonási eljárás megindítására.

\subsection{A szolgabíró szerepe az adók beszedésében}

A kiegyezést követően került sor a modern magyar adórendszer kiépítésére is. Az 1868:XXI. tc. rendelkezett a közadókkal kapcsolatos eljárásokról. Az adók kivetésében az adóhivatalok mellett a törvényhatóságok és a községi elöljárók is részt vettek. Az

890 MNL BM K150 118. 22592/1871. - Bereg vármegye; 233. 28643/1871. - Moson vármegye.

891 DoBSZAY 2015, 1055-1056.

892 MNL BM K150 117.21800/1871. - Fogaras vidék; 118. 22592/1871. - Bereg vármegye; 32032/1871. - Gömör és Kis-Hont vármegye; 23891/1871. - Hunyad vármegye; 22187/1871. - Közép-Szolnok vármegye; 22326/1871. - Komárom vármegye; 22336/1871. - Veszprém vármegye; 233.28463/1873.

- Moson vármegye.

893 MNL BM K150 117.21800/1871.

894 MNL BM K150 21800/1871. 
egyénekre lebontott összeget főszabály szerint önkéntesen kellett megfizetnie az adózónak a községi adóhivatal, az adószedők vagy a községi elöljárók számára. A szolgabírák a törvény alapján az adóhátralékok behajtásában vettek részt, amelyet az adóhivatalok által megküldött kimutatások alapján végeztek el. ${ }^{895}$ Elöször a községi elöljárók segítségével megintették a hátralékos adókötelezetteket adófizetési kötelezettségük önkéntes teljesítése céljából. A pénzügyi tisztviselő a végrehajtást a szolgabíró közreműködésével végezte, aki a törvényhatóságot képviselte az eljárás során. Emellett a lefoglalt vagyontárgyak árverésének kihirdetése is a szolgabíró kötelessége volt.

Az októberi diplomát követően az adóigazgatási teendőket leválasztották a vármegyékről, így jelentős változást hozott, hogy a kiegyezést követően a kormányzat ismételten bevonta a törvényhatóságokat az adózással kapcsolatos eljárásba ${ }^{896}$ Már az 1867. május 23-án kelt pénzügyminiszteri rendelet felhívta a törvényhatóságokat, hogy a tisztviselők támogassák a magyar királyi pénzügyi felügyelőségeket munkájukban ${ }^{897}$ A minisztérium a vármegyéktől a járásbeli tisztviselőknek a magyar királyi adóhivataloknak nyújtandó segítségre való utasítását kérte. ${ }^{898} \mathrm{Az}$ 1868:XXI. tc. által vázolt szolgabírói szerepvállalás az adók behajtásában a vármegyék hatásköri szabályzatában is megjelent. ${ }^{899}$ Doboka vármegye és Fogaras vidék az ezzel kapcsolatos hatásköröket akképp bővítette, hogy járási tisztviselöik az adók összeírásában is részt vettek, valamint felügyelték az adószedők és a községi elöljárók munkáját, amelyről évnegyedenként jelentést tettek az alispánnak (Doboka vármegyében az alkapitánynak). Az évnegyedenkénti időtartam meghatározására amiatt került sor, mert az évi adót négy egyenlő részletben kellett megfizetni. Doboka, Felső-Fehér és Közép-Szolnok vármegye pedig az adó mérséklésére elemi csapások miatt beadott kérelem esetén a helyszíni szemlét utalta a szolgabírákhoz..$^{900} \mathrm{~A}$ községi adókat is az országos adókkal megegyezően kellett beszedni, így Veszprém vármegye beemelte ezt is a szolgabírák hatáskörébe. Külön megjelölték, hogy e háziadóból fedezték a községek a tanítók és a lelkészek fizetéseit. ${ }^{901}$

\subsection{A közbiztonság fenntartása a járásokban}

A mezei rendőrségről szóló 1840:9. tc. a szolgabírák hatáskörébe utalta a különböző mezőgazdasággal és iparral kapcsolatos településen kívüli károkozásokat, amelyek feletti

\footnotetext{
895 Boncz 1876, 128 e).

896 SZITA 1980, 385-388.

897 STIPTA 2013, 22-23.

898 58. A m. k. pénzügy ministerium rendelete az adóbehajtásról 146.

899 MNL BM K150 117. 21272/1871. - Doboka vármegye; 22026/1871. - Felső-Fehér vármegye; 21800/1871. - Fogaras vidék; 118. 22592/1871. - Bereg vármegye; 32032/1871. - Gömör és KisHont vármegye; 22187/1871. - Közép-Szolnok vármegye; 222326/1871. - Komárom vármegye; 2336/1871. - Veszprém vármegye; 233. 28463/1873. - Moson vármegye.

900 MNL BM K150 117.21272/1871.; 22026/1871.; 118. 22187/1871. - Közép-Szolnok vármegye.

901 MNL BM K150 118. 22336/1871.
} 
felügyelet és bíráskodás illette meg őket. ${ }^{902}$ Ezekben az ügyekben elsősorban $12 \mathrm{Ft}$ alatti kártétel esetén a községi elöljáróság bíráskodott, ha ezt elmulasztották, akkor a járást vezető tisztviselők jártak el. Emellett a szolgabírákhoz lehetett fellebbezni, valamint a nemesek ügyeiben kizárólag ők járhattak el. ${ }^{903} \mathrm{Az}$ áprilisi törvények azonban kimondták a törvény előtti egyenlőséget, míg az 1869:IV. tc. elválasztotta a közigazgatást és az igazságszolgáltatást. Emiatt több kétség is felmerült a törvény alkalmazása kapcsán.

Bereg, Komárom, valamint Gömör és Kis-Hont vármegye a mezei rendőrségi ügyekben való eljárást meghagyta a szolgabírák hatáskörében, ha a cselekmény bünvádi eljárásra vagy kártérítésre nem jelent jogalapot, és így nem a rendes bírósághoz tartozik. ${ }^{904}$ Bereg vármegye és Csongrád vármegye azt kérelmezte az igazságügyminisztériumnál, hogy ezekben az ügyekben továbbra is a közigazgatási tisztviselők járhassanak el. ${ }^{905}$ Veszprém és Moson vármegye szintén azokat a mezei rendőrségi ügyeket hagyta meg a szolgabíráknál, amelyek nem a törvénykezési szerveket illették. ${ }^{906}$ Moson vármegye kiemelte, hogy csupán fegyelmi vagy bírságolási tevékenységet végezhetnek a szolgabírák. Emellett megkísérelhettek egyezséget létrehozni a felek között, ha ez sikertelen volt, akkor rendes bírósághoz kellett őket utasítani. Felső-Fehér vármegye pedig úgy határozott, hogy a szolgabíró köteles a mezei rendőri szabályok megtartása felett őrködni, és az esetleges kártételeket kinyomozni. A járást vezető tisztviselő e törvényhatóságban csak a bizonyítékok összegyűjtésében, valamint a vizsgálóbíró és a szakértő orvos értesítésében vett részt. A büntetőbíróság ügyeiben a tanúvallomások felvételében sem müködhetett közre. ${ }^{907}$ Doboka vármegye viszont fenntartotta azt, hogy a szolgabírák mindaddig teljeskörüen eljárhatnak a mezei rendőrségi ügyekben, amíg kormányrendelet vagy törvény másképpen nem rendelkezik..$^{908}$

Emellett a közbiztonság megőrzését is feladatukként határozták meg a vármegyék, ${ }^{909}$ így a mezei rendőrségi ügyeken kívül a kihágások esetén is eljártak. ${ }^{910} \mathrm{~A}$ járási tisztviselők

902 BATó 2010, 28.

903 ZsOLdos 1842c, 17-20.

904 MNL BM K150 118. 22592/1871.; 22326/1871.; 32032/1871.

905 „A mezei és hegy rendörség fontosságát kello" figyelemre méltatva, az alválasztmány szükségét látja, 's inditványba hozza, hogy irjon fel a megye az igazságügyministerhez miként terjesszen az országgyülés elé törvényjavaslatot arról, hogy a mezei rendörségi ügyek a mostani czélszerütlen felosztás megváltoztatása mellett általában tehát azok feletti biráskodás is a szolgabirák hatáskörébez utasittassanak." - MNL BM K150 118. 22592/1871. - Bereg vármegye; 117.21068/1871. - Csongrád vármegye. MNL BM K150 118. 22336/1871.; 233.28463/1873. - Moson vármegye.

MNL BM K150 117.21272/1871.

MNL BM K150 118. 22592/1871. - Bereg vármegye; 22187/1871. - Közép-Szolnok vármegye; 30937/1871. - Moson vármegye; 22336/1871. - Veszprém vármegye; „Azállam hatalom, s hatoságainak tekintélyét, ugy a törvényes állami szervezet biztonságáért kötelessége felügyelni; járásában folytonos gondot forditván a vagyon s. személy biztonság állandó fenntartására - illetöleg biztositására; melynek eshetö meg zavarása esetén rögtön jelentést tész az alispánnak, skiszálva abely szinére a rendelkezése alatti törvényes eszköző́kkel köteles saját felelöségére, fel zavart rendet, nyugalmat helyre állitani." - 117.21272/1871. Doboka vármegye; 22026/1871. - Felsö-Fehér vármegye; 20826/1871. - Sáros vármegye.

910 MNL BM K150 117. 21272/1871. - Doboka vármegye; 20826/1871. - Sáros vármegye; 118. 23891/1871. - Hunyad vármegye. 
feladata a rendőri kihágások megakadályozása és azok elkövetőinek megbüntetése volt, valamint a bünelkövetők után nyomoztak és körözték őket, sikeres elfogásuk esetén pedig az illetékes bíróság elé kísérésük is a szolgabírákra hárult. A szolgabírák közbiztonsági feladatai ezen kívül a következők voltak: a járásukban a vásárok felügyelete, az idegen koldusok és kóborlók visszakísértetése a községi illetőségüknek megfelelő településre, illetve az igazolási jegyek és útlevelek láttamozása. ${ }^{911}$ Doboka vármegye emellett a szolgabíró számára jogot biztosított arra, hogy olyan gyüléseket vagy mozgalmakat betiltson, amelyek a tulajdon jogtalan megtámadására, vagy a fennálló alkotmányos rend erőszakos megváltoztatására irányulnak. ${ }^{912}$ Fogaras vidéken a községi elöljáróságok rendőri ügyekben hozott határozatai elleni fellebbezéseket is elbírálta. ${ }^{913}$ Csongrád vármegye a közbiztonság fenntartására irányuló feladatok közül a pásztorok névjegyzékének a csendbiztosok segítségével történő összeírását emelte ki, akiknek felelősségre vonása szintén az ő kötelezettségük volt. ${ }^{914}$ Komárom vármegye a vízirendőrséggel kapcsolatos ügyeket is a hatáskörükbe sorolta. ${ }^{915}$ Doboka, Közép-Szolnok, Hunyad és Moson vármegye pedig a községi erdőkben az erdészeti szabályok feletti felügyeletet és a kihágások felderítését is a szolgabírákhoz utalta. ${ }^{916} \mathrm{~A}$ legrészletesebb szabályzatot készítő Doboka vármegye szintén ebbe a körbe sorolta a jogosulatlan fegyverhasználatot és a mészárszékek, kocsmák mértékeinek felügyeletét, valamint azt, hogy a tartózkodásuk célját és létfenntartásuk módját igazolni nem tudó idegeneket, illetve a kuruzslókat és „a népnyugalmat megzavaró ámítókat" kitoloncoltathatta a szolgabíró. A közbiztonság megőrzése céljából kellett a járásukban a vallásszabadságot is biztosítaniuk. ${ }^{917}$

A mezei rendőrségi ügyeknél ritkábban előforduló, de ugyanúgy a közigazgatás és az igazságszolgáltatás elválasztása miatt problémás kérdés volt a vásárbíráskodás, amelyet a polgári törvénykezési rendtartás tárgyában hozott 1868:LIV. tc. a szolgabírák és az esküdtek törvénykezési fóruma elé utalt a nagy- és kisközségek esetében. Az esküdti pozíció azonban megszűnt az 1870:XLII. tc. hatálybalépésével. Felső-Fehér és Doboka vármegye így hatásköri szabályzatában a szolgabírák feladatai között meghagyta, hogy egyesbíróként a vásári ügyekben eljárjanak az 1868:LIV. tc. értelmében. ${ }^{918}$ A szolgabírák az országos és heti vásárok alatt az azzal összefüggő adóssági és adásvételi szerződésekkel kapcsolatos jogvitákban ítélkeztek e jogkörükben. Szintén a közigazgatás és az igazságszolgáltatás elválasztásával nehezen összeegyeztethető, hogy Doboka vármegye a becsületsértési ügyek elbírálását első fokon a szolgabírákhoz utalta. ${ }^{919}$

\footnotetext{
MNL BM K150 117.21800/1871. - Fogaras vidék.

MNL BM K150 117.21272/1871. - Doboka vármegye.

MNL BM K150 117.21800/1871.

MNL BM K150 117.21068/1871.

15 MNL BM K150 118. 22326/1871.

916 MNL BM K150 117.21272/1871.; 118. 22187/1871.; 23891/1871.; 233. 28463/1873.

917 MNL BM K150 117.21272/1871.

918 MNL BM K150 117.21272/1871.; 22026/1871.

919 MNL BM K150 117.21272/1871.
} 


\subsection{A nem országos jelleggel előforduló szolgabírói hatáskörök}

A községekben előforduló iparügyekben az elsőfokú eljárás lefolytatása ${ }^{920}$ és az iparjegyek kiállítása szintén a szolgabírák feladatai közé tartoztak a törvény hatálybalépését követően. ${ }^{921}$ Fogaras vidék és Sáros vármegye a neoabszolutizmus időszakából származó 1859. december 20-án kelt 227. számú nyílt parancsból származtatta a szabad ipar gyakorlására az engedélyek kiadásának jogosultságát, ${ }^{922}$ amely alapján nyilvántartást vezettek a járásukban található kereskedőkről, gyárosokról és kézművesekről ${ }^{923}$ Doboka vármegye emellett a szolgabírák számára biztosította a királyi kisebb haszonvételek engedélyezését. ${ }^{924}$

Az árva- és gyámhatóság gyakorlását az 1870:XLII. tc. megtartotta a törvényhatóságoknál, amely munkálatok elvégzésére az árvaszéket rendelték. Az árvaszék egy elnökből, két ülnökből, a tiszti ügyészből, a számvevőből, egy jegyzőből és a szavazattal nem rendelkező közgyámból állt. A vármegyék jelentős részében így az árvaszéki végzéseket a szolgabírák hajtották végre. ${ }^{925}$ Komárom vármegye emellett a szolgabírákra ruházta a vármegyét megillető felügyeleti jogot az árvák ügyei felett, akiknek az alispán irányában állt fenn jelentéstételi kötelezettségük. Több törvényhatóság a járási közgyámi tisztség rendszeresítését mellőzte, így Kővár vidéken és Moson vármegyében a szolgabíró, míg Aranyosszék esetében a dulló látta el e hivatalnok feladatait. Hozzájuk hasonlóan végül Komárom vármegyében is ez a megoldás született, mivel a belügyminisztérium nem engedélyezte a járási közgyámi állomások felállítását. ${ }^{926} \mathrm{Ez}$ a megoldás a neoabszolutizmus korának szabályozásával is összhangban állt. ${ }^{927}$

A szolgabírák kötelessége volt számos törvényhatóságban a közjólét érdekében tevékenykedni. ${ }^{928}$ A népiskolai közoktatás tárgyában elfogadott 1868:XXXVIII. tc. értelmében a tanköteles diákokat az iskolába járástól távoltartó szülővel szemben bírság volt kiszabható, az ezzel kapcsolatos fellebbezéseket szintén a szolgabíró bírálta el. ${ }^{929}$ Közép-Szolnok vármegye az iskolákkal kapcsolatban szélesebb hatáskört biztosított, mivel a községi

Boncz 1876, $128 \mathrm{e})$.

MNL BM K150 117. 21272/1871. - Doboka vármegye; 22026/1871. - Felső-Fehér vármegye; 21800/1871. - Fogaras vidék; 118. 22592/1871. - Bereg vármegye; 32032/1871. - Gömör és Kis-Hont vármegye; 22187/1871. - Közép-Szolnok vármegye; 22326/1871. - Komárom vármegye; 22336/1871.

- Veszprém vármegye; 233. 28463/1873. - Moson vármegye.

922 227. Kaiserliches Patent vom 20. December 1859, 619-650.

923 MNL BM K150 117.21800/1871.; 20826/1871.

924 MNL BM K150 117.21272/1871.

925 MNL BM K150 117. 20171/1871. - Aranyosszék; 20826/1871. - Sáros vármegye; 118. 22592/1871. Bereg vármegye; 32032/1871. - Gömör és Kis-Hont vármegye; 22499/1871. - Kövár vidék; 22326/1871. - Komárom vármegye; 22336/1871. - Veszprém vármegye; 233. 28463/1873. - Moson vármegye. MNL BM K150 118.34064/1871.

927 Номокi-Nagy 2019, 49-50.

928 MNL BM K150 117.21272/1871. - Doboka vármegye; 21800/1871. - Fogaras vidék.

929 MNL BM K150 117. 21272/1871. - Doboka vármegye; 22026/1871. - Felső-Fehér vármegye; 21800/1871. - Fogaras vidék. 
és a felekezeti iskolák, valamint a felnőttoktatás alakítására és fenntartására felügyelt a szolgabíró, aki erről jelentést tett az alispánnak. ${ }^{930}$ Doboka vármegyében ezenkívül a szolgabíró felügyelte a munkatehetetlen, segélyezésre szoruló szegényekkel szembeni gondoskodást. Ha erre nem volt képes a település, akkor jelentést tett az alispánhoz. ${ }^{931}$ Felső-Fehér vármegye esetében a kereskedő vagy iparos és segédei, illetve a gazda és cselédei közötti jogviták kapcsán felmerült panaszokat a járást vezető tisztviselők a vármegye 1868. évi cselédrendtartása szerint intézték el. ${ }^{932}$ Doboka és Moson vármegye szintén a szolgabírák feladatául szabta, hogy az aratókkal, cséplőkkel, egyéb munkásokkal, illetve a cselédekkel kötött szerződések körüli jogvitákat rendezzék. ${ }^{933}$

A szolgabírák felügyeltek a közegészségügyi és állategészségügyi viszonyokra is, így éhínség, ragályos megbetegedések vagy marhavész esetén a megfelelő intézkedéseket kellett megtenniük. Ezt követően pedig a járási orvost vagy az állatorvost értesítették. ${ }^{934}$ A beteg marhák elkülönítése nem csupán a hatásköri szabályzatok, hanem a mezei rendőrségi törvény alapján is kötelessége volt a járást vezető tisztviselőknek.

Erdély területén problémát jelentett a neoabszolutizmus rendeleteinek hatályban tartása a kiegyezést követően, ugyanis több törvényhatóság ezek alapján kihágási ügyekben megállapította szolgabíráinak hatáskörét. Az osztrák büntetőtörvénykönyv alapján kisebb jelentőségű büntetőügyekben, ${ }^{935}$ az 1852. évi erdőtörvény alapján kihágási ügyekben ${ }^{936}$ és mezei rendőrségi ügyekben járhattak el a járást vezető tisztviselők bizonyos vármegyékben. ${ }^{937}$

Aranyosszék, Fogaras vidék és Felső-Fehér vármegye egy 1869. évi belügyminiszteri rendelet folytán a jobbágyfelszabadításból hátramaradt vitás kérdések, így elsősorban a közös tulajdonú legelők és erdők, valamint a közbirtokosságok rendezését a járást vezető tisztviselőkhöz utalta. ${ }^{938} \mathrm{Az} 1858$. évi építési rendtartás értelmében az építkezések

\footnotetext{
930 MNL BM K150 118. 22187/1871. - Közép-Szolnok vármegye.

931 MNL BM K150 117.21272/1871.

932 MNL BM K150 117.22026/1871.

933 MNL BM K150 117.21272/1871.; 118.30937/1871.

934 MNL BM K150 117.21272/1871. - Doboka vármegye; 22026/1871. - Felső-Fehér vármegye; 118. 22187/1871. - Közép-Szolnok vármegye; 22336/1871. - Veszprém vármegye.

935 88. Kaiserliche Verordnung vom 20. Juni 1858.383-388.; MNL BM K150 117.21272/1871. - Doboka vármegye; 22026/1871. - Felső-Fehér vármegye, 21800/1871. - Fogaras vidék.

936 250. Kaiserliches Patent von 3. December 1852. 1053-1080.; MNL BM K150 117. 21800/1871. Fogaras vidék.

937 28. Verordnung der Ministerien des Innern und der Justiz vom 30. Jänner 1860. 59-66.; MNL BM K150 117.21800/1871. - Fogaras vidék.

938 „Az 1869. Mártius hó 14-én 963. eln. szám alatt kelt Belügy ministeri rendelet folytán az urbéri ügyekben és az urbéri viszonyokból eredo" a volt urbéresek és volt földesurak között felmerülö legeltetési és faizási joggyakorlatot illetö ügyekben a tényleges állapot felett, vagy szintén a hátralékos szolgálmányok és a hátralékos malom taksák behajtása tárgyában, továbbá korcsmáltatási jog gyakorlata felett a volt urbéresek és regaletulajdonosok vagy ezen utobbiak között felmerült egyenetlenségek, nemkülönben korcsma arányositása és legelö szabályozásoknál felmerült vitás kérdésekben, melyekben eddig elsö hatóságilag az alkapitány müködött, ezennel tehát a fennemlitett ügyek elintézése a szolgabirákra ruháztatik át." - MNL BM K150 117. 21272/1871. - Doboka vármegye; 21800/1871. - Fogaras vidék; 22026/1871. - Felső-Fehér vármegye; 20171/1871. - Aranyosszék; 118. 22187/1871. - Közép-Szolnok vármegye.
} 
helyszíni vizsgálata és azok engedélyezése, valamint a községi középítkezéseknek és az iparüzletek építésének a véleményezése is a szolgabírákhoz tartozott. ${ }^{939}$

Sáros vármegye hatásköri szabályzatában egyedülálló feladat jelent meg, mivel ez alapján a szolgabírák eljártak a járásuk területén felmerülő határmegújítási (reambulatio metarum) ügyekben. ${ }^{940} \mathrm{~A}$ legkülönlegesebb feladatot azonban Közép-Szolnok vármegye határozta meg hatásköri szabályzatában, a szolgabíráknak ugyanis az országos statisztikai hivatalok hiányában minden év utolsó közgyűlésén jelentést kellett tenniük a járásuk területén termett gabona és takarmány mennyiségéről, valamint a régészeti, történelmi és néprajzi tekintetben kiemelkedő leletekről és eseményekről. ${ }^{941}$

Emellett megjelentek az általános jellegü meghatározások is, így a szolgabírák feladata volt járási szinten a "közgyülési határozatok és alispáni rendeletek végrehajtása." ${ }^{42} \mathrm{~A}$ járást vezető tisztviselő az alispáni intézkedésekkel szemben felmerült nehézségek vagy akadályok esetén kifejezhette aggályait az alispán irányába. Ha az alispán fenntartotta azt, akkor a szolgabíró köteles volt végrehajtani, de ezért az alispánnak kellett vállalnia a felelősséget. ${ }^{943}$ A szolgabírák kézbesítették bizonyos vármegyében a hivatalos iratokat. ${ }^{944}$ Felsö-Fehér és Doboka vármegye részletesen megszabta ennek módját, miszerint az átvétel tényét aláirásával kellett igazolnia a címzettnek a kézbesítés idejének feltüntetése mellett. Írástudatlan címzett esetén pedig a kézbesítő tisztviselőnek az irat tartalmát is meg kellett magyaráznia. A szolgabírákat emellett kötelezték, hogy meghatározott időközönként (évnegyedenként) utazzák be a járásukhoz tartozó községeket. ${ }^{945}$ Felső-Fehér vármegye megszabta azt is, hogy ilyenkor köteles a községi pénztárakat megvizsgálni, az iskolákat meglátogatni, valamint a tűzoltó társulatok és tűzoltószerek működéséről személyesen meggyőződni. Erről pedig az alispánnak jelentést kellett benyújtania. ${ }^{946}$

\subsection{A szolgabírák szerepe a törvényhatóságok életében}

Az ismertetett szolgabírói hatáskörök alapján kijelenthető, hogy a járást vezető tisztviselők az alsó középszint általános hatáskörü közigazgatási szervei voltak, ${ }^{947}$ akik szoros

\footnotetext{
939 MNL BM K150 117. 22026/1871. - Felső-Fehér vármegye; 21800/1871. - Fogaras vidék.

940 MNL BM K150 117.20826/1871. - Sáros vármegye.

941 MNL BM K150 118. 22187/1871.

942 MNL BM K150 117.21272/1871. - Doboka vármegye; 22026/1871. - Felső-Fehér vármegye; 118. 22592/1871. - Bereg vármegye; 32032/1871. - Gömör és Kis-Hont vármegye; 233. 28463/1873. Moson vármegye.

943 MNL BM K150 117.21272/1871. - Doboka vármegye.

944 MNL BM K150 117.21272/1871. - Doboka vármegye; 22026/1871. - Felső-Fehér vármegye.

945 MNL BM K150 117. 21272/1871. - Doboka vármegye; 22026/1871. - Felső-Fehér vármegye; 118. 22592/1871. - Bereg vármegye; 22187/1871. - Közép-Szolnok vármegye; 233. 28463/1873. - Moson vármegye.

946 MNL BM K150 117.22026/1871.

947 „A szolgabiráknak a 615-ban körülirt teendöin kivül hatáskörük alatt maradnak mind azon ügyek, melyeket eddig a törvény és szabályrendeletek a szolgabirói hatáskörböz utasitottak, smelyek az ujabb törvények vagy
} 
egységben jártak el a közigazgatást vezető alispánnal. A legfontosabb hatásköreik megmaradtak a rendi korszakból, amelyeket egységesen szabályoztak a törvényhatóságok. Az e kérdésben meglévő egyetértést jól példázza, hogy Szentkirályi Móric a közigazgatás átszervezéséről 1867-ben megjelent munkájában szintén a községek feletti felügyeletet tartotta a szolgabírák legfontosabb feladatának, amelyben még szorosabb ellenőrzési jogköröket kívánt volna. Emellett szintén az adók behajtásában, a közmunkák lebonyolításában, az utak karbantartásában és a közegészségi állapotok feletti felügyeletben szánt szerepet a járási tisztviselőknek. ${ }^{948}$

A szolgabírák hatásköre azonban a törvénykezési feladatok elvesztése ellenére is igen tág maradt. Ez annak is volt köszönhető, hogy több törvényhatóság figyelmen kívül hagyta az első folyamodású bíróságok rendezéséről szóló 1871:XXXI. tc. 15. §-át, miszerint a szolgabírák által ellátott törvénykezési teendők a járásbíróságokhoz kerülnek. Emiatt törvényellenesen a szolgabíráknál tartottak bizonyos bíráskodási jogköröket. Emellett a vármegyék hatásköri szabályozásánál is kitűnik az a probléma, hogy a kiegyezést követően, különösen Erdélyben, nem volt egyértelmü, hogy mely jogszabályok vannak hatályban. A szolgabírák hatáskörét pedig ezenkívül parttalanná tette, hogy a vármegyék nem törekedtek a feladatkörök taxatív felsorolására, így egyértelműen nem lehetett meghatározni a szolgabírák minden hatáskörét. E célt egyedül Doboka vármegye kívánta elérni. Több vármegye ezt külön hangsúlyozta azáltal, hogy a szolgabírák feladatait a szabályzaton túl a törvények, a szabályrendeletek, a törvényes szokás és a fennálló gyakorlat határozza meg. ${ }^{949}$ A szolgabíró továbbra is megmaradt a járás lakosságának „ügyes-bajos dolgainak ügyintézője". ${ }^{50}$ Ennek fényében kijelenthető, hogy a szolgabírákra különösen igaz volt Bars vármegye alábbi jellemzése: „A közigazgatási tisztviselőnek, szakja természeténél fogva nem annyira a hivatalszoba emberének, de mindenütt jelenlevö, mindent megfigyelöállami közegnek kell lennie, - 's a legfontosabb, fárasztóbb közigazgatási functiokat teljesiteni." 951

illem szabályok által a törvénykezési biróságokhoz vagy más hatóságokhoz nem utasittattak, vagy ezután utasittatni fognak.” - MNL BM K150 117.21068/1871. - Csongrád vármegye.

948 SZENTKIRÁlyi $1867,64-65$.

949 MNL BM K150 117. 21068/1871. - Csongrád vármegye; 22026/1871. - Felső-Fehér vármegye; 118. 32032/1871. - Gömör és Kis-Hont vármegye; 22187/1871. - Közép-Szolnok vármegye; 233. 28463/1873. - Moson vármegye.

950 MNL BM K150 118. 22499/1871. - Kővár vidék.

951 MNL BM K150 117.28287/1871. 



\section{A KÖZIGAZGATÁS ÉS \\ AZ IGAZSÁGSZOLGÁLTATÁS \\ ELVÁLASZTÁSA JÁRÁSI SZINTEN}

A közigazgatás és igazságszolgáltatás elválasztásának szükségessége az államszervezet alsó szintjein már a 19. század közepén felmerült a szolgabírák kapcsán Zsoldos Ignác művében, mert véleménye szerint olyan mértékben szaporodtak meg a szolgabírák közigazgatási teendői, hogy azokat már egy személy nem tudta teljeskörűen ellátni. Azt gondolta, hogy érdemes lenne a közigazgatási és az igazságszolgáltatási teendőket nem egy személy feladatkörébe utalni.952

A kiegyezést követően, 1868-ban azonban a jogbiztonság szempontjából nagy jelentőségü polgári perrendtartást fogadtak el, amelyben a polgári államszervezetet létrehozó törvények hiányában a rendi kori törvénykezési szervekre kellett építkeznie a jogalkotónak, így a szolgabíró és esküdttársa a megyékben elsőfokú bírói hatóságként funkcionáltak. ${ }^{953}$ Emellett e vármegyei tisztviselők kézbesítették a bírói határozatokat, részt vettek a végrehajtásban, okiratokat hitelesíthettek, öröklés esetén felvették a leltárt vagy a vásári bíráskodás esetén is eljárhattak. A rengeteg hozzájuk utalt hatáskör ellenére született meg az 1869. évi IV. tc., amely kimondta az igazságszolgáltatás és a közigazgatás teljes körű elválasztását. Ennek értelmében a szolgabírák elveszítették törvénykezési hatásköreiket.

\subsection{A hatalmi ágak elválasztásának megkérdőjelezése}

A két hatalmi ág elválasztása kapcsán a közéletben egyetértés mutatkozott, azonban éppen a járási szint kapcsán kérdőjelezték meg ennek célszerűségét. Az 1869:IV. tc. országgyűlési vitája során Tisza Kálmán, Dietrich Ignácz és Ghyczy Kálmán felszólalásaikban az ellenzék képviseletében azon álláspontjuknak adtak hangot, hogy az igazságszolgáltatás és a közigazgatás merev elválasztása nem lehet kívánatos az államszervezet minden szintjén, mert a gyakorlati élet követelményei ennek ellentmondanak. ${ }^{954}$ Tisza Kálmán emiatt az alapelv alóli kivétel lehetőségének megfogalmazását kérte a törvényben. Az ellenzéki képviselők a legalsóbb szinteken a csekély jelentőségű ügyekben nem kívánták a két hatalmi ágat elválasztani. Dietrich Ignác a rendőri ügyeket és a mezei kihágások ügyeit említette meg olyan jogvitákként, amelyeknél célszerủtlen azok elkülönítése. ${ }^{95}$ A törvénykezési és az adminisztratív ügyek alsószintű egy kézben összpontosítását a békebírói

\footnotetext{
952 Zsoldos 1866, 22.

953 Herczegh 1871, 62.

954 KN 1869. II. k. 374-377.

955 KN 1869. II. k. 376.
} 
rendszer meghonosításával tartották megvalósíthatónak. Horvát Boldizsár igazságügyminiszter elvetette azt, hogy a törvényben szerepeljen Tisza Kálmán javaslata, de szintén lehetségesnek tartotta, hogy a békebíróságok felállítására vonatkozó törvényjavaslatban megvalósulhasson a kezdeményezés. Azt viszont hangsúlyozta, hogy az Angliából vett minta magyarországi adoptálása igencsak problémás. ${ }^{956}$

Érdemes megjegyezni, hogy ebben a kérdésben nem volt teljes az egyetértés az ellenzéki táborban sem, ugyanis a kormánypárttal kritikus Magyar Ujság ebben a kérdésben nem értett egyet a szintén az ellentáborhoz tartozó országgyülési képviselőkkel. ${ }^{957}$ Abban nem mutatkozott eltérés, hogy az igazságszolgáltatási szervezet vármegyei alapjait fenntartani kívánták, viszont a napilap szerkesztősége ragaszkodott az államszervezet minden szintjén a két hatalmi ág elválasztásához. ${ }^{958}$

\subsection{Vármegyei reakciók a hatalmi ágak elválasztása kapcsán}

Az országgyülés mellett a vármegyei közéletben is felmerült, hogy járási szinten ne kerüljön elválasztásra a közigazgatás és az igazságszolgáltatás egymástól. Heves és Külső-Szolnok vármegye 1871. szeptember 18-án kelt, a Képviselóháznak címzett feliratában hasonló kívánalmának adott hangot a mezei rendőrségi ügyek kapcsán, mint az ellenzéki képviselők. ${ }^{959}$ A vármegye kiemelte, hogy a mezei rendőrségről szóló 1840:9. tc.-ben meghatározott ügyek a közigazgatást az igazságszolgáltatástól elválasztó 1869:IV. tc. értelmében az újonnan felállítandó járásbíróságokhoz kerülnek. A vármegye bizottmánya a „rossz emlékủ 1850-es évekre" utalva felhívta a Képviselőház figyelmét, hogy a lakosságot igen károsan érintené, ha ezekben az ügyekben a formálisabban müködő és helyhez kötött járásbíróságokhoz kellene fordulnia. Ehelyett azt kérték, hogy a szolgabírák továbbra is legalább békebírákként eljárhassanak ezekben az ügyekben, amely a vitás kérdések gyors, költséghatékonyabb és békés rendezését tenné lehetővé. Emellett azt javasolták, hogy az államszervezet e legalsóbb szintjén tekintsenek el a két hatalmi ág elválasztásától és tegyék lehetővé a szolgabírák bírói hatalommal való felruházását a mezei rendőrségi ügyekben. A vármegye feliratát az alapelv megkérdőjelezésével zárta. ${ }^{960}$

Jellemző a közszellemben gyökerező nagyfokú vármegyei önállóságra, hogy a vármegye a kívánsága teljesítéséig szabályrendeletileg úgy rendelkezett, hogy a már hatályban lévő törvény ellenére a szolgabírák legalább békebíróságként eljárhatnak ezekben az

KN 1869. II. k. 376.

Gergely-Veliky 1985, 112-114.

Magyar UjSÁG RöPIRATA 1868, VI- 20.

MNL BM K150 118. 491/LIX. 71.

MNL BM K150 118. 491/LIX. 71. Heves és Külső-Szolnok vármegye felirata: „A törvénykezésnek a közigazgatástól merev s a legalsóbb fokokig való különválasztása, úgy hogy ezen szabály alól semmi kivételnek se legyen helye, ha elméletben tán szépen hangzik is, a gyakorlati élet által, s mint a múltban már megtörtént hitünk szerint a jövöben is károsnak s az ezen rendszerrel való ujabb kisérlet is tarthatatlannak fog bizonyulni." 
ügyekben. A Képviselőház a feliratot elintézés végett a belügyminisztériumnak átadta. A minisztérium az iratok tanúsága szerint a tudomásul vételen kívül nem reagált a vármegyei indítványra. ${ }^{961} \mathrm{~A}$ későbbiekben még látható lesz, hogy a vármegye kérése nem volt irreális, ugyanis az országgyülésen folyamatosan napirenden volt a békebíróságokat szabályozó törvény elfogadása.

Csongrád vármegye ehhez nagyon hasonló kérésnek adott hangot a belügyminisztérium irányában az 1870:XLII. tc. végrehajtása alkalmával. Elsősorban azt kívánták, hogy a szolgabírák továbbra is eljárhassanak a mezei rendőrségi ügyekben. Ennek teljesíthetetlensége esetén viszont nem a békebírói rendszer létrehozatalát kívánták, hanem azt tartották szükségesnek, hogy az újonnan létrehozott magyar királyi járásbíróságok számára lehetőség nyíljon ezen ügyekben a soron kívüli, azonnali eljárásra. ${ }^{962}$ Bereg vármegye pedig feliratot intézett az igazságügyminisztériumhoz a célból, hogy terjesszenek elő olyan törvényjavaslatot, amelynek értelmében a szolgabírák továbbra is eljárhatnak a mezei rendörségi ügyekben. ${ }^{963}$

A szolgabírói tisztséget betöltő személyek is nehezen váltak meg a nagyobb megbecsültséggel járó és népszerűséget hozó igazságszolgáltatási teendőktől. Ezt tanúsítja egy Nyitra vármegyei eset 1872-ből, a két hatalmi ág elválasztásának végrehajtását megvalósító törvények hatályba lépésének első évéből, amikor hatásköri vita támadt a miavai járásbíró és a miavai szolgabíró között. A járásbíró ugyanis panasszal élt a szolgabíróval szemben, mivel a bepanaszolt a rendelkezése alatt álló csendőrség számára megparancsolta, hogy a járásbíró utasításainak a beleegyezése nélkül ne engedelmeskedjen. A járásbíró a büntető igazságszolgáltatást akadályozó visszaélés megszüntetését kérte.964

Bereg vármegye az ehhez hasonló problémás ügyek megelözése érdekében hatásköri szabályzatába foglalta, hogy ugyan a közbiztonsági személyzetet továbbra is csupán a szolgabírák utasíthatják, azonban a járásbíróságok rendkívüli esetekben szintén rendelkezhetnek közvetlenül a megyei rendőrséggel, amelyről azonnal értesíteni szükséges az érintett szolgabírát is. A törvényhatóság ilyen rendkívüli esetként azt határozta meg, amikor egy bűncselekményt közvetlenül a járásbíróságnál jelentenek be. Ezt a megoldást Bereg vármegye azzal indokolta, hogy a saját érdekük a megyei vagyon- és közbiztonság fenntartása. ${ }^{965}$

Csemegi Károly a törvény megalkotásának ideje alatt publikált tanulmányában mutatott rá, hogy a két hatalmi ág elkülönítésének legproblematikusabb része az igazságszolgáltatási és a közigazgatási ügyek közötti határ meghúzása. A jogszabály megszövegezője

\footnotetext{
961 MNL BM K150 118.32825/1871.

962 „[A]zon tekintettöl vezéreltetvén, hogy a mezö rendöri törvények minél gyorsabb alkalmazása által, egy feloll a vagyonbiztonság szilárditassék, más felöl a nép az idegen tulajdon tiszteletére szoktattatván, erkölcsi tekintetben nemesittessék: tiszteletteljesen megkérjük a' Nagyméltoságu Ministeriumot, méltóztassék oly intézkedést léptetni életbe, hogy a mezö rendöri ügyekben a közigazgatás szolgabirók járjanak el; vagy ha ezt elvi tekintetek tiltanák a járásbiróságok utasittassanak a mezö rendöri panaszoknak esetröl esetre soron kivül és azonnal elintézésére." - MNL BM K150 117.21068/1871.

963 MNL BM K150 118.22592/1871.

964 MNL BM K150 153.25192/1872.

965 MNL BM K150 118.22592/1871.
} 
kiemelte, hogy sem tételes törvény, sem a hazai jogtudomány nem foglalkozott ezzel a kérdéssel, ${ }^{966}$ így a gyakorlatnak kell az erre vonatkozó szabályokat kialakítania. ${ }^{967}$ Ennek fényében természetes, hogy a két hatalmi ág elkülönítése az országgyűlésben és a törvény végrehajtása során is vitákat generált. A közigazgatási és az igazságszolgáltatási hatáskörök tökéletes törvényi elkülönítésének lehetetlensége okán az ilyen esetekről való döntést az országgyủlés megfelelőbb fórum hiányában ideiglenesen a minisztertanácsra bízta a Deák Ferenc által felállítani javasolt állambíróság helyett. ${ }^{968}$

A vázolt problémára például szolgál az alábbi Hunyad vármegyei eset, amelyben a járás szolgabírája a keresztúri (Csernakeresztúr) községi bíróság előtt folyó adóssági perbe avatkozott be azáltal, hogy a községi bíróság elmarasztaló ítéletének végrehajtását felfüggesztette. A közigazgatási tisztviselő ezt azzal indokolta, hogy a községi bíróság megalakulása nem volt szabályszerủ. A pernyertes Holiczer Dániel emiatt a szolgabíróval szemben panaszt emelt a belügyminisztériumnál, ugyanis véleménye szerint erre nem volt annak jogosultsága. ${ }^{969}$

A belügyminisztérium az igazságügyminisztérium javaslatának megfelelően a közigazgatási tisztviselő határozatát megsemmisítette, mivel a szolgabíró közigazgatási közegként nem volt jogosult a bírósági szervezethez tartozó hatáskörben intézkedni. ${ }^{970} \mathrm{~A}$ minisztérium tehát az 1869:IV. tc. rendelkezéseinek megfelelően intézkedett a közigazgatási és az igazságszolgáltatási szervek hatásköri összeütközésében. Ebben az esetben megfigyelhető, hogy a szolgabíró a községek irányában korábban fennálló felügyeleti jogkörét gyakorolta, amelyet azonban a községi bíróságok tekintetében megszüntetett az 1869:IV. tc. Érdemes azonban megjegyezni, hogy ekkor még nem állt fel a rendes bírósági szervezet, amely tovább nehezítette a hatáskörök átláthatóságát.

\subsection{A törvénykezési feladatokat ellátó vármegyei segédszemélyzet „sorsa”}

Az igazságszolgáltatás és a közigazgatás elválasztása emellett nem várt problémákat is tartogatott, mivel Zala vármegye azzal a problémával szembesült a közigazgatás 1871. évi átszervezése során, hogy a vármegye a korábbi igazságszolgáltatási feladatokat ellátó segédszemélyzetét nem tudja tovább alkalmazni. Ennek megoldása érdekében

966 Csemegi 1869b, 288-291.

967 Csemegi 1869a, 100.

968 Nehrebeczky Sándor felszólalása - KN 1869. X. k. 140.; Szabó 2011, 175.; STipTA 2005b, 85-86.; PAPP 2017, 69-70.

969 MNL BM K150 152. 1872.II.2. 16793/1871.

970 „Azonban eltekintve ettöl, sem az állitólag közbejött kiegyenlités, sem a községi biróság alakitása körül netalán elkövetett szabálytalanság nem jogositották fel a szolgabirót mint közigazgatási tisztviselöt ez ügybe való beavatkozásra és a községi biróság eljárásának meg szüntetésére, mert az 1869:IV.t. cz. 1\$a szerint a közigazgatási hatóság a birói hatóság, tehát a községi biróság hatáskörébe se avatkozhatik, s mert a községi biróság ne talán sérelmes eljárása ellen a kelló orvoslatról a birósági szervezett (sic!) keretén belül maga a törvény gondoskodott s a sértett fél részére nem csak a törvény rendes utját, hanem a semmiségi panaszt is fennhagyta." - MNL BM K150 152. 1872.II.2. 6157/1872. 
a belügyminisztériumhoz fordult. ${ }^{971}$ A központi kormányszerv azonban e kérésnek nem tett eleget a következő indokolással: „mivel a törvényhatósági szegödöttek a fenálló szabályrendeletek értelmében, ugy az állam kincstár valamint a házi pénztár irányában, nyugdijra, végkielégitésre vagy bár mi néven nevezendö egyéb ellátásra igényt nem tarthatnak." ${ }^{\prime 72}$ A belügyminisztérium viszont értesítette az igazságügyminisztériumot a problémáról.

A koruk miatt a törvénykezésben már nem alkalmazható megyei szolgák támogatásának kieszközlésére újabb kísérletet tett a törvényhatóság válaszüzenetében. A belügyminisztérium azonban e kérést ismételten elutasította, mivel „ily czélra pénzalap rendelkezésre nem áll." Emellett pedig tájékoztatták a vármegyét, hogy a többi alkalmazott törvényszékek és járásbíróságok melletti alkalmazása érdekében a már kinevezett törvényszéki elnökökhöz forduljanak. ${ }^{973}$

\subsection{A békebírói tisztség koncepciója}

Felmerül a kérdés, hogy milyen feladatokat látott volna el az ellenzéki képviselők és Heves és Külső-Szolnok vármegye által követelt békebíró. A kiegyezést követően jelent meg a közbeszédben a békebírói intézmény angol minta alapján való meghonosításának elvárása Magyarországon, amellyel kapcsolatban kétségek is megfogalmazódtak, ugyanis hazánkban hiányzott az a jómódú birtokos réteg, amely vállalkozhatott volna a szigetországi példához hasonlóan a tisztség ingyenes ellátására. ${ }^{974} \mathrm{Az}$ új bírói szervezet létrehozását célzó törvényjavaslatban is szerepeltek a békebírák, mint az ügyekben elsőfokon eljáró törvénykezési szervek, azonban az erre vonatkozó részletes szabályokat a javaslat egy később létrehozandó törvényre kívánta bízni. ${ }^{975} \mathrm{~A}$ törvényjavaslat indokolása a közvélemény kívánságával és a pozitív külföldi példákkal indokolta a jogintézmény beemelését a törvényjavaslatba. ${ }^{976} \mathrm{Az}$ ígért törvényjavaslatot az igazságügyminisztérium a bíróságok rendezését biztosító javaslattal együtt terjesztette az országgyủlés elé. ${ }^{977} \mathrm{~A}$ békebírói jogintézményt övező vitákat jól szemlélteti, hogy a minisztertanácson elfogadott

\footnotetext{
971 „Mély tisztelettel fordulunk azért a nagyméltóságu m. k. belügyministeriumboz azon kérésünkkel, méltóztassék az itt elöadottak alapján a magas igazságügy ministerium figyelmét a körülményre irányozva pártoló közbenjárásával kieszközölni azt, hogy az érintett 's jövöre a szervezéssel a megyénél feleslegessé válandó foglárok és tiszti katonák a törvénykezés körüli szolgálattételnél alkalmazást nyerjenek és egyszersmind intézkedni kegyeskedjék, a magas belügyministerium az iránt, hogy azok közül a megye szolgálatában elaggottak 's további képtelenné váltak kiérdemelt elláttatásuk végett kielégitésben vagy nyugdijban részesittessenek." - MNL BM K150 117.21798/1871.

972 MNL BM K150 117.21798/1871.

973 MNL BM K150 117.31267/1871.

974 KeCSKemÉTHy $1867,53-58$.

975 Törvényjavaslat az első folyamodási biróságok rendezéséről. KI 1869. III. k. 267.

976 Indokok az első folyamodási biróságok szervezéséről szóló törvényjavaslathoz. KI 1869. III. k. 330. sz. irományhoz - 276 .

977 Törvényjavaslat a békebirákról. KI 1869. III. k. 310.
} 
alapelvektől jócskán eltért a benyújtott törvényjavaslat. ${ }^{978} \mathrm{Az}$ igazságügyminisztériumi előterjesztés szerint a békebírákat a törvényhatósági bizottság által titkos szavazás útján ajánlott, a feltételeknek megfelelő önkéntes jelentkezők közül az igazságügyminiszter ellenjegyzése mellett az uralkodó nevezte volna ki. Ennek a megoldásnak köszönhetően fenntartható maradt volna a törvénykezés területén lefektetett kinevezési elv akképpen, hogy a békebírói jogintézmény bevezetésével a törvényhatóságok is kaphattak volna jogosultságokat az igazságszolgáltatás terén. ${ }^{979} \mathrm{~A}$ tisztséget ingyenesen látták volna el a kinevezettek, akik a közigazgatási tisztviselők sorából is kikerülhettek volna. Hatáskörüket tágan határozták meg a minisztériumi előterjesztők. Az olyan ügyeket utalták a békebírákhoz, amelyeknek gyors, helyszíni elintézése szükséges. ${ }^{980}$ Egyeztető fórumként járhattak volna el közigazgatási és magánjogi jogvitákban, valamint büntető ügyekben kártalanítási igény esetén. A $30 \mathrm{Ft}$ pertárgyértékig terjedő magánjogi perekben, határjárási és sommás birtokperekben pedig ítélkeztek volna, amely ítéleteikkel szemben a rendes bírósági fórumokhoz lehetett volna fordulni. Emellett peren kívüli ügyekben, bünvádi és rendőri ügyekben is eljárhattak volna.

Az első folyamodású bíróságok rendezéséről szóló 1871:XXXI. tc. részletes képviselőházi vitája során a békebírák azonban kikerültek a javaslat szövegezéséből az első fokon eljáró bírói szervek közül, mivel Justh József kifogás tárgyává tette, hogy a jogalkotó a békebírákról szóló törvényre hivatkozott, amelynek megalkotásával még adós az országygyűlés. ${ }^{981} \mathrm{~A}$ békebírói tisztségről szóló törvényjavaslat plenáris megvitatására végül nem is került sor, mivel annak magyarországi átültetése kapcsán már a bizottsági vita során igen sok vitás kérdés merült fel. A jogintézmény bevezetését az országgyűlési képviselők és a törvényhatóságok is több alkalommal sürgették, míg végül az eredeti elképzelést átformálva a kisebb polgári peres ügyekben való eljárásról szóló 1877:XXII. tc. vezette be Magyarországon a békebíró tisztségét. ${ }^{92} \mathrm{Az}$ így megvalósult koncepció szerint azonban a békebírák a rendes bírósági szervezettől már nem függetlenül működtek, valamint ezen rendelkezés a közigazgatás és az igazságszolgáltatás konzekvens szétválasztását is relativizálta, mivel a törvény szerint a szolgabírák is betölthettek békebírói pozíciót.

\subsection{A két hatalmi ág elválasztásának lezárulta}

A fent ismertetett példákból látható, hogy a közigazgatás és az igazságszolgáltatás szorosan összefonódott az októberi diploma kiadása utáni időszakban is. Emiatt nyilvánvaló volt, hogy az 1869:IV. tc. hatalmi ágak elválasztására vonatkozó rendelkezéseit nem lehet végrehajtani az új igazságszolgáltatási szervezet felállításáig, így 1872. január 1-jén egyszerre

\footnotetext{
978 MÁTHÉ 1982, 136-139; BALOGH 2017, 47-48.

979 Indokok a békebirákról szóló törvényjavaslathoz. KI 1869. III. k. 327.

980 Indokok a békebirákról szóló törvényjavaslathoz. KI 1869. III. k. 327-328.

981 KN 1869. XVI. k. 97.

982 STipta 2010, 800.; MÁthé 2013, 94-98.
} 
kezdte meg müködését az új közigazgatási és törvénykezési szervezet, ${ }^{983}$ ezt követően érvényesülhetett a két hatalmi ág elválasztása. A legtöbb esetben a szükséges átmenet zökkenőmentesen ment végbe. Pozsony, Csongrád, Torna, Torontál, Veszprém, Arad, Ung és Bihar vármegye egyes szolgabírái azonban elmulasztották az elintézetlen iratok átadását a járásbíróságoknak. ${ }^{984}$ Ilyenkor az illetékes törvényszéki elnökök keresték meg az igazságügyminisztériumot, amely a belügyminisztériumot hívta fel arra, hogy utasítsa a vármegyék közönségét az elmaradt intézkedések pótlására. Ez alól kivételt képezett az egyik Torna vármegyei ügy, amikor Burger Sámuel kérelmezte a minisztériumnál az ügyiratok átküldését a tornai kir. járásbírósághoz az alsójárási „közigazgatási szolgabírótól”.985 Az ügyfél ezáltal sommás visszahelyezési perének gyorsabb elbírálását kívánta elérni. ${ }^{986}$ Ennek köszönhetően végül mindegyik törvényhatóság pótolta az ügyiratok szabályszerű eljuttatását az új törvénykezési szervek számára. Végül az általam vizsgált levéltári források alapján utolsóként 1872. november 6-án többszöri figyelmeztetést követően az Ung vármegyei mináji szolgabíróságot vezető Kovács Károly főszolgabíró is átadta az iratokat a nagykaproi járásbíróságnak, így lezárulhatott a két hatalmi ág elválasztása járási szinten az ügyiratok tekintetében. ${ }^{987} \mathrm{~A}$ két hatalmi ág fizikai elválasztása azonban még évekig váratott magára megfelelő épületállomány hiányában. ${ }^{988}$

\footnotetext{
983 BALOGH 2015, 23.

984 MNL BM K150 152. 8608/1872.; 29173/1872. - Csongrád vármegye; 8832/1872.; 18162/1872. Pozsony vármegye; 9048/1872.; 22648/1872. - Veszprém vármegye; 21995/1872. - Torna vármegye; 153. 15818/1872. - Arad vármegye; 24258/1872. - Bihar vármegye; 23836/1872. - Torontál vármegye; 9141/1872.; 24138/1872.; 39577/1872.; 42369/1872. - Ung vármegye.

985 Az iratokban külön kiemelték, hogy közigazgatási szolgabíróról van szó, mivel minden bizonnyal ezáltal akarták hangsúlyozni, hogy ezen ügyekben nem rendelkezik hatáskörrel. Ez amiatt is érdekes megoldás, mivel más közigazgatási iratokban nem lehet e kifejezéssel találkozni, mivel a szolgabíró megnevezést használja az 1870:XLII. tc.

986 MNL BM K150 152.7578/1872.; 9629/1872.

987 MNL BM K150 153.42369/1872.

988 Megyeri-PÁlffi 2015, 43.; Megyeri-PÁlffi 2017, 273-274.; Megyeri-PÁlffi 2018, 59.
} 



\section{A BELÜGYMINISZTÉRIUM BEFOLYÁSA}

A VÁRMEGYEI AUTONÓMIÁRA

„A törvény, törvényes rendeletek és felsöbbség iránti, hazánkban oly alapjaiban megingatott tiszteletnek $s$ ezzel a normalis politikai viszonyoknak helyreállitására, semmi tényezó sem hathat oly gyökeresen, mint az erélyesen kezelt közigazgatás. $S$ ha a chaosból és az emberek és viszonyok kényekedvétöl függö eddigi helyzetböl kibontakozni akarunk, ha a rendet, mely minden irányban okvetlenül szükség van, megteremteni akarjuk a célt biztositó eszközöket is használatba kell vennünk."

\subsection{A tervezetek beérkezésének és minisztériumi megerősítésének időpontjai}

A belügyminisztérium 1871. május 15-én adta ki rendeletét, amely alapján a vármegyéknek kellett felterjeszteni a közigazgatási szervezetükről szóló tervezeteiket a központi kormányzat számára. A magyar kormány 1872. január 1-jével kívánta hatályba léptetni az új igazságszolgáltatásra és közigazgatásra vonatkozó rendelkezéseket, így különösen fontos volt, hogy mikor érkeznek be a minisztériumhoz a felterjesztések.

Az első tervezetek már július 3-án megszülettek és július közepén iktatták őket a belügyminisztériumban. ${ }^{990}$ Arad vármegye azonban július 17 -én kérte a minisztériumot, hogy küldjék vissza munkálataikat, amelyet július 25 -én megtett a minisztériumi tanácsos. ${ }^{991}$ A törvényhatóság a kezdeti gyorsaságot követően nem siettette az újabb felterjesztések elkészítését, így augusztus 31-én felhívta a minisztérium, hogy pótolja ezt, amelynek 1871 szeptemberében eleget tett Arad vármegye.

A legtöbb vármegye felterjesztése csupán augusztusban és szeptemberben jutott el a belügyminisztériumhoz. ${ }^{992} \mathrm{Az}$ általam vizsgált törvényhatóságok közül Hont vármegye

989 MNL BM K150 117.21799/1871. - Bars vármegye.

990 MNL BM K150 117. 17731/1871. - Arad vármegye; 17803/1871. - Csanád vármegye; 17808/1871.

- Fejér vármegye.

991 MNL BM K150 117.22476/1871.

992 MNL BM K150 117. 20171/1871. - Aranyosszék; 21799/1871. - Bars vármegye; 21161/1871. - Békés vármegye; 21068/1871. - Csongrád vármegye; 21272/1871. - Doboka vármegye; 22026/1871. - FelsőFehér vármegye; 21800/1871. - Fogaras vidék; 22226/1871. - Krassó vármegye; 20826/1871. - Sáros vármegye; 21797/1871. - Szepes vármegye; 20991/1871. - Trencsén vármegye; 21798/1871. - Zala vármegye; 118. 23346/1871. - Alsó-Fehér vármegye; 22592/1871. - Bereg vármegye; 23816/1871. - Gömör és Kis-Hont vármegye; 22326/1871. - Komárom vármegye; 22499/1871. - Kővár vidék; 22691/1871. - Nógrád vármegye; 22336/1871. - Veszprém vármegye. 
késlekedett a legtovább, mivel csupán október 26-án fogadta el a végleges munkálatait és ezek november 3-án érkeztek be a központi kormányzathoz. ${ }^{993}$

Az első tervezetekre a belügyminisztériumi válaszok jellemzően két hét és egy hónap közötti időtartam alatt készültek el. ${ }^{994}$ Igaz, ennek kapcsán a minisztériumi munka rendszertelen képet mutat, mivel a felterjesztését a legkorábban megküldő Fejér vármegye részére három hónapot követően csupán október 13 -án kelt a leirat. ${ }^{995} \mathrm{Az}$ első munkálatait legkésőbb megküldő Hont vármegye számára viszont mindösszesen öt nap alatt elkészítette a tanácsos iránymutatását. ${ }^{996}$ Néhány kirívó példától eltekintve a belügyminisztérium a beérkezési sorrendet tartva igyekezett feldolgozni a törvényhatósági felterjesztéseket.

A belügyminisztériumi tanácsosok a módosított tervezetek esetében már jóval rövidebb határidőkkel dolgoztak. Érezhetően sürgette őket a kormányzat által kitűzött határidő, bár ez az ügybuzgalom a törvényhatóságok részéről kevéssé mutatkozott. Az ezekben az ügyekben eljáró hivatalnokok jellemzően egy héten belül reagáltak a beérkezett munkálatokra, ${ }^{997}$ decemberre fordulva pedig már egy-két napon belül igyekeztek útmutatást nyújtani a vármegyéknek. ${ }^{998}$ Ennek ellenére Hont vármegye a közigazgatási szervezetéről szóló tervezetét csupán december közepén tudta véglegesíteni. ${ }^{999}$ Nógrád vármegyében szintén elhúzódott a közigazgatási szervezet kialakításának rögzítése, mivel a vármegye harmadik előterjesztése december 24-én érkezett be, így a belügyminisztérium válasza december 26-án készülhetett csak el. ${ }^{1000}$ Felső-Fehér vármegye esetében, bár kevésbé lényeges kérdésben (előfogati díjak megállapítása), „kicsúsztak” a határidőből, mivel csak december 30-án erősítették meg azokat a belügyminisztériumi tanácsosok. ${ }^{1001}$

$\mathrm{Az}$ ismertetett adatok igazolják azt, hogy a belügyminisztériumi tanácsosok munkájuk felgyorsításával törekedtek arra, hogy a magyar kormányzat által kitűzött 1872. január 1-jével az újonnan felállítandó közigazgatási szervezet megkezdhesse működését.

993 MNL BM K150 118. 28726/1871.

994 MNL BM K150 117.32702/1871. - Arad vármegye; 20171/1871. - Aranyosszék; 21799/1871. - Bars vármegye; 21068/1871. - Csongrád vármegye; 21272/1871. - Doboka vármegye; 34430/1871. - FelsőFehér vármegye; 22026/1871. - Felső-Fehér vármegye; 21800/1871. - Fogaras vidék; 22226/1871. - Krassó vármegye; 20826/1871. - Sáros vármegye; 21797/1871. - Szepes vármegye; 20991/1871. Trencsén vármegye; 21798/1871. - Zala vármegye; 118. 22592/1871. - Bereg vármegye; 23816/1871. - Gömör és Kis-Hont vármegye; 22326/1871. - Komárom vármegye; 22499/1871. - Kővár vidék; 25309/1871. - Küküllő vármegye; 22336/1871. - Veszprém vármegye.

MNL BM K150 118. 28726/1871.

MNL BM K150 117.27282/1871. - Csongrád vármegye; 27291/1871; 27079/1871. - Fejér vármegye; 29328/1871. - Fogaras vidék; 31267/1871. - Zala vármegye; 118. 30266/1871. - Kővár vidék; 31404/1871. - Küküllő vármegye; 28989/1871. - Nógrád vármegye; 30172/1871. - Veszprém vármegye.

998 MNL BM K150 117.32702/1871. - Arad vármegye; 32776/1871. - Csanád vármegye; 34430/1871. - Felsö-Fehér vármegye; 32636/1871. - Krassó vármegye; 118. 31986/1871.; 33141/1871. - Hont vármegye; 34064/1871. - Komárom vármegye.

999 MNL BM K150 118.33141/1871.

1000 MNL BM K150 118.34064/1871.

1001 MNL BM K150 117.34430/1871. 


\subsection{A belügyminisztérium megerősítési jogának tartalma}

A korábbi fejezetekben már ismertetett módon az 1870:XLII. tc. értelmében a törvényhatóságok kötelesek voltak a közigazgatási szervezetre vonatkozó tervezeteiket felterjeszteni a belügyminisztérium számára. A vármegyék által a központi kormányzathoz eljuttatott tervezeteket a legtöbb esetben csupán egy alkalommal kellett helyesbítés céljából visszaküldeni a törvényhatóságok számára a megerősítést megelőzően. ${ }^{1002}$ Négy vármegye esetében viszont erre két alkalommal is szükség volt. ${ }^{1003}$ Ennek oka, hogy Hont vármegye mindenképpen ragaszkodott az általa kiépített önkormányzati igaz-

gatási szervezethez, így a belügyminisztérium igyekezett elérni, hogy végül elfogadja az általa helyesnek tartott álláspontot. Csanád vármegye esetében az előfogati díjak megállapítása ütközött nehézségekbe és a már említett szolgabíróval kapcsolatos terminológiához kötődő tollhiba miatt volt szükség a háromszori levélváltásra a „kompromisszum" megszületéséhez. Arad vármegye viszont egy alkalommal még a vizsgálat előtt kérte a tervezetének visszaküldését, mert a már a járások kapcsán vázolt változások miatt módosítani kívánt azon, így csupán egy alkalommal hívta fel érdemi korrekcióra a belügyminisztérium. Komárom vármegye pedig a fö- és alszolgabírói tisztségek elvetését nem kívánta elfogadni, valamint a járási közgyámi hivatal mellőzését. A vizsgáltak közül három törvényhatóságról, Aranyosszékről, Szepes és Zaránd vármegyéről mondható el, hogy átalakításra való felhívás nélkül már az első felterjesztését jóváhagyták a belügyminisztériumi tanácsosok. ${ }^{1004}$ Ezek az adatok igazolják, hogy a törvényhozás részéről helyes megoldás volt a belügyminisztériumi megerősítés bevezetése, ugyanis alig érkezett be a törvényhatóságok részéről teljes mértékben megfelelően elkészített tervezet, így szükség volt a minisztériumi utómunkálatok elvégzésére, hogy a törvény céljaival egyező közigazgatási szervezetek jöjjenek létre.

A köztörvényhatósági törvény 91 . \$-a tehát a minisztériumot a tervezetek „megerősítésére" hatalmazta fel. Ennek kapcsán elvi kérdésként merül fel, hogy az érintettek miképpen értelmezhették ezt a „megerősítési” jogot a jogszabály alkalmazása során. A fejezet további részében a belügyminisztérium és a törvényhatóságok között a munkálatok során kirajzolódó kapcsolatot mutatom be a közigazgatási tervezetek segítségével.

1002 MNL BM K150 117. 21799/1871.; 28287/1871. - Bars vármegye; 21161/1871.; 31913/1871. Békés vármegye; 21068/1871.; 27282/1871. - Csongrád vármegye; 17808/1871.; 27079/1871. - Fejér vármegye; 22026/1871.; 34430/1871. - Felsö-Fehér vármegye; 21800/1871.; 29328/1871. - Fogaras vidék; 22226/1871.; 32636/1871. - Krassó vármegye; 20826/1871.; 27062/1871. - Sáros vármegye; 20991/1871.; 28525/1871. - Trencsén vármegye; 21798/1871.; 31267/1871. - Zala vármegye; 118. 23346/1871.; 31726/1871. - Alsó-Fehér vármegye; 22592/1871.; 27001/1871. - Bereg vármegye; 23816/1871.; 32051/1871. - Gömör és Kis-Hont vármegye; 22499/1871.; 30266/1871. - Kővár vidék; 25309/1871.; 31404/1871. - Küküllő vármegye; 22691/1871.; 28989/1871. - Nógrád vármegye; 22336/1871.; 30172/1871. - Veszprém vármegye.

1003 MNL BM K150 117. 17731/1871.; 17731Sz/1871.; 32702/1871. - Arad vármegye; 17803/1871.; 27291/1871.; 32776/1871. - Csanád vármegye; 118. 28726/1871.; 31986/1871.; 33141/1871. - Hont vármegye; 22326/1871.; 30274/1871.; 34064/1871. - Komárom vármegye.

${ }^{1004}$ MNL BM K150 117.20171/1871.; 21797/1871.; 118. 25636/1871. 
A vármegyei tervezetekben kidolgozott megoldások legnagyobb részét a minisztériumi tanácsosok a törvény szellemével és szövegével egyezőnek találták, így megerősítették azokat. A kutatás homlokterében azonban nyilvánvalóan nem ezek az esetek állnak, mivel a „megerősítés” tartalma azokból az ügyekből mutatható ki, amikor a törvényhatóságok és a minisztérium eltérő álláspontra helyezkedett egy kérdésben. Munkám során a tervezeteknek csak a járásokkal, járási tisztviselőkkel foglalkozó részeit elemeztem.

A törvényhatóságok esetében a belügyminisztérium a közigazgatási szervezet egységesítését legtöbbször a törvény kereteire hivatkozva végezte. A vármegyék, a székek és a vidékek ugyanis tervezeteikben több alkalommal a törvény rendelkezéseitől eltérő módon alakították alsó középszintü közigazgatási szervezetüket, ahogy az az előző fejezetekben látható volt. Ennek megfelelően a minisztérium Bars és Hont vármegyét felhívta az aljárások kiiktatására, mivel ez ütközött a törvény rendelkezéseivel. ${ }^{1005}$ Bereg vármegye viszont az első tervezetre adott válaszában a főhatóság nem szerepeltette az aljárások mellőzését, mivel a teljes járási beosztás átalakítását kérték ${ }^{1006}$ így ennek megtagadásakor a belügyminisztérium a vármegye jóváhagyása nélkül kijelentette, hogy egységesen a járási elnevezést kell alkalmazniuk a szolgabírói illetékességi területekre. ${ }^{1007}$ A fó-, alszolgabírák vagy esküdtek járási szervezetben való szerepeltetése kapcsán szintén azt hangsúlyozták, hogy ez az 1870:XLII. tc. rendelkezéseivel ellentétben áll. ${ }^{1008}$ Hont vármegye tervezeteinek vizsgálatakor az esküdtek elhagyására való felszólításánál viszont inkább csak utalt a törvény szellemére a választ elkészítő tanácsos. ${ }^{1009}$ A szolgabírósegédi elnevezés alkalmazását viszont nem a törvény rendelkezéseivel indokolta a minisztérium, hanem csak kategorikusan kijelentette, hogy ez az elnevezés használandó. ${ }^{1010}$

A szolgabírói tisztségnek a törvény rendelkezéseihez való igazítása során érdekes kérdésként merült fel, hogy miképpen értelmezendő a köztörvényhatósági törvény 62 . \$-a, amelynek alapján „az egyes tisztviselők hagyományos nevei megtarthatók." Sáros vármegye a föszolgabírói, Hont vármegye pedig az esküdti cím kapcsán hivatkozott erre. ${ }^{1011}$ A belügyminisztérium viszont mindkét esetben visszautasította ezt, annak ellenére is, hogy a törvény rendelkezéseire alapították a törvényhatóságok szervezeti megoldásaikat. Nagy-kikinda kerület viszont eredményesen hivatkozott erre a tanácsnoki tisztség megőrzése érdekében, amelyet így nem is kifogásoltak a tanácsosok. ${ }^{1012} \mathrm{E}$ szakasz mikénti értelmezésére a minisztérium tehát nem adott pontos iránymutatást.

Az egységes közigazgatási szervezet átalakításának szükségességét a törvény rendelkezéseihez való igazodással indokoló, a szolgabírósegédek választhatóságára vonatkozó

\footnotetext{
${ }^{1005}$ MNL BM K150 117.21799/1871.; 118. 28726/1871.

1006 MNL BM K150 118. 22592/1871.

1007 MNL BM K150 118. 27001/1871.

${ }^{1008}$ MNL BM K150 117. 21799/1871. - Bars vármegye; 21161/1871. - Békés vármegye; 27291/1871.

- Csanád vármegye; 118. 23816/1871. - Gömör és Kis-Hont vármegye.

1009 MNL BM K150 118. 28726/1871.

1010 MNL BM K150 117. 17731Sz/1871. - Arad vármegye; 118. 22336/1871. - Veszprém vármegye.

1011 MNL BM K150 117.27062/1871.; 118. 28726/1871.

${ }^{1012}$ MNL BM K150 117.24696/1871
} 
belügyminisztériumi ajánlásokat az általam vizsgált törvényhatóságok közül egyedül Hont vármegye nem fogadta el. Ebben az esetben a belügyminiszter utasítására a belügyminiszteri tanácsos végül jóváhagyta a vármegye megoldását. ${ }^{1013}$ E példákból kitűnik, hogy a belügyminisztérium a törvény rendelkezéseire való hivatkozással általában eredményesen szólította fel a vármegyéket az önkormányzati igazgatási szervezeteik átalakítására, azonban, ha valamely törvényhatóság nem tett eleget ennek, akkor nem mindig érvényesítették akaratukat a vármegyei autonómiával szemben.

A törvényhatósági járások és fizetések megállapítása kapcsán viszont a belügyminisztérium ettől eltérő megoldásokat alkalmazott. A törvény nem szabályozta azt, hogy a vármegyéknek milyen lakosságszámú és területű járásokat kell kialakítaniuk, így a küldöttségek, a közgyűlések és a belügyminisztérium közös munkálatai határozták meg azok nagyságát. A köztörvényhatósági törvény csupán az országos választókerületek figyelembevételével nyújtott támpontot. A fizetések meghatározása törvényi rendelkezés hiányában szintén a vármegyék autonómiájába tartozott. Ennek köszönhetően a belügyminisztérium nem hivatkozhatott a törvény rendelkezéseire ezekben az esetekben, ha valamilyen módosítást kívánt.

A belügyminisztérium a járási beosztás ügyében több vármegyét is felszólított a járások számának csökkentésére. ${ }^{1014}$ Ezt jellemzően a törvényhatóság területén található járásbíróságok és országos választókerületek számára hivatkozva kérte a belügyi kormányzat. ${ }^{1015} \mathrm{Az}$ országos választókerületekkel való indoklás esetében sem említették meg azonban a tanácsosok, hogy ezt a törvényi kötelezettség miatt kívánnák meg. Bereg vármegye számára a válasz készítője még azt is megjegyezte, hogy a járások egyenlőtlen lakosságszáma miatt is kívánatosnak tartja az átszervezést. ${ }^{1016} \mathrm{~A}$ minisztérium csupán Alsó-Fehér vármegye számára javasolta konkrétan, hogy milyen mértékben kellene csökkenteniük a járásaik számát. (13-ról 10 járás) ${ }^{1017}$ Közülük Csongrád és Arad vármegye elfogadva a belügyminiszteri kérést alakította át területi felosztását. ${ }^{1018}$ Bars, Krassó, Sáros, Alsó-Fehér, Bereg, Hont vármegye ezzel ellentétben ragaszkodott az általuk megalkotott tervezethez. ${ }^{1019}$

1013 MNL BM K150 118. 33141/1871.

${ }^{1014}$ MNL BM K150 117. 117731Sz/1871. - Arad vármegye; 21799/1871. - Bars vármegye; 21068/1871.

- Csongrád vármegye; 118. 23346/1871. - Alsó-Fehér vármegye; 22592/1871. - Bereg vármegye; 28726/1871. - Hont vármegye.

1015 „A megye területe, mely 6 választó kerületre oszlik és 7 járás birósággal lesz ellátva, 12 szolgabirói járásra osztatott fel.” MNL BM K150 117. 17731Sz/1871. - Arad vármegye; „[A] megye területe, mely csak 4 választó kerületre oszlik s öt járásbirósággal lesz ellátva öt járás, illetöleg két járásnál a törvény világos rendelete ellenére javaslatba kapott szakaszok hozzá számitásával hét járásra osztatott fel." - MNL BM K150 118. 22592/1871. - Bereg vármegye; 117.21068/1871. - Csongrád vármegye; 21799/1871. Bars vármegye.

1016 MNL BM K150 118. 22592/1871.

1017 „[E]miatt elkerülhetetlenül szükségesnek tartom a szolgabirói járásoknak a küldöttség által javaslatba hozott tiz járásra leendő apasztását, ebböl kifolyólag a járási tisztviselók létszámának kevesbitését." - MNL BM K150 118. 23346/1871.

1018 MNL BM K150 117.27282/1871.; 32702/1871.

1019 MNL BM K150 117. 28287/1871.; 22226/1871.; 20826/1871. 118. 31726/1871.; 27001/1871.; $31986 / 1871$. 
Arad, Bars, Békés, Csongrád, Bereg, valamint Gömör és Kis-Hont vármegyéktől a belügyminisztérium a tisztviselők fizetésének leszorítását kívánta. ${ }^{1020}$ Arad, Csongrád, valamint Gömör és Kis-Hont ennek megfelelően csökkentette a javadalmakat, ${ }^{1021}$ Bars, Békés és Bereg vármegye viszont fenntartotta az eredetileg megállapítottakat. ${ }^{1022}$

Látható, hogy a belügyminisztérium tisztségviselőinek tekintettel kellett lennie a törvényhatóságokat megillető, törvényben garantált autonómiára. Ennek megfelelően a járások számának csökkentése és a fizetések leszállítása esetén, mivel törvényi kötelezettség hiányában kérte a közigazgatási szervezet átalakítását, minden alkalommal rögzítette a minisztériumi rendelkezést elkészítő, hogy „nem szándékom a megye önkormányzati hatáskörét megszorítani.” ${ }^{1023}$ Kényszerítő eszköz hiányában arra való figyelmeztetéssel igyekezett a belügyminisztérium a kormányzati felszólítások teljesítésére szorítani a vármegyéket, hogy az 1870. évi XLII. törvény értelmében a jövőben nem az állami segélyezés biztosítja a közigazgatási költségeiket, hanem az adott helyi önkormányzat házi pénztárának kell azt finanszíroznia az állam által átengedett adókból, és az ezt a keretet meghaladó kiadástöbbletet pedig a törvényhatóságoknak a lakosságuktól beszedendő pénzösszegből szükséges fedezniük. E vármegyék tervezeteiből kitűnik, hogy a törvényhatóságok a számukra előirányzott summából valóban képtelenek lettek volna finanszírozni a közigazgatási szervezetük fenntartását. Ez azonban nem meglepő, mert a törvényhatóságok többsége szintén hasonló helyzetben volt. A figyelmeztetett vármegyék közül egyedül Békés nem küzdött ezzel a problémával, így a tanácsosok a vármegye közönsége irányában nem éltek az említett formulával. ${ }^{1024}$

Azonban nem minden törvényhatóság tett eleget a belügyminisztérium felszólításának. A tanácsosok kifejezett törvényellenesség hiányában megerősítették e tervezeteket is, azonban ismételten ugyanazon módon figyelmeztették a vármegyéket, hogy a kiadástöbbletet újabb adókivetés által kötelesek fedezni, mivel a kormányzat erre vonatkozóan nem nyújthat segítséget. ${ }^{1025}$ Alsó-Fehér és Hont vármegyében hiába állt fenn ugyanez a helyzet, az esetükben elmaradt az állandó formula. ${ }^{1026}$

A felsorolt példákból kitűnik, hogy nem minden finanszírozási problémákkal küszködő törvényhatóságot szólított fel a belügyminisztérium a közigazgatási szervezetének átalakítására. Nehéz magyarázatot találni arra, hogy az adminisztrációját önállóan fedezni képtelen Aranyosszék, Fogaras vidék, Felső-Fehér vármegye, Doboka vármegye vagy Kővár vidék esetében a belügyminisztérium mi okból hagyta jóvá a tervezeteket

\footnotetext{
${ }^{1020}$ MNL BM K150 117. 17731Sz/1871.; 21799/1871.;21161/1871.;21068/1871.; 118. 27001/1871.; $23816 / 1871$.

1021 MNL BM K150 117.32702/1871.; 27282/1871.; 118. 32051/1871.

1022 MNL BM K150 117. 28287/1871.; 31913/1871.; 118. 27001/1871.

${ }^{1023}$ MNL BM K150 117. 17731Sz/1871. - Arad vármegye; 21799/1871. - Bars vármegye; 21161/1871. Békés vármegye; 118. 23346/1871. - Alsó-Fehér vármegye; 22592/1871. - Bereg vármegye; 28726/1871. - Hont vármegye.

1024 MNL BM K150 117.21161/1871.

1025 MNL BM K150 117. 28287/1871. - Bars vármegye; 31913/1871. - Békés vármegye; 118. 27001/1871.

- Bereg vármegye.

1026 MNL BM K150 118.31726/1871.; 31986/1871.
} 
komoly korrekciós felhívások nélkül. ${ }^{1027}$ Feltételezhető, hogy a kormányzat is tisztában volt azzal, hogy az erdélyi rendezetlen közigazgatási viszonyok hosszabb ideig már nem tarthatók, így ezek munkálatainak megerősítésére kisebb hangsúlyt fektethettek. Nem kizárt, hogy már ekkor körvonalazódott a területi rendezés terve, amelynek első változata 1873-ra el is készült.

A napidíjak és az előfogati díjak megállapításához a köztörvényhatósági törvény szintén nem nyújtott útmutatást. Ebből az következne, hogy a vármegyék szabadon határozhatták meg ezek mértékét. A minisztériumi tanácsosok azonban a tervezetek e részét is igyekeztek kívánságaiknak megfelelően korrigálni. Így Fejér és Bars vármegyét felhívta a minisztérium a napidijak mérséklésére, ${ }^{1028}$ amelynek a két törvényhatóság eleget is tett. ${ }^{1029}$ Gömör és Kis-Hont vármegye a miniszteri tanácsos kérésének megfelelően szintén csökkentette a napidíjakat, viszont ezt az alispán esetében nem tartották elegendőnek a megerősítés alkalmával, így a vármegye megkérdezése nélkül $6 \mathrm{Ft}$-ról 5-re változtatták. ${ }^{1030}$ Csanád vármegye esetében a kormányzati szerv a fuvarköltség módosítását kérte, ${ }^{1031}$ amelyet viszont nem fogadtak el, így a minisztérium állapította meg ennek mértékét. Erről „a megye közönségét maga miheztartás végett" értesítették. ${ }^{1032}$ Hont vármegye esetében pedig felszólítás nélkül önhatalmúan módosították a belügyminisztériumi tanácsosok a napidijakat és az előfogati díjakat. ${ }^{1033}$ Békés vármegye a belügyminisztérium kérése ellenére nem változtatott a napidíjakon, azonban a minisztérium ezt végül elfogadta. ${ }^{1034}$ Ez érthető volt, hiszen Békés vármegye azon kevés törvényhatóság közé tartozott, amely képes volt a számára átengedett adóbevételből finanszírozni saját közigazgatási kiadásaikat.

A napidijakra és előfogati díjakra vonatkozó minisztériumi megerősítések tehát nem törekedtek a kompromisszum megteremtésére, hanem bizonyos esetekben a központi kormányzat akár a törvényhatósági autonómia megsértésével is keresztül vitte akaratát.

A belügyminisztérium munkálatait vizsgálva merőben eltérő kép vázolható fel tehát a „megerősítési” jogról, amelyek közös jellemzőit egybegyűjtve háromféle minta mutatható ki. A minisztérium ugyanis a törvényi rendelkezésekre hivatkozva a törvényhatósági szervezetek egységesítése érdekében általában eredményesen lépett fel a vármegyékkel szemben. Hont vármegye ellenállása esetében nem korlátozta a törvényhatóság önkormányzati jogait, hanem a miniszteri utasítás következtében meghajolt akarata előtt. Egyértelmű törvényi rendelkezések hiányában a járások méretét és a tisztviselői fizetések mértékét meghatározó tervezetek kapcsán viszont csupán a lakosság adóterheinek növekedésével „riogatva”

\footnotetext{
1027 MNL BM K150 117. 20171/1871.; 21800/1871.; 29328/1871.; 22026/1871.; 34430/1871.; 21272/1871.; 118. 22499/1871.; 30266/1871.

1028 MNL BM K150 117. 17808/1871.; 21799/1871.

1029 A napidijakat „jelentékenyen alább szállitottuk”, bár „azok mérvét túlságosaknak épen nem tarthatjuk.” MNL BM K150 117.27079/1871. - Fejér vármegye; 28287/1871. - Bars vármegye

1030 MNL BM K150 118. 23816/1871.; 32051/1871.

${ }^{1031}$ MNL BM K150 117.27291/1871.

1032 MNL BM K150 117.32776/1871.

1033 "[A] tisztviselök napidijairól be mutatott tervezetet azonban úgy a házi pénztár mint a magán felek érdekének megóvása tekintetéböl meg nem erösithetvén a napidijakat következö mérvben állapitom meg." - MNL BM K150 118. 31986/1871.

${ }^{1034}$ MNL BM K150 117.21161/1871.; 31913/1871.
} 
igyekezett álláspontját érvényre juttatni. Az ellenkezőkkel szemben fel sem merülhetett meggyöződésének keresztülvitele. E tények figyelembevételével igazán különös, hogy a jogszabályi alap hiánya ellenére a felfogásukkal nem egyezően megszabott napidíjak és előfogati díjak módosítására felszólította a belügyminisztérium a törvényhatóságokat, sőt szükség esetén a vármegyei közigazgatási autonómiába beavatkozva megváltoztatta azok mértékét. A belügyminisztérium tevékenységének sokszínűsége miatt így nem lehet egyértelműen meghatározni a „megerősítés” tartalmát.

A törvény szövege alapján a változásokat elemző szerző, Sarlós Béla, a tervezetek minisztériumi megerősítése kapcsán kifejtette, hogy ezzel korlátozták a vármegye autonómiáját és így a központi közigazgatás befolyásának kiterjesztését ismerte fel benne. ${ }^{1035} \mathrm{~A}$ levéltári források elemzése rámutatott arra, hogy a minisztérium ezt a jogosultságát igen mértékletesen gyakorolta. A legtöbb esetben nagy figyelmet fordítottak arra, hogy a törvényhatóságokat önkormányzati jogaik gyakorlásában szükségtelenül ne akadályozzák. A megerősítés nem biztosított ellenőrzési jogkört a minisztérium számára. A minisztérium által a tervezetekre visszaküldött válaszlevelek inkább tanácsadásokként értékelhetők, amelyeket újra meg kellett tárgyalnia a vármegyei közgyủléseknek, azonban a minisztérium nem kényszerítette rájuk álláspontját. Ha a belügyi kormányzat és a törvényhatóság álláspontja között nem jött létre véleményazonosság, akkor kevés számú és kevésbé jelentős esetek kivételével érvényesülhetett a vármegyék elképzelése. Ilyen esetek kizárólag a napidíjak és az előfogati díjak megállapítása körül fordultak elő. Az viszont nem zárható ki, hogy a kötelezö megerösítés miatt a törvényhatóságok bizonyos fokú öncenzúrát gyakoroltak. Megállapítható így, hogy a megerősítés ezen formája inkább tekinthető tájékoztatási kötelezettségnek, mint autonómia korlátozásnak, amelyet igen csak indokolttá tesz azon körülmény, hogy a vármegyei hatóságok látták el az állami közigazgatás közvetítését. A belügyminisztériumi munkálatoknak köszönhetően a törvényhatóságok járási szervezete nagy lépést tett annak irányába, hogy a korábbi partikuláris, rendi közigazgatási egységből a polgári kor követelményeinek megfelelő, egységes közigazgatási szervezetté alakuljon.

\subsection{A vármegyék közigazgatási költségeinek fedezési módja}

Az 1870:XLII. tc. 2. §-a valódi önkormányzattal rendelkező törvényhatóságokat kívánt létrehozni, így a rendi hagyományokat felelevenítve a törvényhatóságok hatáskörébe vonta az önkormányzat és a közigazgatás költségeinek megállapítását és azok fedezetéről való gondoskodást. Mivel a kiegyezést követően fenntartották a területi önkormányzatok állami segélyezését, ${ }^{1036}$ így ez az átalakítás jelentős változást hozott a vármegyei institúció működésében. Ennek megfelelően, ahogyan az az előző fejezetben látható volt, a belügyminisztérium erre való figyelmeztetéssel igyekezett a törvényhatóságokat bizonyos esetekben tervezeteik módosítására rászorítani.

1035 SARLÓs 1976, 77.

1036 KMETy 1905, 173.; LADIK 1932, 53. 
Az országgyűlés az 1870:XLII. tc. 90. §-ban gondoskodott arról, hogy ez az állampolgárok adóterheinek jelentős növekedése nélkül valósulhasson meg. A törvény e szakasza ugyanis úgy rendelkezett, hogy a pénzügyminiszternek és a belügyminiszternek olyan törvényjavaslat kidolgozásáról kell intézkednie, amely a föld-, ház-, jövedelem- és személyes kereseti adót az adott évben az állam által kiszolgáltatott közigazgatási költségeknek megfelelő mértékben csökkenti. A törvényhatóságok az „állami közigazgatás” feladataiban is részt vállaltak, így ez a megoldás indokolt volt. ${ }^{1037} \mathrm{~A} 11$. $\$$ alapján a háziadót az erről szóló újabb törvény elfogadásáig a magyar királyi adóhivatalok szedték be az államadóval együtt, amelyet havonta előzetesen szolgáltattak ki a törvényhatóságoknak. ${ }^{1038}$

A rendelkezésnek megfelelően a pénzügyminisztérium 1871. június 4-én 2653. számú körrendeletével táblázatos formában megküldte a vármegyék számára annak a pénzösszegnek a mértékét, amelyet a törvényhatóságok a tervek szerint felhasználhattak volna közigazgatási feladataik ellátásához. ${ }^{1039}$ Ezt az 1870. évi költségvetésben szereplő közigazgatási költségek és az ugyanazon évre kivetett adóösszegek figyelembevételével számították ki. A közigazgatási költségekhez számították a köztörvényhatósági törvény 8. §-a alapján a törvényhatóságok hatáskörébe kerülő árva- és gyámhatósági teendők ellááására szolgáló kiadásokat is. E számítás alapján a megyék, kerületek, vidékek és székek adminisztrációjuk fenntartására évi egyenes adójuk 7,76 \%-ának használhatták fel. A rendelet kiadásakor már érzékelte a pénzügyminisztérium, hogy ez az összeg számos törvényhatóság esetében jelentősen eltér a korábban az államkincstárból kiszolgáltatottól, így második kalkulációként elkészítette a személyes kereseti adók arányos leszállításával (56,80\%) létrejövő költségkeretet is.

Az 1870:XLII. tc. végrehajtása során az összes törvényhatóság és a belügyminisztérium is a pénzügyminiszter által kiadott rendeletet és az egyenes adók 7,76\%-a alapján megállapított pénzösszegeket vették alapul. ${ }^{1040}$ Doboka vármegye és Kővár vidék azonban a számára kedvezőbb személyes kereseti adóból kalkulált finanszírozási fedezetre kívánt támaszkodni. ${ }^{1041} \mathrm{Az}$ általam vizsgált vármegyék esetében csupán Fejér, Csanád és Békés vármegyében volt elegendő az 1870. évi közigazgatási költségekre a pénzügyminisztérium által előirányzott összeg, azonban közülük is Békés vármegye a jövőbeli szükségleteit úgy határozta meg, hogy túlterjeszkedett a megadott kereten. Ebből látható, hogy a feldolgozott törvényhatóságok közül csupán két vármegye építette ki olyan módon közigazgatási szervezetét, hogy újabb adókivetés nélkül a számára biztosított pénzösszegből megfelelően tudott volna gazdálkodni. Aranyosszék, Doboka, Zala, Alsó-Fehér és Veszprém vármegye,

\footnotetext{
1037 STIPTA 1995b, 157.

1038 MNL BM K150 118. 22336/1871.

1039 24. A m. kir. pénzügyminister körrendelete.

1040 MNL BM K150 117.32702/1871. - Arad vármegye; 20171/1871. - Aranyosszék; 21799/1871. - Bars vármegye; 21161/1871. - Békés vármegye; 17803/1871. - Csanád vármegye; 21068/1871. - Csongrád vármegye; 21272/1871. - Doboka vármegye; 17808/1871. - Fejér vármegye; 22026/1871. - FelsőFehér vármegye; 21800/1871. - Fogaras vidék; 217981/1871.-Zala vármegye; 118. 23346/1871. Alsó-Fehér vármegye; 22592/1871. - Bereg vármegye; 23816/1871. - Gömör és Kis-Hont vármegye; 28726/1871. - Hont vármegye; 22499/1871. - Kővár vidék; 22336/1871. - Veszprém vármegye.

${ }^{1041}$ MNL BM K150 117.21272/1871.; 118. 22499/1871.
} 
valamint Kövár vidék hiába kívánta csökkenteni a közigazgatási költségeit, ennek ellenére sem tudták betartani a számukra biztosított pénzügyi keretet. ${ }^{1042}$

Számos törvényhatóság emiatt abban bízott, hogy legalább az 1870. évi költségvetésüknek megfelelő pénzösszeget változatlanul megkapják a kormányzattól, így csak az e határon túlterjeszkedő vármegyék kényszerülnének újabb adók kivetésére. ${ }^{1043}$ Ehhez hasonló megoldás lett volna, ha az egyes vármegyékben eltérő adókulcsokat megállapítva ugyanakkora összeghez juttatnák a törvényhatóságokat. ${ }^{1044}$ Arad vármegye a pénzügyminiszteri rendelet által biztosított kereten átlépve szintén a belügyminisztertől kérte a szükséges anyagi feltételek megteremtését államsegély formájában. ${ }^{1045}$ Alsó-Fehér, Gömör és Kis-Hont, valamint Veszprém vármegye a tervezett adócsökkentéssel megvalósuló finanszírozási elképzelést hibásnak tartotta, mivel így több területi önkormányzat még takarékoskodhatna is a befolyó pénzösszegből, míg másoknak aránytalan mértékű adókat kellene kivetniük, amelyre véleményük szerint a kisebb törvényhatóságok nem lesznek hajlandók. ${ }^{1046}$ Gömör és Kis-Hont vármegye kijelentette, hogy ez a megoldás „a felsőbb zordonabb éghajlatu ’s rosszabb talajú, vagy kisebb kiterjedésủ megyéket sújtja." ${ }^{047}$

Alsó-Fehér vármegye a pénzügyi problémák rendezése érdekében „odáig merészkedett”, hogy a korábban erőteljesen ellenzett vármegyei területek átszabását javasolta az országgyűlés számára. ${ }^{1048}$ Gömör és Kis-Hont vármegye pedig úgy vélte a hiányzó pénzösszeget pótolhatná, ha az ipartevékenységet végző vállalatok (különösen a szeszgyárak) által fizetett közvetett adót is hozzászámítanák a kiindulási alaphoz. ${ }^{1049}$ Doboka vármegye más

1042 MNL BM K150 117. 20171/1871.; 21272/1871.; 21798/1871.; 118. 23346/1871.; 22336/1871.; $22499 / 1871$.

1043 "[J]ogosult reménye lehet minden alkotmányos kormány iránt - loyális megyénknek arra nézve, hogy közvetve az egész országot illetö közigazgatási költségeinek terhe nem saját lakóira kivetett pótlék, hanem miként méltányos is, az országos pénztárból fog fedeztetni, amúgy pedig az országos dotatiotól nagyobbára elesnék, söt esetleg még ö járulna más megyék gazdagabban dijazott tisztviselöik fizetésébez" - MNL BM K150 118. 31986/1871. - Hont vármegye; 31726/1871. - Alsó-Fehér vármegye; 23816/1871. Gömör és Kis-Hont vármegye; 22499/1871. - Kővár vidék; 22336/1871. - Veszprém vármegye; 117. 20171/1871. - Aranyosszék; 21799/1871. - Bars vármegye.

1044, „[A]zállam érdekében szükségesnek tartjuk, hogy a törvény hatóságok adója külön-külön, ha nem magasabb, legalább azon összegig szállittassék le, mely összeg minden törvényhatóságnak egyenként, közigazgatási szükségletekre az állam részéröl 1870-ben engedélyeztetett." - MNL BM K150 118. 23346/1871. - AlsóFehér vármegye.

1045 MNL BM K150 117.32702/1871.

1046 „Kisegito" módozatról elóre óbajtunk gondoskodni, - miután, úgy saját gazdálkodó eljárásunk daczára mint több testvér törvényhatóságnak a tárgyban hozzánk küldött átiratából is, a közigazgatási költségek megszabásánál alkalmazott kulcs hibás voltáról gyözödtünk meg mig egyes megyékre nézve a kulcs igenis elönyös, a többekben, eredményét tekintve, használhatlanná válik." - MNL BM K150 118. 22336/1871. - Veszprém vármegye; 23346/1871. - Alsó-Fehér vármegye; 23816/1871. - Gömör és Kis-Hont vármegye.

${ }^{1047}$ MNL BM K150 118. 23816/1871.

1048 „Megvagyunk gyöződve hogy ha a rendezést a törvényhatóságok czélszerübb és egyformább kikerekitése elözte volna meg, ezen nehézségek nem forognának fen.” - MNL BM K150 118. 23346/1871. - Alsó-Fehér vármegye.

${ }^{1049}$ MNL BM K150 118. 23816/1871. 
megoldási lehetőség hiányában kérte a Képviselőházat, hogy a törvényhozás a vármegyék esetében továbbra is tartsa fenn az államsegélyezés rendszerét. ${ }^{1050}$

A belügyminisztérium szintén Doboka vármegye számára kifejtette, hogy a személyes kereseti adóból számított pénzösszeg felhasználására vonatkozó kérelmét nem tudja elfogadni, mivel a törvényhozó kötelezően az egyenes adók 7,76 \%-ából kívánja fedezni a közigazgatási költségeket az egyes vármegyékben. ${ }^{1051} \mathrm{~A}$ belügyminisztérium tehát egyértelműen úgy foglalt állást, hogy a törvényhatóságok a pénzügyminisztérium második kalkulációját nem alkalmazhatják. A minisztérium Veszprém vármegyének szóló leirat tervezetéből kitűnik, hogy a tanácsosok is kétségesnek tartották a törvény megvalósíthatóságát e keretek között, azonban ennek ebben az esetben nem kívántak hangot adni a vármegye irányába. ${ }^{1052} \mathrm{~A}$ törvényhatóságok számára küldött anyagi jellegű figyelmeztetésekbe viszont belefoglalták a némi kételyt tükröző „ha csak a törvényhozás máskép nem fog intézkedni” szövegrészt. ${ }^{1053}$ Aranyosszék esetében viszont konkrétan állást foglalt a belügyminisztérium, amelyben kifejtették, hogy szükséges a pénzügyi problémák megoldása, azonban a törvényi rendelkezés miatt erre csak a törvényhozás jogosult. ${ }^{1054}$ A minisztériumi tanácsosok Doboka vármegye főispánja számára már szabadon kinyilvánították véleményüket: „A törvényhatósági költségek kivetésének alapja tárgyában sok más megye részéröl is érkezik hozzám fölterjesztés, némelyek ezek közöl a személyes kereseti adót kivánják alapul vétetni, mások pedig az 1870 és 1871 ik évben a kormány által engedélyezett évi javadalmazás további kiszolgáltatását kérik. Részemröl is elismerem miként az 1870ik évi 42.tcz. folytán némely törvény hatóság jelesül Doboka megye is adó kivetés tekintetében terhelve lenne és hogy ezen segiteni mint a közigazgatás rendes menetének érdekében kivánatos, minthogy azonban eziránt törvény rendelkezik annak e részben határozata csak a törvényhozás utján változtatható meg." 1055

Gömör és Kis-Hont vármegye azzal magyarázta az állami finanszírozás szükségességét, hogy a közigazgatás „már csak személy és vagyonbiztonság tekintetéböl is, az igazságszolgáltatással hasonló fontosságú országos érdek lévén, méltányos, hogy annak költségei az ország törvényhatóságai által aránylagosan viseltessenek." ${ }^{1056}$ A törvényhatóság a végrehajtás során ennek megfelelően a belügyminisztériumnak küldött utolsó válaszában is fenntartotta annak lehetöségét, hogy a törvényhozás vagy a belügyminisztérium az egységesség követelménye miatt végül a tisztviselői fizetések állami utalványozása mellett fog dönteni. ${ }^{1057}$

\footnotetext{
${ }^{1050}$ MNL BM K150 117.29721/1871.

${ }^{1051}$ MNL BM K150 117.21272/1871.

1052 "[M]ég csak a törvényhatósági költségek fedezésére nézve kivánom kijelenteni, hogy ámbár részemröl is az 1870 évi XLII. t.cz. 11 és 90 SSainak alkalmazását egyes törvényhatóságokra sezek közt a közönség által képviselt megyére is terhelönek találom, sezen segiteni magam is, mind a közigazgatás, mind az adozok érdekében kivánatosnak látom, mindamellett ez irányban a törvényhozás további intézkedéséig bárminemü változtatást tenni, hatáskörömön tul állonak tartom."(A leirat végső szövegéből kihúzva.) - MNL BM K150 118. 22336/1871.

1053 MNL BM K150 117. 17731Sz/1871. - Arad vármegye; 118. 22592/1871. - Bereg vármegye; 23346/1871. - Alsó-Fehér vármegye; 28726/1871. - Hont vármegye.

${ }^{1054}$ MNL BM K150 117.20171/1871.

1055 MNL BM K150 117.29721/1871.

1056 MNL BM K150 118. 23816/1871.

1057 MNL BM K150 118. 32051/1871.
} 
A közigazgatással foglalkozó szakemberek és jogtudósok egyetértettek abban, hogy az önkormányzatiság fontos biztosítéka az önálló adóbevételekkel való rendelkezés, mivel a folyamatos államsegélyezés esetében nem lehet szó a központi kormányzattól való függetlenségről. ${ }^{1058}$ Gömör és Kis-Hont vármegye az előbbiekben citált érvelésével azonban egyet kell értenünk, mivel az államigazgatási teendőket is ellátó vármegyéktől nem várható el, hogy az önkormányzati jog biztosítása okán a teljes helyi igazgatási terheket viseljék. Ezt végül az országgyűlés is belátta, így a törvény e rendelkezéseit 1871-től minden évben felfüggesztették és fenntartották az államsegélyezés intézményét. ${ }^{1059}$ Végső megoldásként az 1883:XV. tc. intézményesítette az államsegélyezést, mivel az adóztatási képességek egységesítéséhez szükséges területi átszervezések csak részben valósultak meg. ${ }^{1060}$

A vármegyei közigazgatás így a továbbiakban is az államsegélyezésre támaszkodott, amely annak fényében különösen érdekes, hogy a járási szervezet kialakítása során a belügyminisztériumnak a vármegyék részére küldött figyelmeztetései a finanszírozási korlátokról üres fenyegetésnek bizonyultak. Ennek kapcsán azonban érdemes megjegyezni, hogy ugyan Ereky István lesújtó képet festett az államsegélyezés fenntartásáról és ezzel a valódi önkormányzati jogosultságok elvonásáról, ${ }^{1061}$ de a vármegyék részéről emiatt a legkisebb ellenkezés sem tapasztalható az általam vizsgált iratokban.

\subsection{A tervezetek megerősítését végző belïgyminisztériumi tanácsosok}

A köztörvényhatósági törvény 91 . \$-a a vármegyei tervezetek megerősítését a Magyar Királyi Belügyminisztérium hatáskörébe utalta, amelynek vezetését az 1870:XLII. tc. végrehajtása idején Tóth Vilmos látta el. A belügyminisztérium egységesítési törekvéseinek megvalósításához nagyban hozzájárult a hivatalban működő, külön erre a célra kialakított ügyfeldolgozási módszer. Az egyes törvényhatósági tervezetek már korábban említett pontonkénti előterjesztése amiatt is előnyös volt ${ }^{1062}$ mivel a minisztérium egyes osztályainak ezáltal lehetősége nyílt az egyes résztervezetek elbírálását felosztani egymás között.

A törvényhatósági bizottsági választásokkal kapcsolatos tervezetek elbírálásával (választókerületek kialakítása, virilisek összeírása) a III. ügyosztályt (közjogi) bízták meg. ${ }^{1063}$ A szolgabírói járások és a közigazgatási szervezet kiépítéséről szóló vármegyei munkálatok megerősítését pedig a belügyminisztérium $V$. ügyosztálya végezte, amely feladata a megyei

\footnotetext{
1058 MÁTHÉ 2006, 263.; KI 1872. X. k. 51.; EnQUeTe 188. Báró Majthényi László felszólalása, 192. Komjáthy Béla felszólalása; CoNCHA 1928, 310.

1059 Cieger 2005, 51.

1060 Ereky, 1910, 81-93.; Szivessy 1933, 10-11.; Stipta 1995b, 156-159.

1061 EREKY 1910, 81-93.

1062 L. 5.7. pont.

${ }^{1063}$ MNL BM K150 117.21100/1871.; 21265/1871.; HELYSÉGNÉVTÁR 5.
} 
háztartási ügyek intézése volt. ${ }^{1064}$ Ennek fényében érthető, hogy a belügyminisztériumi megerősítéseket tartalmazó leiratokban megjelenő legfontosabb szempont a közigazgatási szervezet finanszírozásával kapcsolatos kérdések voltak, míg a járási szervezet egységesítése vagy éppen a vármegyék közjogot érintő felvetései háttérbe szorultak.

A tervezeteket megerősítő, vagy azok módosítását kérő belügyminisztériumi leiratok esetén a minisztériumi hivatalnok először egy előfogalmazványt készített, amelyet utána az osztályvezető ellenőrzött le. A közigazgatási szervezetekről készített tervezetek esetén az előfogalmazványokat Kerekes Ágoston, ${ }^{1065}$ Csávosy Béla ${ }^{1066}$ és két aláirása alapján nem azonosítható tisztviselő készítette, míg azok ellenőrzését minden alkalommal Torkos László osztálytanácsos végezte. ${ }^{1067}$ Torkos László személyének egyértelmü meghatározását megnehezítette, hogy a tervezeteket csupán vezetéknevének feltüntetésével írta alá, és a minisztériumban vele egyidőben dolgozott Torkos Kálmán is. ${ }^{1068} \mathrm{Az}$ Arad vármegye tervezetének minisztériumi átiratán feltüntetett megjegyzés alapján azonban egyértelműen azonosítható. ${ }^{1069} \mathrm{~A}$ belügyminisztériumi munkálatok során tapasztalható egységes követelmények meghatározása, így az ő közös munkájukat dicséri. Ennek köszönhető az, hogy a bemutatott tervezetek esetében a belügyminiszteri leiratok szó szerint ugyanazokkal a fordulatokkal operálnak.

Torkos László a korszakban tipikusnak számító hivatalnoki pályát futott be. 1835. március 25-én született az ócsai Torkos dunántúli, birtokos nemesi családban. Apja Torkos Mihály, édesanyja Würtzler Ludovika volt. Torkos Mihály gyorsan ívelő vármegyei karrierje csúcsán, 1836-ban Moson vármegye követe volt a Karok és Rendek Tábláján. Ezt köve-

1064 MNL BM K150 117. 17731Sz/1871.; 17803/1871.; 18194/1871.; 18839/1871.; 20171/1871.; 20826/1871.; 20991/1871.; 21068/1871.; 21161/1871.; 21272/1871.; 21797/1871.; 21798/1871.; 21799/1871.; 21800/1871.; 22026/1871.; 22226/1871.; 27062/1871.; 27079/1871.; 27282/1871.; 27291/1871.; 28287/1871.; 28525/1871.; 29328/1871.; 29721/1871.; 31267/1871.; 31913/1871.; 32636/1871.; 32702/1871.; 32776/1871.;34430/1871.; 118. 22326/1871.; 22336/1871.; 22499/1871.; 22592/1871.; 22691/1871.; 23346/1871.; 23816/1871.; 25309/1871.; 25636/1871.; 27001/1871.; 28726/1871.; 28989/1871.; 30172/1871.; 30266/1871.; 30274/1871.; 31404/1871.; 31726/1871.; 31986/1871.; 32051/1871.; 33141/1871.; 34064/1871.; HELYSÉGNÉVTÁR 7.; BK 1869/136. 1883.

1065 MNL BM K150 117. 21068/1871.; 21161/1871.; 21798/1871.; 21799/1871.; 27282/1871.; 27291/1871.; 28287/1871.; 28525/1871.; 29328/1871.; 31267/1871.; 32702/1871.; 34430/1871.; 118.22326/1871.; 22499/1871.; 27001/1871.; 28989/1871.; 30266/1871.; 30274/1871.; 31726/1871; $34064 / 1871$.

1066 MNL BM K150 117.31913/1871.; 29721/1871.; 118. 28726/1871.

${ }^{1067}$ MNL BM K150 117. 17731Sz/1871.; 17803/1871.; 18194/1871.; 18839/1871.; 20171/1871.; 20826/1871.; 20991/1871.; 21068/1871.; 21161/1871.; 21272/1871.; 21797/1871.; 21798/1871.; 21799/1871.; 21800/1871.; 22026/1871.; 22226/1871.; 27062/1871.; 27079/1871.; 27282/1871.; 27291/1871.; 28287/1871.; 28525/1871.; 29328/1871.; 29721/1871.; 31267/1871.; 31913/1871.; 32636/1871.; 32702/1871.; 32776/1871.;34430/1871.; 118.22326/1871.; 22336/1871.; 22499/1871.; 22592/1871.; 22691/1871.; 23346/1871.; 23816/1871.; 25309/1871.; 25636/1871.; 27001/1871.; 28726/1871.; 28989/1871.; 30172/1871.; 30266/1871.; 30274/1871.; 31404/1871.; 31726/1871.; 31986/1871.; 32051/1871.; 33141/1871; 34064/1871.

1068 NÉvTÁr 63.

1069 „A felterjesztés 2ik pontját [a szolgabirói járások visszaküldését kérte] illetöleg lássa mgs Torkos László oszt. tan. úr. - Láttam, 's a szoban lévö munkálat f.é. 17731. sz. a. a megyének kiigazitás végett megküldetett. - Torkos" - MNL BM K150 117. 18194/1871. 
tően a központi kormányzatban vállalt jelentős hivatalokat. 1849-ben a Helytartótanács másodelnöke, 1851-től 1861-ig a Legfőbb Császári Ítélőszék magyar osztályának elnöke, majd pályája végén 1861-ben a Hétszemélyes Tábla elnöke lett. ${ }^{1070}$ Fia, Torkos László a budai cs. k. helytartósági osztály fogalmazó gyakornokaként kezdte pályáját, majd 1858 nyarán a budai közigazgatási kerület politikai szolgabírói hivatalának segédévé nevezték ki, ${ }^{1071}$ ahonnan 1859-ben ismételten a magyarországi cs. k. helytartósághoz nevezték ki fogalmazói beosztásba. ${ }^{1072} \mathrm{Az}$ októberi diplomát követően is megmaradt központi államhivatalnoki beosztásban Torkos László, ugyanis adatolhatóan valóságos másodosztályú fogalmazóvá nevezte ki a m. k. helytartótanácshoz a magyar udvari kancellária, ${ }^{1073}$ amelyet követően 1864-ben a m. k. helytartótanács vízépítészettel és bányászattal foglalkozó 5 . ügyosztályában foglalkoztatták. ${ }^{1074}$

A kiegyezés nyomán újjáalakuló magyar kormányban 1867. május 22-ével belügyminisztériumi fogalmazóként kezdte pályáját minden bizonnyal a m. k. helytartótanácsból átlépve, ${ }^{1075}$ mindösszesen kilenc nap múlva az uralkodó már tiszteletbeli titkárrá nevezte ki. ${ }^{1076} 1867$. június 8-án pedig megkoronázása alkalmából Ferenc József aranysarkantyús vitézzé avatta. ${ }^{1077} \mathrm{~A}$ következő év januárjában a belügyminiszter elöterjesztésére miniszteri titkárrá léptették elö. ${ }^{1078} 1869$ júniusától bizonyíthatóan az V. ügyosztályt vezette, így a megyei háztartással kapcsolatos ügyek tartoztak a feladatkörébe. A minisztériumi részleg a törvényhatóságok költségvetéseinek felülvizsgálatát és az államsegélyek utalványozását végezte. ${ }^{1079}$

Éppen az 1870:XLII. tc. végrehajtásának időszakával esett egybe osztálytanácsosi kinevezése, mivel 1871. június 7-én írta alá az uralkodó az erről szóló rendeletét, amelyet Tóth Vilmos belügyminiszter ellenjegyzett. ${ }^{1080} 1885$-ben már Tisza Kálmán terjesztette fel belügyminiszterként nevét a király számára abból a célból, hogy osztálytanácsosként miniszteri tanácsosi címet és rangot kapjon. ${ }^{1081} 1886$-tól a IV/b. Községi osztály vezetését vette át, ${ }^{1082}$ ahol áldozatos munkájának köszönhetően az 1887-ben létrejött magyar-román határszakaszról szóló megállapodás során szerzett érdemeiért a román királyi csillagrend középkeresztjét és a magyar királytól a Lipót-rend lovagkeresztjét kapta meg. ${ }^{1083}$ Ennek jutalmaként 1889-ben Teleki Géza belügyminiszter előterjesztése nyomán valóságos

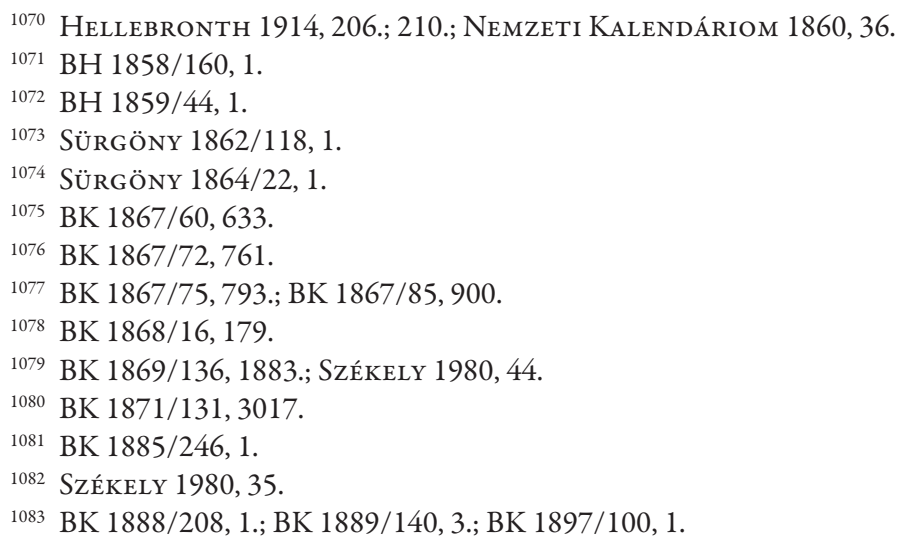


miniszteri tanácsossá nevezték ki, ${ }^{1084}$ amellyel elérte Torkos hivatali pályájának csúcsát. 1891-től 1896-ig a II. számú (vármegyei) főosztály vezetője lett, ${ }^{1085}$ majd 1896. december 14-én saját kérelmére nyugállományba vonult. ${ }^{1086}$

Torkos László a szintén nemesi családból származó, nála hat évvel idősebb Balassa Emíliát vette feleségül, akitől öt gyermeke született, akik közül kettő még csecsemőkorában életét vesztette. ${ }^{1087} \mathrm{Fia}$, ifj. Torkos László követve apját szintén a belügyminisztériumban dolgozott, ahol miniszteri segédtitkári címig vitte. Budapesten a Váci körút (ma Bajcsy-Zsilinszky út) 17. szám alatt élt a család. A nyugdíjas éveit töltő miniszteri tanácsost 1905-ben nagy csapás érte, ugyanis fia születésnapján öngyilkosságot követett el. ${ }^{1088}$ Érdemes még megjegyezni, hogy Torkos Lászlónak távoli rokona volt a már említett szintén a belügyminisztériumban dolgozó Torkos Kálmán és a szintén a Torkos László nevet viselő ismert költő. ${ }^{1089}$ Torkos László minden bizonnyal emblematikus alakja volt a belügyminisztériumnak, ugyanis Herman Ottó publicisztikájában az ottani ügyintézés kapcsán az ő alakját elevenítette fel, mint a bürokratikus ügyintézés „nagy barátját”. ${ }^{1090}$

Kerekes Ágoston Torkoshoz hasonlóan ősi nemesi családból került ki, ősei elsősorban Északkelet-Magyarországon szereztek hírnevet. ${ }^{1091}$ 1821-ben született Kerekes István vármegyei főpénztárnok és Konecsny Katalin gyermekeként. ${ }^{1092}$ Kerekes Ágoston Hajdú vármegye főszolgabírája és a Hétszemélyes Tábla jegyzője is volt. A neoabszolutizmus időszakában betöltött tisztségei nehezen azonosíthatók minden bizonnyal maradt a vármegyei pályán, mivel Ung vármegyében az 1850-es évek második felében Kerekes Ágoston névvel töltötték be a kiadói tisztséget, ${ }^{1093}$ míg 1864-ben a cs. kir. szolgabíró hivatali segédi pozícióból nevezte ki a magyar kir. udv. kancellária a m. k. helytartótanács valóságos fogalmazójává. ${ }^{1094}$ Innen vált belügyminisztériumi fogalmazóvá a kiegyezést követően, ${ }^{1095}$ ahol 1869-ben már Torkos László munkatársaként dolgozott a megyei háztartással foglalkozó V. osztályon. ${ }^{1096} 1872$ februárjában

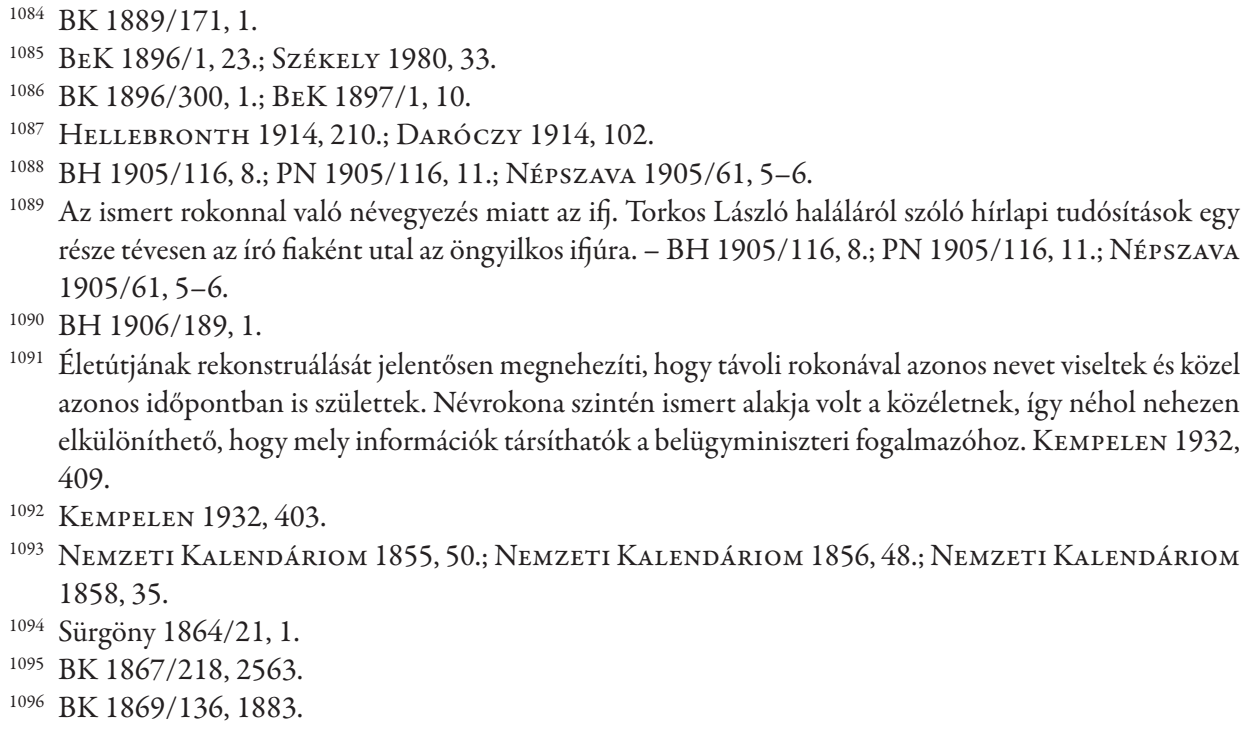
része tévesen az író fiaként utal az öngyilkos ifúra. - BH 1905/116, 8.; PN 1905/116, 11.; NÉPSZAVA $1905 / 61,5-6$.

1090 BH 1906/189, 1.

${ }^{1091}$ Életútjának rekonstruálását jelentősen megnehezíti, hogy távoli rokonával azonos nevet viseltek és közel azonos időpontban is születtek. Névrokona szintén ismert alakja volt a közéletnek, így néhol nehezen elkülöníthető, hogy mely információk társíthatók a belügyminiszteri fogalmazóhoz. KEMPELEN 1932, 409.

1092 Kempelen 1932, 403.

1093 NemZeti KalendáRiom 1855, 50.; NemZeti Kalendáriom 1856, 48.; Nemzeti Kalendáriom 1858,35 .

1094 Sürgöny 1864/21, 1.

1095 BK 1867/218, 2563.

${ }^{1096}$ BK 1869/136, 1883. 
titkárrá léptették elő, ${ }^{1097}$ ahonnan jelenlegi adataim szerint 1873-ban távozott. ${ }^{1098}$ Kerekes Ágoston végül 1887-ben hunyt el. ${ }^{1099}$

Kerekes Ágoston és Torkos László pályájának jelentős része a központi kormányzathoz kötődött, sőt Torkos Lászlóé a belügyminisztériumban teljesedett ki. Csávosy Béla ettől jelentősen eltérő életutat járt be. Csávosy Ignácz gyermekeként 1848. szeptember 12-én Temesváron látta meg a napvilágot. ${ }^{1100}$ Családjának 1867-ben adományozott nemesi címet az uralkodó. ${ }^{1101}$ Középiskolai tanulmányait a Kegyes Tanítórendiek Pesti Nagy Gymnasiumában végezte, ${ }^{1102}$ majd a pesti egyetemen szerezte diplomáját. ${ }^{1103}$ Jogi tanulmányai alatt országgyűlési gyakornokként is dolgozott, ${ }^{1104}$ az egyetem befejezését követően pedig 1870-ben Torontál vármegye tiszteletbeli aljegyzőjeként helyezkedett el, majd 1871 januárjában a belügyminisztérium tiszteletbeli segédfogalmazójává nevezte ki az uralkodó Rajner Pál előterjesztése nyomán. ${ }^{105}$ Rövid ideig állt a belügyminisztérium alkalmazásában, ugyanis politikai pályára lépett, miután 1875-ben Torontál vármegye párdányi kerületének országgyủlési képviselőjének választották a Szabadelvű Párt jelöltjeként. 31 éven kereztül volt a választókerület országgyưlési képviselöje, sőt több mint tíz éven keresztül a Képviselőház háznagyi tisztét is ellátta. ${ }^{1106}$ 1904-ben bátyját és családját bárói címmel tüntette ki az uralkodó, amelyet 1911-ben rá is kiterjesztettek. A bárói cím megszerzésétől használta a Csávossy vezetéknevet, emiatt 1915-ben bekövetkező halálakor már így azonosították. ${ }^{1107}$ Csávosy pályájának ismeretében elmondható, hogy a belügyminisztériumi munkája csupán „ugródeszkát” jelentett számára később kibonatkozó karrierjéhez.

Torkos és Kerekes a neoabszolutizmus időszakában gyakorlatot szerző tisztségviselőkként nyilvánvalóan magukénak érezhették a modern közigazgatás azon alapelveit, amelyeket a 19. század közepén dolgoztak ki és érvényesítettek először, így hatékonyan valósíthatták meg azokat a dualizmus kori járási szervezet kiépítése során. Csávosy pályakezdő, frissen kinevezett segédfogalmazóként nem valószínű, hogy jelentős befolyást gyakorolt volna a belügyminisztériumi gyakorlatra. A Torkos és Kerekes nemzetség bemutatása rámutat arra, hogy a vármegyei tisztikarokban megfigyelhető tisztviselö „dinasztiák” a központi kormányzatban is megjelentek, ${ }^{1108}$ amelynek köszönhetően a vármegyei hivatalnokokhoz hasonlóan a minisztériumban is megőrizte pozícióit az egykori nemesi elit. ${ }^{1109}$

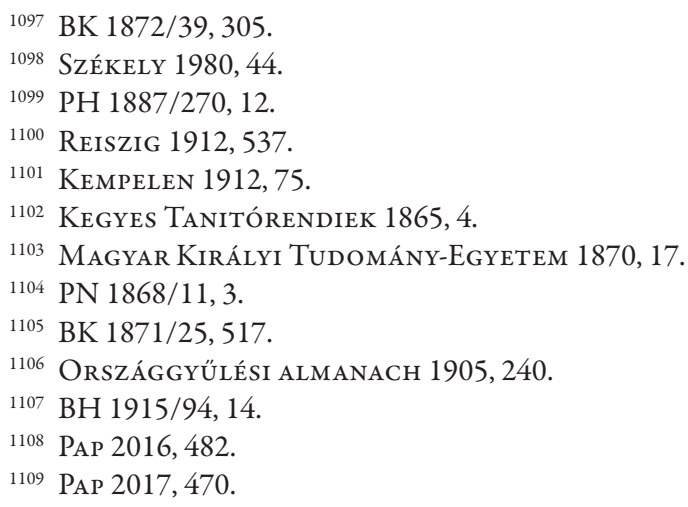




\section{2. ÖSSZEGZÉS}

A köztörvényhatóságokról szóló 1870:XLII. tc. hiába végezte el a közigazgatási szervezet kodifikációját, az országgyülés ennek keretei között a járási szervezetet csak néhány elemében, mindössze két szakasz erejéig szabályozta, így csupán annak alapvonalait fektette le. A járások területének, a szolgabírák fizetésének, vagy a járási tisztviselők hatáskörének központi meghatározása és törvénybe foglalása elmaradt, mivel ezt a törvényhatóságok hatáskörébe utalta a jogalkotó. A neoabszolutizmus kori járási rendszert szabályozó rendeletéhez hasonló részletességü joganyag tehát nem született a vizsgált időszakban, de a rendi korszakból örökölt szétaprózódott szabályokhoz képest a járásokra vonatkozó rendelkezések összefogottabbá váltak. A vármegye életében a 13. században megjelent szolgabírói tisztséget a rendi korhoz és a neoabszolutizmus korszakához hasonlóan a kiegyezést követően is megőrizte a köztörvényhatósági törvényben az országgyülés.

A szolgabírói hivatalok lényeges változásokon mentek keresztül a kiegyezést követően, mivel az 1869:IV. tc. elvonta a járási tisztviselőktől az igazságszolgáltatási hatásköreiket. Emellett pedig a kiegyezés közjogi rendszerének megfelelően szervezték át az ország közigazgatását. Az új járási szervezet kiépítését a jogalkotó azonban nem központilag szabályozta, hanem a vármegyei törvényhatóságok hatáskörébe utalta. A járási felosztás kapcsán kijelenthető, hogy a törvényhatóságok éltek szervezetalakítási szabadságukkal és a rendi korszakhoz hasonlóan egymástól jelentősen eltérő szolgabírói járásokat hoztak létre. Az erôteljes vármegyei autonómia-igényt igazolja, hogy a tervezeteket létrehozó küldöttségek és vármegyei közgyủlések (állandó bizottmányok) jelentős része a jogalkotó akaratával szembehelyezkedve a járások határainak megállapításakor nem vette figyelembe az országos választókerületeket. A belügyminisztérium sem igazán szorgalmazta azonban, hogy a vármegyék a törvény rendelkezéseinek megfelelően járásaikat a választókerületekhez igazítsák. Több vármegye is inkább a járásbírósági beosztáshoz kívánta igazítani közigazgatási szervezetét. A vármegyei munkálatok során azonban a különböző hatóságok kerületeivel történő koordináció nem jelent meg kiemelt szempontként. Emiatt cáfolható Vizsolyi Gusztáv országgyủlési képviselőnek az 1880. évi közigazgatási ankéton elhangzó azon nézete, hogy erre a minisztérium felhívta a törvény végrehajtása alkalmával a vármegyéket és az megvalósult volna a legtöbb megyében. ${ }^{1110} \mathrm{~A}$ leggyakoribb hivatkozási alap a tervezetekben a szolgabírói illetékességi területek kialakítása kapcsán a vármegye földrajzi fekvése, a közlekedési nehézségek és a különböző természeti akadályok voltak.

Az egyes járások lakosságszáma jelentős eltéréseket mutattak, jellemzően harmincezer fö alatti közigazgatási egységeket hoztak létre, de ezen belül igen nagy szórást mutatott a területi beosztás. A változékony járási szervezet oka a partikuláris szabályozási mód mellett a törvényhatóságok egyenlőtlen mérete volt, ami megnehezítette az egységes szervezet létrehozását. A járások elnevezései ekkor a 19. században kialakult szokásnak megfelelően jellemzően a területi egység nagyobb városaihoz igazodtak, amelyeket állandó

1110 Enduete 199-200. 
jelleggel alkalmaztak. A törvényhatósági jogú városok nem képezték a járási szervezet részét, amely megoldást a vármegyék is alkalmaztak. A rendezett tanácsú városok a törvényi szabályozás szerint szintén függetlenek voltak a szolgabírák müködésétől, azonban ennek következetes érvényesülése nem követhető nyomon a levéltári forrásokban. A járások mint területi egységek tehát nem mutatnak egységes képet a lakosságszám vagy a területet meghatározó tényezők esetében, mivel a belügyminisztérium nem lépett fel ennek érdekében.

A járási székhelyek meghatározására a legtöbb vármegye a törvény által kínált lehetőségnek megfelelően nem törekedett. A vizsgált törvényhatóságoknak azonban több mint a negyede vagy a székhelyek meghatározásával, vagy esetleg más megoldással (Fejér, Doboka, Felső-Fehér) igyekezett túllépni azon a rendi korból származó szokáson, hogy a járási székhely és a járási ügyek intézésének a helye a szolgabíró lakhelyéhez igazodik.

A magyar közigazgatási szervezet a nagyfokú önkormányzati autonómiára épült az 1870:XLII. tc. elfogadása után is. A teljesen egységes polgári közigazgatás létrehozása azonban lehetetlennek tűnt a magyar ősi vármegye centralizációban való feloldása nélkül, a törvényhatóságok munkálatainak belügyminisztériumi ellenőrzése viszont megfelelő eszköznek bizonyult a polgári közigazgatás létrehozásához szükséges egységesség megteremtéséhez. A belügyminiszteri tanácsosok ennek segítségével a törvénybe ütköző, az alsó középszintű közigazgatás polgári alapelvek alapján való átszervezését sértő megoldásokat képesekké váltak kiszürni.

A belügyminisztérium így az egységes járási szervezet kiépítése érdekében a járások további alegységekre bontását elutasították a köztörvényhatósági törvény rendelkezéseire hivatkozva. A korábban gyakran kétszintủ vármegyei területfelosztást ezáltal egyszintűvé alakították, mivel a rendi korban kialakult, így az októberi diplomát követően ismételten megjelenő kerületeket kiiktatták. Ezzel a neoabszolutizmusban létrehozott közigazgatáshoz hasonló felépítésủ szervezetet teremtettek. A miniszteri tanácsosok a vármegyei tervezetekben nem engedélyezték ennek használatát. A közigazgatási egységeket állandó jelleggel járásként nevezték meg. Az ettől eltérő elnevezéseket viszont csupán mintegy mellékesként javították.

A szolgabírói hivatalok létrehozása kapcsán ugyanez az egyformaságra törekvés volt tapasztalható, azonban ennek kapcsán sokkal határozottabban léptek fel a belügyminisztériumi megerősítés alkalmával. A járásokat vezetô tisztviselő szolgabírói megnevezéséhez konzekvensen ragaszkodtak a tanácsosok, a rendi korszakból fennmaradt fószolgabírói titulus további használatát nem engedélyezték. A föszolgabírói elnevezésre vonatkozó kifejezett elutasítás okán úgy vélem, hogy téves az a megoldás, miszerint az 1886:XXI. tc.-ben alkalmazott föszolgabírói elnevezést egységesen a teljes dualizmus időszakának járást vezető tisztviselőire használják. ${ }^{1111}$ A rendi jellegű tisztségek (alszolgabíró és esküdt) kiiktatásra kerültek, amelyeket a vármegyei institúció helyreállítását követően a legtöbb vármegye az új közigazgatási szervezet hatályba lépéséig alkalmazott. A vármegyék többsége az 1870:XLII. tc.-ben engedélyezett, a szolgabíró által kinevezendő szolgabírói írnokokat rendszeresítette járási hivatalaiban.

1111 VÖRÖS 1956, 14.; BARTA 2012, 28-29. 
A vármegyék egy része azonban hiányolta a szolgabíró és a szolgabírói írnok közötti átmenetet, amely igényt a belügyminisztérium a szolgabírósegéd meghonosításával elégítette ki. Ezzel egy a rendi hagyományoktól eltérő tisztséget emeltek be, aminek előképe a neoabszolutizmus járási hivatalában fedezhető fel. E megállapítást igazolja, hogy a járási szervezet kialakításában nagy szerepet játszó belügyminiszteri tanácsos, Torkos László közigazgatással kapcsolatos első tapasztalatait az 1850-es évek második felében szerezte, így jól ismerhette e korszak adminisztratív megoldásait. A szolgabírósegédeket a belügyminisztérium szándéka szerint a föispán nevezte ki, ezáltal csökkentették a vármegye önkormányzati szervei által választott tisztségeket, mivel az alszolgabírákat egyértelmüen a vármegyei közgyủlés juttatta pozíciójukba a rendi korszakban.

A szolgabírák közszolgálati jogállása is átalakult a korábbiakhoz képest, a hagyományosnak tekinthető hároméves tisztviselöi mandátumukat ugyanis hat évre emelték fel. A szolgabírói fizetéseket a vármegyék általában a korábbi szinten tartották, így némi bérfeszültség alakult ki az államilag javadalmazott bírákkal szemben. A törvényhatósági tisztviselők között az anyagilag elismert hivatalok közé tartozott. A 19. század első felében a megbecsültséget tekintve a vármegyei tisztikarban elfoglalt pozícióját megőrizte a polgári átmenetet követően is. Emellett úgy tűnik, hogy valós célkitüzés volt a közigazgatási kiadások mérséklése is, amelyet sikerült megvalósítani a vármegyék függetlenségének tiszteletben tartása mellett, mivel a legtöbb vármegye csökkentette a járási szervezetben dolgozók létszámát és érdemben a fizetésüket sem növelték. A belügyminisztérium azonban meg sem kísérelte a vármegyei tervezetekben egységesíteni a szolgabírák fizetéseit, napidíjait, előfogati díjait vagy akár szabadságuk időtartamát, szórványosan a túlzott mértékü pénzösszegeket korrigálták. Ez abba az irányba mutat, hogy a tisztviselők fizetésének, munkafeltételeinek egységesítése nem volt célja a belügyminisztériumnak, így nem törekedtek a neoabszolutizmus mintájára hivatalnokréteg kialakítására a vármegyékben.

A vármegyei munkálatok alapján kijelenthető, hogy a belügyminisztériumnak a járási szervezetre vonatkozó szabályozással nem csupán a fennálló állapotok konzerválása volt a célja. A szabályozás előtti vármegyei állapotok arra mutatnak, hogy jelentős átalakításokat hajtott végre a jogalkotó az új szabályozás elfogadásával. A szolgabírói hivatalból kiiktatásra került a korábbi tisztviselők jelentős része (alszolgabíró, esküdt), így az igazságszolgáltatási szervezet átalakításához hasonlóan járási szinten az egyszemélyi felelősség lépett az együttes eljárás helyébe. Emellett a vármegye alatti közigazgatási szintet is egyszintűvé alakította, így ilyen tekintetben inkább a neoabszolutizmus közigazgatási szervezetével vonható párhuzam. A hatáskörök terén viszont nem eszközölt változásokat a minisztérium, sőt a hatalmi ágak elválasztásából adódó lehetőséggel sem élt, mivel érdemben nem ellenőrizte a hatásköri szabályzatokat, így az igazságszolgáltatáshoz kapcsolódó hatásköreiket is részben megtartották a szolgabírák egyes vármegyékben. A szolgabírák az alsó középszintű közigazgatás általános hatáskörü közigazgatási közegei voltak.

A minisztérium legfóbb célja a járási szervezet átalakítása során annak egységesítése volt, amelyet hatékonyan megvalósított a legfontosabb kérdésekben, így a korábbi partikuláris, rendi igazgatási egységből a polgári kor követelményeinek megfelelő, egységes közigazgatási szervezetté alakulhatott. A legfontosabb centralizációs célt így megvalósította a minisztérium. Ehhez szorosan kapcsolódik a másik cél, hogy kialakították a 
járási szervezet kapcsán az egységes közigazgatási jogi terminológiát, ami még számos jogterületen hiányzott a magyar jogrendszerből. ${ }^{1112}$ A legfontosabb járási hivatalnokok esetében határozottan felléptek emiatt.

A belügyminisztérium ezt az 1870:XLII. tc. által biztosított megerősítési jog által végezhette el, ami a vármegyei operátumok kapcsán illette meg. A minisztérium e jogosultságát igen mértékletesen gyakorolta, mivel általában a törvényi rendelkezésekre hivatkozva a törvényhatósági szervezetek egységesítése érdekében léptek fel. A legtöbb esetben nagy figyelmet fordítottak arra, hogy a törvényhatóságokat önkormányzati jogaik gyakorlásában szükségtelenül ne akadályozzák. Ha a minisztériumi és a törvényhatósági álláspont között nem jött létre véleményazonosság, akkor kevés számú és kevésbé jelentős esetek kivételével érvényesülhetett a vármegyék megoldása. A belügyminiszteri tanácsosok „a túlzásba eső” törvényhatóságokat figyelmeztették, hogy a továbbiakban az államsegélyezés megszűnik, és a vármegyéknek a törvény alapján saját háziadójukból kell fedezniük fenntartásukat. Ez azonban később nem valósult meg. A belügyminisztérium a megerősítés során tehát a vármegyék szervezetalakítási szabadságát tiszteletben tartotta. Alaptalannak tartom emiatt azt a feltételezést, hogy a minisztériumhoz való felterjesztéssel csak látszólagossá vált volna a törvényhatóságok önkormányzati jogosultsága. A minisztériumi állásponttal ellenkező tervezeteket is megerősítették a tanácsosok, ha ahhoz a vármegye közönsége ragaszkodott.

A vármegyék a járási szervezet kapcsán megőrizték a tisztviselők választási jogát, szabadon alakíthatták szervezetüket, a választott vármegyei tisztviselő, az alispán megtartotta utasítási jogkörét a szolgabíróra vonatkozóan, valamint a felelősségre vonásukra is a törvényhatósági bizottság volt jogosult, így inkább decentralizált szervnek tartom a szolgabírói hivatalt. Ennek kapcsán azonban érdemes megjegyezni, hogy a felsoroltak esetében a törvény biztosította a föispán befolyását, így megvoltak a szükséges eszközök arra az esetre, ha a kormányzat a centralizáció erősítését kívánná. A főispán ugyanis a kijelölő választmány útján befolyásolhatta hatékonyan a tisztújítást, élhetett kivételes jogkörével az alispáni utasítással szemben, illetve kezdeményezhette a vármegyei tisztviselő felelősségre vonását. További vizsgálatokra lenne szükség ahhoz, hogy megállapítható legyen, ezek csupán „elkendőzött” biztosítékként szolgáltak, vagy élt is ezekkel a jogosultságaival a főispán. A decentralizációs vonásokat leginkább azonban az erősíthette volna, ha a tisztviselők anyagilag is függetlenek lehettek volna a központi kormányzattól, amelynek normatív alapját meg is teremtette a jogalkotó, azonban sohasem valósulhatott meg.

Az 1870:XLII. tc. alapján kiépített járási szervezet bemutatása kiemelkedő fontosságú, mivel az ország területi beosztásával foglalkozó tudományos munkák a kiegyezést követően csupán a gróf Szapáry Gyula, belügyminiszter vezetésével 1873-ban készített A törvényhatóságok területének szabályozása-és új beosztásáról és A közigazgatási járások száma-és székhelyeinek meghatározása címü törvényjavaslatokat elemezték. ${ }^{113}$ A Szapáry-féle javaslat azonban már nem a rendi, hanem az általam bemutatott alsó középszintü közigazgatási szervezetet kívánta átformálni. E törvényjavaslatok elkészítése során és

1112 Mezey 2011, 101-102.

1113 EREKY 1910, 93-99.; HeNCZ 1973, 125-126. 
a levéltári források tanúsága szerint a vármegyei küldöttségek munkálatai alkalmával is az 1869/1870. év fordulóján készült népszámlálás adatait használták fel. ${ }^{1114}$ Ennek köszönhetően a törvényjavaslatok is új megvilágításban vizsgálhatók.

Munkámban annak bemutatására törekedtem, hogy egy nagy történelmi hagyományokkal bíró közigazgatási egységet és egy tipikusan rendi kori tisztséget hogyan igazítottak a polgári kor követelményeihez. A szolgabírák és azoknak illetékességi területei, a járások fejlődése a magyar történeti alkotmány sajátos keletkezésére és szerves fejlődésére mutatott példát. ${ }^{1115}$ Ennek köszönhetően az alsó középszintű közigazgatás átszervezése a tradícióihoz ragaszkodó magyar társadalom igényeinek is megfelelt. Az igazságszolgáltatási hatáskörök leválasztásával sikerült megteremteni az állami és törvényhatósági közigazgatás alsó középszintű végrehajtási közegeit, amelyek már megfeleltek a polgári állam elvárásainak, így a rendi hagyományokra építő járási szintü közigazgatás 1872-ben megkezdhette működését.

1115 KMETy 1911b, XXVIII. 



\section{FELHASZNÁlT IRODALOM}

ANTAL 2001. = ANTAL Tamás: A közigazgatás és a bíráskodás újjászervezése Debrecenben 1867-ben. In: Radics Kálmán (szerk.): A Hajdú-Bihar Megyei Levéltár Évkönyve. XXVIII. k. Hajdú-Bihar Megyei Levéltár, Debrecen, 2001. 93-119.

ANTAL 2003. = ANTAL Tamás: A bírák nyugdíjazása Magyarországon (1867-1945). Magyar Jog L. évf. 12. sz. 2003. 723-728.

Antal 2005. = AnTAL Tamás: A debreceni népképviseleti közgyülés (1848-1867). Az 1848: XXIII. tc. végrehajtása Debrecenben. Acta Universitatis Szegediensis. Acta Juridica et Politica LXVII. évf. 1. sz. 2005. 3-80.

Antal 2011. = AnTal Tamás: Város és népképviselet. Az 1848:XXIII. tc. és intézményei Debrecenben (1848-1872). Pólay Elemér Alapítvány, Szeged, 2011.

ANTAL 2013a. = ANTAL Tamás: A szabad királyi városokról szóló javaslatok az utolsó rendi országgyülésen és az 1848: XXIII. tc. keletkezése. Acta Universitatis Szegediensis. Acta juridica et politica LXXV. évf. 1. sz. 2013.21-40.

AnTAl 2013b. = ANTAL Tamás: Az országgyűlési képviselők választókerületenkint (1869-1875). In: Ruszoly József: Országgyülési képviselö-választások Magyarországon 1869-1874. 2/3. k. Pólay Elemér Alapítvány, Szeged, 2013. 625-650.

BAKÁCs 1971. = BAKÁCs István János: Hont vármegye Mohács elött. Akadémiai Kiadó, Budapest, 1971.

BALOGH 2015. = BALOGH Judit: A modern bíráskodás kialakulása és fórumai Debrecenben. In: Megyeri-Pálffi Zoltán (szerk.): Jogszolgáltatás Debrecenben. Debreceni Törvényszék, Debrecen, 2015. 19-27.

BALOGH 2017. = BALOGH Judit: Mozaikok a Berettyóújfalui Királyi Járásbíróság történetéből (1872-1949). In: Megyeri-Pálffi Zoltán (szerk.): A jogszolgáltatás története Berettyoúifaluban. Debreceni Törvényszék, Debrecen, 2017.44-55.

BARNA 2006. = BARNA Attila: Kísérlet a magyar vármegyerendszer átalakítására (II. József közigazgatási és büntetőjogi reformjai a magyarországi vármegyékben). In: Mezey Barna, Révész T. Mihály (szerk.): Ünnepi tanulmányok Máthé Gábor 65. születésnapja tiszteletére. Gondolat Kiadó, Budapest, 2006.77-96.

BARTA 2012. = BARTA Attila: A magyar államigazgatás alsó-középszintjének átalakítása 2012-ben. A járások feladataira és szervezetére vonatkozó főbb megállapítások. Kodifikáció és közigazgatás I. évf. 2. sz. 2012. 28-38. 
BATó 2010. = BATÓ Szilvia: „A járásbeli tisztség által megítélt bünügyek”. A szolgabírói szék büntető jellegü bíráskodása a Békési járásban (1843-1847). In: Homoki-Nagy Mária (szerk.): Mezővárosaink jogélete a 18-19. században. Pólay Elemér Alapítvány, Szeged, 2010. 19-47.

BARANY 1975. = BARANY, George: Ungarns Verwaltung: 1848-1918. In: Wandruszka, Adam - Urbanitsch, Peter (szerk.): Die Habsburgermonarchie. II. k. Verlag der Österreichischen Akademie der Wissenschaften, Wien, 1975. 306-468.

BÉLI 1987. = BÉLI Gábor: Vármegyei statutumalkotás a XVI-XVIII. században. In: Ádám Antal (szerk.): Dolgozatok az állam-és jogtudományok köréböl. XVIII. k. Janus Pannonius Tudományegyetem Állam- és Jogtudományi Kara, Pécs, 1987. 69-84.

BÉLI 1988. = BÉLI Gábor: A vármegyei önkormányzat újjáéledése Baranyában a török kiűzése után (1693-1703). In: Szita László (szerk.): Baranyai helytörténetírás 1987/1988. Baranya Megyei Levéltár, Pécs, 1988. 21-50.

BÉLI 2000. = BÉLI Gábor: Zala vármegye Deák Ferenc által megfogalmazott észrevételei a jogügyi munkálatról. In: Molnár András (szerk.): „Javitva változtatni”. Deák Ferenc és Zala megye 1832. évi reformjavaslatai. Zala Megyei Levéltár, Zalaegerszeg, 2000. 285-305.

BÉLI 2005. = BÉLI Gábor: A megye hatóságának és tisztjeinek működése a XIV. század első felében az Ars Notaria formulái alapján. In: Béli Gábor - Kajtár István - Szekeres Róbert (szerk.): Jogtörténeti tanulmányok. VIII. k. PTE ÁJK, Pécs, 2005. 89-107.

BÉLI 2008. = BÉLI Gábor: A nemesek négy birója: a szolgabirók müködésének első korszaka, 1268-1351. Dialóg Campus - PTE ÁJK, Budapest-Pécs, 2008.

BÉLI 2014. = BÉLI Gábor: Bírói gyakorlat a 16. század elejéig. In: Máthé Gábor (szerk.): A magyar jog fejlödésének fél évezrede. Werböczy és a Hármaskönyv 500 esztendö múltán. Nemzeti Közszolgálati Egyetem, Budapest, 2014. 243-268.

BÉLI 2017a. = BÉLI Gábor: A vármegyei nemesi bíráskodás szervezete 1723-ig. Jogtörténeti Szemle XIX. évf. 1-2. sz. 2017.21-31.

BÉLI 2017b. = BÉLI Gábor: Organe der Machtausübung. In: Máthé Gábor (szerk.): Die Entwicklung der Verfassung und des Rechts in Ungarn. Dialóg Campus, Budapest, 2017.93-132.

BENEDEK 1995. = BENEDEK Gábor: Ciszlajtániai tisztviselők a neoabszolutizmuskori Magyarországon. Aetas X. évf. 4. sz. 1995. 60-70.

BENEDEK 2006. = BENEDEK Gábor: A bürokratizáció történetéhez: az 1853-54. évi definitív rendezés személyi következményei. In: Kövér György (szerk.): Zsombékok. Középosztályok és iskoláztatás Magyarországon a 19. század elejétól a 20. század közepéig. Századvég Kiadó, Budapest, 2006. 235-254. 
ВеÖтну 1846. = Веӧтну Zsigmond: Elemi magyar közjog. Emich, Pest, 1846.

Berzeviczy = Berzeviczy Albert: Az absolutismus kora Magyarországon 1849-1865. III. k. Franklin, Budapest, [é.n.].

Bicsok et al 2003. = Bicsok Zoltán - CzIpriáN-Kovács Lóránd - Kozma Csaba - SzéKely Zsolt: Erdély közigazgatás-története. Asociația Ştiințifică Pro Scienția Administrativa, Sepsiszentgyörgy, 2003.

BonCz 1876. = BonCz Ferenc: A magyar közigazgatási törvénytudomány kézikönyve a törvényhozás legújabb állása szerint. I. k. Athenaeum, Budapest, 1876.

BóNIs 1976. = BóNIs György: Bevezetés. In: Döry Ferenc - Bácskai Vera - Bónis György (szerk.): Decreta Regni Hungariae. Gesetze und Verordnungen Ungarns 1301-1457. Akadémiai Kiadó, Budapest, 1976.39-65.

BóNIs 1996. = BóNIs György: A korai és a fejlett feudalizmus korszaka (1000-1526). In: Bónis György - Degré Alajos - Varga Endre: A magyar birósági szervezet és perjog története. Zala Megyei Bíróság - Magyar Jogász Egylet Zala Megyei Szervezete, Zalaegerszeg, 1996. 11-81.

BorsA 1984. = BorSA Iván: Somogy vármegye címereslevele és első pecsétje. In: Kanyar József (szerk.): Somogy megye múltjából. Levéltári évkönyv. XV. k. Somogy Megyeri Levéltár, Kaposvár, 1984. 53-69.

BRAUNEDER 1992. = BRAUNEDER, Wilhelm: Geschichte der Struktur der allgemeinen Verwaltung in Österreich. In: Bundeskanzleramt (szerk.): Die öffentliche Verwaltung in Österreich. Österreichische Staatsdruckerei, Wien, 1992.31-59.

Cepulo 2006. $=$ Cepulo, Dalibor: Building of the modern legal system in Croatia 18481918 in the centre-periphery perspective. In: Giaro, Thomas (szerk.): Modernisierung durch Transfer im 19. und frühen 20. Jahrhundert. Vittorio Klostermann, Frankfurt am Main, 2006. 47-91.

Cepulo 2007. $=$ Cepulo, Dalibor: Modernity in Search of Tradition: The Formation of the Modern Croatian Judiciary 1848-1918. In: Uzelac, Alan - Van Rhee, C.H. (szerk.): Public and Private Justice. Intersentia, Antwerpen-Oxford, 2007. 105-127.

Cepulo 2017. = Cepulo, Dalibor: Organisation und Unabhängigkeit des Gerichtswesens in Kroatien und Slawonien 1848-1918. Beiträge zur Rechtsgeschichte Österreichs VII. évf. 1. sz. 2017. 5-41.

CIEger 2005. = Cieger András: A közigazgatás autonómiájának nézőpontjai 18481918. In: Gergely Jenő (szerk.): Autonómiák Magyarországon 1848-2000. ELTE Történelemtudományok Doktori Iskola - L’Harmattan Kiadó, Budapest, 2005. 25-62. 
Concha 1928. = Concha Győző: A közigazgatási enquete. In: Concha Győző: Hatvan év tudományos mozgalmai között. I. k. Magyar Tudományos Akadémia, Budapest, 1928. 259-317.

C. Tóтн 2005. = C. TóTH Nobert: Bereg megye járásai a középkorban. Szabolcs-Szatmár-Beregi Szemle XL. évf. 2. sz. 2005. 177-186.

C. То́тн 2007. = С. Tóтн Norbert: Lehetőségek és feladatok a középkori járások kutatásában. Századok CXLI. évf. 2. sz. 2007.391-470.

C. То́тн 2008. = С. Tóтн Norbert: Szabolcs megye müködése a Zsigmond-korban. Szabolcs Községért Kulturális Közhasznú Közalapítvány, Nyíregyháza, 2008.

C. Tóтн 2010a. = C. Tóтн Norbert: A világi igazgatás Magyarországon a Zsigmond-korban, különös tekintettel Veszprém megyére. In: Hermann István - Karlinszky Balázs (szerk.): Megyetörténet. Egyház-és igazgatástörténeti tanulmányok a Veszprémi Püspökség 1009. évi adománylevele tiszteletére. Veszprémi Érseki és Főkáptalani Levéltár, Veszprém, 2010.319-344.

C. Tóтн 2010b. = C. Tóтн Norbert: A nemesi megye a középkori Magyarországon. Öt megye példája. Szabolcs-Szatmár-Beregi Szemle XLV. évf. 4. sz. 2010. 405-413.

C. Tóth - Tringli - Draskóczy 2005. = C. TóTH Norbert - Tringli István Draskóczy István: Szabolcs megye hatósága a Zsigmond-korban (1387-1440). Szabolcs-Szatmár-Beregi Szemle XL. évf. 4. sz. 2005. 505-521.

Csemegi 1869a. = Csemegi Károly: A birósági szervezet II. Jogtudományi Szemle I. évf. 3. sz. 1869. 99-103.

Csemegi 1869b. = Csemegi Károly: Birósági szervezet III. Jogtudományi Szemle I. évf. 7. sz. 1869. 283-294.

Csemegi 1904. = Csemegi Károly: Közigazgatás és törvénykezés. In: Edvi Illés Károly-Gyomai Zsigmond (szerk.): Csemegi Károly müvei. I. k. Franklin, Budapest, 1904. 82-101.

Csernus-Lukács 2016. = Csernus-Lukács Szilveszter: Utak a nemzetiségi törvénycikkig. In: Keresztes Gábor (szerk.): Tavaszi Szél 2016/Spring Wind 2016. IV. k. Doktoranduszok Országos Szövetsége, Budapest, 2016.363-374.

Csernus-Lukács 2017. = Csernus-Lukács Szilveszter: Felírási javaslat a nemzetiségi egyenjogúság tárgyában, 1862. Századok CLI. évf. 1. sz. 2017. 189-200.

CsıKy 1888. = Csıky Kálmán: A magyar állam közigazgatási joga . Pallas, Budapest,1888.

Csizmadia 1972. = Csizmadia Andor: A kapitalista állam és a jog 1848-tól 1918-ig. In: Csimadia Andor - Kovács Kálmán - Asztalos László: Magyar állam-és jogtörténet. Tankönyvkiadó, Budapest, 1972.337-450. 
Csizmadia 1976. = Csizmadia Andor: A magyar közigazgatás fejlódése a XVIII. századtól a tanácsrendszer létrejöttéig. Akadémiai Kiadó, Budapest, 1976.

Csorba 1998a. = CsorbA László: Az önkényuralom kora (1849-1867). In: Gergely András (szerk.): 19. századi magyar történelem, 1790-1918. Korona Kiadó, Budapest, 1998. 293-342.

Csorba 1998b. = Csorba László: A dualizmus rendszerének kiépülése és a konszolidált időszak (1867-1890). In: Gergely András (szerk.): 19. századi magyar történelem, 1790-1918. Korona Kiadó, Budapest, 1998. 375-403.

Csorba 2000. = Csorba László: A tizenkilencedikszázad története. Pannonica Kiadó, Budapest, 2000.

Csukovits 1997. = Csukovits Enikő: Sedriahelyek - megyeszékhelyek a középkorban. Történelmi Szemle XXXIX. évf. 3-4. sz. 1997.363-386.

DARóczy 1914. = DARóczy Zoltán: Balassa. Családtörténeti jegyzetek I. évf. 1914. 97-103.

DeÁk 2009. = DeÁk Ágnes: Polgári átalakulás és neoabszolutizmus. Kossuth Kiadó, Budapest, 2009.

DEÁK 2015 = DEÁK Ágnes: A „Bach-Zichi huszár”-ok : Hivatalvállalás a Schmerling-provizórium idején. Századok XLIX. évf. 5. sz. 2015. 1135-1162.

DegRÉ 1980. = DegRé Alajos: A megyei közigazgatás átalakulása a XVIII. század elején. In: Csizmadia Andor (szerk.): Jogtörténeti tanulmányok IV. Közgazdasági és Jogi Könyvkiadó, Budapest, 1980. 59-70.

Degré 1996. = Degré Alajos: A polgári korszak (1861-1944). In: Bónis György - Degré Alajos - Varga Endre: A magyar birósági szervezet és perjog története. Zala Megyei Bíróság - Magyar Jogász Egylet Zala Megyei Szervezete, Zalaegerszeg, 1996. 211-252.

DEGRÉ 2004a. = DegRÉ Alajos: Megyei közgyűlések a XVI-XVII. századi török háborúk korában. In: Mezey Barna (szerk.): Degré Alajos. Válogatott jogtörténeti tanulmányok. Osiris, Budapest, 2004. 163-179.

Degré 2004b. = Degré Alajos: Szavazási rend a megyegyűléseken 1848 elött. In: Mezey Barna (szerk.): Degré Alajos. Válogatott jogtörténeti tanulmányok. Osiris, Budapest, 2004. 180-199.

DegRÉ 2004c. = Degré Alajos: Úriszéki peres eljárás a Dél-Dunántúlon a XVIII-XIX. században. In: Mezey Barna (szerk.): Degré Alajos. Válogatott jogtörténeti tanulmányok. Osiris, Budapest, 2004. 106-129. 
DobsZaY 2015. = DobSZAY Tamás: „A falu jegyzője” Az alsófokú igazgatás személyi feltételeinek kérdése a rendiség utolsó évtizedeiben. Századok CXLIX. évf. 5. sz. 2015. 1055-1067.

Dominkovits 2005. $=$ Dominkovits Péter: A rendi jogok védelmezője - a központi utasítások végrehajtója: a 17. századi magyar vármegye. Századok CXXXIX. évf. 4. sz. 2005. 855-888.

Dominkovits 2010. = Dominkovits Péter: Vármegyei vezetők, közigazgatási feladatok a 17. századi Sopron és Vas vármegyék példáján. In: Hermann István - Karlinszky Balázs (szerk.): Megyetörténet. Egyház-és igazgatástörténeti tanulmányok a Veszprémi Püspökség 1009. évi adománylevele tiszteletére. Veszprémi Érseki és Főkáptalani Levéltár, Veszprém, 2010. 421-444.

Dominkovits-Horváth 2011. = Dominkovits Péter - Horváth Gergely Krisztián: A szolgabíráktól a járási hivatalokig - a járások története Magyarországon a 13. századtól 1983-ig. In: Csite András - Oláh Miklós (szerk.): „Kormányozni lehet ugyan távolról, de igazgatni csak közelröl lehet jól.... Tanulmány a területi igazgatás magyar történelmi hagyományairól, az átalakitásra vonatkozó jelenkori kutatások eredményeinek áttekintése, valamint az európai tapasztalatok bemutatása. Hétfa Elemzö Központ, Budapest, 2011.16-74. (http://hetfa.hu/wp-content/uploads/I_modul. pdf, letöltés ideje: 2021. március 9.)

DRH I. = DöRY Ferenc - BÁcsKaI Vera - BónIs György (szerk.): Decreta Regni Hungariae. Gesetze und Verordnungen Ungarns 1301-1457. Akadémiai Kiadó, Budapest, 1976.

DRMH I. = BAK M. János - BónIs György - SweEneY, James Ross (szerk.): The laws of the medieval Kingdom of Hungary, 1000-1526. I. k. 1000-1301. Charles Schlacks, Bakersfield, 1989.

DRMH II. = BAK M. János - Engel Pál - Sweeney, James Ross (szerk.): The laws of the medieval Kingdom of Hungary, 1000-1526. II. k. 1301-1457. Charles Schlacks, Salt Lake City, [1992].

ECKHART 1931. = ECKHART Ferenc: Jog- és alkotmánytörténet. In: Hóman Bálint (szerk.): A magyar történetírás új útjai. Magyar Szemle Társaság, Budapest, 1931. 269-320.

EDvi 1904. = Edvi Illés Károly: Csemegi Károly élete és kora. In: Edvi Illés Károly-Gyomai Zsigmond (szerk.): Csemegi Károly müvei. I. k. Franklin, Budapest, 1904. VIIXXIII.

EMBer 1946. = EMber Győző: Az újkori magyar közigazgatás története Mohácstól a török kiüzéséig. Budapest Irodalmi Intézet, Budapest, 1946. 
Engel 1989. = Engel Pál: Kamarahaszna-összeirások 1427-böl. Akadémiai Kiadó, Budapest, 1989.

Engel 1998. = Engel Pál: A nemesi társadalom a középkori Ung megyében. MTA Történettudományi Intézete, Budapest, 1998.

Engel 2001. = Engel Pál: Szent István birodalma. A középkori Magyarország története. História - MTA Törttudományi Intézete, Budapest, 2001.

ENGel 2003. = ENGel Pál: Királyi emberek Valkó megyében. In: Csukovits Enikő (szerk.): Honor, vár, ispánság: válogatott tanulmányok. Osiris, Budapest, 2003. 578599.

Engel 2005. = Engel Pál: A királyi hatalom megszilárdítása (1403-1437). In: Engel Pál - Kristó Gyula - Kubinyi András: Magyarország története, 1301-1526. Osiris, Budapest, 2005. 136-153.

ENQUETE $=A$ Tisza Kálmán ministerelnök mint belügyminister által a közigazgatás érdekében 1880. novemberhó 21-dikére egybehivott enquete tárgyalásai. Magyar Királyi Államnyomda, Budapest, 1880.

EREKy 1910. = EREKy István: A magyar helyhatósági önkormányzat. Vármegyék és községek. I. k. Grill Könyvkiadóvállalat, Budapest, 1910.

EREKY 1939. = EREKY István: Az önkormányzat modern rendszerének kialakulása Magyarországon. Budapest Székesföváros Házinyomdája, Budapest, 1939.

Fábián-Mező-Kovacsics 2000. = Fábián Lajos - Mező András - Kovacsics József: Magyarország történeti statisztikai helységnévtára-16. Szabolcs-Szatmár Bereg megye. Központi Statisztikai Hivatal, Budapest, 2000.

Fenete 1914. = Fekete Lajos: A vármegyei tisztikar a XVI-XVII. században. Attila Nyomda, Budapest, 1914.

FÉJA 1939. = FÉJA Tibor: Léva. In: Csatár István - Ölvedi János (szerk.): A visszatért Felvidék adattára. Rákóczi Kiadó, Budapest, 1939.337-343.

FÉsüs 1880. = FÉsüs György: A magyarközigazgatási jog kézikönyve: a jogtanulók s egyéb vizsgálati jelöltek igényeihez alkalmazva. Eggenberger, Budapest, 1880.

FöGLEIN 1924. = FöGLEIN Antal: XVI. századi közigazgatástörténeti adatok Zólyom vármegyéből. Századok LVIII. évf. 1-6. sz. 1924. 466-494.

Föglein-Horváth-Mezey 2001. = Föglein Gizella - Horváth Attila - Mezey Barna: A közigazgatás szervei. In: Mezey Barna (szerk.): Magyar alkotmánytörténet. Osiris, Budapest, 2001.337-362. 
Föglein et al. 2001. = Föglein Gizella - Horváth Attila - Mezey Barna - StiptA István: A közigazgatás szervei. In: Mezey Barna (szerk.): Magyar alkotmánytörténet. Osiris, Budapest, 2003.395-427.

FOKI 2011. = FOKI Ibolya: Riválisok polgárosodása. Források Zalaegerszeg és Nagykanizsa történetéhez, 1867 - 1918. Zala Megyei Levéltár, Zalaegerszeg, 2011.

FrIEDJUNG 1908. = Friedjung, Heinrich: Österreich von 1848 bis 1860. I. k. Stuttgart - J. G. Gotta’ sche Buchhandlung, Berlin, 1908.

GÁBOR 1908. = GÁBOR Gyula: A megyei intézmény alakulása és müködése Nagy Lajos alatt. Grill, Budapest, 1908.

GeCSÉNYi 1988. = GeCsÉNYI Lajos: Győr megye közigazgatása és tisztikara a XVII. században. Levéltári szemle XXXVIII. évf. 3. sz. 1988. 14-34.

Gergely-SzÁsz 1978. = Gergely András - SzÁsz Zoltán: Kiegyezés után. Gondolat, Budapest, 1978.

Gergely-Veliky 1985. = Gergely András - Veliky János: A 48-as áramlatok sajtója. In: Kosáry Domokos - Németh G. Béla (szerk.): A magyar sajtó története. II/2. k. Akadémiai Kiadó, Budapest, 1985. 112-131.

GERICS 1969. = GERICS József: Árpád-kori jogintézmények és terminológia törvényhozásunk egyik keltezetlen emlékében. Századok CIII. évf. 4. sz. 1969. 611-640.

GYURIKovits 1841. = GYuRIKovits György: A' Megyei tisztviselők, föképen Szolga Birák' választása hajdankorban. Tudományos Gyüjtemény XXV. évf. 7. sz. 1841. 52-58.

HAJDU 1982. = HAJDU Lajos: II. Józsefigazgatási reformjai Magyarországon. Akadémiai Kiadó, Budapest, 1982.

HAJDÚ 1993. = HAJDÚ Zoltán: A magyar megyerendszer történeti, területi fejlődésének sajátosságai (I.). Comitatus III. évf. 1. sz. 1993.

HajDú 2001. = HajDú Zoltán: Magyarország közigazgatási folldrajza. Dialóg Campus, Budapest-Pécs, 2001.

Hajnik 1899. = Hajnik Imre: A magyar birósági szervezet és perjog az Arpád-és vegyes-házi királyok alatt. Magyar Tudományos Akadémia, Budapest, 1899.

Havassy 1986. = Havassy Péter: Heves megye középkori tisztségviselöi. Dobó Vármúzeum, Eger, 1986.

Hellebronth 1914. = ifj. Hellebronth Kálmán: Torkos (ócsai). Családtörténeti Jegyzetek I. évf. 1914. 201-214.

HelyséGnÉvtÁr = A Magyar Korona országainak helységnévtára. Országos Magyar Királyi Statistikai Hivatal, Budapest, 1873. 
Hegedüs 1932. = Hegedüs Kálmán: A törvényhozó összeférhetetlensége. Magyar Szemle XIV. évf. 4. sz. 1932.310-320.

HegYi 2001. = Hegyi Klára: Az oszmán hatalom berendezkedése és működése. In: Kosáry Domokos (szerk.): Pest megye monográfiája. Pest Megye Monográfia Közalapítvány, Budapest, 2001.255-328.

HeKa 2004a. = HeKa László: Horvát alkotmány-és jogtörténet. II. k. JATEPress, Szeged, 2004.

HeKa 2004b. = HeKa László: A magyar-horvát államközösség alkotmány-ésjogtörténete. Bába, Szeged, 2004.

Hellbling 1975. = Hellbling, Ernst: Die Landesverwaltung in Cisleithanien. In: Wandruszka, Adam - Urbanitsch, Peter (szerk.): Die Habsburgermonarchie 1848 1918. Verwaltung und Rechtswesen. II. k. Verlag der Österreichischen Akademie der Wissenschaften, Wien, 1975. 190-305.

Hencz 1973. = Hencz Aurél: Területrendezési törekvések Magyarországon. Közgazdasági és Jogi Kiadó, Budapest, 1973.

HerCzegh 1871. = HerCzegh Mihály: Magyar polgári törvénykezési rendtartás 1868: 54 t. cz. folytonos tekintettel a vonatkozó felsöbb rendeletekre, a Magyr. Kir. Curia Semmitöszékének elvi jelentöségü határozataira, nem különben a Magyar-és Erdélyországi korábbi törvények és törvényszéki gyakorlatra. Heckenast, Pest, 1871.

Holu в 1917. = Holub József: Szolgabíró. Magyar Nyelv XIII. évf., 7-8. sz. 1917. 238-239.

Holub 1929. = Holub József: Zala megye története a középkorban. I. k., Zala megye közönsége, [Pécs], 1929.

Holuв 1938. = Holuв József: A királyi vármegyék eredete. In: Serédi Jusztinián (szerk.): Emlékkönyv Szent István király balálának kilencszázadik évfordulóján. II. k. Magyar Tudományos Akadémia, Budapest, 1938.71-106.

Homoki-Nagy 2004. = Homoki-NaGy Mária: Az 1795. évi magánjogi tervezetek. JATEPress, Szeged, 2004.

Homoki-NAGY 2019. = HomokI-NAGY Mária: A magyar gyámsági jog a neoabszolutizmus korában. Acta Universitatis Szegediensis. Forum. Acta Juridica et Politica IX. évf. 1. sz. 2019. 45-55.

HómAN-Török 1909. = Hóman Bálint - Török Pál: Szolgabiró. Századok XLIII. évf. 4. sz. 1909. 320.

IvÁNYI 1917. = IVÁNYI Béla: Nyelvtörténeti adatok. Magyar Nyelv XIII. évf., 7-8. sz. 1917.251-259. 
IuszTin 2013. = IuszTin, Zoltán: The Noble Judges in Timis County (14th-15th Centuries). Transylvanian Review XXII. évf. 4. sz. 2013.253-264.

JAKAB 2011. = JаKAB András: A bírói jogértelmezés az Alaptörvény tükrében. Jogesetek Magyarázata II. évf. 4. sz. 2011. 86-94.

KÁDAS 2014a. = KÁDAS István: Északkelet-Magyarország szolgabírói a Zsigmond-korban (Archontológia). In: Belucz Mónika - Gál Judit - Kádas István - Tarján Eszter (szerk.): Magister historiae: válogatott tanulmányok a 2012-ben és 2013-ban megrendezett középkorral foglalkozó, mesterszakos hallgatói konferenciák elöadásaiból. ELTE BTK Történelemtudományok Doktori Iskola, Budapest, 2014. 101-127.

KÁDAS 2014b. = KÁDAS István: Az Abaúj megyei szolgabírói társadalom a Zsigmond-korban. Korall LVII. évf. 15. sz. 2014. 110-132.

KÁDAS 2015a. = KÁDAS István: Szolgabírói társadalom Sáros megyében a 15. század elején. In: Kántor Balázs - Mihalik Béla - Zarnóczki Áron (szerk.): Tanulmányok Badacsonyból III. A Fiatal Levéltárosok Egyesületének konferenciája. Fiatal Levéltárosok Egyesülete, Budapest, 2015.9-33.

KÁDAS 2015b. = KÁDAS István: Megyei emberek az északkelet-magyarországi megyei oklevelekben. In: Gál Judit - Kádas István - Rózsa Márton - Tarján Eszter (szerk.): Micae mediaevales IV. Fiatal történészek dolgozatai a középkori Magyarországról és Európáról. ELTE BTK Történelemtudományok Doktori Iskola, Budapest, 2015. $107-122$.

KÁDAS 2015c. = KÁDAS István: Sárvári László és az 1444. évi X. törvénycikk. In: Ternovácz Bálint (szerk.): Opuscula Historica I. Történeti tanulmányok a XIV.és XV. Eötvös Konferenciáról. ELTE Eötvös József Collegium, Budapest, 2015.45-58.

KÁDAS 2016. = KÁDAs István: Sárosi „reform” Miklós fia Miklós ispánsága idején (13741380)? In: Fábián Laura - Gál Judit - Haraszti Szabó Péter - Uhrin Dorottya (szerk.): Micae mediaevales V. Fiatal történészek dolgozatai a középkori Magyarországról és Európáról. ELTE BTK Történelemtudományok Doktori Iskola, Budapest, 2016. $127-144$.

KÁDAS 2017. = KÁDAs István: Cum sigillo nostro. A késő középkori Sáros megye pecséthasználata. Történelmi Szemle LIX. évf. 4. sz. 2017. 637-653.

KÁDAs 2020. = KÁDAs István: A megye emberei. A szolgabirói hivatal és viselöi Északkelet-Magyarországon (1329-1545). Bölcsészettudományi Kutatóközpont Történettudományi Intézet, Budapest, 2020.

KAJTÁR 1992. = KAJTÁR István: Magyar városi önkormányzatok (1848-1918). Akadémiai Kiadó, Budapest, 1992. 
KAJTÁR 2004. = KAJTÁR István: A polgári modernizáció közigazgatási autonómiáinak jogtörténeti keretei. In: Gergely Jenő (szerk.): Autonómiák Magyarországon 18481998. ELTE BTK Új- és Jelenkori Magyar Történeti Tanszék, Budapest, 2004. 25-39.

Kassay 1865. = KAsSAY Adolf: A szolgabirák és megyei esküdtek hatásköre és teendöi. Stolp Károly, Pest, 1865.

Kecskeméthy 1867. = Kecskeméthy Aurél: Parlamenti alkotmány és vármegyei reactio. Ráth Mór, Pest, 1867.

Kegyes Tanitórendiek 1864. = A Kegyes Tanitórendiek Pesti Nagy Gymnasiumába járó ifjuságnak érdemszerénti osztályozása 1864/5-iki tanév második felében. Emich Gusztáv, Pest, 1865.

Kelemen 1970. = Kelemen Ferenc: Makó igazgatásának történeti formái. [s.n.], Makó, 1970.

KeLETI 1886. $=$ KeLETi Ferencz: Az államszolgálat jogi természete és a rendszeres államszolgálati pragmatika elvei, különös tekintettel hazánk viszonyaira és a nevezetesebb európai államok e tárgyra vonatkozó intézkedései. Singer és Wolfner, Budapest, 1886.

Kempelen 1912. = Kempelen Béla: Magyar nemes családok. III. k. Grill, Budapest, 1912.

Kempelen 1932. = Kempelen Béla: Magyar nemes családok. XI. k. Grill, Budapest, 1932.

KÉRÉSZY 1942. = KÉRÉSZY Zoltán: Községi közigazgatásunk alaptörvényének (1871:XVIII. t.-c.) előzményei. In: Eckhart Ferenc - Degré Alajos (szerk.): Emlékkönyv Dr. Viski Illés József ny. r. egyetemi tanár tanári müködésének negyvenedik évfordulójára. Stephaneum, Budapest, 1942.247-300.

KisteleKi 2018. = KisteleKi Károly: Erdély és Magyarország első egyesülése: az 1848-as uniós törvény. In: Veress Emőd (szerk.): Erdély jogtörténete. Forum Iuris, Kolozsvár, 2018. 282-286.

KMety 1905. = KMety Károly: A magyar közigazgatási jog kézikönyve. Politzer-féle Könyvkiadóvállalat, Budapest, 1905.

KMETY 1911a. = KMETY Károly: A magyar közigazgatási és pénzügyi jog kézikönyve. I. k. Grill, Budapest, 1911.

Kмету 1911b. = KMety Károly: A magyar közjog tankönyve. Grill, Budapest, 1911.

KormÁnyprogram = Kiss Péter (szerk.): Magyar kormányprogramok 1867-2002. I. k. Magyar Hivatalos Közlönykiadó, Budapest, 2004.

Kor 2013. = KoI Gyula: Évszázadok mezsgyéjén: négy magyar közigazgatás-tudós útkeresése és életpéldája. Nemzeti Közszolgálati és Tankönyv Kiadó, Budapest, 2013. 
Komoróczy 1903. = Komoróczy Miklós: Rozsnyó. In: Borovszky Samu (szerk.): Magyarország vármegyéi és városai. Gömör-Kishont vármegye. Apollo Irodalmi Társaság, Budapest, 1903. 121-129.

Koncz 2018. = KonCz Ibolya Katalin: Exekutive und Judikative Gewaltenteilung aufgrund des Act. IV. des jahres 1869 - Erfolg oder Misserfolg?. In: Homoki-Nagy Mária - Varga Norbert (szerk.): Codification achievments and failures in the $19^{\text {th }}-20^{\text {th }}$ Century. University of Szeged Department of Hungarian Legal History, Szeged, 2018.77-82.

KRISTÓ 1988. = KRIsTó Gyula: A vármegyék kialakulása Magyarországon. Magvető, Budapest, 1988.

LADIK 1932. = LADIK Gusztáv: Közigazgatásunk fejlódése 1867. óta. Fővárosi Könyvnyomda, Budapest, 1932.

LEHNER 1992. = LEHNER, Oskar: Österreichische Verfassungs- und Verwaltungsgeschichte mit Grundzügen der Wirtschafts- und Sozialgeschichte. Universitätsverlag Rudolf Trauner, Linz, 1992.

LEHNER 1995. = LEHNER, Oskar: Von der Kabinettsjustiz zur Unabhängigkeit der Richter - Die Stellung der österreichischen Justiz im 18. und 19. Jahrhundert. In: Weinzierl, Erika - Rathkolb, Oliver - Ardelt, Rudolf G. - Mattl, Siegfried: Justiz und Zeitgeschichte. II. k. Verlag Jugend \& Volk, Wien, 1995. 5-29.

LeHOCZKy 1907. = LeHOCzKy Tivadar: Munkács város új monográfiája. Grünstein Mór, Munkács, 1907.

Lengyel 1965. = Lengyel Alfréd: Az autonom nemesi Győr megye kialakulása és működése 1526-ig. In: Uzsoki András (szerk.): Arrabona. A Györi Múzeum Évkönyve. Győri Xántus János Múzeum, Győr, 1965.

LikTOR 2016. = LikToR Zoltán Attila: A nemesi vármegye felépítése és a végrehajtásban játszott szerepe, különös tekintettel a Jagelló-korra. In: Pogácsás Anett - Szilágyi Pál - Láncos Petra Lea - Kovács Krisztián (szerk.): „De lege ferenda”. Válogatott tanulmányok joghallgatók tollából. Pázmány Press, Budapest, 2016.331-346.

LiKTOR 2017. = LIKTOR Zoltán Attila: A nemesi vármegye az igazságszolgáltatás tükrében, különös tekintettel a Hunyadi- és a Jagelló-korra. Iustum Aequum Salutare XIII. évf. 1. sz. 2017.211-223.

NÉVtÁr = Magyarország tiszti czim-és névtára 1873. Athenaeum, Budapest, 1874 .

Magyar Királyi Tudomány-Egyetem 1870. = A Magyar Királyi Tudomány-Egyetem személyzete. MDCCCLXIX-LXX. Magyar Királyi Egyetemi Nyomda, Buda, 1870 . 
MAgYAR UjSÁG RÖPIRATA = A Magyar Ujság röpirata. A megyék és városok rendezéséröl, tekintettel Tisza Kálmán, Kovách László és Szentkirályi Mór e tárgyu röpirataira. Noséda Nyomda, Pest, 1868.

Magyary 1942. = Magyary Zoltán: Magyar közigazgatás. Királyi Magyar Egyetemi Nyomda, Budapest, 1942.

MÁlyusz 1957. = MÁLYUSz Elemér: A magyar rendi állam Hunyadi korában. I. rész. Századok XCI. évf. 1-4. sz. 1957. 46-123.

Mályusz 1984. = MÁLyusz Elemér: Zsigmond király uralma Magyarországon, 13871437. Gondolat, [Budapest], 1984.

MARJANuCz 2013. = MARJANuCz László: A járás a magyar történelemben. In: Homoki-Nagy Mária (szerk.): Ünnepi kötet Dr. Blazovich László egyetemi tanár 70. születésnapjára. SZTE-ÁJTK, Szeged, 2013. (Acta Universitatis Szegediensis. Acta juridica et politica) $441-454$.

Márkus 1912. = Márkus Dezső: Ungarisches Verwaltungsrecht . Mohr, Tübingen, 1912.

MáTHÉ 1982. = MÁTHÉ Gábor: A magyar burzsoá igazságszolgáltatási szervezet kialakulása, 1867-1875. Akadémiai Kiadó, Budapest, 1982.

MáTHÉ 1990. = MÁTHÉ Gábor: Az államszervezet felépítésének történeti modellje a magyar polgári államszervezet. In: Csimadia Andor - Máthé Gábor - Nagy Endre: Magyar közigazgatástörténet. Államigazgatási Főiskola, Budapest, 1990. Kézirat. $51-83$.

MÁTHÉ 2006. = MÁTHÉ Gábor: Polgári kori közigazgatásunk történeti jellemzői. In: Imre Miklós - Lamm Vanda - Máthé Gábor (szerk.): Közjogi tanulmányok Lörincz Lajos 70. születésnapja tiszteletére. [Aula], [Budapest], 2006. 262-267.

MÁTHÉ 2013. = MÁTHÉ Gábor: A magyar békebírói intézmény. In: Máthé Gábor Révész T. Mihály (szerk.): Állam-, egyház-, jogtörténeti magyarázatok. Ünnepi tanulmányok Rácz Lajos tiszteletére 65. születésnapja alkalmából. Multiszolg, [Vác], 2013. 85-97.

MÁTHÉ 2015. = Máthé Gábor: Der ungarische Rechtstaat in der Zeit der Doppelmonarchie. In: Máthé Gabor - Mezey Barna (szerk.): Kroatisch-Ungarische Öffentlich-Rechtliche Verhältnisse zur Zeit der Doppelmonarchie. Eötvös University Press, Budapest, 2015. 105-185.

MÁTHÉ 2017. = Máthé Gábor: Das institutionelle System des ungarischen Rechtsstaates und die Doppelmonarchie. In: Máthé Gábor (szerk.): Die Entwicklung der Verfassung und des Rechts in Ungarn. Dialóg Campus, Budapest, 2017.403-450. 
Megyeri-PÁlffi 2015. = Megyeri-PÁlffi Zoltán: Igazságügyi építkezések Debrecenben. In: Megyeri-Pálffi Zoltán (szerk.): Jogszolgáltatás Debrecenben. Debreceni Törvényszék, Debrecen, 2015.43-57.

Megyer-PÁlffi 2017. = Megyeri-PÁlffi Zoltán: Új bíróságok, új épületek?. In: Kis Norbert - Peres Zsuzsanna (szerk.): Ünnepi tanulmányok Máthé Gábor oktatói pályafutásának 50. jubileumára. Dialóg Campus, Budapest, 2017. 267-274.

MegYeri-PÁlfFi 2018. = MegYeri-PÁlffi Zoltán: A Hajdúböszörményi Járásbíróság megszervezésének és elhelyezésének története. In: Megyeri-Pálffi Zoltán (szerk.): $A$ jogszolgáltatás története Hajdúböszörményben. Debreceni Törvényszék, Debrecen, 2018. 59-77.

Mezey 1996. = Mezey Barna: A nemesi képviselettől a polgári képviseletig (A képviselet és a képviselői jogállás tartalmának megváltozása 1848/49-ben). In: Soltész István (szerk.): A képviselők jogállása (1. rész). Parlamenti Módsztertani Iroda, Budapest, 1996. 241-255.

Mezey 2004. = Mezey Barna: Államosítás és autonómia. Centralizáció és önkormányzatiság a XIX. század második felében. In: Gergely Jenő (szerk.): Autonómiák Magyarországon 1848-1998. ELTE BTK Új- és Jelenkori Magyar Történeti Tanszék, Budapest, 2004. 13-24.

Mezey 2011. = Mezey Barna: A bírói szervezet átalakítása és a büntetés-végrehajtási intézetek a 19. században. In: Homoki-Nagy Mária (szerk.): Konferencia a birói hatalomról és az állampolgárságról. Szegedi Egyetemi Kiadó - Juhász Gyula Felsőoktatási Kiadó, Szeged, 2011.101-110.

Mezey 2018. = Mezey Barna: Helyi igazgatási modellek Erdélyben. In: Veress Emőd (szerk.): Erdély jogtörténete. Forum Iuris, Kolozsvár, 2018. 131-149.

Meznerics 1933. = Meznerics Iván: A megyei büntetö igazságszolgáltatás a XVI-XIX. században. Sárkány Nyomda, Budapest, 1933.

MolnÁr 2000. = MolnÁr András (szerk.): „Javitva változtatni”. Deák Ferenc és Zala megye 1832. évi reformjavaslatai. Zala Megyei Levéltár, Zalaegerszeg, 2000.

NAGY 1899. = NAGy Ernő: Centralisatio. In: Márkus Dezső (szerk.): Magyar jogi lexikon. II. k. Pallas Irodalmi és Nyomdai Részvénytársaság, Budapest, 1899. 513-516.

NeMZeTI KALENDÁRIOM 1855. = Közhasznu és mulattató nemzeti vagy hazai kalendáriom, magyarországi és erdélyi katholikusok', evangelikusok, ó bitüek és zsidók számára. Krisztus urunk születése után 1855dik közönséges azaz 365 napból álló esztendöre. Trattner és Károlyi, Pest, 1855. 
NemZeti KALENDÁRIOM 1856. = Közhasznu és mulattató nemzeti vagy hazai kalendáriom, magyarországi és erdélyi katholikusok', evangelikusok' és ó hitüek számára. Krisztus urunk születése után 1856dik szökö azaz 366 napból álló esztendöre. Trattner és Károlyi, Pest, 1856.

NeMzeti KALENDÁRIOM 1858. = Közhasznu és mulattató nemzeti vagy hazai kalendáriom, magyarországi és erdélyi katholikusok, evangelikusok, ó hitüek és zsidók számára. Krisztus urunk születése után 1858dik közönséges azaz 365 napból álló esztendöre. Trattner és Károlyi Könyvnyomda, Pest, 1858.

Nemzeti KALENDÁRIOM 1860. = Közhasznu és mulattató nemzeti vagy hazai kalendáriom, magyarországi és erdélyi katholikusok, evangelikusok, ó hitüek és zsidók számára. Krisztus urunk születése után 1860 dik szökö azaz 366 napból álló esztendöre. Trattner és Károlyi, Pest, 1860.

Neumann $2005=$ Neumann Tibor: Választott nemesi esküdtek Nyitra megyében . Az 1486. évi 8. tc. végrehajtása. Századok CXXXIX. évf. 2. sz. 2005. 261-289.

Neumann 2009. = Neumann Tibor: Nyitra megye hegyentúli járásának kamarahaszna-összeírása 1452-ből. In: Neumann Tibor - Rácz György (szerk.): Honoris causa. Tanulmányok Engel Pál tiszteletére. MTA Történettudományi Intézete, Budapest, 2009. 183-234.

NovÁk 2003. = Novák Veronika: Nyitra, Bars és Abaúj vármegyék tisztségviselői és oklevélkiadásuk 1526-ig. Szabolcs-Szatmár-Beregi Levéltári Évkönyv XVI. évf. 2003. 29-55.

Nyakas 1980. = NyaKas Miklós: Hajdú vármegye megszervezése 1876/77-ben. In: Gazdag István (szerk.): Hajdú-Bihar Megyei Levéltár évkönyve. VII. k. Hajdú-Bihar Megyei Levéltár, Debrecen, 1980. 5-17.

Nyáry 1840. = Nyáry Pál (szerk.): Javallat Pest megye’ közigazgatási rendszere iránt. Trattner-Károlyi, Pest, 1840.

Olechowski 2014. = Olechowski, Thomas: Das Kaisertum Österreich 18481867. In: Arbeitsgemeinschaft Österreichische Rechtsgeschichte: Rechts- und Verfassungsgeschichte. facultas.wuv, Wien, 2014. 190-205.

OrSZÁGgyỦLÉSI ALMANACH 1905. = Fabro Henrik - Ujlaki József (szerk.): Sturm-féle országgyülési almanach 1905-1910. Pesti Lloyd, Budapest, 1905.

Osváth 1911. = Osváth Gyula: A vármegyei autonómia és a vármegyei tisztviselök 1848 elött. Politzer, Budapest, 1911.

Osváth 1912. = Osvát Gyula: A magyar vármegyei szervezet 1608-ig. Lévai, Rimaszombat, 1912. 
Osváth 1914. = OsvátH Gyula: A magyar vármegyei szervezet 1608-ig. Franklin, Budapest, 1914.

Palugyay 1844a. = Palugyay Imre: Megye-rendszer hajdan és most. Megye-alkotmány. I. k. Heckenast, Pest, 1844.

Palugyay 1844b. = Palugyay Imre: Megye-rendszer hajdan és most. Megye-hivatalok . II. k. Heckenast, Pest, 1844.

PAP 2014. = PAP József: A választójog és a választókerületi beosztás problematikája Erdélyben (1848-1877). In: Pap József: Tanulmányok a dualizmus kori magyar parlamentarizmus történetébőll. Akadémiai Kiadó - EKF Líceum Kiadó, Budapest, 2014. $239-269$.

PAP 2016. = PAP József: Rokonok. Családi kapcsolati hálózatok a dualizmus kori Heves vármegye föszolgabírói karában. In: Pap József - Tóth Árpád (szerk.): Vidéki élet és vidéki társadalom Magyarországon. Hajnal István Kör - Társadalomtörténeti Egyesület, Budapest, 2016. 468-485.

PAP 2017. = PAP József: Szolgabírók és föszolgabírók a dualizmus kori Heves vármegyében. Agria. Annales Musei Agriensis L. évf. 2017. 463-473.

PAPP 2012a. = PAPp László: Az önkormányzatiság vázlatos áttekintése, különös tekintettel a hosszú 19. század alkotmányos megoldásaira. De Iurisprudentia et Iure Publico VI. évf. 1-2. sz. 2012.97-107.

PAPp 2012b. = PApp László: The Concept of Autonomous Local Governments and their Different Forms of Appearances in the Traditions of our National Public Law. Journal on European History of Law III. évf. 1. sz. 2012. 62-65.

PAPP 2014. = PAPP László: A rendes bírósági szervezet változásai Magyarországon 18491861 között. Acta Universitatis Szegediensis. Forum. Acta Juridica et Politica IV. évf. 1. sz. 2014. 157-167.

PAPP 2017. = PAPP László: Különbíróságok szerepe és rendeltetése a modern igazságszolgáltatási rendszerekben. Acta Universitatis Szegediensis. Forum. Acta Juridica et Politica VII. évf. 1. sz. 2017. 69-81.

Pecze 1966. = Pecze Ferenc: A magyar parlamenti összeférhetetlenségi jog (inkompatibilitás) szabályozása a századforduló előtt (1861-1901). In: Csizmadia Andor (szerk.): Jogtörténeti tanulmányok I. Közgazdasági és Jogi Könyvkiadó, Budapest, 1966. 29-54.

Perger 1831. = Perger János: A' magyar és hazája régenten . Trattner, Pest, 1831.

Pokoly 1901. = Pokoly József: A vármegyei intézmény története 1301-1886. In: Tagányi Károly - Réthy László - Pokoly József: Szolnok-Doboka vármegye monográphiája. I. k. Szolnok-Doboka vármegye közönsége, Deés, 1901.253-537. 
PUKy 1828. = Puky Károly: Politikai igazgatás, avagy A' magyar országi tekintetes nemes vármegyék' politikai szerkeztetéseknek és igazgatások módjainak, úgy nem külömben azon nemes megyék, melly politikai igazgató székek által, és miképpen való kormányoztatásoknak rövid leirása. Petrózai Trattner J. M. és Károlyi Istvánnál, Pest, 1828.

RÁCz 2007. = RÁcz Lajos: Feudális korszak. In: Máthé Gábor (szerk.): Magyar alkotmány-és közigazgatástörténet. HVG-ORAC, Budapest, 2007. 15-290.

Rajkay Friebeisz 1861. = R.F.I. [RAJKay Friebeisz István]: Megyei alkotmányos mozgalmak 1860. oct. 20-tól, 1861. april 2-ig, mint a Nemzetgyülés megnyitása napjáig. Müller, Pest, 1861.

RÉCSI 1854. = RÉCSI Emil: Közigazgatási törvénytudomány kézikönyve, az ausztriai birodalmi törvényhozás jelen állása szerint különös tekintettel Magyarországra. I. k. Heckenast, Pest, 1854.

RÉCSI 1861. = RÉCsI Emil: Magyarország közjoga a mint 1848-igs 1848-ban fenállott . Pfeiffer Ferdinánd, Buda-Pest, 1861.

ReISZIg 1912. = Reiszig Ede: A vármegye nemes családai. In: Borovszky Samu (szerk.): Torontál vármegye. Országos Monografia Társaság, Budapest, 1912. 519-554.

Reiter-Zatloukal 2014. = ReIter-Zatloukal, Ilse: Die Österreichisch-Ungarische Monarchie 1867-1918. In: Arbeitsgemeinschaft Österreichische Rechtsgeschichte: Rechts-und Verfassungsgeschichte. facultas.wuv, Wien, 2014. 205-228.

Ruszoly 1982. = Ruszoly József: A népképviseleti önkormányzat szegedi történetéhez (1848-1871). Acta Universitatis Szegediensis. Acta Juridica et Politica XXXIX. évf. 4. sz. 1982. 1-65.

Ruszoly 1986. = Ruszoly József: A hazai választási statisztika kezdetei (1848-1869). In: Tóth Károly (szerk.): Studia in honorem Roberti Horváth septuagenarii. JATE, Szeged, 1986. 217-237.

Ruszoly 1996. = Ruszoly József: Az országgyűlési népképviselet bevezetése Magyarországon (Az 1848: V. tc. létrejötte). In: Fazekas Csaba (szerk.): Társadalomtörténeti tanulmányok. Bíbor Kiadó, Miskolc, 1996. 277-299.

Ruszoly 2004. = Ruszoly József: Szeged szabad királyi város törvényhatósága, 18721944. Csongrád Megyei Levéltár, Szeged, 2004.

Ruszoly 2009. = Ruszoly József: Beiträge zur neueren Verfassungsgeschichte. Gondolat, Budapest, 2009.

Ruszoly 2013. = Ruszoly József: Országgyülési képviselö-választások Magyarországon 1869-1874.2/3. k. Pólay Elemér Alapítvány, Szeged, 2013. 
RÜsz-FogARASI 2009. = RÜsz-FOGARASI Enikő: Kolozs vármegye szolgabírái a középkorban. Turul LXXXII. évf. 1. sz. 2009. 1-12.

SALlaI 2020a. = SALlaI Balázs: A törvényhatósági tisztviselők fegyelmi eljárásának lefolytatására jogosult szervek de lege lata et ferenda a XIX. században. In: Karlovitz János Tibor (szerk.): Jogok és lebetöségek a társadalomban. International Research Institute, Komárno, 2020. 57-73.

SAllai 2020b. = SALlaI Balázs: A közszolgálati fegyelmi felelősség kezdetei a polgári kori Magyarországon. Régiókutatás Szemle V. évf. 1. sz. 2020. 59-66.

Sallai 2020c. = SAllai Balázs: Törvény egy Straf-colonia részére? Az 1876. évi VII. törvénycikk a jogalkotás és a debreceni joggyakorlat tükrében. In: Szücs Lászlóné Siska Katalin - Talabos Dávidné Lukács Nikolett (szerk.): A jog tudománya, a mindennapok joga IV. k. Debreceni Egyetem Állam- és Jogtudományi Kar, Debrecen, 2020. 249-262.

SALlaI 2020d. = SALlaI Balázs: Adalékok a törvényhatósági tisztviselők büntetőjogi és fegyelmi felelősségéhez a polgári kori szabályozásban. A büntetjogi és a fegyelmi felelősség elhatárolási kérdései. In: Szücs Lászlóné Siska Katalin - Talabos Dávidné Lukács Nikolett (szerk.): Tudományos Diákest Tanulmánykötet VII. k. Debreceni Egyetem Állam- és Jogtudományi Kar, Debrecen, 2020. 133-147.

SARLÓs 1976. = SARLós Béla: Közigazgatás és hatalompolitika a dualizmus rendszerében . Akadémiai Kiadó, Budapest, 1976.

SASHegyi 1965. = SASHEgYi Oszkár: Az abszolutizmuskori levéltár. Akadémiai Kiadó, Budapest, 1965.

SASHegyi 1981. = SASHegyi Oszkár: A neoabszolutizmus rendszere 1849-1867. In: Pölöskei Ferenc - Ránki György (szerk.): A magyarországi polgári államrendszerek. Tankönyvkiadó, Budapest, 1981.81-139.

SIKeT 2020. = SikeT Judit: $A$ helyi önkormányzatok közigazgatási autonómiája Magyarországon. Iurisperitus Kiadó, Szeged, 2020.

Somogyi 1981. = Somogyi Éva: Abszolutizmus és kiegyezés 1849-1867. Gondolat, Budapest, 1981.

STIPTA 1976. = STIPTA István: A törvényhatóságok egységesítésére irányuló reformmunkálatok 1873-1874-ben. Acta Iuvenum. Sectio Juridica et Politica, Series Nova, Tomus I. 1976. 111-150.

STIPTA 1978. = STIPTA István: Einige Fragen der Umorganisierung des Hajdu-Bezirkes zu einem Komitat, 1848-1876. In: Kovács Kálmán - Máthé Gábor (szerk.): Entwicklung der städtischen und regionalen Verwaltung in den letzten 100 Jahren in Mittel-und Osteuropa. ELTE Állam- és Jogtudományi Kar, Budapest, 1978. 291-317. 
STIPTA 1985. = STIPTA István: Vármegyei reformkoncepciók az 1870. XLII. tc. képviselőházi vitájában. Állam és igazgatás XXXV. évf. 10. sz. 1985. 910-917.

STIPTA 1992a. $=$ STIPTA István: Az első polgári kori vármegyetörvény (1848:XVI. tc). Acta Universitatis Szegediensis. Acta Juridica et Politica XLII. évf. 5. sz. 1992. 3-34.

STIPTA 1992b. = STIPTA István: Intézménytörténeti adalékok az 1870:XLII. tc. végrehajtásához. In: Tóth Károly (szerk.): Emlékkönyv Dr. Cséka Ervin egyetemi tanár születésének 70. és oktatói munkásságának 25. évfordulójára. JATE, Szeged, 1992. 481-494.

STIPTA 1995a. = STIPTA István: A föispáni hatáskör törvényi szabályozása $(1870,1886)$. In: Máthé Gábor - Zlinszky János (szerk.): Degré Alajos emlékkönyv. UNIÓ Lap- és Könyvkiadó, Budapest, 1995. 299-312.

STIPTA 1995b. = STIPTA István: Törekvések a vármegyék polgári átalakitására. Osiris, Budapest, 1995.

STIPTA 1998a. = STIPTA István: A magyar birósági rendszer története. Multiplex Media - Debrecen U. P., Debrecen, 1998.

STIPTA 1998b. = STIPTA István: Parlamenti viták a területi önkormányzatról (18701886). In: Mezey Barna (szerk.): Hatalommegosztás és jogállamiság. Osiris, Budapest, 1998. 77-93.

STIPTA 1998c. = STIPTA István: Bestrebungen zur Veränderung der ständischen Komitatsverfassung im ungarischen Vormärz. In: Péter Márta Orsolya - Szabó Béla (szerk.): A bonis bona discere: Festgabe für János Zlinszky zum 70. Geburtstag. Bíbor Verlag, Miskolc, 1998. 473-484.

STIPTA 2005a. = STIPTA István: Die vertikale Gewaltentrennung (Verfassungs- und rechtsgeschichtliche Studien). Gondolat, Budapest, 2005.

STiPta 2005b. = STiPTA István: Deák Ferenc állambírósági koncepciója. In: Szabó István (szerk.): „...a hazának szent ügye...”. Emlékülés Deák Ferenc születésének 200. évfordulója alkalmából. Szent István Társulat, Budapest, 2005.77-98.

STIPTA 2010. = STIPTA István: A 19. századi angol közigazgatási jogvédelem és a magyar közigazgatási bíráskodás. In: Homoki Nagy Mária - Balogh Elemér (szerk.): Emlékkönyv Dr. Ruszoly József egyetemi tanár 70. születésnapjára. SZTE JGYPK Juhász Gyula Felsőoktatási Kiadó, Szeged, 2010.793-810.

STIPTA 2013 = STIPTA István: A pénzügyi közigazgatás szervezete Magyarországon 1849 és 1883 között. Miskolci Jogi Szemle VIII. évf. 1. sz. 2013. 18-34.

STIPTA 2016. = STIPTA István: A jelenkori jogtörténet-tudomány (értelmezési kísérlet). Jogtörténeti Szemle XVIII. évf. 3. sz. 2016. 36-40. 
STIPTA 2018. = STIPTA István: Az erdélyi bírósági rendszer közjogi alapjai. In: Veress Emőd (szerk.): Erdély jogtörténete. Forum Iuris, Kolozsvár, 2018. 286-295.

von Stubenrauch 1856. = von STUbenrauch, Moritz: Handbuch der österreichischen Verwaltungs-Gesetzkunde. Nach dem gegenwärtigen Stande der Gesetzgebung. I. k. Verlag von Friedrich Manz, Wien, 1856.

Szabad 1979. = SzABAD György: Az önkényuralom kora (1849-1867). In: Katus László (szerk.): Magyarország története 1848/1890. Akadémiai Kiadó, Budapest, 1979. $435-768$.

Szabó 1909. = Szabó Dezső: A magyar országgyülések története II. Lajos korában. Hornyánszky, Budapest, 1909.

Szabó 2008. = Szabó István: Die Haftung der Exekutive in dem dreigeteilten System der Monarchie. In: Mezey Barna (szerk.): Der österreichisch-ungarische Ausgleich 1867. Rechtsgeschichtliche Forschungsgruppe der Ungarischen Akademie für Wissenschaften an dem Lehrstuhl für Ungarische Rechtsgeschichte Eötvös Lóránd Universität, Budapest, 2008. 129-137.

SzABó 2011. = SzABó István: A bírói normakontroll bevezetése az 1869. IV. törvénycikkben. In: Homoki-Nagy Mária (szerk.): Konferencia a birói hatalomról és az állampolgárságról. Szegedi Egyetemi Kiadó - Juhász Gyula Felsőoktatási Kiadó, Szeged, 2011. 175-184.

SzABó 2017. = SzABó István: Néhány gondolat a miniszterek jogi felelősségéről a Lajtán innen és túl. In: Balogh Judit - Koncz Ibolya Katalin - Szabó István - Tóth J. Zoltán (szerk.): 65 Studia in honorem István Stipta. Károli Gáspár Református Egyetem Állam- és Jogtudományi Kar, Budapest, 2017.417-428.

SZAKÁLY 2001. = SZAKÁLY Ferenc: A hódolt megye története. In: Kosáry Domokos (szerk.): Pest megye monográfiája. Pest Megye Monográfia Közalapítvány, Budapest, 2001.329-543.

SzAmel 1976. = SzAmeL Lajos: A magyar közigazgatástudomány. In: Lőrincz Lajos Nagy Endre - Szamel Lajos (szerk.): A közigazgatás kutatásának tudományos irányzatai. Közigazgatási és Jogi Könyvkiadó, Budapest, 1976. 379-434.

SzÉKeLy 1980. = SzÉKeLY Vera: A központi államigazgatás tisztségviselöi a dualizmus korában. II. k. Magyar Országos Levéltár, Budapest, 1980. Kézirat.

SZÉKELY 2018. = SZÉKELY Tamás: A közigazgatás átalakításának programja. Modernizáció és nemzetállam-építés a dualizmus korában. In: Csibi Norbert - Schwarczwölder Ádám (szerk.): Modernizáció és nemzetállam-épités. Haza és/vagy haladás dilemmája a dualizmus kori Magyarországon. Kronosz, Pécs, 2018. 165-180. 
Szente 1996. = Szente Zoltán: A képviselői összeférhetetlenség szabályozása Magyarországon 1990-ig. In: Soltész István (szerk.): A képviselók jogállása (1. rész). Parlamenti Módszertani Iroda, Budapest, 1996. 272-290.

Szente 2011. = Szente Zoltán: Kormányzás a dualizmus korában. Atlantisz, Budapest, 2011.

SZENTKIRÁLYI 1867. = SZENT KIRÁLYI Móricz: Eszmetöredékek a vármegyék rendezéséról. Budapesti Szemle, Pest, 1867.

SZIJÁRTÓ 2010. = SZIJÁRTÓ M. István: Hivatalviselő elit a 18. századi Somogy vármegyében. In: Hermann István - Karlinszky Balázs (szerk.): Megyetörténet. Egyház-és igazgatástörténeti tanulmányok a Veszprémi Püspökség 1009. évi adománylevele tiszteletére. Veszprémi Érseki és Főkáptalani Levéltár, Veszprém, 2010. 445-466.

SzITA 1980. = SzITA János: Az adóigazgatás szervei a dualizmus első felében. In: Ádám Antal - Benedek Ferenc - Szita János (szerk.):Jogtörténeti tanulmányok. Emlékkönyv Csizmadia Andor hetvenedik születésnapjára. Pécsi Tudományegyetem Állam- és Jogtudományi Kara, Pécs, 1980.385-394.

SzITA 1983. = SzITA János: A magyar közigazgatás területi rendezése a Bach-korszakban és az 1849. március 4-i osztrák alkotmány. In: Csizmadia Andor (szerk.): Jogtörténeti tanulmányok $V$. Tankönyvkiadó, Budapest, 1983.321-338.

SzIVEsSy 1933. = SzIVEssy Lehel: A magyar közigazgatásfejlódése és a reformtörekvések . Szeged Városi Nyomda és Könyvkiadó, Szeged, 1933.

SzŰCs 1984. = SzŰCs Jenő: Az 1267. évi dekrétum háttere: Szempontok a köznemesség kialakulásához. In: Balázs H. Éva - Fügedi Erik - Maksay Ferenc (szerk.): Mályusz Elemér emlékkönyv. Társadalom-és müvelödéstörténeti tanulmányok. Akadémiai Kiadó, Budapest, 1984. 341-394.

TAGÁNYI 1899. = TAGÁNYI Károly: Megyei önkormányzatunk keletkezése. Magyar Tudományos Akadémia, Budapest, 1899.

TAKÁcs 1963. = TAKÁCs Imre: $A$ járási tanácsok feladatai. Közgazdasági és Jogi Könyvkiadó, Budapest, 1963.

Tisza 1865. = Tisza Kálmán: Parlamenti felelös kormány és megyei rendszer. Ráth, Pest, 1865.

TomCsányi 1940. = TomCsány Móric: Magyarország közjoga . Királyi Magyar Egyetemi Nyomda, Budapest, 1940.

TöвÖк 1907. = TöRÖк Pál: A nemesi vármegye megalakulása . Stief, Kolozsvár, 1907.

TRÁVNIK 1868. = TRÁVNIK Antal: Bírósági szervezés hazánkban. Jogtudományi Közlöny III. évf. 3. sz. 1868. 21-22. 
TRINGLI 1997. = TRINGLI István: Két szokásjogi norma a közgyűlések működéséről. Történelmi Szemle XXXIX. évf. 3-4. sz. 1997.387-400.

TRINGLI 1998. = TRINGLI István: Jagelló-kori levelesítő jegyzék Zalából. Levéltári Közlemények LXIX. évf. 1-2. sz. 1998. 3-31.

Tringli 2001. = Tringli István: Pest megye a késő középkorban. In: Kosáry Domokos (szerk.): Pest megye monográfiája. Pest Megye Monográfia Közalapítvány, Budapest, 2001.75-194.

TRINGLI 2009. = TRINGLI István: Megyék a középkori Magyarországon. In: Neumann Tibor - Rácz György (szerk.): Honoris causa. Tanulmányok Engel Pál tiszteletére. MTA Történettudományi Intézete, Budapest, 2009. 487-518.

TRINGLI 2010. = TRINGLI István: Pest és Pilis megye sajátos viszonyai a török hódítás előtt. In: Hermann István - Karlinszky Balázs (szerk.): Megyetörténet. Egyház-és igazgatástörténeti tanulmányok a Veszprémi Püspökség 1009. évi adománylevele tiszteletére. Veszprémi Érseki és Főkáptalani Levéltár, Veszprém, 2010.369-419.

Tuza 2005. = Tuza Csilla: Az abszolutizmuskori levéltár. II. k. Magyar Országos Levéltár, Budapest, 2005.

VARGA 1996. = VARGA Endre: A késői és hanyatló feudalizmus korszaka (1526-1848). In: Bónis György - Degré Alajos - Varga Endre: A magyar birósági szervezet és perjog története. Zala Megyei Bíróság - Magyar Jogász Egylet Zala Megyei Szervezete, Zalaegerszeg, 1996. 82-189.

VARGA 2002. = VARGA Norbert: A köztörvényhatóság létrehozásának előzményei az 1870:XLII. tc. alapján Debrecen szabad királyi városban. Collega VI. évf. 2. sz. 2002. 59-63.

VARGA 2006. = VARGA Norbert: A föispáni tisztség bevezetése Debrecen és Szeged szabad királyi városokban a köztörvényhatósági törvény alapján. In: Mezey Barna - Révész T. Mihály (szerk.): Ünnepi tanulmányok Máthé Gábor 65. születésnapja tiszteletére. Gondolat, Budapest, 2006. 606-623.

VARGA 2007a. = VARGA Norbert: A közigazgatási reform és a helyi politika viszonya Debrecenben és Szegeden (1870-1872). Debreceni Szemle XV. évf. 4. sz. 2007.466-475.

VARGA 2007b. = VARGA Norbert: A köztörvényhatósági törvény (1870:XLII. tc.) létrejötte. Debreceni Jogi Mühely IV. évf. 4. sz. 2007. Online: <http://www. debrecenijogimuhely.hu/archivum/4_2007/a_koztorvenyhatosagi_torveny_ letrejotte/>.

VARGA 2009. = VARGA Norbert: A polgári közigazgatás kiépítése felé tett lépések a dualizmus időszakában. In: Radics Kálmán (szerk.): A Hajdú-Bihar Megyei Levéltár évkönyve. XXXI. k. Hajdú-Bihar Megyei Levéltár, Debrecen, 2009. 227-250. 
VARGA 2010a. = VARGA Norbert: The emergence of bourgeois public administration in bungarian cities (1843-1867). In: Ioana Magos - Monica Stoian: European Legal Studies and Research. II. k. Wolters Kluwer, Timisoara, 2010. 849-857.

VARga 2010b. = VArga Norbert: A közigazgatási reformok Debrecen és Szeged szabad királyi városokban (1870-1872). In: Homoki-Nagy Mária (szerk.): Mezövárosaink jogélete a 18-19. században. Pólay Elemér Alapítvány, Szeged, 2010. 119-133.

VARGA 2011. = VARGA Norbert: A virilizmus bevezetése és a cégek virilis jogának megítélése Szegeden. Jogtörténeti Szemle XIII. évf. 1. sz. 2011.43-47.

VARGA 2013. = VARGA Norbert: A törvényhatósági bizottság alakuló ülése Debrecenben és Szegeden. In: Balogh Elemér - Homoki - Nagy Mária (szerk.): Ünnepi kötet Dr. Blazovich László egyetemi tanár 70. születésnapjára. SZTE-ÁJTK, Szeged, 2013. 715-726.

VARGA 2018a. = VARGA Norbert: A városi tanács működése a magyar közigazgatási rendszerben. Acta Universitatis Szegediensis. Forum. Acta Juridica et Politica VIII. évf. 2. sz. 2018. 443-471.

VARGA 2018b. = VARGA Norbert: A föispán és a városi közigazgatás reformja a polgári korban. Pro Publico Bono - Magyar Közigazgatás VI. évf. 1. sz. 2018. 180-199.

VÉGHely 1886. = VÉGHely Dezső: Emléklapok rendezett-tanácsú Veszprém város közigazgatási életébőll. Krausz Ármin Fia Könyvnyomdája, Veszprém, 1886.

VIROzSIL 1861. = VIROzsIL Antal: Magyarország nyilván-vagy közjoga mint az alkotmánya eredetétól 1847-8-igfennállott. Magyar Királyi Egyetemi Nyomda, Buda, 1861.

VöRÖs 1956. = VÖRÖs Károly: A polgári kori magyar törvényhatósági közigazgatás. Levéltárak Országos Központja, Budapest, 1956.

W. KovÁcs 2010. = W. KovÁcs András: Szolgabírák és járások a középkori Erdélyben. Erdélyi Múzeum LXXII. évf. 3-4. sz. 2010.33-42.

Wertner 1909. = Wertner Mór: Szolgabiró. Századok XLIII. évf. 2. sz. 1909. 155.

ZELLER 1930. = ZELLER Árpád: Az országgyülési képviselök összeférhetetlenségéröl. Az 1901. évi XXIV. törvénycikk keletkezése, magyarázata az eljárási szabályok és az eddigi joggyakorlat alapján. [Szerző], Budapest, 1930.

Zsoldos 1988. = Zsoldos Attila: A szolgabírói tisztségnév kialakulásának kérdéséhez . Levéltári Szemle XXXVIII. évf. 4. sz. 1988. 12-19.

Zsoldos 1994a. = Zsoldos Attila: A megye intézménye a 14. sz. második felében. In: Kristó Gyula (szerk.): Korai magyar történeti lexikon (9-14. század). Akadémiai Kiadó, Budapest, 1994. 488-489. 
Zsoldos 1994b. = Zsoldos Attila: Királyi ember. In: Kristó Gyula (szerk.): Korai magyar történeti lexikon (9-14. század). Akadémiai Kiadó, Budapest, 1994. 354.

Zsoldos 1997. = Zsoldos Attila: „Eléggé nemes férfiak...” A kehidai oklevél társadalomtörténeti vonatkozásairól. In: Káli Csaba (szerk.): Zalai történeti tanulmányok. Zala Megyei Levéltár, Zalaegerszeg, 1997.7-19.

Zsoldos 2003. = Zsoldos Attila: Az özvegy és a szolgabírák. Századok CXXXVII. évf. 4. sz. 2003. 783-808.

Zsoldos 1842a. = Zsoldos Ignác: $A$ 'szolgabirói hivatal. Törvénykezési rész. Református Föiskola, Pápa, 1842.

Zsoldos $1842 \mathrm{~b} .=$ Zsoldos Ignác: A szolgabirói hivatal. Közrendtartási rész. Református Föiskola, Pápa, 1842.

Zsoldos 1842c. = Zsoldos Ignác: A' mezei rendörség' fóbb szabályai. Az 1840:IX. törvényczikkely'nyomán. Református Főiskola, Pápa, 1842.

Zsoldos 1866. = Zsoldos Ignác: A'szolgabirói hivatal. Törvénykezési rész. 4. kiadás, Müller Gyula, Pest, 1866.

ZsupPÁN 1980. = ZsupPÁN F. Tibor: A helyi önkormányzat újjászervezése 1871/72ben. Századok CXIV. évf. 2. sz. 1980. 260-280.

\section{Jogforrások}

Törvények

- Márkus Dezső (szerk.): Magyar Törvénytár. Budapest, Franklin-Társulat, 1900.

- 1342. évi decretum

- 1435. évi első decretum (Zsigmond ötödik decretuma) 6. cikkely Hogy a szolgabiró köteles a vármegyében létezö minden jobbágy lajstromát az ispán kezébez szolgáltatni.

- 1435. évi második decretum (Zsigmond hatodik decretuma) 1. cikkely Az ország rendes biráiról és azok esküjéröl.

- 1435. évi második decretum (Zsigmond hatodik decretuma) 2. cikkely A szolgabirák választásáról.

- 1435. évi második decretum (Zsigmond hatodik decretuma) 7. cikkely Hogy a mérsékelt birságokat kiknek és mikor kell behajtaniok. 
- 1454. évi decretum (V. László második decretuma) 15. cikkely Hogy az ispán és a szolgabirák minden hatalmaskodás és birtokfoglalás tárgyában büntetés terhe alatt itélni s az itéletet végrehajtani tartoznak.

- 1458. évi decretum (Horogszegi Szilágyi Mihály decretuma) 15. cikkely Hogy minden jobbágyot a fekvojjószágok elfoglalásának és tizenkét márka fizetésének terhe alatt szabadon el kell bocsátani.

- 1486. évi decretum (I. Mátyás hatodik decretuma) 8. cikkely Mindenik vármegyében válaszszanak királyi embereket, kiknek a hiteles bizonyságokkal a végrehajtásokra ki kell menniök; és büntetésük, ha csalást követnek el.

- 1486. évi decretum (I. Mátyás hatodik decretuma) 9. cikkely Szolgabirákul az egyes megyékben tehetösebbeket válaszszanak, és azok büntetéséröl, ha a tisztségeket nem akarnák elvállalni.

- 1486. évi decretum (I. Mátyás hatodik decretuma) 60. cikkely Hogy az egyes megyék élére ispánokat kell tenni, és hogy ezek az ispánok ugyanabból a megyéböl kötelesek maguknak tekintélyes férfiakat alispánokul kiválasztani; és azok esküjéröl.

- 1492. évi decretum (II. Ulászló első decretuma) 33. cikkely $A$ nádor hatalmáról, a királyi birákról és tisztekröl, az ispánokról és a rendes birák ülnökeiröl, helyetteseiröl, itéló mestereiröl és ezek esküjének alakjáról.

- 1492. évi decretum (II. Ulászló első decretuma) 34. cikkely Az egyes megyékben választandó szolgabirákról.

- 1492. évi decretum (II. Ulászló első decretuma) 53. cikkely $A$ vármegyékben ne választott és esküdt nemesek, hanem az ispánok, alispánok és szolgabirák itéljenek, a végrehajtásokban pedig királyi és káptalani emberek járjanak el.

- 1495. évi decretum (II. Ulászló második decretuma) 15. cikkely Azokról, kik az ispánok joghatósága alól ki vannak véve.

- 1495. évi decretum (II. Ulászló második decretuma) 20. cikkely Pest és Pilis vármegyéröl, a hol az ispánokat a szolgabirák helyettesitik.

- 1498. évi decretum (II. Ulászló harmadik decretuma) 15. cikkely Miképen kell az érsekeknek, püspököknek és a többi zászlós és nem zászlós egyházi férfiaknak a királylyal katonáskodniok? és hogy a kisebb javadalmuak minden harminczhat kapu után egy lovast küldjenek a hadba.

- 1498. évi decretum (II. Ulászló harmadik decretuma) 71. cikkely $A z$ ispánok és alispánok a biróságuk elébe tartozó ügyeket parancslevél nélkül itéljék meg és hajtsák végre vagy az ügy érdeme ugy kivánván, fellebbezésre is bocsássák.

- 1504. évi decretum (II. Ulászló ötödik decretuma) 16. cikkely A jobbágyok a szolgabiráktól nyerjenek engedélyt a költözésre. 
- 1523. évi decretum 4. cikkely Minden egyes megyébe követ küldendö ki, hogy megvizsgálja, mekkora adóösszeget vetettek ők ki és mekkorát hajtottak be?

- 1527. évi decretum 6. cikkely A gonosztevök és pártfogóik megbüntetendök.

- 1528. évi decretum 4. cikkely Miképen járjanak el az ispánok és alispánok a pártütök ellen.

- 1528. évi decretum 6. cikkely Az ispánok és szolgabirák a szokott fizetést kapják.

- 1528. évi decretum 32. cikkely Az ispánok és alispánok hatalmat nyernek, hogy károk és fosztogatások esetében száz forinton felül biráskodhassanak.

- 1536. évi decretum 6. cikkely $A z$ ispánok és alispánok hatalmat nyernek, hogy károk és fosztogatások esetében száz forinton felül biráskodhassanak.

- 1546. évi decretum 9. cikkely A királyi segély behajtásának a módja.

- 1547. évi 27. cikkely Mikor szabad a jobbágynak máshová költözni?

- 1547. évi 31. cikkely $A$ szolgabirók itéletét a vármegye székére, és innen a királyi táblára szabad fölebbezni.

- 1548. évi 42. cikkely Milyen okból szabad a jobbágynak ura fekvöjószágairól elköltöznie?

- 1548. évi 50. cikkely $A z$ ispánok és alispánok a gonosztevöket negyedévenkint nyomozzák.

- 1550. évi 24. cikkely A szolgabiró menjen ki arra a helyre, a hol a pusztulás állitólag történt és szemmel látott hitelességgel puhatolja ki, vajjon van-e hiány a kapuk számában?

- 1550. évi 31. cikkely Az alispánok, szolgabirák és jegyzőók dijai az adóból fizetendók ki.

- 1554. évi 4. cikkely Két forint segélynek megajánlása.

- 1556. évi 28. cikkely $A$ költözködni akaró jobbágyot a szolgabiró az esküdttel szabadságolja és szállitsa át.

- 1563. évi 20. cikkely Az alispánok hivataluk vesztésének és ötven forint büntetésének terhe alatt, három márka birság mellett kényszeritsék az ingyen munkát teljesiteni vonakodókat a munkára.

- 1567. évi 10. cikkely $A z$ adókivetö akarata nélkül diját senki az adóból ne kapja. Az alispánnak tizenkét, a szolgabiráknak négy és a jegyzönek egy forintot fizessenek.

- 1588. évi 40. cikkely A szolgabiró a tiszta adósságokban husz forintig itéljen.

- 1593. évi 16. cikkely $A$ katonák tartásáról. 
- 1598. évi 8. cikkely Az eljárás módja a házak számbavételénél.

- 1602. évi 17. cikkely $A$ hátralékok felhajtásának módjáról.

- 1603. évi 3. cikkely Az ország rendei a mult évben, a katonaság tartására határozott segélyt, két határidóben való fölszedés mellett, erre az évre is megajánlják. Ennek a felszedése módjáról, továbbá a fó és a vidéki pénzbevevoókröl, meg ezeknek a fizetéséröl.

- 1609. évi 29. cikkely A mult országgyülés végzései közül, az eröszakosságokra és a jószágfoglalásokra nézve kelt 3. és 4. czikkelyeknek érvényben hagyása, helyes értelmezése és az azokban való eljárás módja.

- 1609. évi 62. cikkely A kapuk uj számbavételének az intézéséról és arról, hogy adókivetőkké kiket kell választani? A kapuk összeszámlálásánál mikép kell eljárni? A megajánlott négy magyar forint adót mi módon és minö szükségletre kell forditani? és hogy az adózásnak kik vannak alávetve, meg, hogy az emlitett két évre terjedó adót minö határidókben kell fölszedni?

- 1613. évi 8. cikkely A véghelyekhez, a vármegyék részéröl teljesitendö ingyenmunkák szabályozásáról.

- 1613. évi 23. cikkely Az eröszakosságokról és a jószágfoglalásokról a korábbi országygyüléseken kelt törvényczikkelyeknek világosabb megmagyarázása.

- 1613. évi 24. cikkely Az elökelöbb nemesség közül választandó rendkivüli esküdt ülnökökröl és ezek tisztéröl.

- 1618. évi 41. cikkely A kapuk uj számbavétele módjának a megtartására.

- 1647. évi 129. cikkely $A$ Rába folyó kitisztitására nézve az e részben hozott czikkelyeket megujitják.

- 1647. évi 153. cikkely Az ország végvidékei részére teljesitendö ingyenmunkáknak a rendjét meghatározzák.

- 1649. évi 86. cikkely Az ország egyes végvidékei részére teljesitendö ingyenmunkák rendjének a megállapitása.

- 1681. évi 7. cikkely Az ingyen munkákról, melyeket az ország törvényei, nem pedig holmi a jelen mozgalmak alatt behozott jegyzékek szerint kell a törvényben kijelölt belyekre szolgáltatni.

- 1723. évi 30. törvénycikk A kerületi táblák felállitásáról, és az azoknál alkalmazandó személyekröl.

- 1723. évi 56. törvénycikk A fóispánoknak megyéikben lakásáról a megyék tisztujitásáról, az alispánok smás tisztviselók állásáról. 
- 1723. évi 73. törvénycikk Annak a helynek a földesurak birtokain leendö átengedéséröl, a hol Tolna és más hasonló állapotban levö megyék törvényszékeiket tartsák, hivatalos irataikat örizzék s a törvényhatósági hatalmat gyakorolják.

- 1729. évi 22. törvénycikk A vadászat és madarászat szabályozásáról.

- 1729. évi 28. törvénycikk Mely ügyeket kell birtokon kivül felebbezni?

- 1729. évi 35. törvénycikk $A$ megyei biráskodásról.

- 1807. évi 8. törvénycikk A perek gyorsabb folyásának elömozditásáról.

- 1808. évi 11. törvénycikk A most megajánlott follkelés kiállitásának esetére megtartandófegyelmi törvények.

- 1836. évi 4. törvénycikk A jobbágyok költözése eseteiben tartandó módróls rendröl, és ugyan azon költözés következményeiröl.

- 1840. évi 9. törvénycikk $A$ mezei rendörségröl.

- 1844. évi 9. törvénycikk $A$ közmunkák szabályozásáról.

- 1848. évi V. törvénycikk Az országgyülési követeknek népképviselet alapján választásáról.

- 1848. évi XXIV. törvénycikk A községi választásokra nézve.

- 1868. évi XXI. törvénycikk A közadók kivetése, befizetése, biztositása, behajtása és pénzügyi törvényszékek felállitása iránt.

- 1868. évi XXXVIII. törvénycikk A népiskolai közoktatás tárgyában.

- 1868. évi XL. törvénycikk $A$ véderöröl.

- 1868. évi LIV. törvénycikk A polgári törvénykezési rendtartás tárgyában.

- 1869. évi IV. törvénycikk A birói hatalom gyakorlásáról.

- 1870. évi XVIII. törvénycikk Az állami számvevöszék felállitásáról s hatásköréröl.

- 1870. évi XLII. törvénycikk A köztörvényhatóságok rendezéséröl.

- 1871. évi XVIII. törvénycikk A községek rendezéséröl.

- 1871. évi XXXII. törvénycikk Az elsó folyamodásu kir. törvényszékek és járásbiróságok életbeléptetéséröl.

- 1873. évi XI. törvénycikk Baja és Hódmezö-Vásárhely városoknak törvényhatósági joggal való felruházásáról.

- 1875. évi I. törvénycikk Az összeférhetetlenségröl. 
- 1876. évi XXXIII. törvénycikk Némely törvényhatóság területének szabályozásáról és az ezzel kapcsolatos intézkedésekröl.

Rendeletek

- 250. Kaiserliches Patent von 3. December $1852=250$. Kaiserliches Patent von 3. December 1852, wirksam für die Kronländer Oesterreich unter und ob der Enns, Salzburg, Steiermark, Kärnthen, Krain, Görz, Gradiska, Istrien, Triest, Tirol und Vorarlberg, Böhmen, Mähren, Schlesien, Galizien, mit Krakau und die Bukowina, wodurch für diese Kronländer ein neues Forstgesetz erlassen, und vom 1. Jänner 1853 angefangen in Wirksamkeit gesetzt wird. Allgemeines Reichs-Gesetz und Regierungsblatt für das Kaiserthum Oesterreich. Jahrgang 1852, 72. sz. Ausgegeben und versendet am 14. December 1852. 1053-1080.

- 24. A' bel-, igazság- és pénzügyi ministereknek 1853-diki január 19-kén kelt rendelete $=24$. A' bel-, igazság- és pénzügyi ministereknek 1853-diki január 19-kén kelt rendelete, mellyel a’ magyarországi helytartóság, megyei hatóságok és szolgabírói hivatalok szerkezetét és hivalos hatályát, továbbá a’ birói hatóságok szerkezetét és a’ rendszeresített fizetések és napdijak vázlatát, nemkülönben ezen szervezet létesítését tárgyazó legfelsőbb határozványok tétetnek közhírré. Magyarországot illető Országos Kormánylap. IV. évf. 3. sz. (1853. február 24.) 75-122.

- 10. Verordnung der Minister des Innern, der Justiz und der Finanzen vom 19. Jänner $1853=10$. Verordnung der Minister des Innern, der Justiz und der Finanzen vom 19. Jänner 1853, womit die Allerhöchsten Entschließungen über die Einrichtung und Amtswirksamkeit der Bezirksämter, Kreibehörden und Statthaltereien, über die Einrichtung der Gerichtsstellen und das Schema der systemisirten Gehalte und Diätenclassen, sowie über die Ausführung der Organisirung für die Kronländer Oesterreich ob und unter der Enns, Böhmen, Mähren, Schlesien, Galizien und Lodomerien mit Krakau, Bukowina, Salzburg, Tirol mit Vorarlberg, Steiermark, Kärnthen, Krain, Görz, Gradiska und Istrien mit Triest, Dalmatien, Kroatien und Slawonien, Siebenbürgen, die Serbische Wojwodschaft mit dem Banate, kundgemacht werden. Reichs-Gesetz-Blatt für das Kaiserthum Oesterreich. Jahrgang 1853, 4. sz. Ausgegeben und versendet am 22. Jänner 1853. 65-110.

- 85. szám. A' bel-, igazság és pénzügyi ministeriumoknak 1854. april 6-kán kelt rendelete $=85$. szám. A' bel-, igazság és pénzügyi ministeriumoknak 1854. april 6-kán kelt rendelete, Magyarország politikai és birósági szervezete tárgyában. Magyarországot illető Országos Kormánylap. V. évf. 7. sz. (1854. május 15.) 179-197. 
- 136. Verordnung der Ministerien des Innern, der Justiz und der Finanzen vom 3. Juni $1854 .=136$. Verordnung der Ministerien des Innern, der Justiz und der Finanzen vom 3. Juni 1854, betreffend die politische und gerichtliche Organisirung der Königreiche Kroatien und Slawonien. Reichs-Gesetz-Blatt für das Kaiserthum Oesterreich. Jahrgang 1854, 49. sz. Ausgegeben und versendet am 9. Juni 1854. 497-509.

- 141. Verordnung der Ministerien des Innern, der Justiz und der Finanzen vom 4. Juni 1854. = 141. Verordnung der Ministerien des Innern, der Justiz und der Finanzen vom 4. Juni 1854, betreffend die politische und gerichtliche Organisirung des Großfürstenthumes Siebenbürgen. Reichs-Gesetz-Blatt für das Kaiserthum Oesterreich. Jahrgang 1854, 51. sz. Ausgegeben und versendet am 13. Juni 1854. 513-540.

- 88. Kaiserliche Verordnung vom 20. Juni $1858=88$. Kaiserliche Verordnung vom 20. Juni 1858, wirksam für alle Kronländer, mit Ausnahme des lombardischvenetianischen Königreiches und der Militärgrenze, wodurch die Gerichtsbarkeit über mehrere Uebertretungen des allgemeinen Strafgesetzes den politischen Behörden zugewiesen, und das hierüber von diesen Behörden zu beobachtende Strafverfahren geregelt wird. Reichs-Gesetz-Blatt für das Kaiserthum Oesterreich. Jahrgang 1858, 24. sz. Ausgegeben und versendet am 23. Juni 1858. 383-388.

- 227. Kaiserliches Patent vom 20. December $1859=227$. Kaiserliches Patent vom 20. December 1859, womit eine Gewerbe-Ordnung für den ganzen Umfang des Reiches, mit Ausnahme des venetianischen Verwaltungsgebietes und der Militärgrenze, erlassen, und vom 1. Mai 1860 angefangen in Wirksamkeit gesetzt wird. Reichs-Gesetz-Blatt für das Kaiserthum Oesterreich. Jahrgang 1859, 65. sz. Ausgegeben und versendet am 27. December 1859.619-650.

- 28. Verordnung der Ministerien des Innern und der Justiz vom 30. Jänner $1860=$ 28. Verordnung der Ministerien des Innern und der Justiz vom 30. Jänner 1860, wirksam für alle Kronländer, mit Ausnahme des venetianischen Verwaltungsgebietes, des Königreiches Dalmatien und der Militärgrenze, betreffend die Bestellung eines beeideten Feldschutzpersonales und das Verfahren über Feldfrevel. ReichsGesetz-Blatt für das Kaiserthum Oesterreich. Jahrgang 1860, 6. sz. Ausgegeben und versendet am 2. Februar 1860. 59-66.

- 17. előterjesztvény a köztörvényhatóságok visszaállításáról = 17. A ministerium előterjesztvénye 1867. febr. 25-ről a köztörvényhatóságok visszaállítása tárgyában. Magyarországi törvények és rendeletek tára. I. évf. 1867.30-33.

- 58. A m. k. pénzügy ministerium rendelete az adóbehajtásról = 58. A m. k. pénzügy ministeriumnak 1867. május 23-án kelt rendelete Magyarország valamennyi törvényhatóságához az adóbehajtás kérdésében. Magyarországi rendeletek tára. I. évf. 1867. 145-147. 
- 86. rendelet az erdélyi törvényhatóságok helyreállításáról $=86$. Az összes m. $\mathrm{k}$. ministeriumnak 1867. évi jun. 27-kén közzétett rendelete, az erdélyi köztörvényhatóságok alkotmányos hatáskörének visszaállitása iránt. Magyarországi törvények és rendeletek tára. I. évf. 1867. 187.

- 84. A magyar királyi honvédelmi ministerium körrendelete = 84. A magyar királyi honvédelmi ministerium körrendelete valamennyi törvényhatósághoz. Magyarországi rendeletek tára. III. évf. 1869.730-744.

- 86. A honvédelmi ministerium körrendelete a sorozási ügyről = 86. A honvédelmi $\mathrm{m}$. kir. ministerium körrendelete, valamennyi törvényhatósághoz a sorozási ügy törvényszerű foganatositása végett követendő eljárás részletezése tárgyában. Magyarországi rendeletek tára. III. évf. 1869.745-749.

- 24. A m. kir. pénzügyminister körrendelete $=24$. A m. kir. pénzügyminister 1871 . évi június hó 4-én 2653. sz. a. kelt körrendelete, a megyék, kerületek, vidékek és székek közönségéhez a háziadó javára leszállított egyenes adók kevesedése iránt. Magyarországi törvények és rendeletek tára. V. évf. 1871. 85-93.

- 39. ministeriumi rendelet $=39$. A királyi ministerium rendelete Az első folyamodásu királyi törvényszékek és járásbiróságok székhelyeinek megállapitása tárgyában. Magyarországi rendeletek tára. V. évf. 1871.

- Ideiglenes szabályzat a Királyföldön = 39. A Magyarország és Erdély egyesítésének részletes szabályozásáról szóló 1868 XLIII. t.cz 10. \$-a értelmében a m. k. belügyminister által kibocsátott ideiglenes szabályzat a képviselö-testületek, valamint a széki, vidéki és községi tisztviselők választására nézve, a Királyföldön. (Ideiglenes szabályzat a Királyföldön). Magyarországi rendeletek tára. III. évf. 1869. 241-247.

\section{Országgyủlési nyomtatványok}

KI 1865. I. k. = Az 1865-dik évi december hó 10-dikére hirdetett országgyülés képviselöházának irományai. I. k. Pest, Emich Gusztáv, 1866.

KI 1865. VII. k. = Az 1865-dik évi december hó 10-dikére hirdetett országgyülés képviselóházának irományai. VII. k. Pest, Athenaeum, 1868.

KI 1869. III. k. = Az 1869-dik évi april hó 20-dikára hirdetett országgyülés képviselöházának irományai. III. k. Pest, Deutsch-féle Könyvnyomda, 1870.

KI 1869. V. k. = Az 1869-dik évi april hó 20-dikára hirdetett országgyülés képviselöházának irományai. V. k. Pest, Deutsch-féle Könyvnyomda, 1870.

KI 1869. VI. k. = Az 1869-dik évi april hó 20-dikára hirdetett országgyülés képviselöházának irományai. VI. k. Pest, Deutsch-féle Könyvnyomda, 1870. 
KI 1869. IX. k. = Az 1869-dik évi april hó 20-dikára hirdetett országgyülés képviselöházának irományai. IX. k. Pest, Deutsch-féle Könyvnyomda, 1871.

KI 1869. XV. k. = Az 1869-dik évi april hó 20-dikára hirdetett országgyülés képviselöházának irományai. XV. k. Pest, Deutsch-féle Könyvnyomda, 1872.

KI 1872. IX. k. = Az 1872. évi september hó 1-jére hirdetett országgyülés képviselóházának irományai. IX. k. Buda, Magyar Királyi Államnyomda, 1874.

KI 1872.X. k. = Az 1872. évi september hó 1-jére hirdetett országgyülés képviselöházának irományai. X. k. Buda, Magyar Királyi Államnyomda, 1874.

KI 1872. XI. k. = Az 1872. évi september hó 1-jére hirdetett országgyülés képviselóházának irományai. XI. k. Buda, Magyar Királyi Államnyomda, 1874.

KI 1872. XVII. k. = Az 1872. évi september hó 1-jére hirdetett országgyülés képviselöházának irományai. XVII. k. Buda, Magyar Királyi Államnyomda, 1874.

KN 1865. III. k. = Greguss Ágost (szerk.): Az 1865-dik évi deczember 10-dikére hirdetett országgyülés képviselóházának naplója. III. k. Pest, Emich Gusztáv, 1867.

KN 1865. X. k. = GREGUSS Ágost (szerk.): Az 1865-dik évi deczember 10-dikére hirdetett országgyülés képviselóházának naplója. X. k. Pest, Athenaeum, 1868.

KN 1865. XI. k. = GREGUSS Ágost (szerk.): Az 1865-dik évi deczember 10-dikére hirdetett országgyülés képviselóházának naplója.XI. k. Pest, Athenaeum, 1868.

KN 1869. II. k. = GREguss Ágost (szerk.): Az 1869-dik évi april 20-dikára hirdetett országgyülés képviselóházának naplója. II. k. Pest, Légrády testvérek, 1869.

KN 1869. IX. k. = NAGY Iván (szerk.): Az 1869-dikévi april 20-dikára hirdetett országgyülés képviselöházának naplója. IX. k. Pest, Légrády Testvérek, 1870.

KN 1869.X. k. = NAGY Iván (szerk.): Az 1869-dik évi april 20-dikára hirdetett országgyülés képviselóházának naplója. X. k. Pest, Légrády Testvérek, 1870.

KN 1869. XV. k. = NAGY Iván (szerk.): Az 1869-dik évi april 20-dikára hirdetett országgyülés képviselóházának naplója.XV. k. Pest, Légrády Testvérek, 1871.

KN 1869. XVI. k. = NAGY Iván (szerk.): Az 1869-dik évi april 20-dikára birdetett országgyülés képviselóházának naplója. XVI. k. Pest, Légrády Testvérek, 1871.

KN 1869. XXII. k. = NAGY Iván (szerk.): Az 1869-dik évi april 20-dikára birdetett országgyülés képviselóházának naplója. XXII. k. Pest, Légrády Testvérek, 1872.

KN 1872. II. k. = NAGY Iván (szerk.): Az 1872-ikévi september 1-re hirdetett országgyülés képviselóházának naplója. II. k. Buda, Magyar Királyi Államnyomda, 1872.

KN 1872. VIII. k. = NAGY Iván (szerk.): Az 1872-ik évi september 1-re hirdetett országgyülés képviselóházának naplója. VIII. k. Buda, Magyar Királyi Államnyomda, 1874. 
KN 1872. X. k. = NAGY Iván (szerk.): Az 1872-ik évi september 1-re hirdetett országgyülés képviselóházának naplója. XI. k. Buda, Magyar Királyi Államnyomda, 1874.

KN 1872. XI. k. = NAGY Iván (szerk.): Az 1872-ik évi september 1-re hirdetett országgyülés képviselóházának naplója. XI. k. Buda, Magyar Királyi Államnyomda, 1874.

FN 1872. II. k. = Az 1872-dik évi szeptember hó 1-jére hirdetett országgyülés förendi házának naplója. II. k. [Pest], Pesti Könyvnyomda, 1873.

\section{Napilapok}

- PN 1853/861. = A közigazgatási s törvényszéki szervezet Magyarországon. Pesti Napló IV. évf. 861. sz. (1853. január 22.)

- BH 1853/18. = Budapesti Hírlap I. évf. 18. sz. (1853. január 21.)

- PN 1853/862. = Rendelete. Pesti Napló IV. évf. 862. sz. (1853. január 23.)

- BH 1853/19. = Rendelete. Budapesti Hírlap I. évf. 19. sz. (1853. január 22.)

- PN 1854/1229. = Hivatalos. Pesti Napló V. évf. 1229. sz. (1854. április 14.)

- BH 1854/394. = Rendelete. Budapesti Hírlap II. évf. 394. sz. (1854. április 14.)

- PN 1854/1243. = Május 1. 1854. Pesti Napló V. évf. 1243. sz. (1854. május 2.)

- PN 1854/1261. = Pesti Napló V. évf. 1261. sz. (1854. május 23.)

- BH 1854/409. = Budapesti Hírlap II. évf. 409. sz. (1854. május 2.)

- BH 1858/160. = Budapesti Hírlap VI. évf. 160. sz. (1858. július 16.)

- BH 1859/44. = Budapesti Hírlap VII. évf. 44. sz. (1859. február 24.)

- Sürgöny 1862/118. = Hivatalos rész. Sürgöny II. évf. 118. sz. (1862. május 22.)

- Sürgöny 1864/21. = Hivatalos rész. Sürgöny IV. évf. 21. sz. (1864. január 27.)

- Sürgöny 1864/22. = A nmlgu magyar királyi helytartótanács. Sürgöny IV. évf. 22. sz. (1864. január 28.)

- BK 1867/60. = Budapesti Közlöny I. évf. 60. sz. (1867. május 22.)

- BK 1867/72. = Budapesti Közlöny I. évf. 72. sz. (1867. június 6.)

- BK 1867/75. = Budapesti Közlöny I. évf. 75. sz. (1867. június 9.)

- BK 1867/85. = Budapesti Közlöny I. évf. 85. sz. (1867. június 23.) 
- BK 1867/174. = Budapesti Közlöny I. évf. 174. sz. (1867. október 9.)

- BK 1867/218. = Budapesti Közlöny I. évf. 218. sz. (1867. november 30.)

- PN 1868/11. = Pesti Napló XIX. évf. 11. sz. (1868. január 15.)

- BK 1868/16. = Budapesti Közlöny II. évf. 16. sz. (1868. január 21.)

- BK 1869/136. = Budapesti Közlöny III. évf. 136. sz. (1869. június 17.)

- BK 1870/3. = Budapesti Közlöny IV. évf. 3. sz. (1870. január 5.)

- BK 1871/25. = Budapesti Közlöny V. évf. 25. sz. (1871. január 31.)

- BK 1871/131. = Budapesti Közlöny V. évf. 131. sz. (1871. június 10.)

- BK 1872/39. = Budapesti Közlöny VI. évf. 39. sz. (1872. február 18.)

- BK 1872/121. = Budapesti Közlöny VI. évf. 121. sz. (1872. május 29.)

- BK 1872/160. = Budapesti Közlöny VI. évf. 160. sz. (1872. július 16.)

- BK 1872/239. = Budapesti Közlöny VI. évf. 239. sz. (1872. október 18.)

- BK 1872/241. = Budapesti Közlöny VI. évf. 241. sz. (1872. október 20.)

- BK 1873/63. = Budapesti Közlöny VII. évf. 63. sz. (1873. március 16.)

- BK 1885/246. = Budapesti Közlöny XIX. évf. 246. sz. (1885. október 28.)

- PH 1887/270. = Elhaltak névsora Budapesten 1887. szeptember 27. Pesti Hírlap IX. évf. 270. sz. (1887. október 2.)

- BK 1888/208. = Budapesti Közlöny XXII. évf. 208. sz. (1888. szeptember 7.)

- BK 1889/140. = Budapesti Közlöny XXIII. évf. 140. sz. (1889. június 16.)

- BK 1889/171. = Budapesti Közlöny XXIII. évf. 171. sz. (1889. július 25.)

- BK 1896/300. = Budapesti Közlöny XXX. évf. 300. sz. (1896. december 19.)

- BeK 1896/1. = Belügyi Közlöny I. évf. 1. sz. (1896. május 1.)

- BK 1897/100. = Budapesti Közlöny XXXI. évf. 100. sz. (1897. május 2.)

- BeK 1897/1. = Belügyi Közlöny II. évf. 1. sz. (1897. január 1.)

- BH 1905/116. = Budapesti Hírlap XXV. évf. 116. sz. (1905. április 27.)

- PN 1905/116. = Pesti Napló LVI. évf. 116. sz. (1905. április 27.)

- NéPszava 1905/61. = Népszava XXXIII. évf. 61. sz. (1905. április 27.)

- BH 1906/189. = Budapesti Hírlap XXVI. évf. 189. sz. (1906. július 12.) 
- BH 1915/94. = Csávossy Béla báró meghalt. Budapesti Hírlap XXXV. évf. 94. sz. (1915. április 4.)

\section{Felhasznált levéltári források}

Magyar Nemzeti Levéltár Országos Levéltára (MNL OL)

- Abszolutizmuskori Levéltár Szervező bizottmányok 1853-1854, D134 K. K. Organisierungs Commission Ofen 191/1853.

- Belügyminisztériumi iratok (MNL BM) K150 C/ Általános iratok

110. csomó

1067/1871. - Csanád megye közönsége a mértföldenkinti előfogati dij leszállítása iránt hozott határozatát felterjeszti.

111. csomó

76/1869.; Sz263/1869.; 6933/1870.; 15854/1870; 9339/1871. - Orsz. képviselő ház átteszi, a képviselői állás és kórmány-hivatal összeférhetlensége tárgyában kelt feliratokat.

6311/1869.; 24922/1869.; 8902/1870.; 6992/1871. - Marmaros megye közönségének felterjesztése a megyei tisztviselők napidijainak szabályozása tárgyában.

14588/1871. - Veszprém megye alispánja Matkovits Tivadarnak Csapó Ignácz tiszteletbeli esküdt ellen fenforgó ügyében a tiszti ügyészi véleményt felterjeszti.

112. csomó

1871. II. 2. tétel 1592/1871. - Nográd megye alispánja felterjeszti Varga Mihály megyei hajdúnak nyugdijaztatása iránt benyújtott folyamodványát. 1871. II. 3. tétel 18517/1870.-Sárospataki lakos Toth Pápay Sándor Zemplén megyei volt csendbiztos később jegyző - nyugdijért folyamodik.

117. csomó

12183/1871. - a köztörvényhatóságok rendezéséről szóló 1870ik évi 42ik t. czikk végrehajtása tárgyában.

15251/1871. - a köztörvényhatóságok rendezéséről szóló 1870ik évi XLIIik t. czikk végrehajtása tárgyában.

24502/1871. - a törvényhatósági szervezésre vonatkozó munkálatnak felterjesztése iránt.

27793/1871. - a szervezési munkálatnak felterjesztése iránt.

15501/1871. - Bihar megye közönségének előterjesztvénye, - melyben a legtöbb adót fizetők névsorát, és a m. $\mathrm{k}$. járásbiróságok beosztását kéri megküldeni. 
18839/1871. - Bihar megye közönsége a járás biróságok területi beosztása iránt létrejött megállapodást közölni kéri.

17731/1871.; 17731Sz/1871.; 18194/1871.; 32702/1871. - Arad vármegye. 20171/1871. - Aranyosszék.

21799/1871.; 28287/1871. - Bars vármegye.

21161/1871.; 31913/1871. - Békés vármegye.

17803/1871.; 27291/1871.; 32776/1871. - Csanád vármegye.

21068/1871.; 27282/1871. - Csongrád vármegye.

21272/1871.; 21265/1871.; 29721/1871. - Doboka vármegye.

17808/1871.; 27079/1871. - Fejér vármegye.

22026/1871.; 34430/1871. - Felső-Fehér vármegye.

21800/1871.; 29328/1871. - Fogaras vidék.

22226/1871.; 32636/1871. - Krassó vármegye.

20826/1871.; 27062/1871. - Sáros vármegye.

21797/1871. - Szepes vármegye.

21949/1871. - Temes vármegye.

20991/1871.; 28525/1871. - Trencsén vármegye.

21798/1871.; 31267/1871. - Zala vármegye.

118. csomó

23346/1871.; 31726/1871. - Alsó-Fehér vármegye.

22592/1871.; 27001/1871. - Bereg vármegye.

23816/1871.; 32032/1871.; 32051/1871. - Gömör és Kis-Hont vármegye.

28726/1871.; 31986/1871.; 33141/1871. - Hont vármegye.

23336/1871. - Hajdú kerület.

23891/1871. - Hunyad vármegye.

22326/1871.; 30274/1871.; 34064/1871. - Komárom vármegye.

22499/1871. - Kövár vidék.

22187/1871. - Közép-Szolnok vármegye.

25309/1871.; 31404/1871. - Küküllő vármegye.

24696/1871-Nagy-Kikinda kerület.

22691/1871.; 28989/1871. - Nógrád vármegye.

26616/1871.; 31697/1871. - Pozsony vármegye.

32644/1871. - Szabolcs vármegye.

22336/1871.; 30172/1871.; 736/1871. megyei állandó bizottmány köz-

gyűlése-Veszprém vármegye.

25636/1871. - Zaránd vármegye

491/LIX. 71.; 32825/1871. - Heves és Külső-Szolnok vármegye felirata. 
152. csomó 1872 . II. 2.

25042/1869.; 1918/1870.; 7714/1871.; 4513/1872.; 39418/1872.-Hárómszék tisztsége Bardócz Lajosnak altorjai B. Apor János volt dúló ellen hivataloskodása alatt eltévesztett 92 Ft 33 krról szóló eredeti váltó értékének s az ebbül felmerült költségek megtérítése iránt fennforgó ügyében f. évi 4367 szám alatt kelt tisztségi végzés ellen közbesett felfolyamodványát jelentés és vonatkozó ügyiratok kiséretében felterjeszti.

16793/1871.; 6157/1872.-Holczer Dániel cs.keresztúri lakos beadványa, melyben egy adóssági peres ügyében a pestesi járás szolgabírája által hozott határozatot neheztelvén, panaszolt ügyében orvoslást kér.

7578/1872.; 9629/1872.-Torna megye alispánja jelenti, hogy a Burger Sámuel, miskolczi lakos által Burger József, szilaszi lakos, ellen indított summás visszahelyezési perre vonatkozó ügyiratok a tornai kir. járásbírósághoz áttétettek.

8608/1872.; 29173/1872.-Csongrád megye alispánja jelenti, hogy a szegvári volt szolgabíróságnál maradt törvénykezési iratok a szentesi kir. járásbíróság részére f. évi Augusztus hó 29-én átadattak.

8832/1872.; 18162/1872.-Pozsony vármegye.

9048/1872.; 22648/1872.-Veszprém vármegye.

21995/1872.-Torna vármegye.

153. csomó

17532/1871. - Pest vármegye közönségének a vitássá tett tiszti helyettesítés kérdésének megoldására vonatkozó előterjesztésére.

33617/1872.-Mármaros megye alispánja felterjeszti Markos István és érdektársainak a képviselővé választott Szaplonczai Miklos tiszavölgyi járási szolgabiró állomása betöltése iránt hozott megyei határozat ellen intézett felfolyamoványát.

25192/1872.-Nyitra vármegye a miavai szolgabíró és járásbíró összeütközése. 15818/1872.-Arad vármegye.

24258/1872.-Bihar vármegye.

23836/1872.-Torontál vármegye;

9141/1872.; 24138/1872.; 39577/1872.; 42369/1872.-Ung vármegye

217. csomó

42404/1872.-Zala megye alispánja Nagy Farkas, Zala egerszegi járási volt föszolgabírónak, perbefogatása következtében leállított fizetésének a beszüntetés napjától vagyis 1869ik évi május 20ikáról 1871ik évi december 27ikéig mint fölmentése napjáig leendő kiszolgáltatását megtagadó f. é. november 4ikén 5012/309. sz. a. hozott határozat ellen beadott felfolyamodványát felterjeszti. 
233. csomó

28463/1873.-Moson vármegye.

- W/12 Minisztertanácsi jegyzőkönyvek (MNL W 12)

1872.01.21.

Magyar Nemzeti Levéltár Csongrád Megyei Levéltára, Szentes

- Csanád Vármegye Bizottmányának iratai, IV. B. 252.b. 1871 35.d. 1829-1930.

Magyar Nemzeti Levéltár Csongrád Megyei Levéltára, Szeged (MNL CSMLSZ)

- IV.B. 151. a. Csanád Megye Cs. Kir. Megyehatóságának iratai, 5. k., - 1853. Elnöki Beadványi Jegyzőkönyv.

- IV.B. 151. a. Csanád Megye Cs. Kir. Megyehatóságának iratai, 6. k., - Elnöki Jegyzőkönyv 1854ik évre.

- IV/B. 162. a. Makói Cs. Kir. Szolgabíróság iratai, 6. k., - Csanád Megye Makói Járási Elnöki Jegyző Könyv az 1854iki Közig Évre.

- IV.B. 165. a. Nagylaki cs. kir. Szolgabíróság elnöki iratai 1853, 1854 iktató 2.d. Elnöki Rendeletek Jegyző Könyve Nagy Laki Járás részéről 1854 ik évben 


\section{MELLÉKLET: A VIZSGÁlt VÁRMEGYÉK JÁRÁSI BEOSZTÁSA ${ }^{1116}$}

Köztörvényhatóság

1. Alsó-Fehér vármegye

$\begin{array}{rcr}\text { 1. } & \text { Alvinczi } & 15132 \\ \text { 2. } & \text { Balásfalvi } & 15717 \\ \text { 3. } & \text { Csombordi } & 11689 \\ \text { 4. } & \text { Gyulafehérvári } & 14966 \\ \text { 5. } & \text { Kis enyedi } & 13728 \\ \text { 6. } & \text { Magyar-igeni } & 16703 \\ \text { 7. } & \text { Maros-ujvári } & 13296 \\ \text { 8. } & \text { Nagy-enyedi } & 19054 \\ \text { 9. } & \text { Pokafalvi } & 13390 \\ \text { 10. } & \text { Szentbenedeki } & 8786 \\ \text { 11. } & \text { Topánfalvi } & 27645 \\ \text { 12. } & \text { Verespataki } & 22174 \\ \text { 13. } & \text { Zalathnai } & 13007\end{array}$

2. Arad vármegye

$\begin{array}{rcc}\text { 1. } & \text { Agrisi } & 19828 \\ \text { 2. } & \text { Aradi } & 20475 \\ \text { 3. } & \text { Borosjenői } & 30834 \\ 4 . & \text { Borossebesi } & 17579 \\ \text { 5. } & \text { Butyini } & 20813 \\ 6 . & \text { Eleki } & 22941 \\ 7 . & \text { Kisjenői } & 39182 \\ 8 . & \text { Pécskai } & 24134 \\ 9 . & \text { Radnai } & 21240 \\ \text { 10. } & \text { Soborsini } & 18796 \\ 11 . & \text { Világosi } & 36053\end{array}$

1116 Magyar Nemzeti Levéltár Országos Levéltára, Belügyminisztérium, Általános iratok 117. csomó és 118. csomó. Kimutatva az egyes törvényhatóságok által felterjesztett tervezetekből. A hiányzó adatok a levéltári forrás hiányosságából származnak. 
3. Aranyosszék

1.

2.

4. Bars vármegye

5. Békés vármegye

6. Bereg vármegye

1.

2.

3.

4.

5.

6.

1.

2.

3.

4.

5.

.

3.

.

.

.

1. Beregszászi I. szakasz

2. Beregszászi II. szakasz

3.

4.

5. Munkácsi I. szakasz

6. Munkácsi II. szakasz

7.

7. Csanád vármegye

1

2.

3.

4.

8. Csongrád vármegye

$\begin{array}{ll}\text { Felső } & 8901 \\ \text { Alsó } & 9072\end{array}$

30675

25803

39611

11210

17952

38127

52159

28123

30852

34877

25591

19924 16047 29157 22803 28728 22624 19957 33768 35193 16286 10600
1.
Tiszán inneni
2.
Tiszán túli 
9. Doboka vármegye

$\begin{array}{lcr}\text { 1. } & \text { Buzai } & 19598 \\ \text { 2. } & \text { Dobokai } & 18013 \\ \text { 3. } & \text { Egregy-Almási } & 20338 \\ \text { 4. } & \text { Kerlési } & 15663 \\ \text { 5. } & \text { Pánczélcsehi } & 19466 \\ \text { 6. } & \text { Sajói } & 9853\end{array}$

10. Fejér vármegye

$\begin{array}{lcc}\text { 1. } & \text { Bodaiki alsó } & 25395 \\ \text { 2. } & \text { Bodaiki felső } & 22410 \\ \text { 3. } & \text { Csákvári } & 31029 \\ \text { 4. } & \text { Ráczalmási } & 28424 \\ \text { 5. } & \text { Sárkereszturi } & 31510 \\ \text { 6. } & \text { Vaáli } & 34783\end{array}$

11. Felső-Fehér vármegye

$\begin{array}{lcr}\text { 1. } & \text { Bolyai } & 7524 \\ \text { 2. } & \text { Bürkösi } & 9694 \\ \text { 3. } & \text { Hévízi } & 11801 \\ \text { 4. } & \text { Hidvégi } & 12268 \\ \text { 5. } & \text { Keresdi } & 11336 \\ \text { 6. } & \text { Peselneki } & 5450\end{array}$

12. Fogaras vidék

$\begin{array}{lcc}\text { 1. } & \text { Bethleni } & 20284 \\ \text { 2. } & \text { Törcsvári } & 19752 \\ \text { 3. } & \text { Venitzei } & 20109 \\ \text { 4. } & \text { Visti } & 21483\end{array}$

13. Gömör és Kis-Hont t. e. vármegye

$\begin{array}{lcc}\text { 1. } & \text { Nagy Rőczei } & 35820 \\ \text { 2. } & \text { Rimaszombati } & 35239 \\ \text { 3. } & \text { Rimaszécsi } & 33029 \\ \text { 4. } & \text { Rosnyoi } & 36070 \\ \text { 5. } & \text { Tornallyai } & 33290\end{array}$


Köztörvényhatóság

14. Hont vármegye

$\begin{array}{rcr}\text { 1. } & \text { Balogi } & 7160 \\ \text { 2. } & \text { Báti } & 6150 \\ \text { 3. } & \text { Bozóki } & 7038 \\ \text { 4. } & \text { Egegi } & 5930 \\ \text { 5. } & \text { Ipolysági } & 14178 \\ \text { 6. } & \text { Lukanényei } & 7243 \\ \text { 7. } & \text { Nagy Marosi } & 9922 \\ \text { 8. } & \text { Németi } & 6694 \\ \text { 9. } & \text { Palásti } & 6161 \\ \text { 10. } & \text { Szalkai } & 9597 \\ \text { 11. } & \text { Szántói } & 6091 \\ \text { 12. } & \text { Szent-Antali } & 8188\end{array}$

15. Kővár vidék

$\begin{array}{lcc}\text { 1. } & \text { Kisnyiresi } & 12807 \\ \text { 2. } & \text { Nagynyiresi } & 11647 \\ \text { 3. } & \text { Nagysomkuti } & 13602 \\ \text { 4. } & \text { Váádi } & 13688\end{array}$

16. Krassó vármegye

\begin{tabular}{|c|c|c|}
\hline 1. & Bégai & 20011 \\
\hline 2. & Bogsáni & 28532 \\
\hline 3. & Facséti & 23171 \\
\hline 4. & Gornjai & 27554 \\
\hline 5. & Lugosi & 23830 \\
\hline 6. & Marosi & 21106 \\
\hline 7. & Oravitzai & 27554 \\
\hline 8. & Resitzai & 26329 \\
\hline 9. & Szászkai & 37583 \\
\hline 10. & Temesi & 21479 \\
\hline 1. & Tatai & 34399 \\
\hline 2. & Gesztesi & 33145 \\
\hline
\end{tabular}


Köztörvényhatóság

Járás elnevezése

Lakosság

(fo)

3.

Csalóközi

28300

4.

Udvardi

34990

18. Küküllő vármegye

$\begin{array}{lc}\text { 1. } & \text { Balavásári } \\ \text { 2. } & \text { Dicsőszentmártoni } \\ \text { 3. } & \text { Bényei } \\ \text { 4. } & \text { Radnothi }\end{array}$

19. Nagy-Kikinda kerület

$\begin{array}{lcc}\text { 1. } & \text { Mellenczei } & 21856 \\ \text { 2. } & \text { Mokrini } & 13490 \\ \text { 3. } & \text { Nagykikindai } & 26863\end{array}$

20. Nógrád vármegye

$\begin{array}{lcc}\text { 1. } & \text { B. Gyarmati } & 31243 \\ \text { 2. } & \text { Nógrádi } & 28179 \\ \text { 3. } & \text { Szécsényi } & 29379 \\ \text { 4. } & \text { Szarvas Gedei } & 32143 \\ \text { 5. } & \text { Losonczi } & 35601 \\ \text { 6. } & \text { Füleki } & 42257\end{array}$

21. Pozsony vármegye

$\begin{array}{lrc}\text { 1. } & \begin{array}{r}\text { Dunaszerdahelyi (vagy alsó } \\ \text { csallóközi) }\end{array} & 33303 \\ \text { 2. } & \text { Galánthai } & 36647 \\ \text { 3. } & \text { Malaczkai } & 44292 \\ \text { 4. } & \text { Nagy Szombati } & 42088 \\ \text { 5. } & \text { Pozsonyi } & 27594 \\ \text { 6. } & \text { Somorjai } & 24600 \\ \text { 7. } & \text { Szempczi } & 19540\end{array}$

Köztörvényhatóság

Járás elnevezése

Lakosság

(fö)

22. Sáros vármegye

$\begin{array}{lcc}\text { 1. } & \text { Berzeviczei } & 17282 \\ \text { 2. } & \text { Gaboltoi } & 12979\end{array}$


Girálti

11224

4.

Hanusfalvi

10060

5.

Héthársi

15232

6.

Lemesi

15310

7.

Nagy Sárosi

14304

8.

Raszlaviczi

10210

9.

Sóvári

14902

10.

Svidniki

9981

11.

Szinyeujfalui

12559

12.

Zboroi

12281

23. Szabolcs vármegye

$\begin{array}{ccc}\text { 1. } & \text { Dadai alsó } & 27390 \\ \text { 2. } & \text { Dadai felső } & 19970 \\ \text { 3. } & \text { Dadai közép } & 23547 \\ \text { 4. } & \text { Kisvárdai alsó } & 26930 \\ \text { 5. } & \text { Kisvárdai felső } & 19873 \\ \text { 6. } & \text { Nádudvari alsó } & 32851 \\ \text { 7. } & \text { Nádudvari felsö } & 20430 \\ \text { 8. } & \text { Nádudvari közép } & 25431 \\ \text { 9. } & \text { Nyírbáthori alsó } & 24572 \\ \text { 10. } & \text { Nyírbáthori felső } & 22724\end{array}$

24. Szepes vármegye

$\begin{array}{lcc}\text { 1. } & \text { Bányai } & 25542 \\ \text { 2. } & \text { Lőcsei } & 20954 \\ \text { 3. } & \text { Hernádvölgyi } & 22961 \\ \text { 4. } & \text { Magurai } & 21252 \\ \text { 5. } & \text { Poprádvölgyi } & 24054 \\ \text { 6. } & \text { Tárnai } & 19498\end{array}$

25. Temes vármegye

1. Temesvári vagy központi

2. Uj aradi

3. Vingai

4. Lippai 
5.

Rékási

6.

Buziási

7.

Csakovári

8.

Dettai

9.

Versetzi

26. Trencsén vármegye

$\begin{array}{lcl}\text { 1. } & \text { Baáni } & 23022 \\ \text { 2. } & \text { Csaczai } & 31300 \\ \text { 3. } & \text { Illovai } & 25806 \\ \text { 4. } & \text { Kiszucz Ujhelyi } & 25584 \\ \text { 5. } & \text { Nagy Bitsei } & 28662 \\ \text { 6. } & \text { Puchói } & 25328 \\ \text { 7. } & \text { Trencséni } & 30816 \\ \text { 8. } & \text { Vág-Beszterczei } & 24849 \\ \text { 9. } & \text { Zsolnai } & 37228\end{array}$

27. Veszprém megye

$\begin{array}{lcc}\text { 1. } & \text { Veszprémi } & 46295 \\ \text { 2. } & \text { Pápai } & 53132 \\ \text { 3. } & \text { Devecseri } & 37267 \\ \text { 4. } & \text { Zirczi } & 38525 \\ \text { 5. } & \text { Enyingi } & 26212\end{array}$

28. Zala vármegye

$\begin{array}{rcc}\text { 1. } & \text { Baksai } & 12421 \\ \text { 2. } & \text { Csáktornyai } & 29853 \\ \text { 3. } & \text { Kanizsai } & 41503 \\ \text { 4. } & \text { Keszthelyi } & 23273 \\ \text { 5. } & \text { Lendvai } & 32627 \\ 6 . & \text { Letenyei } & 16495 \\ 7 . & \text { Pacsai } & 22431 \\ \text { 8. } & \text { Perlaki } & 35167 \\ 9 . & \text { Sümegi } & 24318 \\ \text { 10. } & \text { Szt. Grothi } & 16859\end{array}$


Köztörvényhatóság

Járás elnevezése

11.

12.

29. Zaránd vármegye

$\begin{array}{lcc} & \text { Járás elnevezése } & \begin{array}{c}\text { Lakosság } \\ (\text { fö) }\end{array} \\ \text { 11. } & \text { Tapolczai } & 40980 \\ \text { 12. } & \text { Zalaegerszegi } & 36462\end{array}$

1. Nagyhalmágyi 14423

2. Körösbányai 15649

3. Brádi 25550 